\title{
y y y y
}

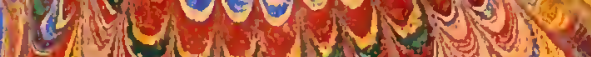



22102056500
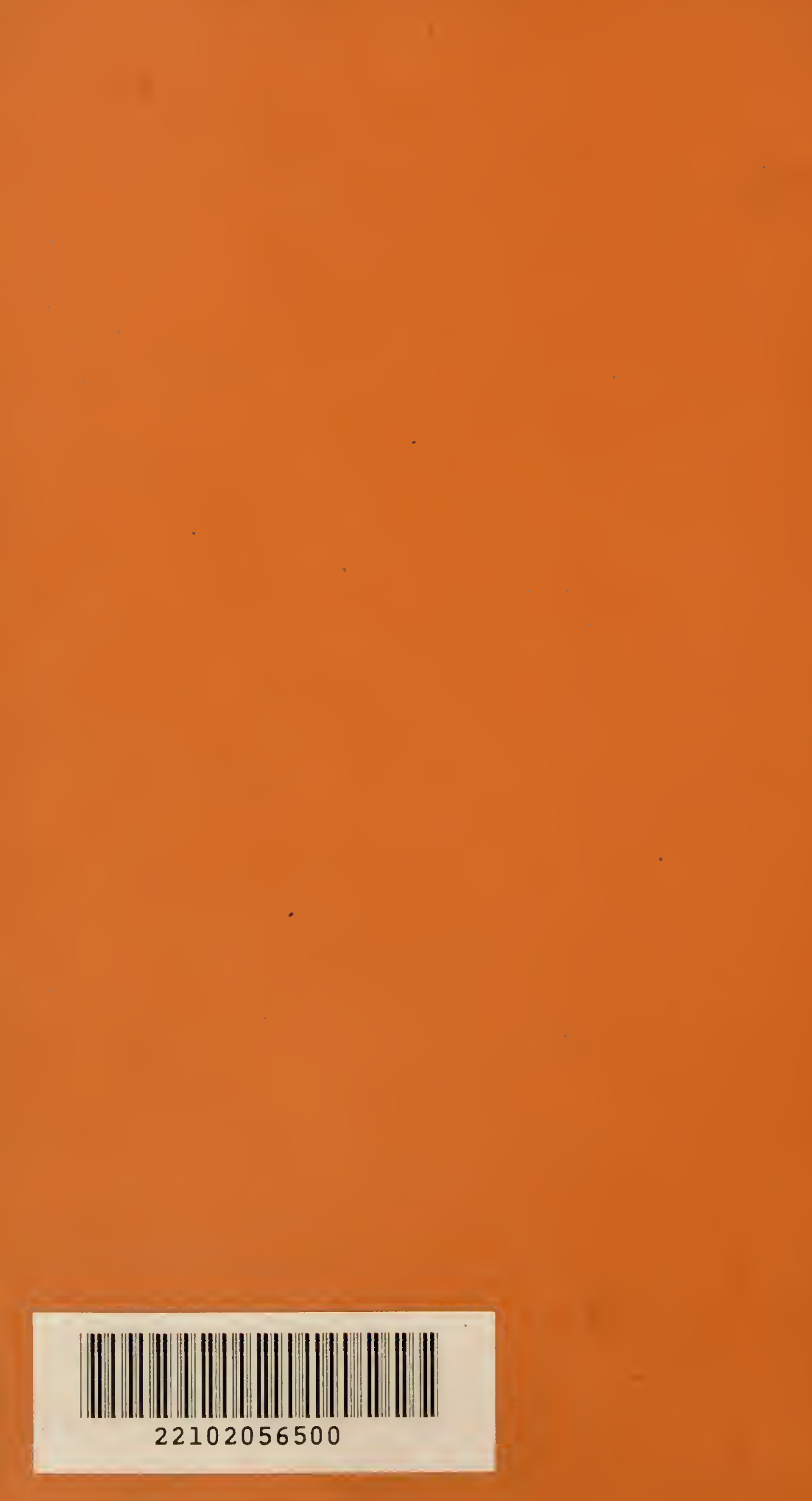


$$
\begin{gathered}
\text { Med } \\
\text { K5056 }
\end{gathered}
$$








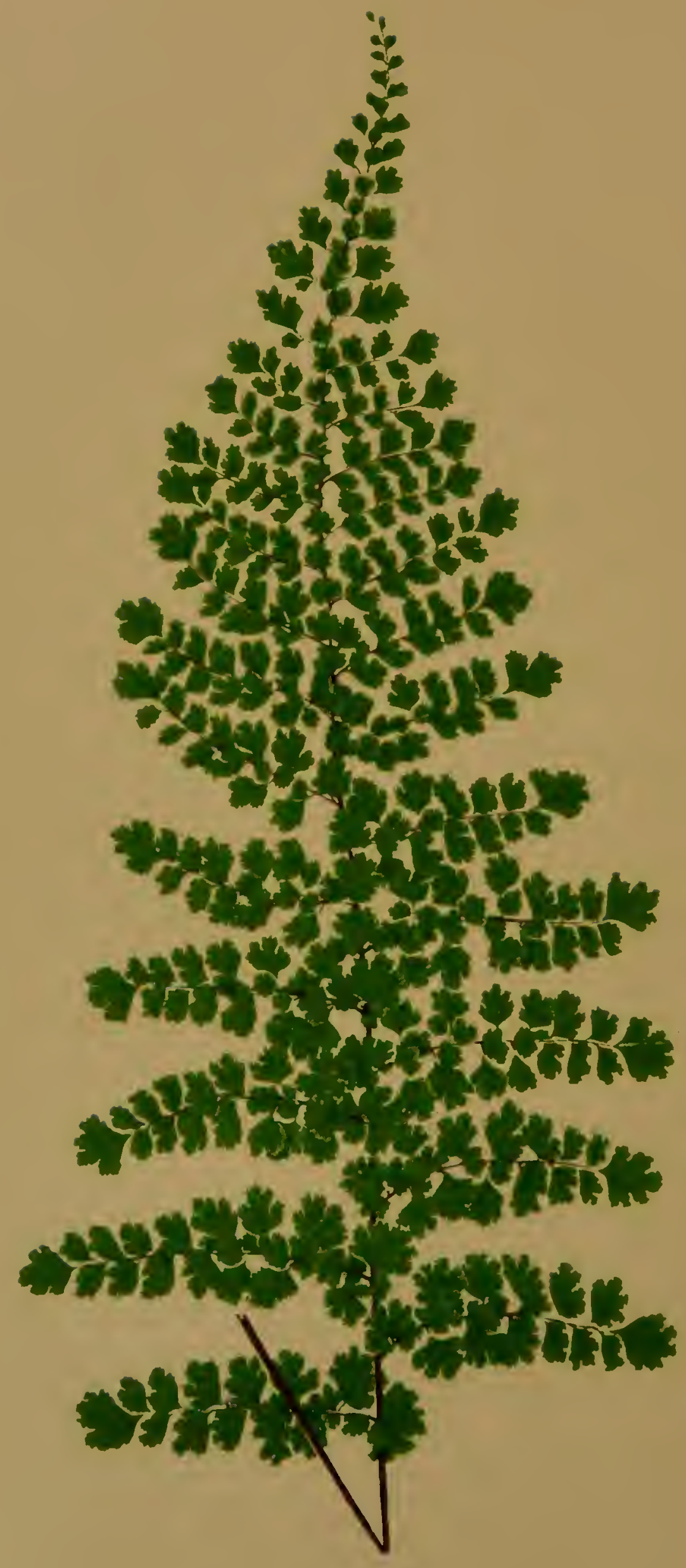




\title{
F E R N S:
}

\section{BRITISH AND EXOTIC.}

\author{
VOL U M E III.
}

COXTAINIXG
A D I A N T UM.
ON Y CHIUM.
PLATYLOMA.
A LLOSORUS.
DOR Y OP'L'ERIS.
PTERIS, IN PART.

$\mathrm{BY}$

E. J. LOWE, ESQ., F.R.A.S., F.G.S., F.L.S., F.Z.S., M.B.M.S.,

Iron. Mem. Dublin Nat. IIist. Soc., Mem. Geolog. Soc. Edin.,

Corr. Nem. Iyceum Nitt. IIist., New York, Corr. Mem. Manchester Lit. and Plil. Soc., ete.

\section{L, O N D O N :}

GROOMBRTDGE AND SONS, 5, PATERNOSTER ROW. M DCCC LXIV. 

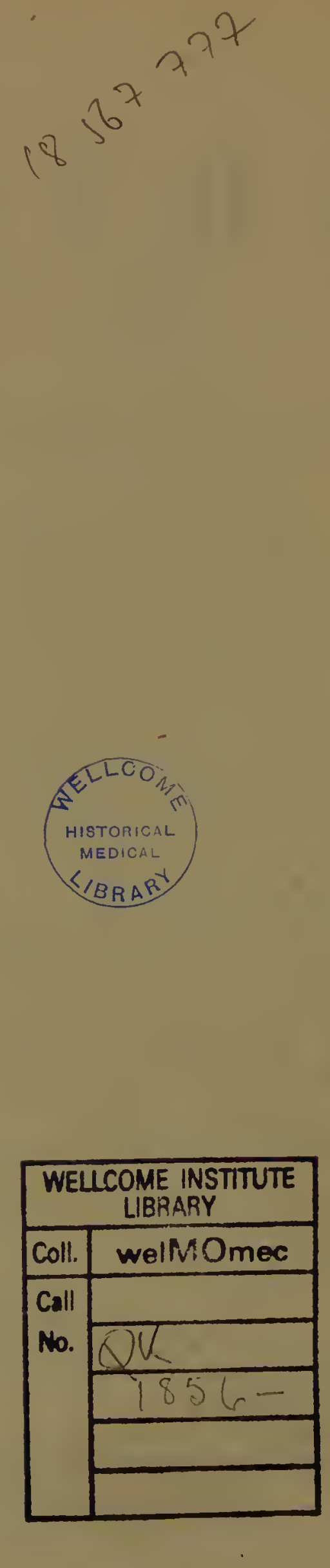


\section{CONTENTS OF VOL. III.}

\begin{tabular}{|c|c|c|c|c|c|c|c|}
\hline \multirow[b]{2}{*}{ Adiantum affine } & \multicolumn{3}{|c|}{ Plate. Page. } & & \multicolumn{3}{|c|}{ Plate. Page. } \\
\hline & & vii & 19 & Platyloma atropurpur & & $\operatorname{xx} A$ & 81 \\
\hline assimile & & viii $A$ & 21 & brownii. & & xsix & 79 \\
\hline capillus-veneris & & $\mathrm{xV}$ & 39 & calomelanos & & xxvi & 73 \\
\hline caudatum & & ii ${ }_{A}$ & 5 & falcata. & & $x \times x$ B & 83 \\
\hline concinnum . & . & i & 3 & flexuosa . & & $X X V$ & 71 \\
\hline cristatum & & xxii & 55 & geraniifolia & & xxvii & 75 \\
\hline cultratum & . & $x x i$ & 53 & hastata & & xxxii & 87 \\
\hline cuneatum & & $\mathbf{v}$ & 15 & intramarginalis & & xxxi & 85 \\
\hline cunninghami & . & xii & 31 & rotundifolia & & $\operatorname{xxiv} A$ & 67 \\
\hline curvatum & & $\mathrm{vi}$ & 17 & sagittata & & xxviii & 77 \\
\hline formosum & & xi & 29 & ternifolia & & $\operatorname{xxiv} B$ & 69 \\
\hline fulvum . & & xix & 49 & Allosorus crispus & & xxxiv & 93 \\
\hline hispidulum & - & xiii $\wedge$ & 33 & Doryopteris collina & & xxxviii & 105 \\
\hline intermcdium & & $\mathrm{xx}$ & 51 & palmata & & sxxvii & 103 \\
\hline lucidum & . & iv $A$ & 11 & pedata & . & $\mathrm{xxxy}$ & 99 \\
\hline lunulatum . & & viii $\mathrm{B}$ & 23 & sagittxfolia & & $x x x v i$ & 101 \\
\hline macrophyllum & . & iv $B$ & 13 & Pteris arguta & . & xli & 115 \\
\hline obliquum . & & xiii $\mathrm{B}$ & 35 & biaurita & & . 1 & 133 \\
\hline pedatum . & & xiv & 37 & crenata & . & xlviii & 129 \\
\hline pubescens & & $\mathrm{ix}$ & 25 & cretica & & xliii & 119 \\
\hline pulrerulentum & . & xvii & 45 & grandifolia & & xlix & 131 \\
\hline reniforme & & ii $\mathrm{B}$ & 7 & kingiana & & $x \operatorname{li}$ & 125 \\
\hline tencrum & & $x$ & 27 & leptophylla & & slvii & 127 \\
\hline trapeziforme & & iii & 9 & longifolia & & xlii & 117 \\
\hline varium & • & xviii & 47 & scrrulata. & . & $x]$ & 113 \\
\hline wilsoni . . & & xvi & 43 & tremula & & xlv & 123 \\
\hline Onychium lucidun & & xxiii & 63 & umbrosa & & dxxix & 111 \\
\hline Mlatylom a adiantoides & & xxxiii & 89 & vespertilionis & & xliv & 121 \\
\hline
\end{tabular}





\section{F E R N S;}

\section{BRITISH AND EXOTIC.}

\section{P'TERIDE ÆE. J. SuIth.}

'THIs extensive class of Ferns contains the genus Hypolepis, species with large and handsome fronds; the genus Cheilanthes, a very pretty tribe of plants, some of which are covered beneath the frond with dense farinose powder; Platyloma, a very varied and handsome tribe; Adiantum, known generally as the Maiden-hair Ferns, the most clelicate-looking of any tribe; Litobrochia, an extensive genus; Pteris, mostly large and elegant Ferns; Onychium, a small but interesting family; Lomaria, having fertile fronds, different in form from the barren fronds; Blechnum and Doodia, singular Ferns; and Woodwardia, a small but elegant genus.

In the Pteridea the sori are circular or elongated, and transversc, marginal, intramarginal, or costal, simple, except when they become confluent, when they are compound. The sori have a special lateral indusium, which is produced on the exterior side of the sporangifcrous rcceptacle. Its inner margin is free.

'The Pteridece are at once known from the Polyportiacee by the special inclusium. 


\section{GENUS I.}

\section{AIIANTUM. LINNeUs. J. SMith.}

The fronds of the genus Adiantum have a curious property of repelling moisture, henee its name, Adiantos meaning dry. The form of the sori is reniform, oblong, round, or linear; they are plaeed on the margin of the pinna, either in a eontinuous line or interrupted. The venules are direet, their apiees terminating in the axis of the indusium. The indusium is venose, being formed of a reflexed erenule, of an oblong linear or reniform shape, aceording as the margin of the frond is erenulate, or more or less entire. The indusium on the under side is sporangiferous, after a time becoming replieate.

'The midrib of the pinnæ eecentrie or wanting.

The veins are unilateral or radiating, and are forked.

The form of the frond is either simple, pinnate, pedate, bipinnate, reniform, or deeompound; varying in its length from six inches to ihree feet. The fronds are mostly smooth.

The stipes and raehis are mostly blaek in colour, and have a polished glossy appearanee. Usually the pinnæ are oblique, truncate, or wedge-shaped at the base, or dimidiate, and only soriferous on the upper margin, mostly articulated with the rachis or petiole.

Sir William Hooker, in his splendid work, "Specics Filieum," has described no less than one hundred and eight speeies of this lovely tribe of plants; many of them, however, are unknown as eultivated plants.

The minjority of the Adiantums are natives of tropieal or teniperate climates. 


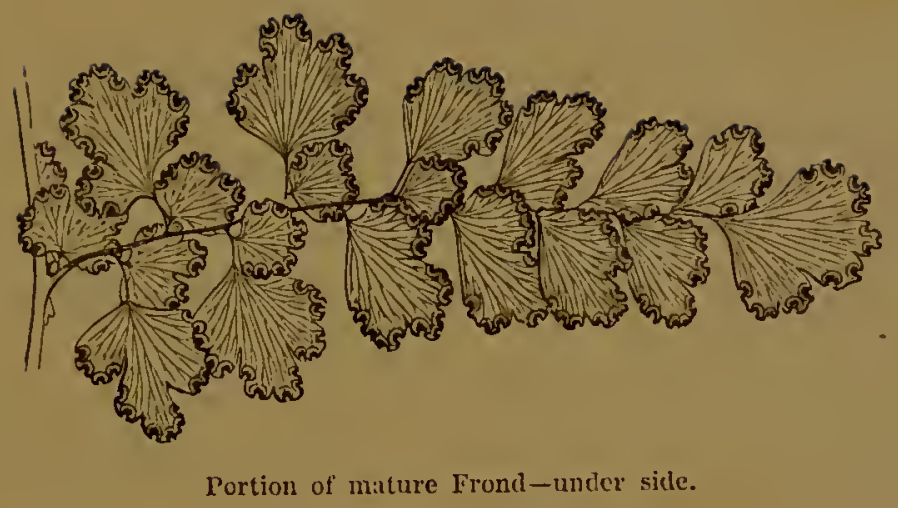

\section{ADIANTUM CONCINNUM.}

\section{Hóner. Humboldt. Presl. Bonpland. Link.}

\section{Willdenow. Moore and Houlston. Kuntil.}

PI.ATE I. VOL. III.

\section{Adiantum tenerum, \\ " affine, \\ " cureatum,}

Adiantum-Dry. Concinnum-Neat.
ScHKUחR.

Matrtens and Galleotti.

HoorER.

Tins very lovely pendulous spccies is not common in cultivation, being only found in the more completc collections of Ferns. It is descrving of a place in every Fern-house. The frond is scmi-transparent, and the sori being numerous, are shown to grcat advantagc.

It is a widely-spread Fern, bcing a native of the Wcst Indies, Central and South America, Caraccas, Guayaquil, Chacapoyas, Peru, Mexico, Gallipagos, Jamaica, St. Vinccnt Island, Tenezuela, and the Andes of Quito.

It is an evergrcen stove species. 
'The length of the frond raries from one to two fect, and about cight inches broad in the widest part.

Tripinnate, glabrous, slender, membranaccous, the pinnules being rhomboidal and obliquely wedge-shaped at the base; the lobes crenate, blunt, and mostly entire. The lowest pinnulcs of each primary and secondary pinna are upright, and appressed to the rachis.

Sori small, about eight to ten in number on each pinnule; the indusium reniform.

The stipes somewhat short, the main rachis straight and thick; stipes and rachis g]abrous, shining, and ebeneous; when young, green. Fronds of about an equal width for two-thirds of their length, then gradually tapering to the apcx, lateral, attached to a somcwhat creeping rhizoma.

It requires to be cultivated in a store, indeed all the Adiantums flourish best in heat, even the hardy species. 'The British Adiantum capillus-veneris, and the North American A. pedatum, although both flourish in the open air in this clinatc, will grow so much more luxuriantly in a store, that an ordinary Fern grower is astonished at the increascd size and healthy appearance of these species.

A. concinnum requires shade.

It appears to be in most of the Nurserymen's Catalogues, as it is in those of Messrs. Veitch, of Exeter; Rollisson, of Tooting; E. G. Henderson; A. Henderson; Backhouse, of York; and Booth and Son, of Hamburg.

Messrs. Backhouse, of Tork, have sent me a plant of this Fern; and Mrr. Henderson, of Wentworth, and Mr. Normun, of Hull, have forwarded fructified fronds.

The illustration is from a plant in my own collection. 



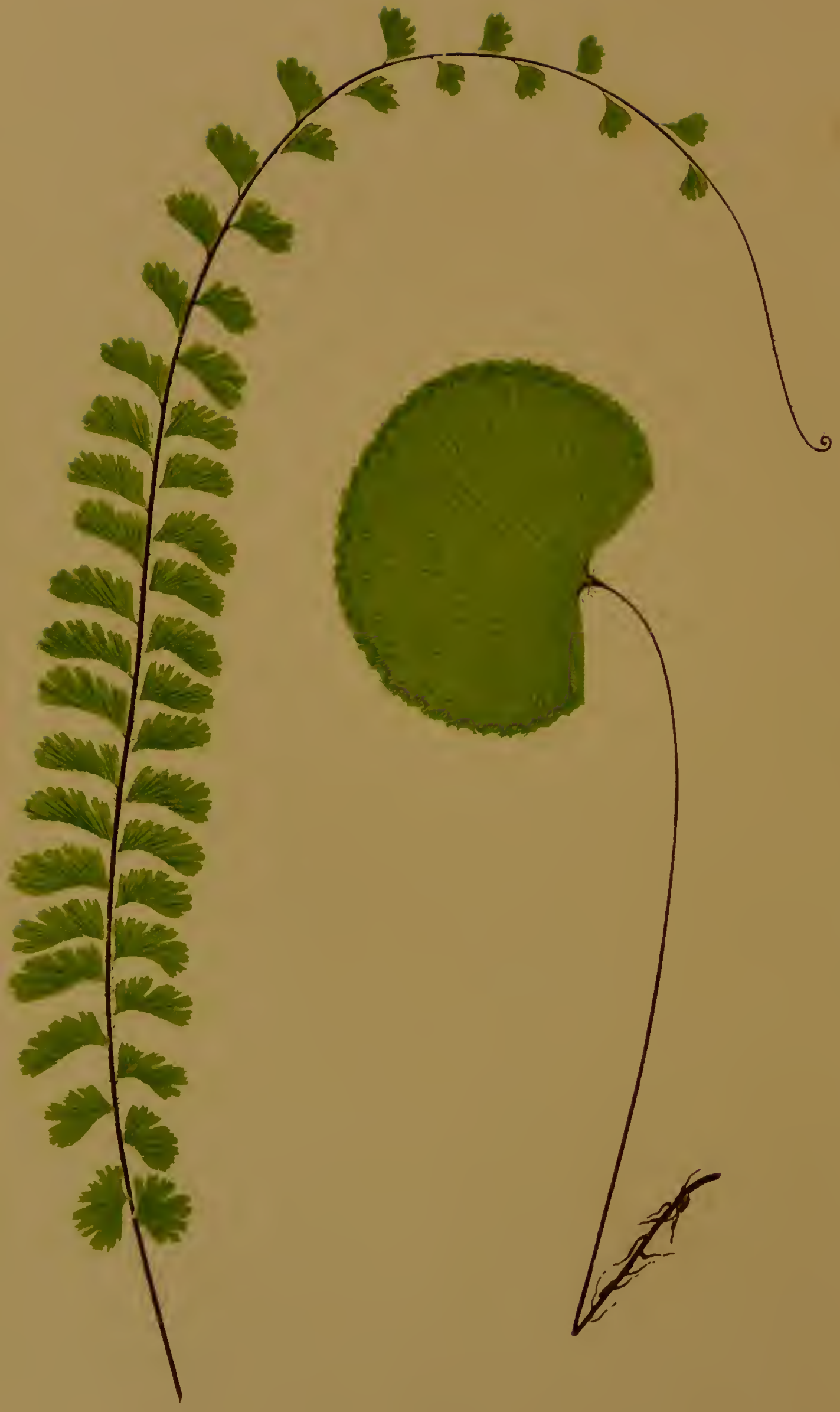






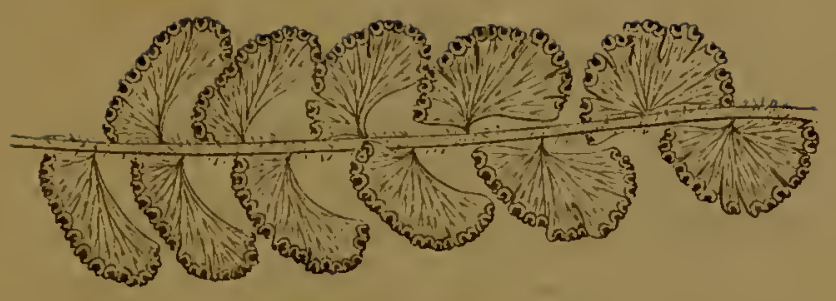

Portion of miture Frond under sile.

\section{ADIANTUM CAUDATUM.}

\section{Linneus. MoOre and IIoulston. Hooker. Fre. \\ Burahnn. P'resl. Kallfuss. Sphexgle. Sitatt. SCHKUHR. WILLDENOW.}

PLATE II.-A. VOL. III.

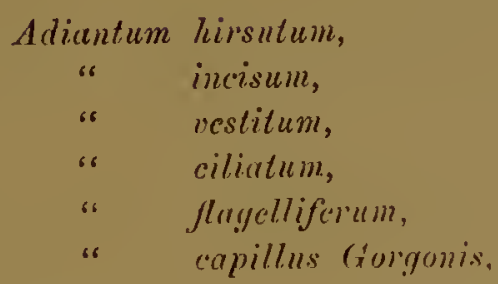

Adiantum-Dry.
BORY. WILLDENOW.

Foliskitil.

Wirucir.

Bi.c.Me.

WALLICH.

WrEB

Ax evergrecn stove species, very different in appearance to the majority of the Maiden-hair Ferns.

'The usual length of the frond is from twelve to cightecn inches; in form it is clongated, attenuatcel, hairy, not unfrequently rooting at the apex; the pimme oblong-obtuse, being wedge-shaped at the base; the upper margin separated into small dilatate segments. Pinnac rather thick, membrinaccous. the veins mostly prominent and well secen.

VOL. III. 
Rachis and stipes pale brown, devoid of pinnx at the apex, terminal, rising out of a faseieulate rhizoma, elothed with ehaffy fulvous hairs. The stipes short and tolcrably stout.

'The eolour of the frond pale dull green.

Sori numerous, small, one on each segment; involueres nearly orbieular.

A widely-spread Fern, from China, Ceylon, Mauritius, Manilla, Malay Islands, Java, Arabia-Felix, Cape de Verde Islands, Madras, Bengal, Nepal, Behar, Assam, Boutan, Mishmee Mountains, ete.

It requires eonsiderable heat to grow it luxuriantly.

Mr. Henderson, of Wentworth, has kindly forwarded a plant of this speeies.

Adiantum caudatum is eontained in the Catalogues of $\mathrm{Mr}$. R. Sim, of the Nursery, Foot's Cray; Mr. E. Cooling, of Derby; and of Messrs. Booth, of Hamburg.

The frond illustrated was sent by Mr. Henderson, of Wentworth. 


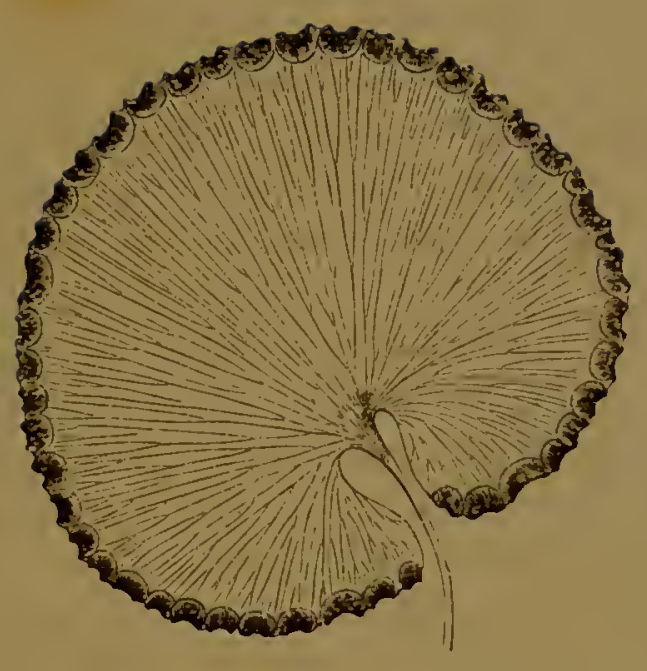

Portion of mature Frond-under side.

\section{ADIANTUM RENIFORME.}

Linnaus. J. Smith. Hooker. Moore and Holliston.

Siwartz. Fee. Sprengel. Schiohr. Kaulfuss.

Kunze. Willdenow. Link.

PLATE II.-B. VOL. III.

Adiantum-Dry. Reniforme-Kidney-shaped.

As interesting and very distinct species, differing from all other Ferns in this genus, in habit and form of frond, excepting Adiantum asarifolium; and some authors consider this identical with $A$. reniforme. Howcver, Sir William Hookcr thinks differently; remarking that $A$. reniforme is morc slender, has long stipes, is less scaly, the frond smaller and of thinner texture, and having less densely-approximated involucres. $A$. usarifolium is always a stouter and coarser plant. Willdenow also considers the two plints distinct. Both of these species 
have a very limited gengraphical range; $A$. reniforme being confined to Naderial, Teneriffe, and the $\Lambda$ zores; and $A$. asurifolium to the Mauritius and the Island of Bourbon. P'etiver describes a third very similar plant, said to have been foumd in the Philippine Islands, and which he has ealled A. Plitippense. Other botanists having failed in their scarch for Petiver's Fern, I fear that it must be considered as a doubtful plant.

'The frond is simple, glabrous, and reniform, that is, kidneyshaped, having a broad shallow sinus; in length it is about six inches, and in width usually two inches; terminal, rising out of a sealy and somewhat erecping rhizoma. The colour of the frond a brilliant shining green.

Sori oblong and contiguous.

An evergreen grecnhouse species, requiring attention in its cultivation.

I am indebted to Mr. Sim, of Foot's Cray, for a plant of this Fern; and to Mr. Sim; Mr. Norman; Messrs. Booth; and Mr. Henderson, of Wentworth, for fructificd fronds.

It is in the Catalogues of Messrs. A. Henderson, of Pineapple Place; E. G. Henderson, of St. John's Wood; Backlouse, of York; Rollisson, of Tooting; Sim, of Foot's Cray; Parker, of the Paradise Nursery, Holloway; and Booth, of Hamburg. It is not a common Fern, being found only in the more complete British collections.

The illustration is taken from a frond forwarded by Mr. Sim, of the Foot's Cray Nursery. 



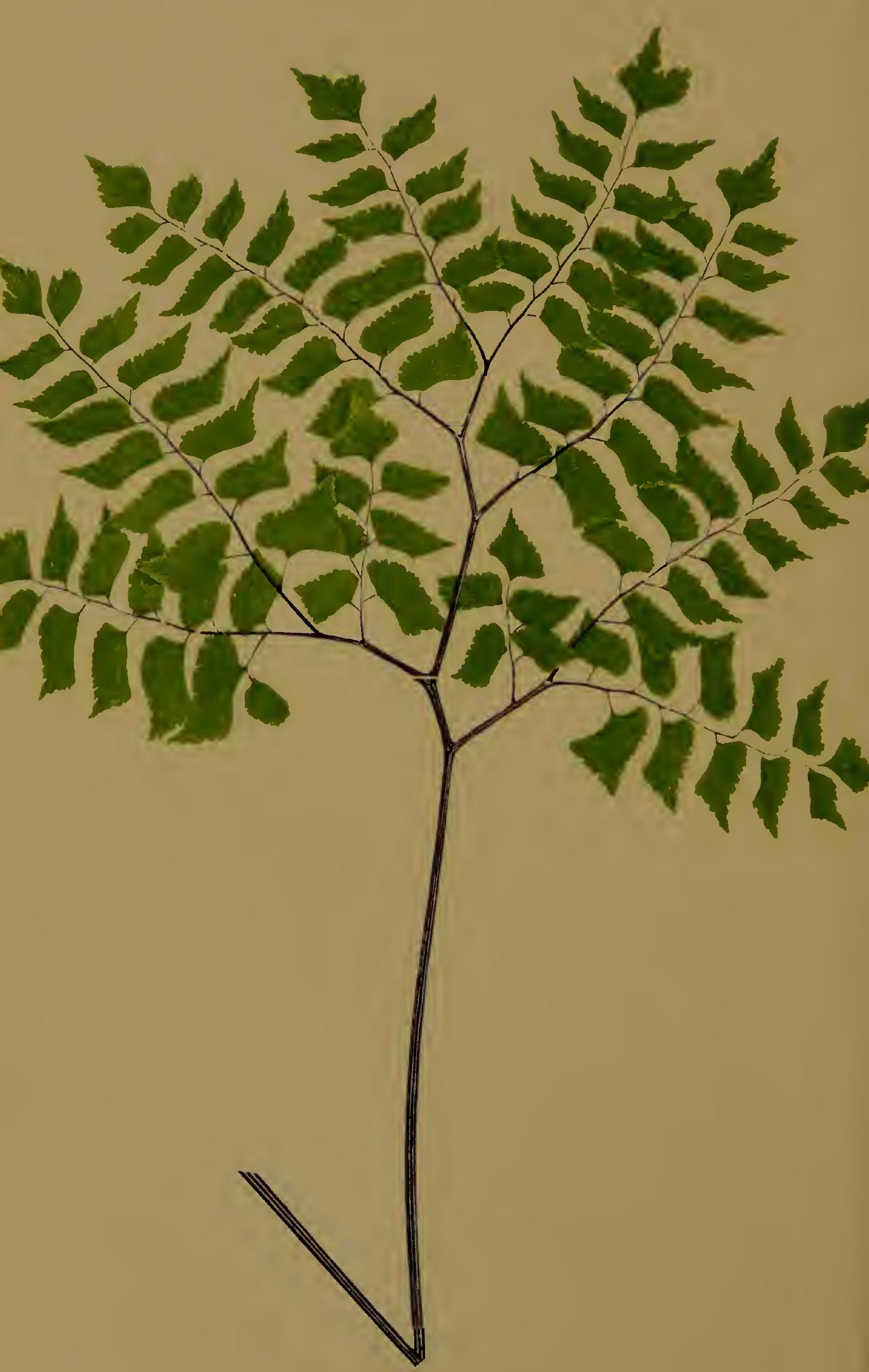






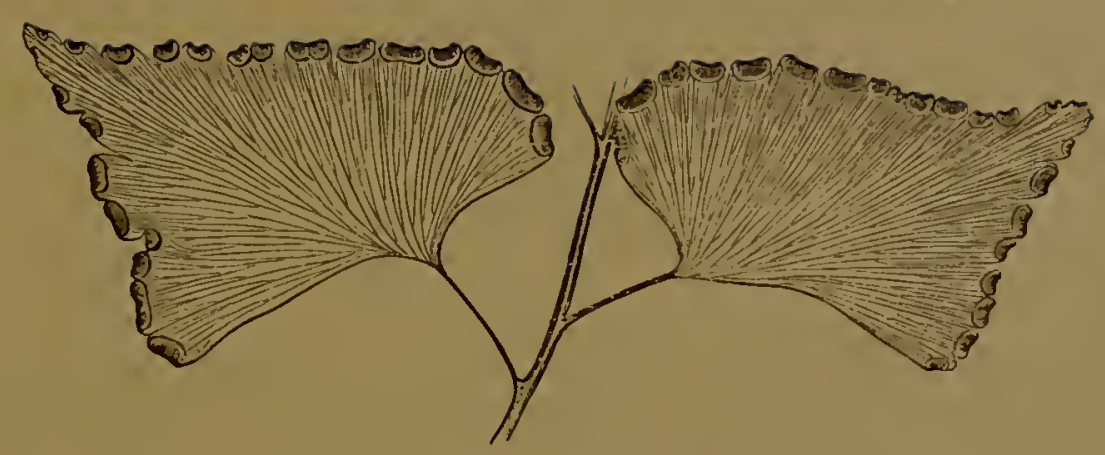

Portion of mature Frond-under side.

\section{ADIANTUM TRAPEZIFORME.}

Linnæus. Hooker. Fee. Shartz. Willdenow. Link. Moore and Houlston. Kunze. J. Smith. Presl. Linden. Galleotti. Seeman. Skinner.

PLATE III. VOL. III.

\begin{tabular}{|c|c|c|}
\hline Adiantum & cminens, & Prest. \\
\hline “ & Klotzschianum, & Prest. \\
\hline “ & formosissimum, & Klotzsch. Plomier. \\
\hline " & pentadactylon, & LangsdorfF and Fischer. \\
\hline " & & Hooker and Greville. \\
\hline "6 & rhomboideum, & Scпкипв. \\
\hline
\end{tabular}

Adiantum-Dry. Trapcziforme-Rhomb-shaped leaves.

Trrs delicate, yet bold-looking specics is well known to all the principal Fcrn cultivators, but is seldom to be found in small collections. Easily cultivated, and when grown as a large specimen this Fern becomes so attractive an object, that it seems desirable that it should be added to every collection.

An evergreen stove Fern.

VOL. III. 
Four times pinnate, the pinnules being large and of a brilliant green colour; in form the fronds are ovate-rhomboidal, acuminate, having the apex serrate and subcrenate.

The length of the frond varies from two to four fect.

The stipes, rachis, and pedicels, ebeneous and densely black; near the base are a fer thin scales.

Fronds lateral, and attached to a short creeping rhizoma; glabrous.

Sori large, oblong, prominent, with reniform indusium.

Adiantum trapeziforme is a native of the West Indian Islands -Jamaica, Cuba, Mexico, Central Ameriea, Caraceas, Brazil, Vera Cruz, and Guatemala.

My thanks are due to Messrs. Backhouse, of York; and to Mr. Ingram, gardener to Earl Brownlow, (Belton,) for plants of this species.

It is in the Catalogues of Messrs. Backhouse, of York; Rollisson, of Tooting; Booth and Son, of Hamburg; Veitch, of Excter; Sim, of Foot's Cray; A. Henderson, of Pine-apple Place; and Masters, of Canterbury.

The illustration is from a frond sent by Mr. Henderson, of Wentworth. 



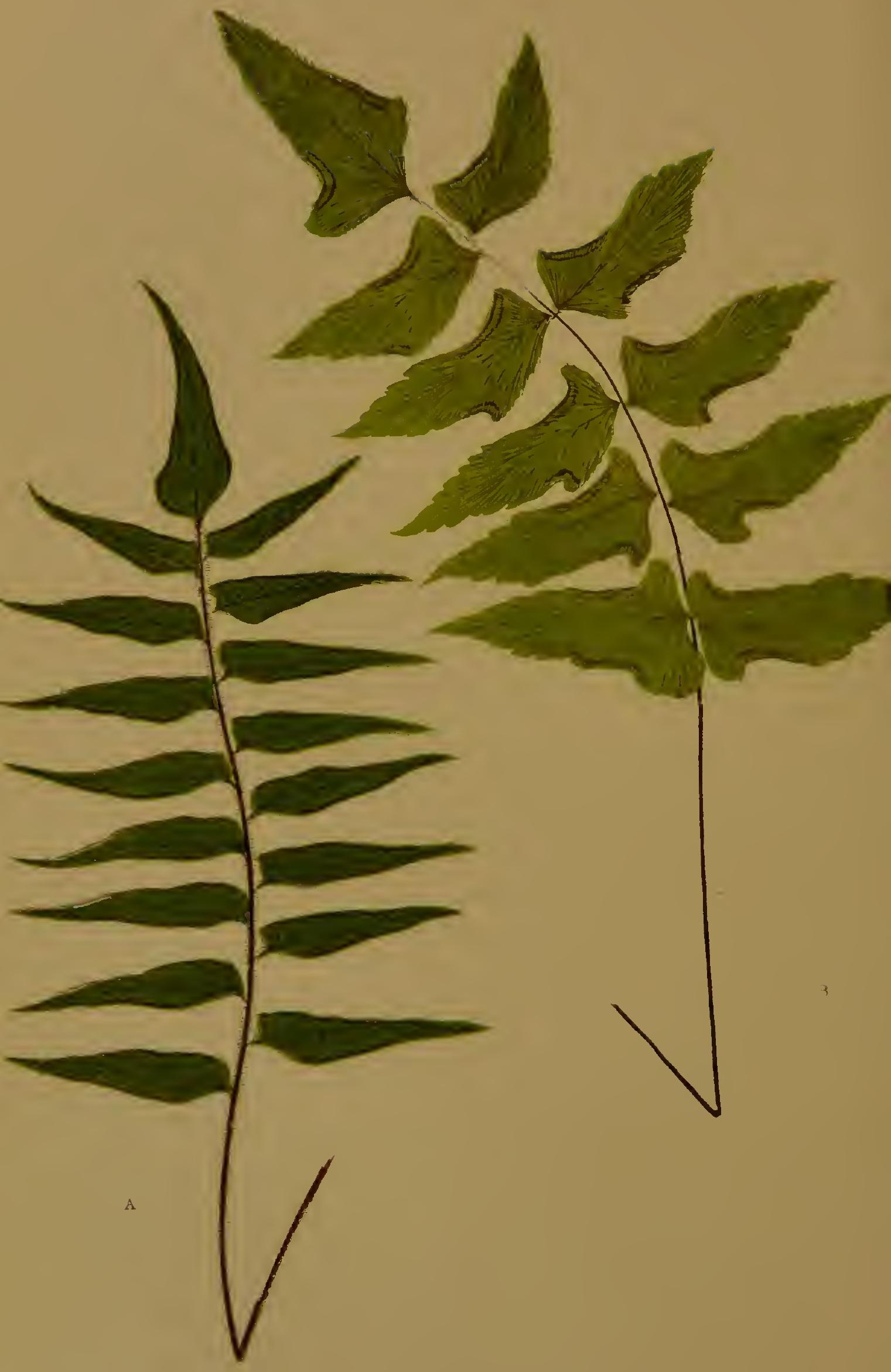




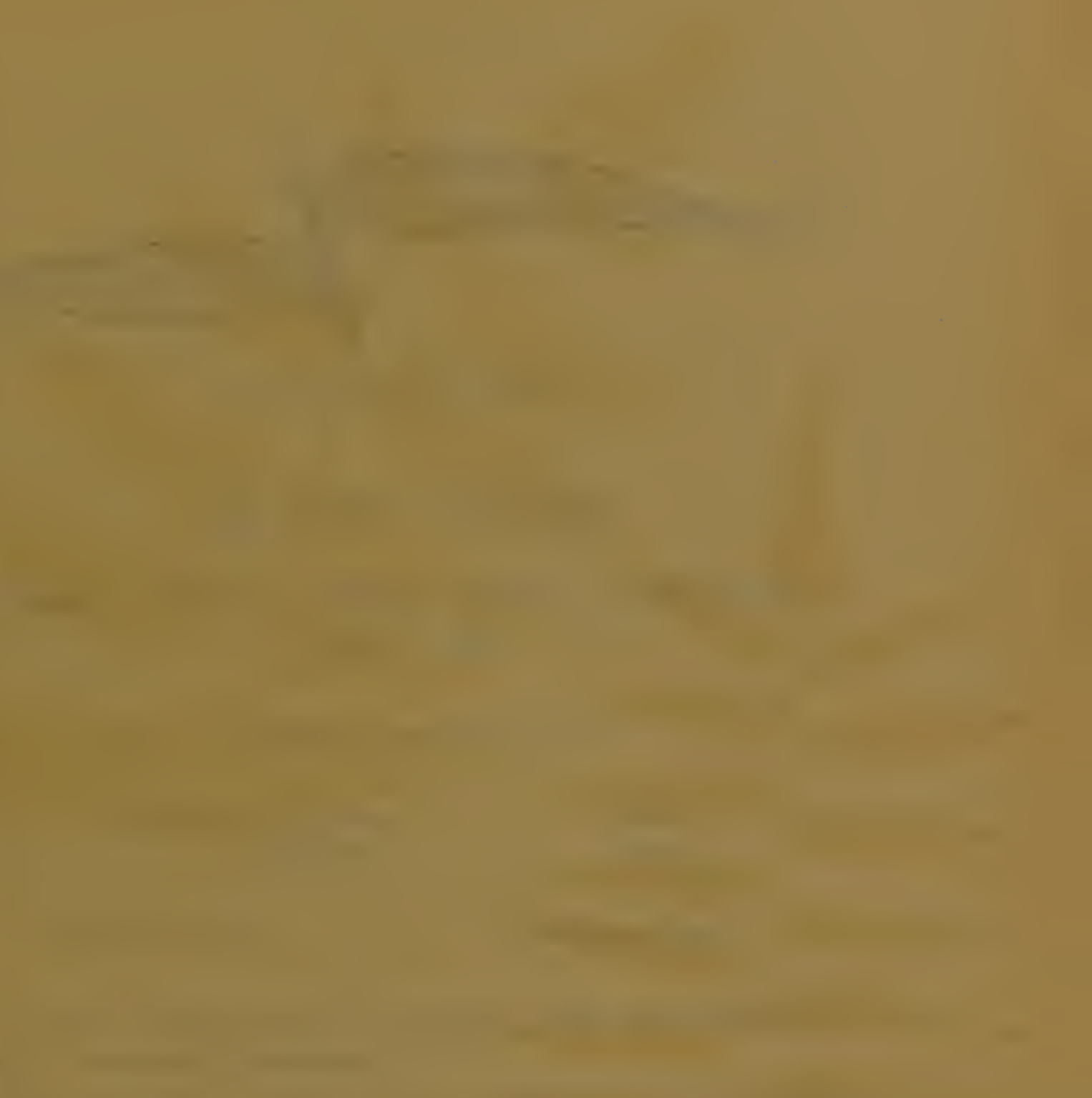

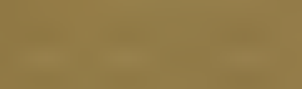

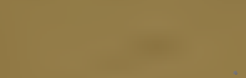
and

$=1+1$

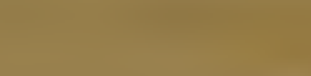

$x^{2}=-1$

$-2=$

I

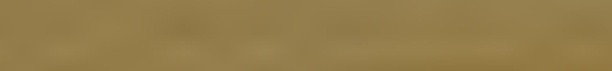

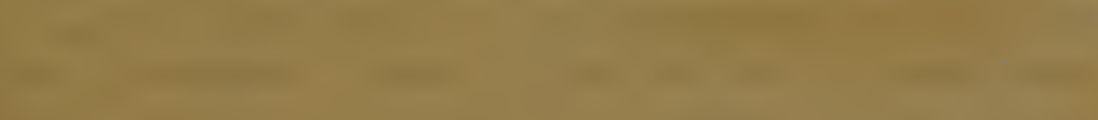

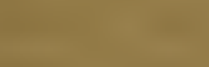

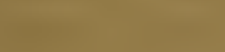

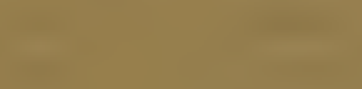
(1) 1 int

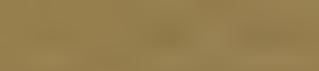
$1+\frac{1}{1+2}$
든

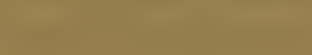

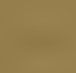
둔

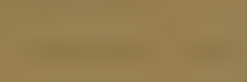
16.

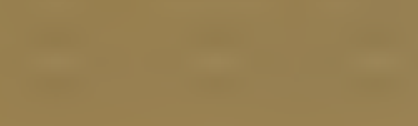

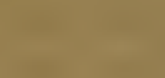
$1+1$

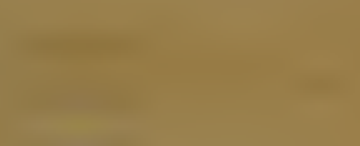

$x_{-i}=$ 

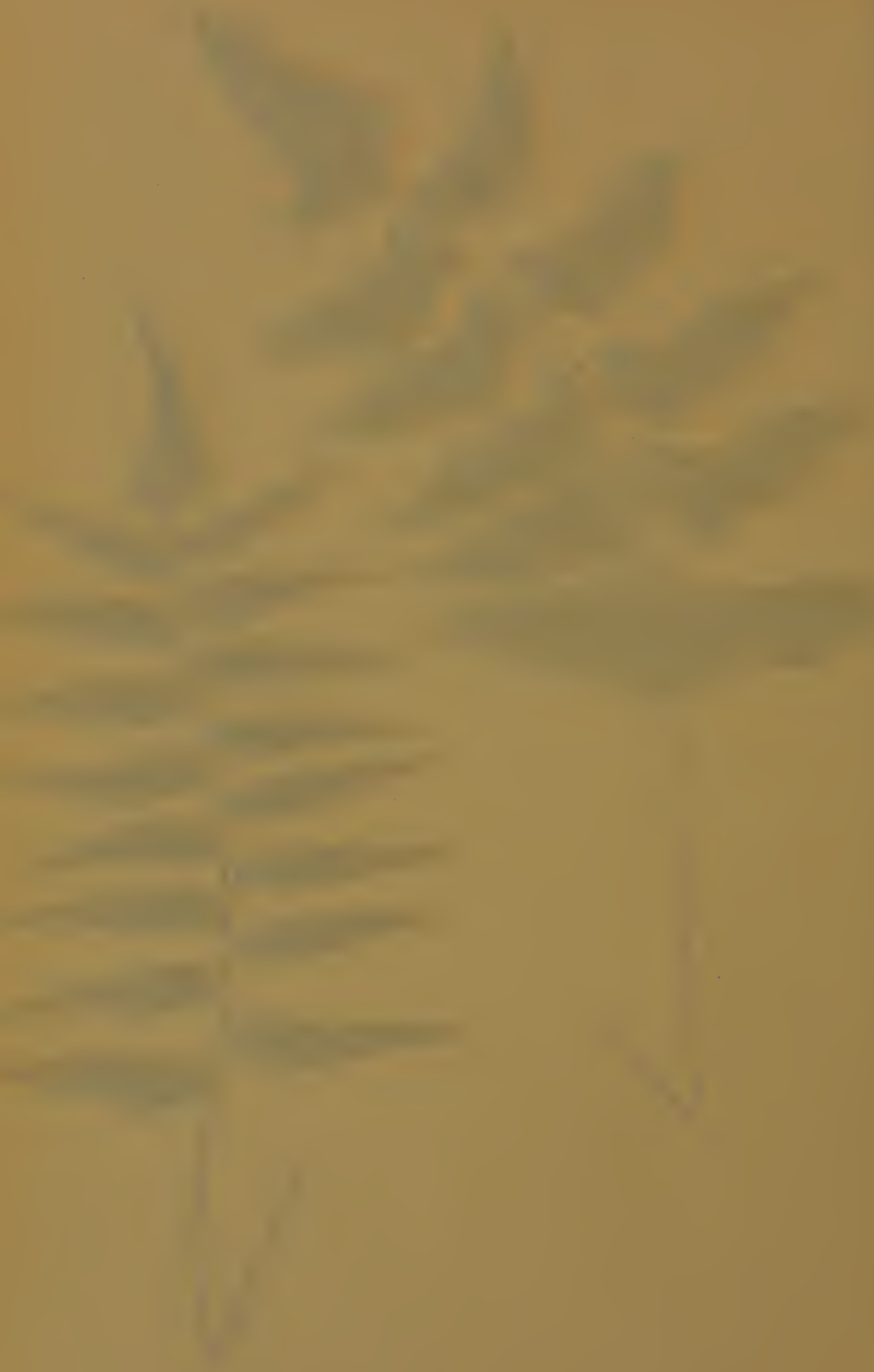


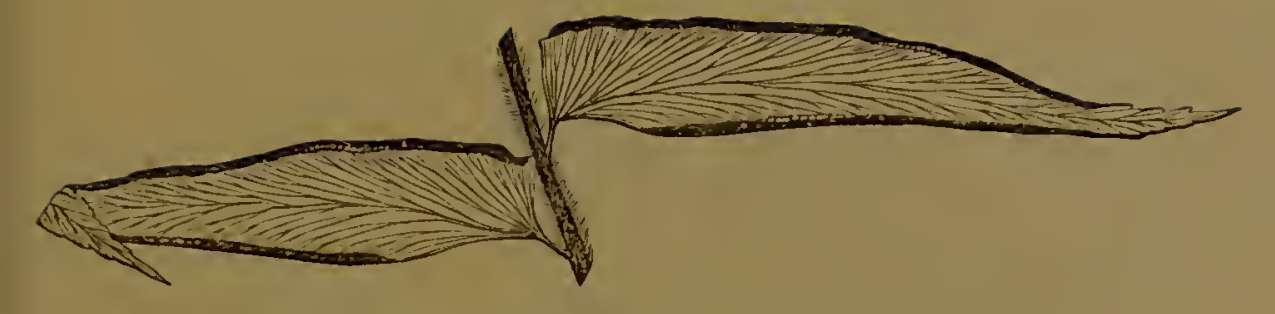

Portion of mature Frond-under side.

\section{ADIANTUM LUCIDUM.}

\section{Hooker. Swartz. Peprig. Moore and Houlston. \\ Kunze. Fee.}

PLATE IV.-A. VOI. III.
Adiuntım Peppigianum,
" ploridivides,
Prest.
LEPII.

$$
\text { Adiantum-Dry. }
$$

Lucidun-Shining.

A Pretty delieate speeies, requiring skill and attention in order to eultivate it suceessfully.

This Fern was introdueed into England in the year 1844, by Mr. IV. Purdie.

'Ihis species, in eommon with most other Ferns, is liable to be attaeked by insects. Amongst these the Coccus adonidtum, known as the mealy bug, is a terrible pest, as it requires mueh trouble to eradieate. Other speeies are the C.liesperidum, $C$. brometic, (or pine-apple seale,) C. testudo, (turtle seale,) and another genus nearly allied to the Coccus, the Aspidiotus nerii, (or Oleander scale.) 'The Thrips adonidum is mueh to be dreaded, for it pierees the under side of the leaves, and then deposits a globule of a black glutinous flnid in the wound, stopping up the pores; the leaves infeeted speedily lose their green colour, and die. 'The plant louse, (Aphis,) is a troublesome inseet, which more especially attacks the young stems. 
The mitc, (Acarus tellarius,) or red spider, and A. holosericeus are both very destructive, giving the leaves a scorched appearance. Besidcs these, a large green catcrpillar is so rapid in its work of destruction, that if not removed, the fronds are soon all eatcn up; whilst screral small bectles add their ravages to the above pests of our hothouses, grecnhouses, and gardens.

Glabrous; fronds oblong-pinnate, the pinne being altcrnate, and attached by short petioles. Lanceolate, acuminate, coriaceous; the stcrilc serrated fronds being broadest.

Stipes and rachis covered with ferruginous hairs. Rhizoma crceping.

'The colour of the frond a bright olive green, and shining both on the upper and under side; wedge-shaped at the basc.

Length of frond twelve inches.

Sori lincar, continuous, cxtcnding along both margins of the frond to the apex.

A stove Fern.

An inhabitant of Tropical America, the West Indian Islands, and Jamaica.

I am indebted to Mr. Henderson, of Wentworth, for a plant and fronds of this species.

Not common in cultivation; it does not appear to be included in any of the English Nurserymen's Catalogues. It is in that of Messi's. Booth and Son, of ILamburg.

The illustration is from a plant in my own collection. 


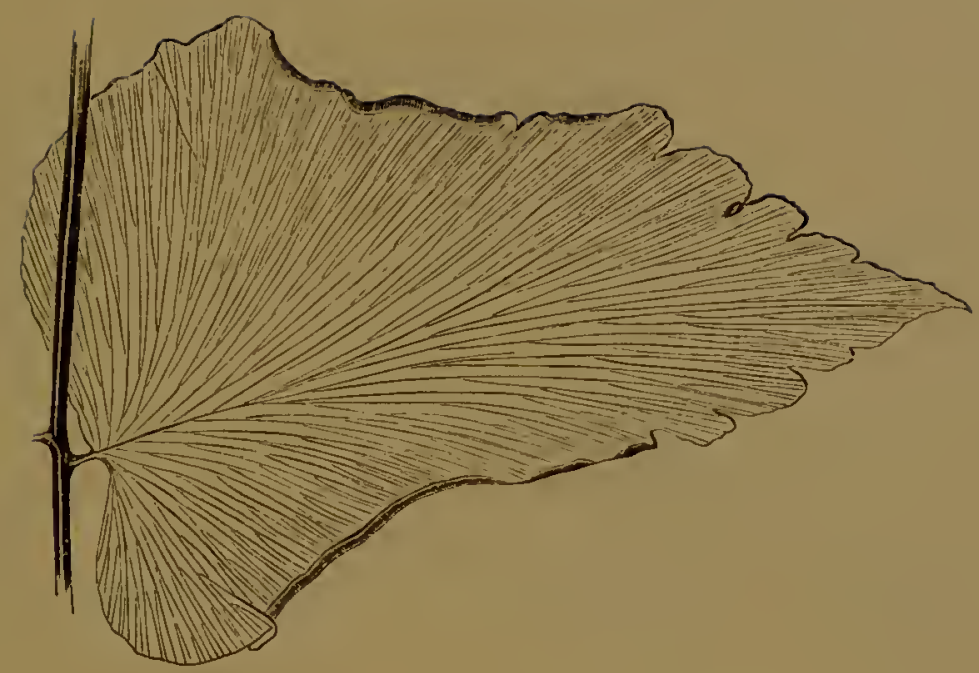

Portion of mature Frond-under side.

\section{ADIANTUM MACROPHYLLUM.}

Swartz. Browne. Sloane. Hooker and Grevillle. Fee. Humboldt and Bonpland. Presl. Willdenow. J. Shith. Kunze. Moore and Houlston.

PLATE IV.-B. VOL. III.

Adiantum microphyllum,

" striatum,
KaULfUSS.

SCHKÜR.

Adiantum-Dry.

Macrophyllum-Long-leaved.

'To the uninitiated, the Adiantum macrophyllum may very readily be mistaken for a Ptoris. The great length of the sori in comparison with the majority of the Adiantums, together with the striking difference in the form of the frond itself, makes this Fern a very distinct species.

The fronds are glabrous, pinnate, and the pinnæ are large, sub-sessile, acutely oblong, lobed and slightlly dentate; sterile 
fronds uncqually welgc-shaped at the basc. 'The edge of the fertilc frouds is contracted, being reflexcd where the sori are situatcd. The colour of the frond bright green.

Its habit is rather ercet, the fronds attached to a creeping rhizoma.

The stipcs and young frond are of a dclicatc palc shining grecn, mingled with patches of a red colour. When mature, the stipes becomes black and cbencous. Rachis slightly fuscopubcscent.

Length of frond from twclve to cightecn inches.

Sori linear and continuous.

This is a very bcautiful evergreen stovc Fern.

A native of the Wcst Indies and Tropical Amcrica, Mexico, and Jamaica.

Although not common in general cultivation, it is in many Nurscrymcn's Catalogucs. It is in thosc of Mcssis. Rollisson, of 'Tooting; E. G. Henderson, of St. John's Wood; A. Henderson, of Pinc-apple Placc; Booth and Son, of Hamburg; Vcitch, of Exeter; Mastcrs, of Cantcrbury; Sim, of Foot's Cray; and Parker, of Holloway.

Plants of this species have bcei. kindly prescnted by Mr. Henderson, of Wentworth; Messrs. A. Henderson, of Pine-applc Place; E. G. Henderson, of St. John's Wood; and Booth and Son, of Hamburg. For fronds I am indebtcd to Mr. Hcnderson, of Wcntworth; Mr. Norman, of Hull; and to Messrs. Booth and Son, of Hamburg.

'The illustration is from a frond sent by Mr. Henderson, of Wcitworth. 



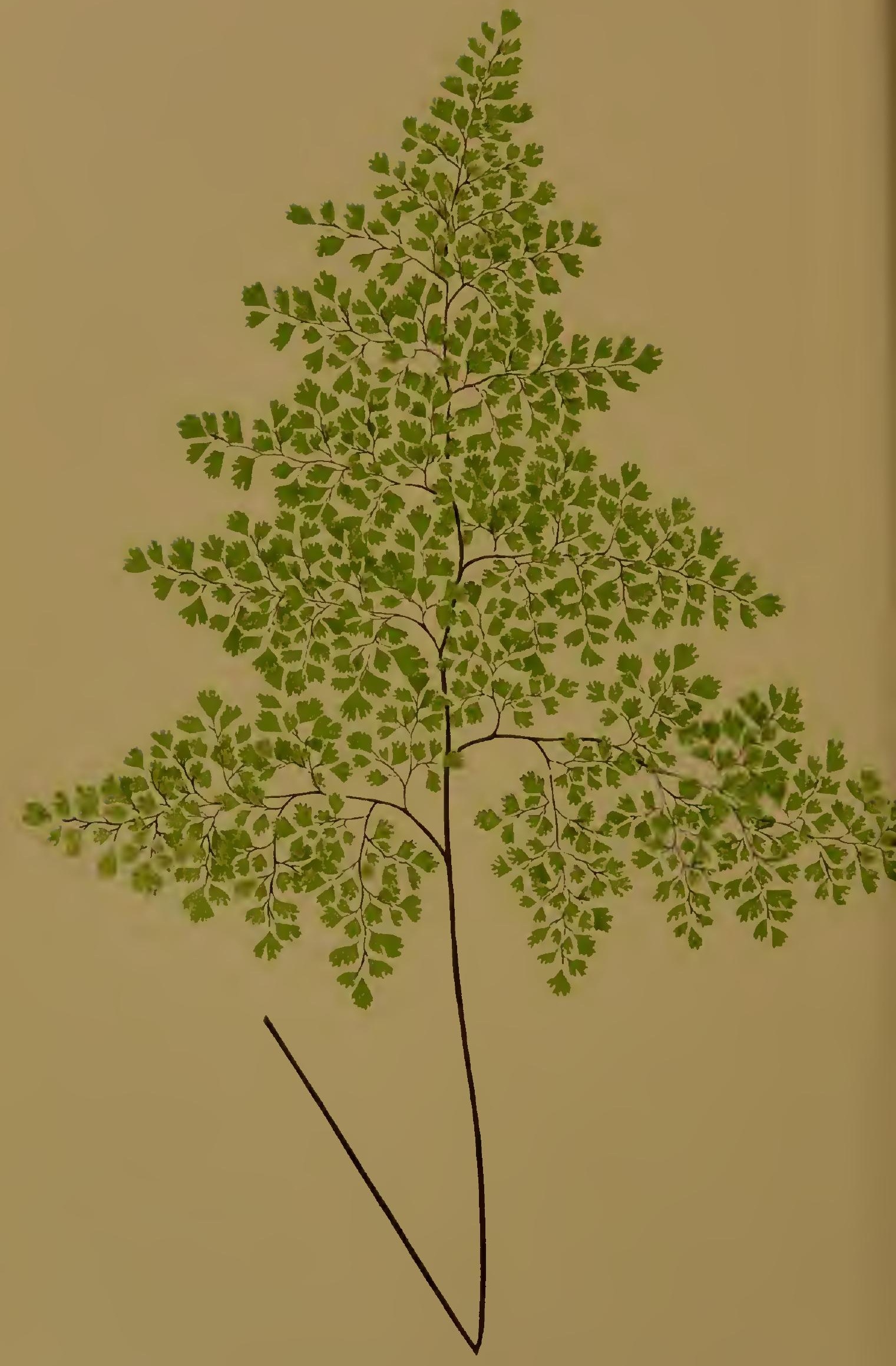




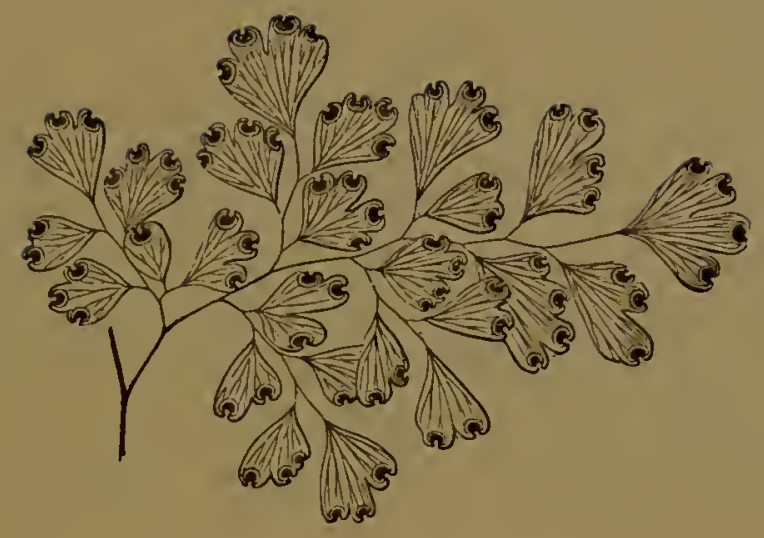

Portion of mature Frond-under side.

\section{ADIANTUM CUNEATUM.}

Kaulfuss. Kunze. J. Smith. Link. Fee. Sprengel. Hoorer and Greville. Moore. Wieldenow. Langsdorff and Fischer. Raddi. Presl.

PLATE V. VOL. III.

Adiantum-Dry.

Cuneatum-Wedge-shaped.

No one can help admiring the graeeful habit and beautiful form of the Brazilian Maiden-hair, (Adiantum cuneatum.) It is readily cultivated, requiring less attention than almost any other Fern. Give the plant plenty of pot room, good drainagc, and a rich light soil, and do not let the fronds become too wet, and no further care is needed in order to procure a compact, handsome plant, as near perfection in the elegance of its form as it is possible to attain; indeed in this respeet it is second to nonc. It is a species with fronds so fragile and delieate that it will not bear the drip of water, often seen in badlyglazed grcenhouses during rainy weather.

VOL. III. 
A. cuneatum is perhaps more generally cultivated in England than any other Fern. It is so rcadily propagated from spores, that wherever it is grown a stock of young plants are soon obtained, even when no eare is taken to rear them from sporules, for they spring up in the pots which stand around them.

This Fern was received at the Royal Botanic Gardens, Kew, in the year 1841, from the Royal Botanic Gardens of Berlin.

Frond glabrous, triquadripinnate, very slender, membranaceous pinnules upon long slender ebeneous petiolules; pinnules wedgeshaped, the superior margin rounded, obtuse lobes, pinnules numerous, sterile lobes serrulate; fertile lobes emarginate. Stipes and raehis shining, cbeneous, and having a plum-coloured bloom upon them.

The fronds, which are more or less erect, are attached to a somewhat tufted rhizoma. They are usually about twelve inches in length. One of my plants has fronds eighteen inches long.

Sori of a moderate size, from four to six on a pinnule; indusium reniform.

A. cuneatum is an evergreen stove species.

An inhabitant of Brazil, having been found at St. Catharine's, on the Organ Mountains, near Rio, and at Uraguay.

My thanks are due to Mr. Ingram, of Bclvoir Castle; Mr. Ingram, of the Royal Gardens of Windsor; Messrs. Rollisson, of Tooting; Messrs. Booth, of Hamburg; and to Mr. Stewart, of Sudbury Castlc, for plants of this speeies; and to Mr. Henderson, of Wentworth, for fructified fronds.

The young fronds, when they first eome up are pink, when they first expand are of a pale green, and afterwards beeome a rich green colour. The frond is naked for two thirds of its length, and is somewhat wedge-shaped.

It is in the Fern Catalogues of Messrs. E. G. Henderson, of St. John's Wood; A. Hcnderson, of Pine-apple Place; R. Sim, of Foot's Cray; Veitch, of Excter; Parker, of Holloway; Rollisson, of Tooting; Booth and Son, of Hamburg; and E. Cooling, of Dcrby.

'The illustration is from a plant in my own collection. 


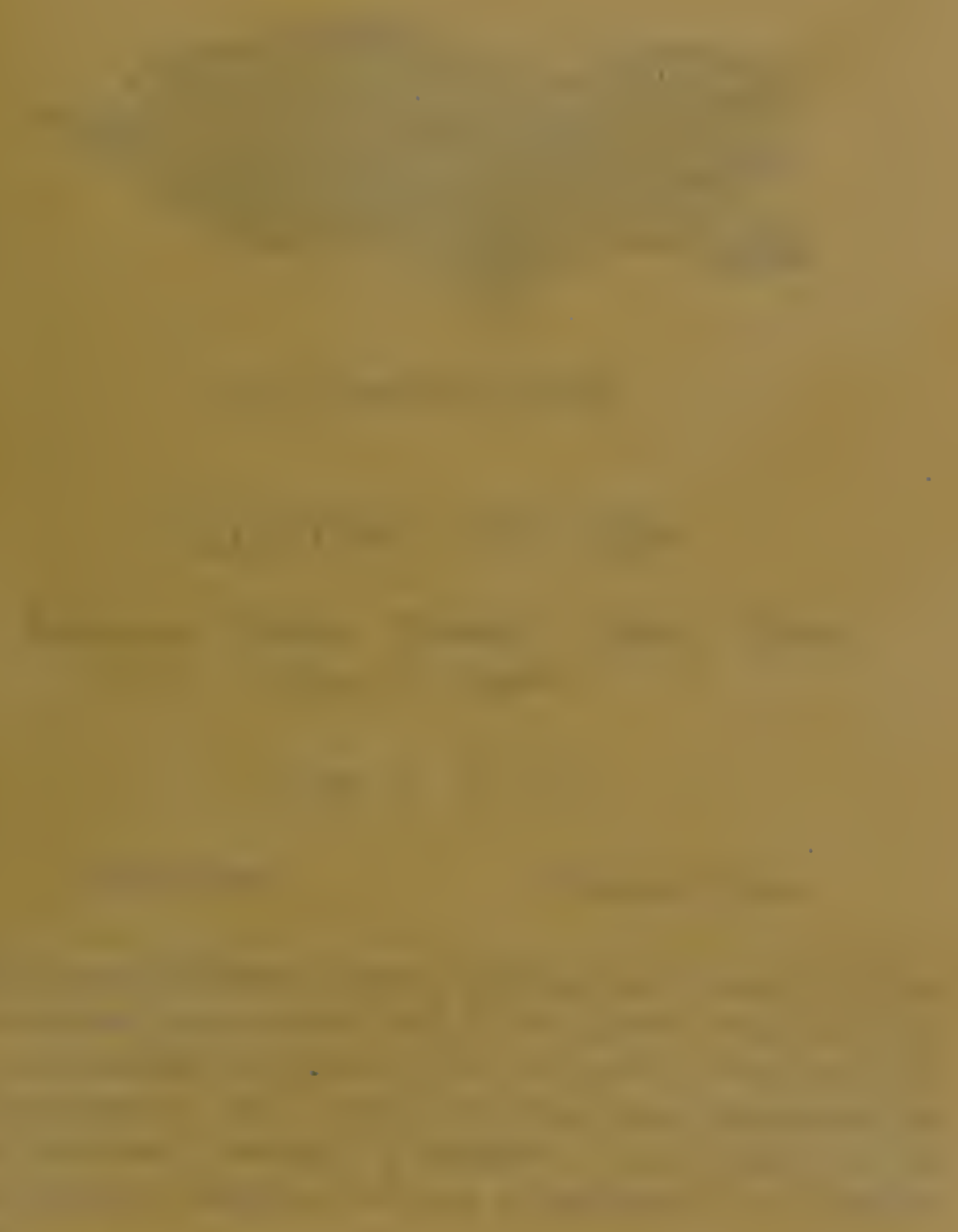
$1+$

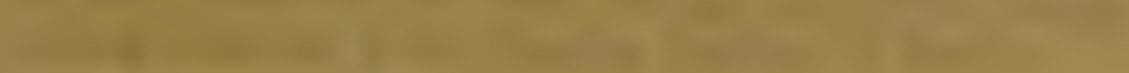

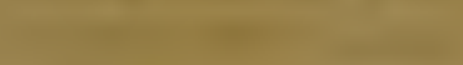

The

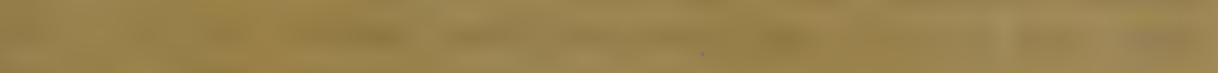

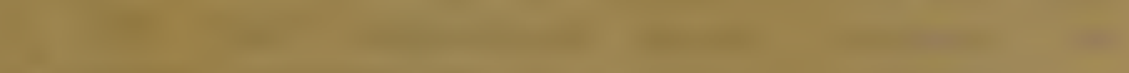

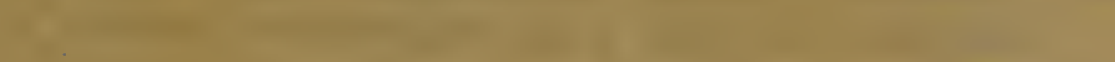
- 



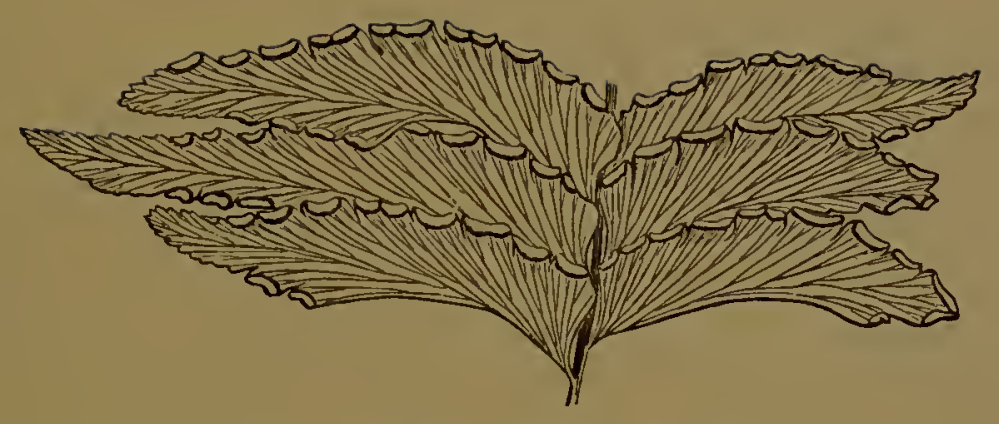

Portion of mature Frond-under side.

\section{ADIANTUM CURVATUM.}

Kaulfuss. Kunze. Hooker. MoORe. Link. FeE. J. Smith.

PI.ATE VI. VOL. III.

Adiantum-Dry. Curvatum-Curred.

The genus Adiantum contains, perhaps, more beautiful Ferns than is found in any other; and of this lovely tribe, but few arc more beautiful or graceful than the curved fronds of Adiantum curvatum. It is a species seldom met with except in good collections, although it appears to be in most of the Nurserymen's Catalogues, and may be purchased at a reasonable price.

It was first introduced to $\mathrm{Kew}$, in the year 1841, having bcen rcceived from the Royal Botanic Gardens of Berlin.

An evergrecn stove species.

Fronds glabrous, pedate, acuminate; the pinnules oblongobtusc, pinnæ curved, imbricate, superior margin and apex serrated. The frond dichotomously divided, tripinnate, the pinnulcs attached to the midrib by a very short foot-stalk.

The fronds arc lateral, and rise out of a short creeping rhizoma. 
Length of the frond from eighteen inches to two feet, rachis slightly pubescent, black in colour, except when young-then green; colour of the frond rich green.

Sori oblong, reniform, and solitary, about seven on a pinnule.

Sir William Hooker states in his "Species Filicum," that Adiantum angustatum of Kaulfuss is probably a form of this Fern, and also that $A$. humile of Kunze, and $A$. tetragonum of Schrader and Martins, may eventually prove to be varieties of $A$. curvatum. He also remarks that "if any of the pinnules bear sori on the lower as well as the upper margin, (which I have never known to be the case,) it (Adiantum curvatum,) would appear almost identical with $A$. tetragonum of Schrader and Martins." One of my plants has borne sori on the lower margin, near the apex of the pinnule, yet sparingly. I forwarded a frond having sori on the lower margin to Sir William Hooker, and his son (Dr. Hooker,) informs me that there are no fronds exhibiting this character in the extensive herbarium at Kew.

A Brazilian Fern, found in dry woods at Sierra de Santa Bricla.

This Fern requires shade, a stove temperature, and not too much water.

My thanks are due to Mr. Henderson, of Wentworth; and to Mr. Masters, of the Exotic Nursery, Canterbury, for plants; and to Mr. Henderson, of Wentworth, for fructified fronds.

It is in the Catalogues of Messrs. E. G. Henderson, of Sit. John's Wood; A. Henderson, of Pine-apple Place; Veitch, of Exeter; Rollisson, of Tooting; Parker, of Holloway; Sim, of Foot's Cray; and Booth, of Hamburg.

The illustration is from a frond sent by Mr. Henderson, of Wentworth. 
$x^{2}=1$

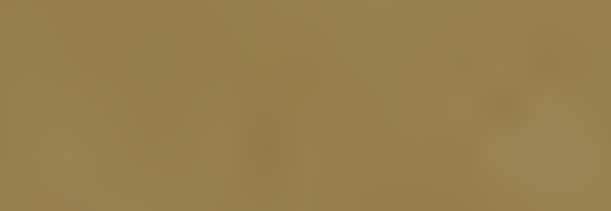
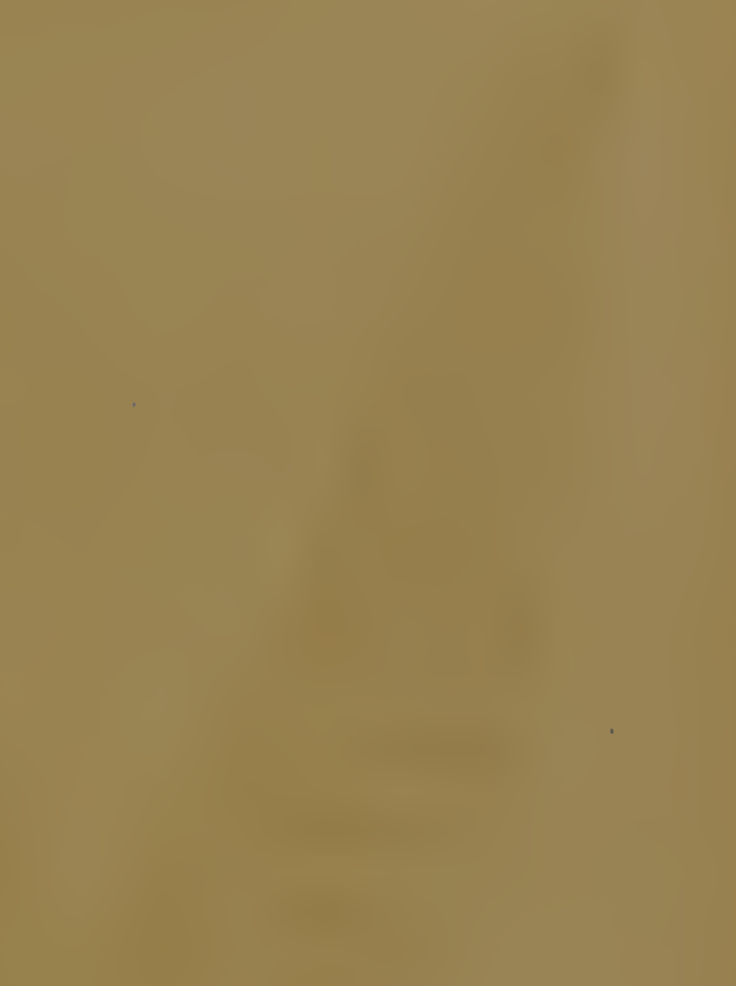


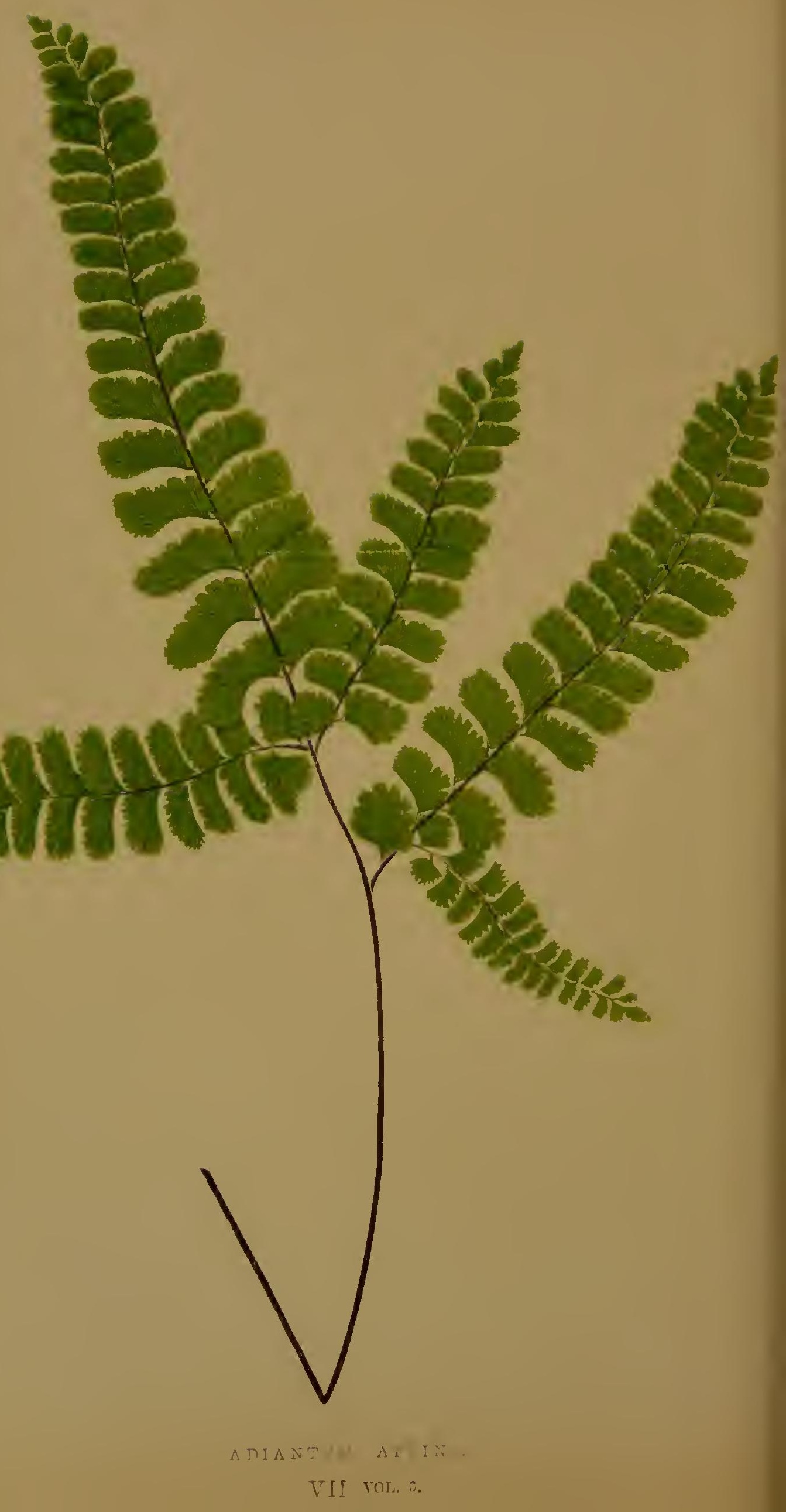



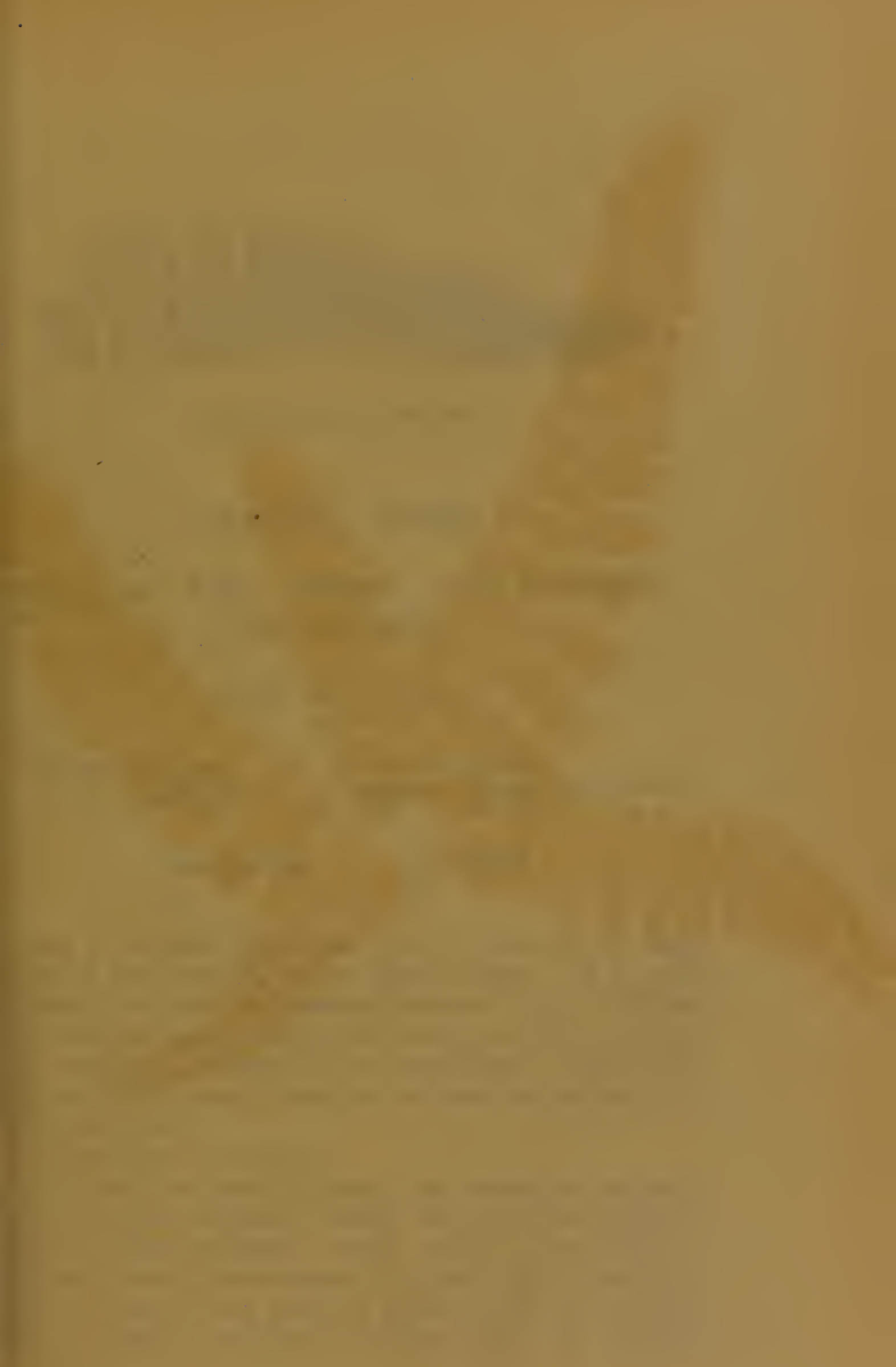

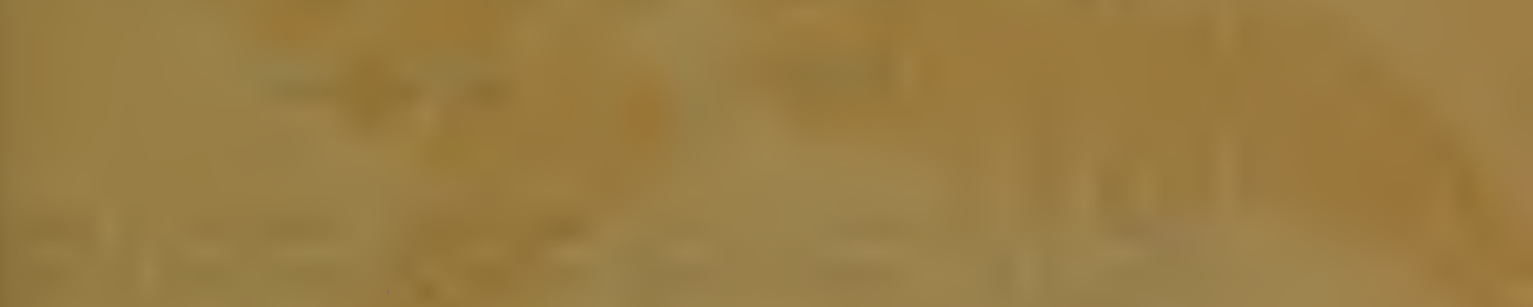

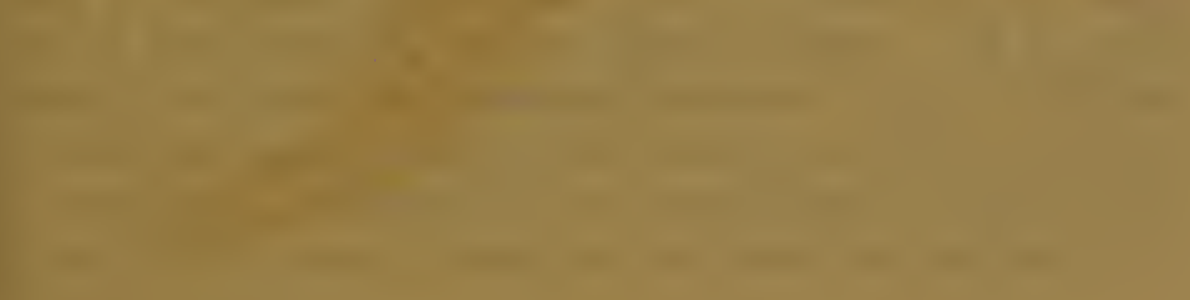

se

$= \pm$

$-=--i=-i=$

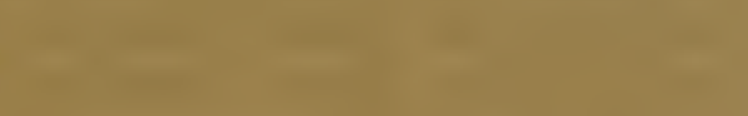

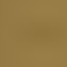

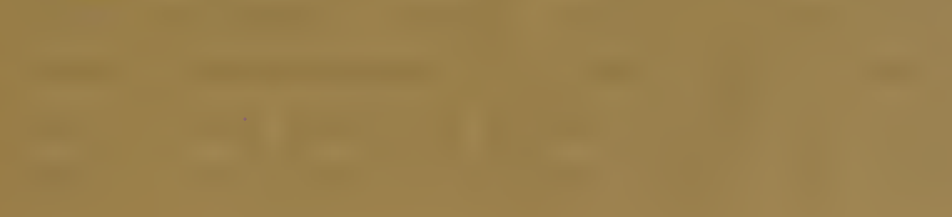




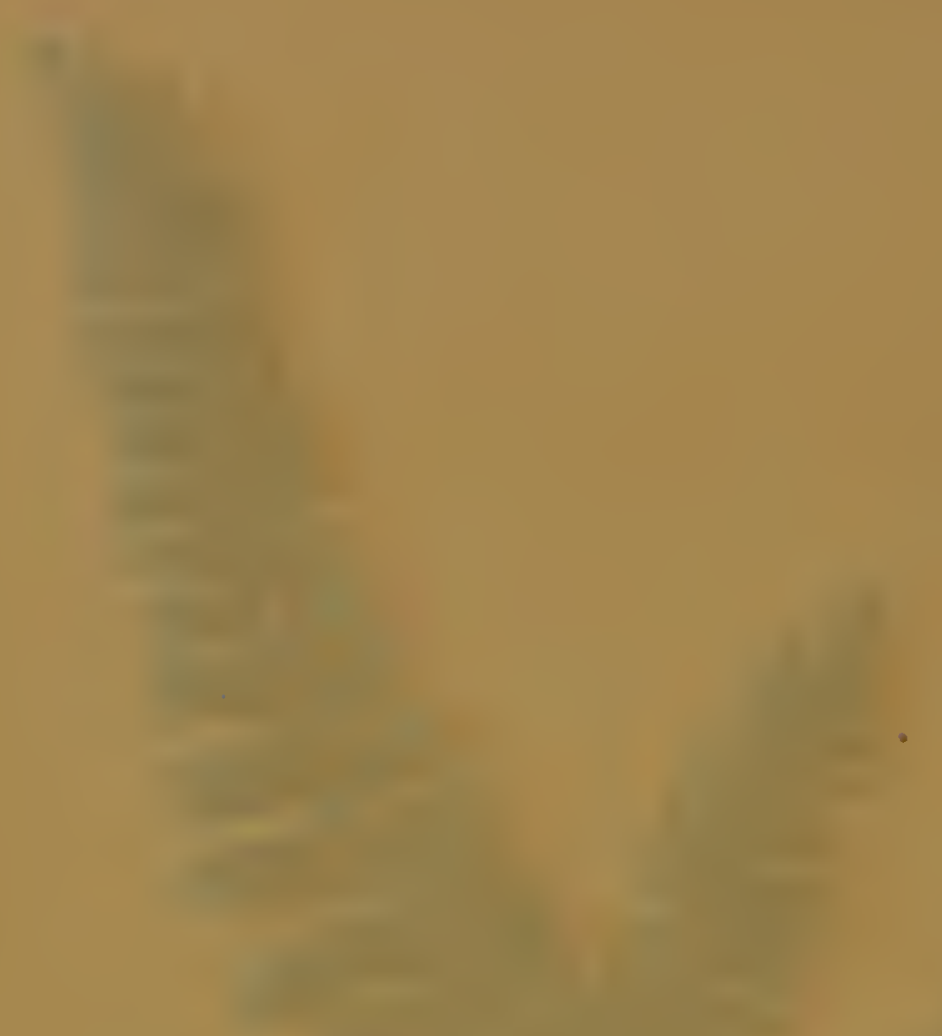

।

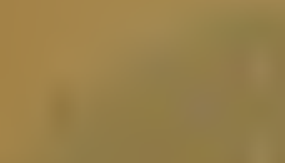
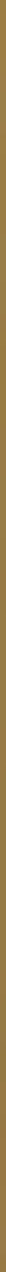


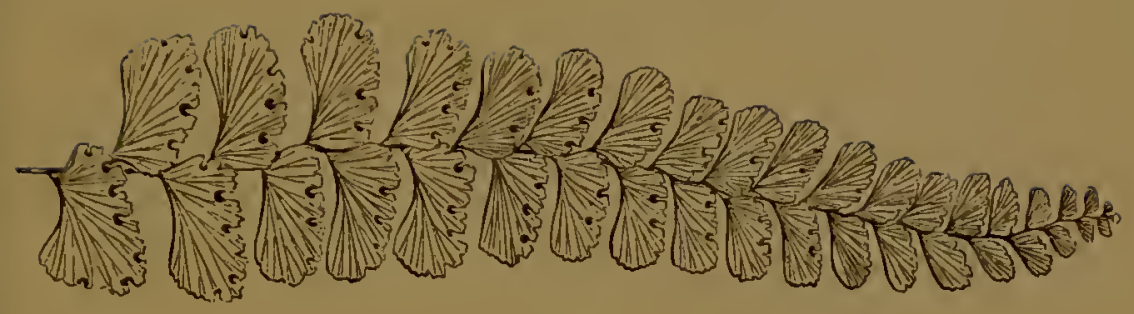

Portion of mature Frond-under side.

\section{ADIANTUM AFFINE.}

\section{Willdenow. Presl. Hooker. Allan Cunningham.} Fee. Endlicher.

PLATE VII. VOL. III.
Adiantum setulosum,
J. Smith. Kunze.
" trapeziforne,
SchkuHr. Forster, not Linnæus.

Adiantum-Dry. Affine-Allied.

This lovely little Maiden-hair Fern is found in the damp woods of New Zealand, and on Norfolk Island. It is easily eultivated, and makes an interesting specimen. Dr. M'e William introduced this species into England in the year 1845. Although not yet generally cultivated, it is, nevertheless in many of our principal Nurserymen's Catalogues, and may be purchased at a reasonable price.

An evergrcen stove species.

The fronds are usually bipinnate, yet occasionally tripinnate, having lanccolate-acuminate pinne, the lower ones being bipartite; pinnules dimidiate, oblong, obtusely wedge-shaped at the base, eurved, membranaccous, superior margin of the pinnæ bluntly crenate, having the deep sinuses soriferous. Sori from four to eight on a pinnulc, indusium hairy and reniform. VOL III. 
The pinnules have a few almost microscopical black bristlelikc hairs on their upper surface: occasionally fronds arc found with the liairs numerous and large, both on the upper and under surfacc.

Colour of the frond a vivid green.

Stipes and rachis slender and glabrous, shining and cbencous; latcral, attached to a creeping rhizoma, which is slendcr.

Length of frond occasionally twelve inches, morc than half of the rachis bcing naked.

For plants of this specics, I am indebted to Mr. Ingram, of Belvoir Castle; Mr. E. G. Henderson, of St. John's Wood; and Mr. Masters of the Exotic Nurscry, Cantcrbury; and for fronds to Mr. Henderson, of Wentworth.

It is in the Fern Catalogues of Messrs. A. Henderson, of Pine-apple Place; E. G. Hcuderson, of the Wellington Nurscry; Rollisson, of 'Tooting; Sim, of Foot's Cray; Veitch, Jun., of Chelsea; Parker, of Holloway; and E. Cooling, of Derby.

The illustration is from a plant in my own collection. 


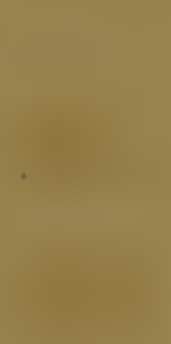

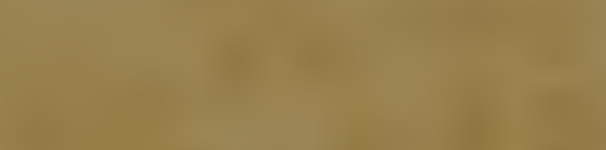

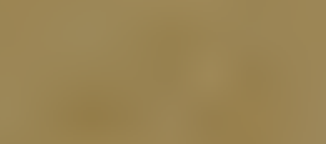

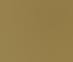

?

18

$-\frac{2}{2}=\frac{1}{2}$

$1+5$

ans

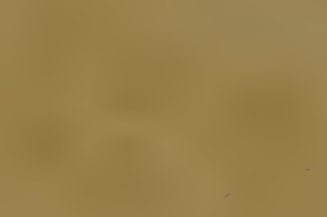

$-3$

$-5=0$

$x^{2}$

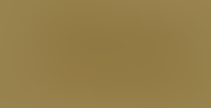

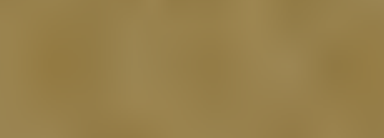
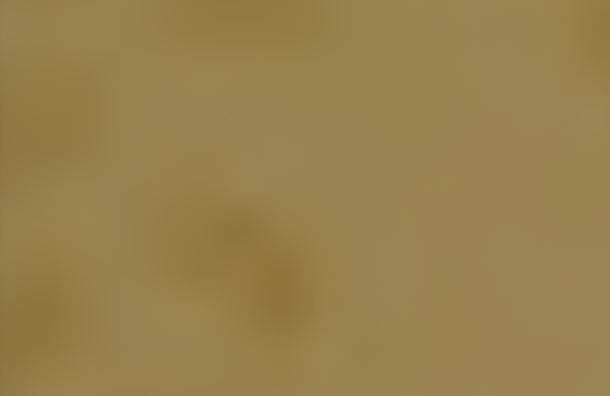

?

tis 9.92
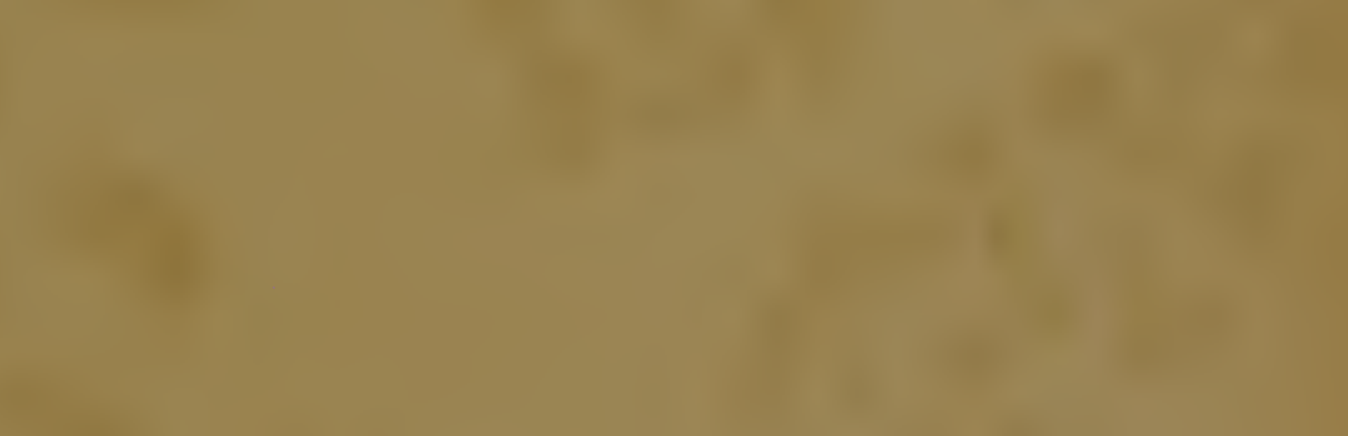

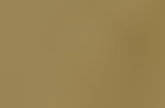

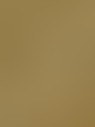

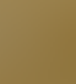
1

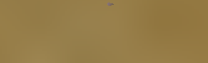

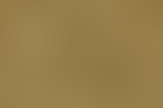
$1+2=$

$\sqrt{1+2}$ 


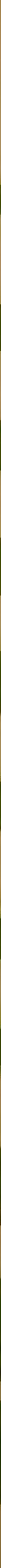


(7)

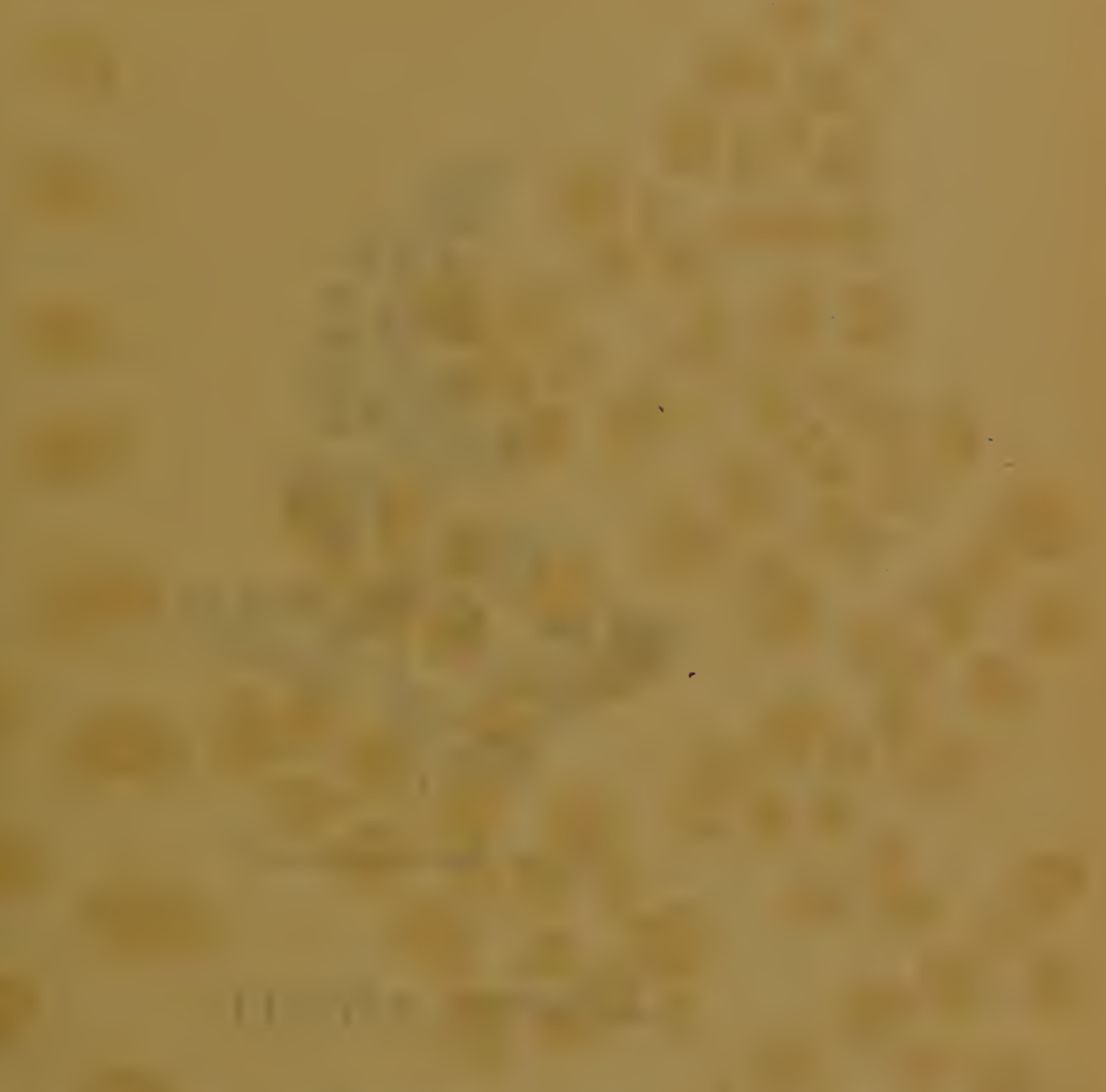

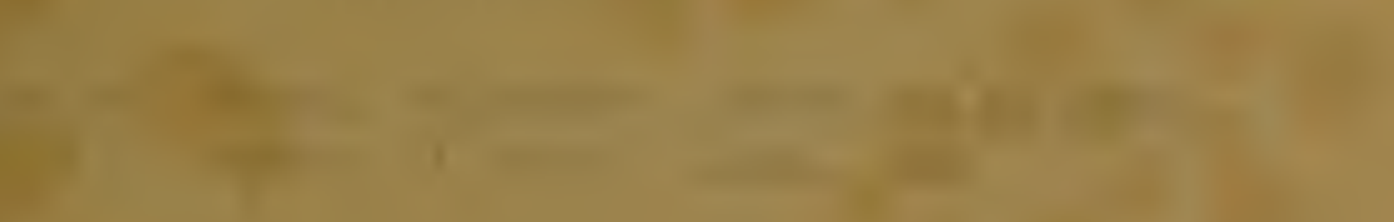

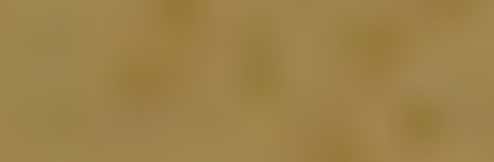

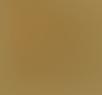

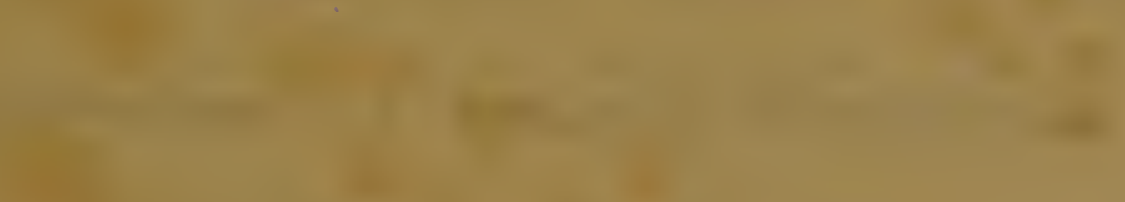

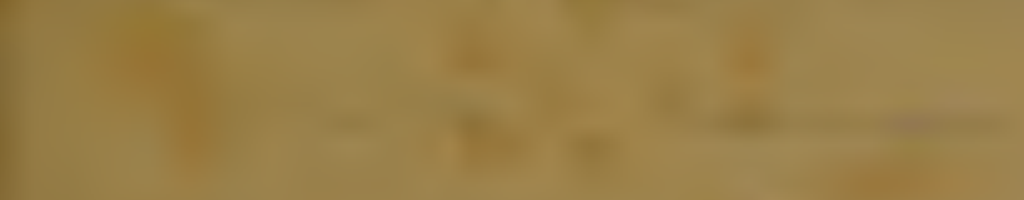

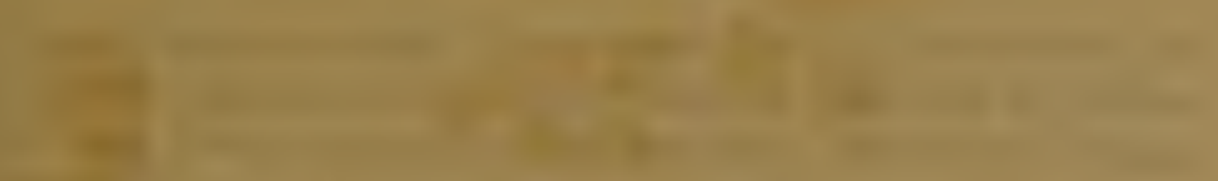

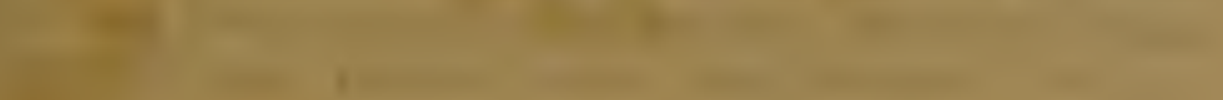

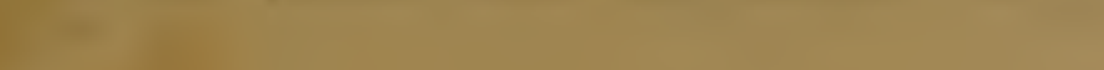


t.<smiles>C1C2C3C[C@H]2[C@@H]13</smiles>

efs

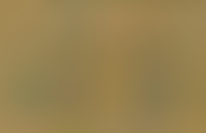

and an

$x^{4}{ }^{4}$

年

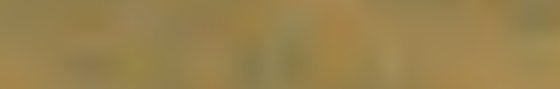

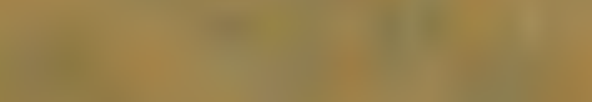

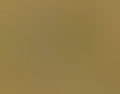

$$
\text { tal }
$$

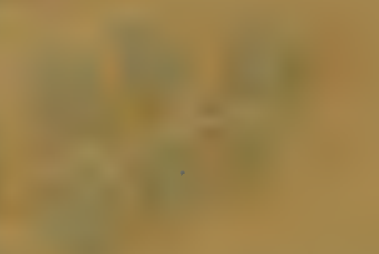

13
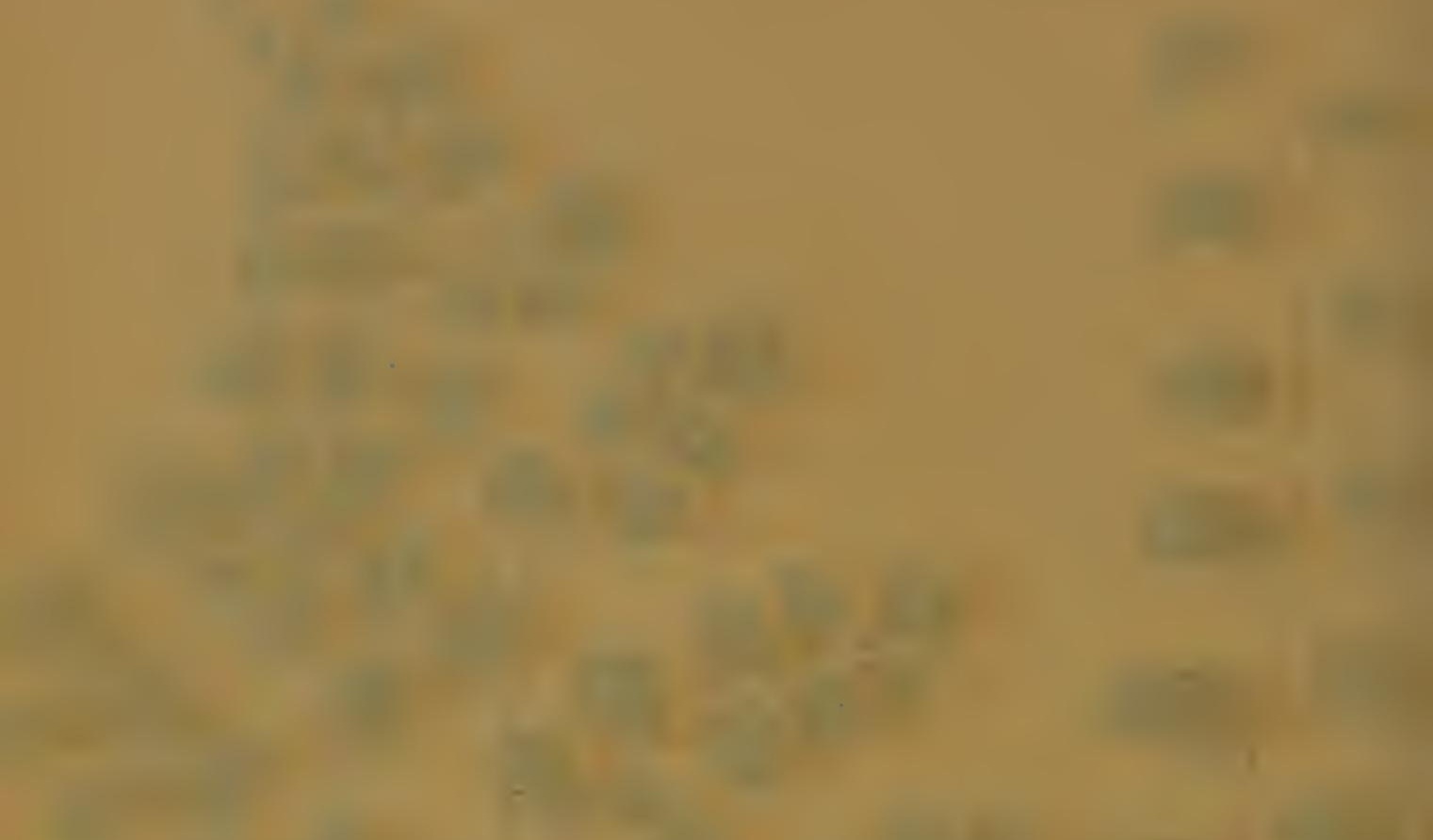

$-$

$\left.x_{4}+7\right)$

$\frac{17}{10}$$$
\text { . }
$$
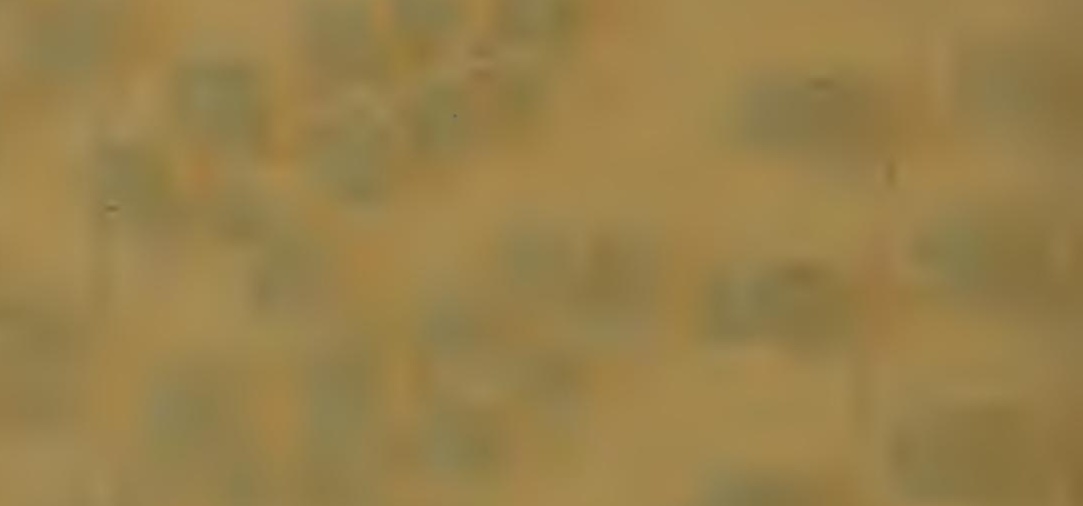

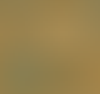

$\frac{x}{3}+2$

a.

$$
\begin{aligned}
& \text { a. } 8=7 \\
& \text { ting }
\end{aligned}
$$

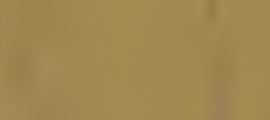

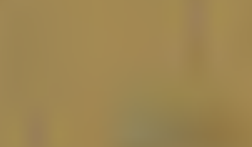
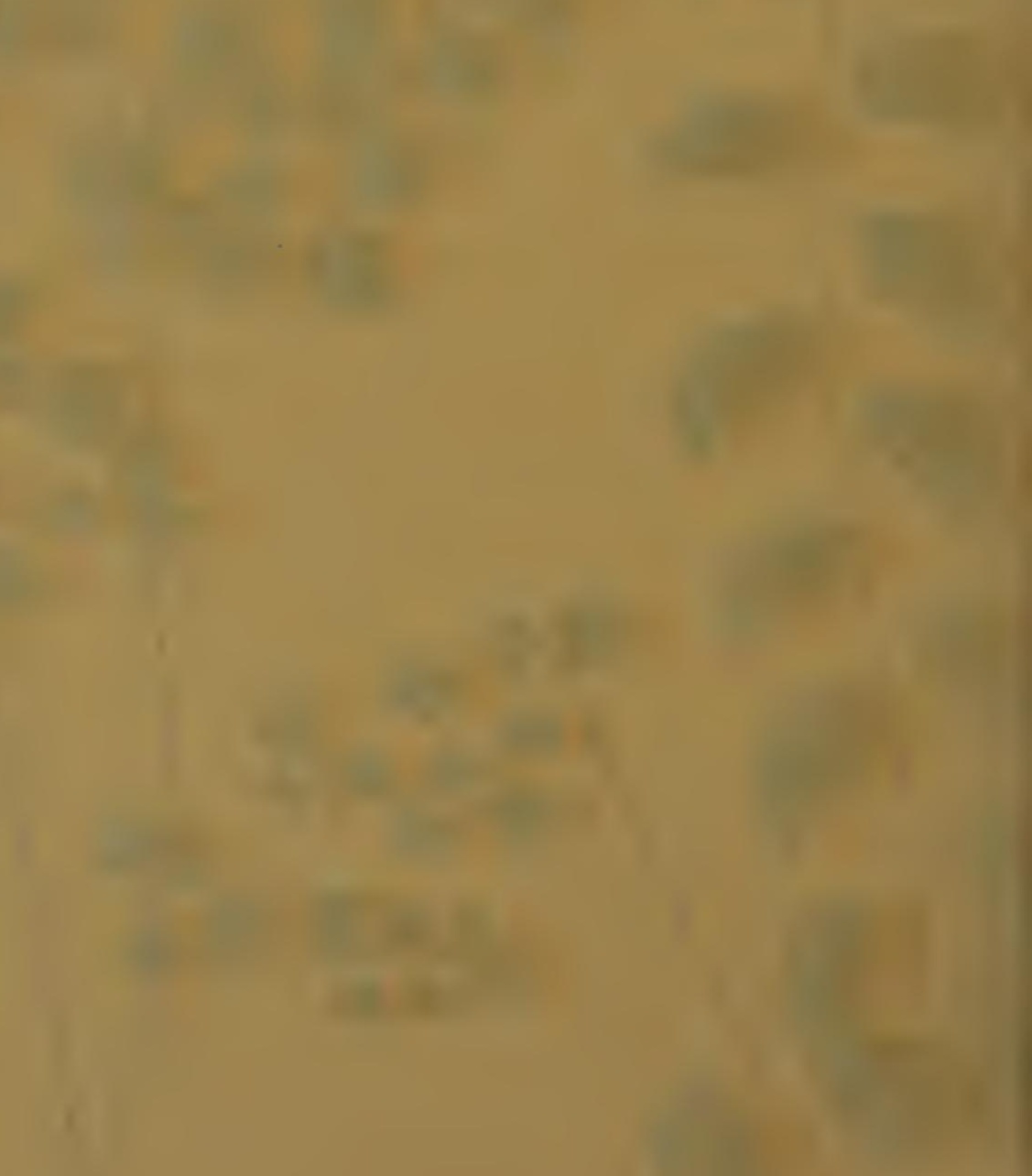


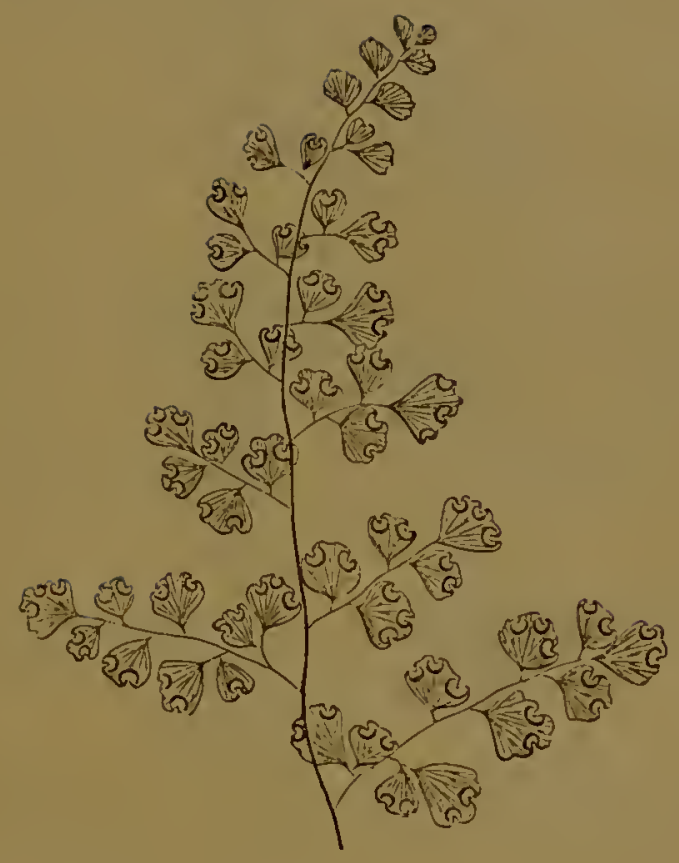

Portion of mature Frond-under side.

\section{ADIANTUM ASSIMILE.}

Swartz. Brown. Willdenow. Moore and Houlston. Hoокек. J. Sмiтh. Kunze. FeE.

PIATE VIII.-A. VOL. III.

Adiuntum trigonum, Thabulardiere. Willdegort. Prest.

Adiantum-Dry. Assimile-Assimilated.

Ine Adianlum assimile is a common Fcrn in Australasia, and one which appears to vary considerably in different situations. 'The usual form cultivated in this country is that which is found in its wild state, growing in low damp situations. A more VOL. III. 
robust form grows in localitics that are dricr; both forms may be scen at the Kew Gardens. Sir William Hooker appears to consider that $A$. assimile and $A$. cethiopicum may be the same plant.

It was introduced into the Royal Gardens, Kew, by A. Cunningham, lisq., in the year 1823.

This speeies is a greenhouse Fern, yet almost, if not quite, hardy in some sheltered situations. I have had a plant which has lived out of cloors for the last five years, but has not, however, flourished. It is a deciduous Fern, and one not nneommonly met with in greenhouses, and often erroneously named $\dot{A}$. cuneatum. The young fronds are very delicate, and are palc green in eolonr.

A native of Tan Diemen's Lind, New South Wales, New Holland, New Zealand, Port Jackson, Encounter Bay, Swan River, ete.

'This delieate and bcautiful species has glabrons fronds, whieh are slender; tripinnate; small pinnules, whieh are rhomboidal, wedge-shaped at the base, and slightly erenate at the margin.

Sori small and reniform.

Fronds usually a foot long, of a vivid green eolour. Rachis and stipes smooth; fronds lateral, attached to a slender ereeping rhizoma.

It is in the Catalogues of Messrs. A. Henderson, of Pine-apple Place; E. G. Henderson, of St. John's Wood; Tcitch, of Chelsca; Sim, of Foot's Cray; Parker, of Ilolloway; Masters, of Canterbury; and Booth, of I Iamburg.

I am indebted to Messirs. Booth, of Hamburg, for a plant; and to Mr. Norman, of Hull, and Mr. Menderson, of Wentworth, for fronds.

A species rery readily propagated lyy divisions of the root. 'The illustration is from a plant in my own eollection. 


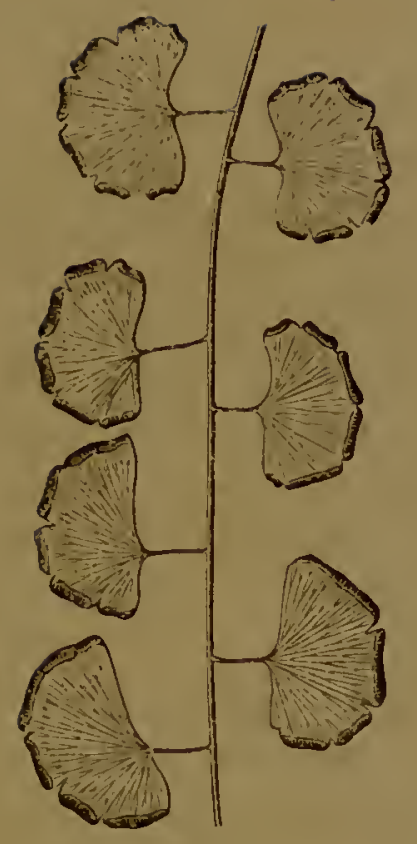

Portion of mature Frond--muder side.

\section{ADIANTUM LUNULATUM.}

Burmana. Willdenow. Sprengel. Swartz. Presl. Hooker and Grevilde. Wallich. Fee. Moore and Houlston. Retzius. Rheed, not Houttuyn.

$$
\text { HI.ATE VIIL-H. VOL. IIL. }
$$

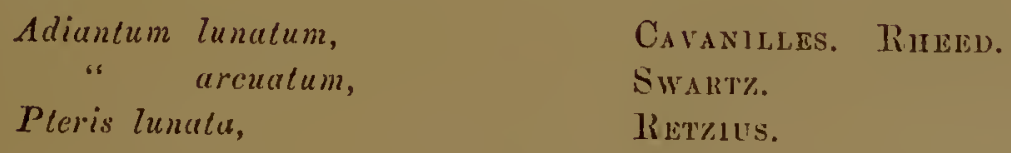

$$
\text { Adiuntum-Dry. Tunulatum-Crescent-leaved. }
$$

A RARE but beautiful species, with a slender habit, the piunules large and of the form of a half-moon. The Adiantum arcuatum of Swartz is considered to be a varicty of this Fern, and 
Sir William Hooker thinks that the Brazilian Fern, (Adiuntum defectens, of Martens,) may also prove to be anotlier form of A. lunulatum.

A stove Fern, which is deciduous.

A. lunulatum is a native of the East Indies, Malay Islinds, Africa, the Islands of Ceylon and Java, Mexico, the Cape de Verde Islands, the Organ Mountains in Brazil, Acapulco, Quorra near Attah, Panama, Minas-Gerra, ete.

The form of the frond is oblong, pinnate, pimine alternate, lumate on lengthened petioles or foot-stalks, lobed on the superior margin, blunt at the base. Fronds glabrous; the sterile ones pendulous, and the fertile ones erect. Stipes and rachis, glabrous, ebeneous; the rachis often extending beyond the pinne, rooting at the apex.

Length of frond about a foot; colour brilliant green. 'Terminal, attached to a fasciculate rhizoma.

Sori linear, approximate, frequently bccoming confluent.

I have been unable to procure a plant. 'To Sir William Hooker my thanks are due for fronds.

It appears only to be included in the Fern Catalogue of Messis. Rollisson, of Tooting.

Propagated by allowing the apex of the fronds to root into the soil.

The illustration is from a frond given to me by Sir William llooker. 



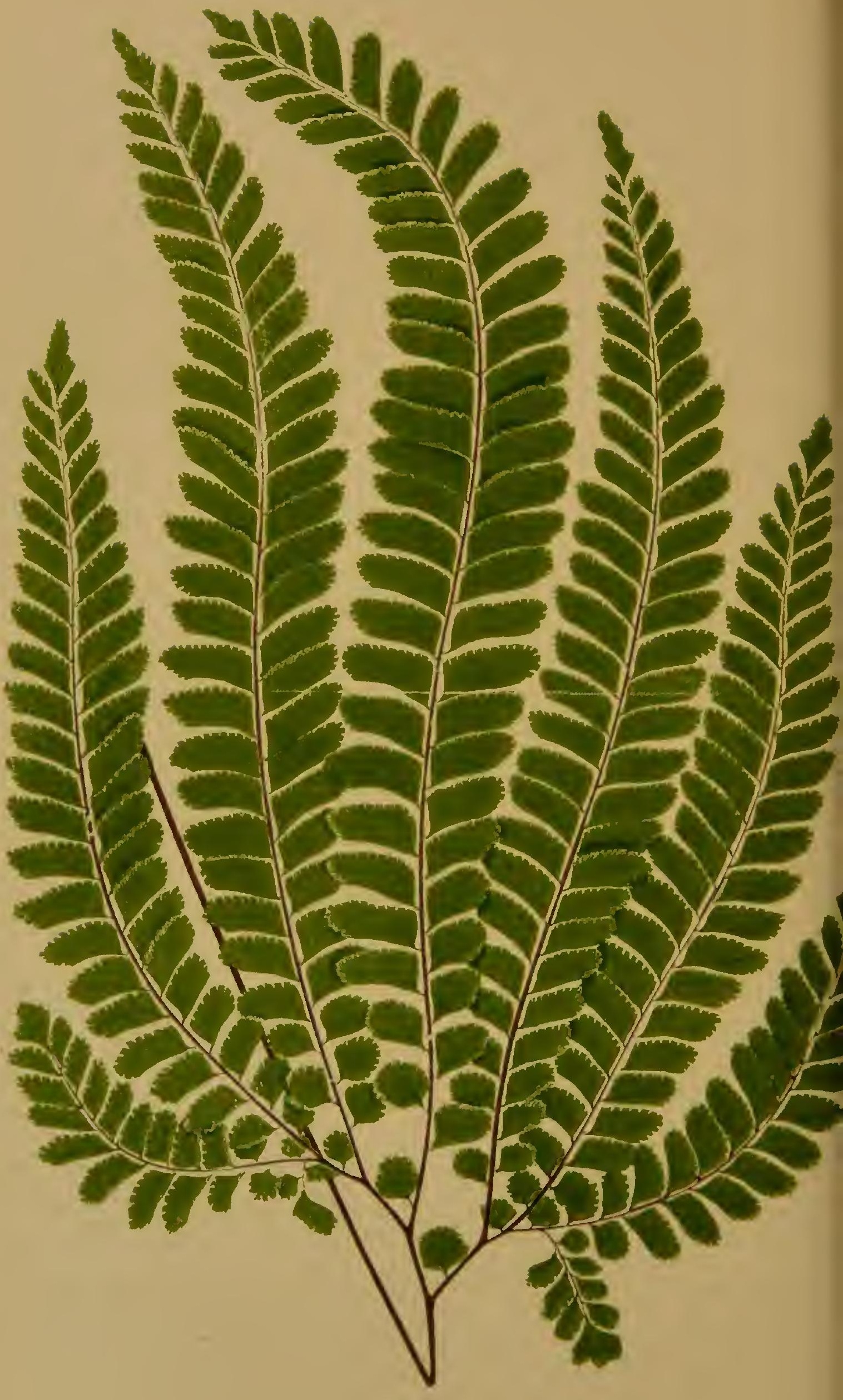




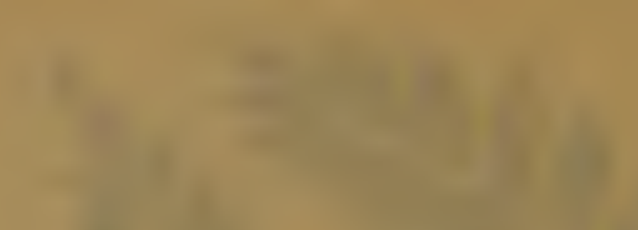

it -310

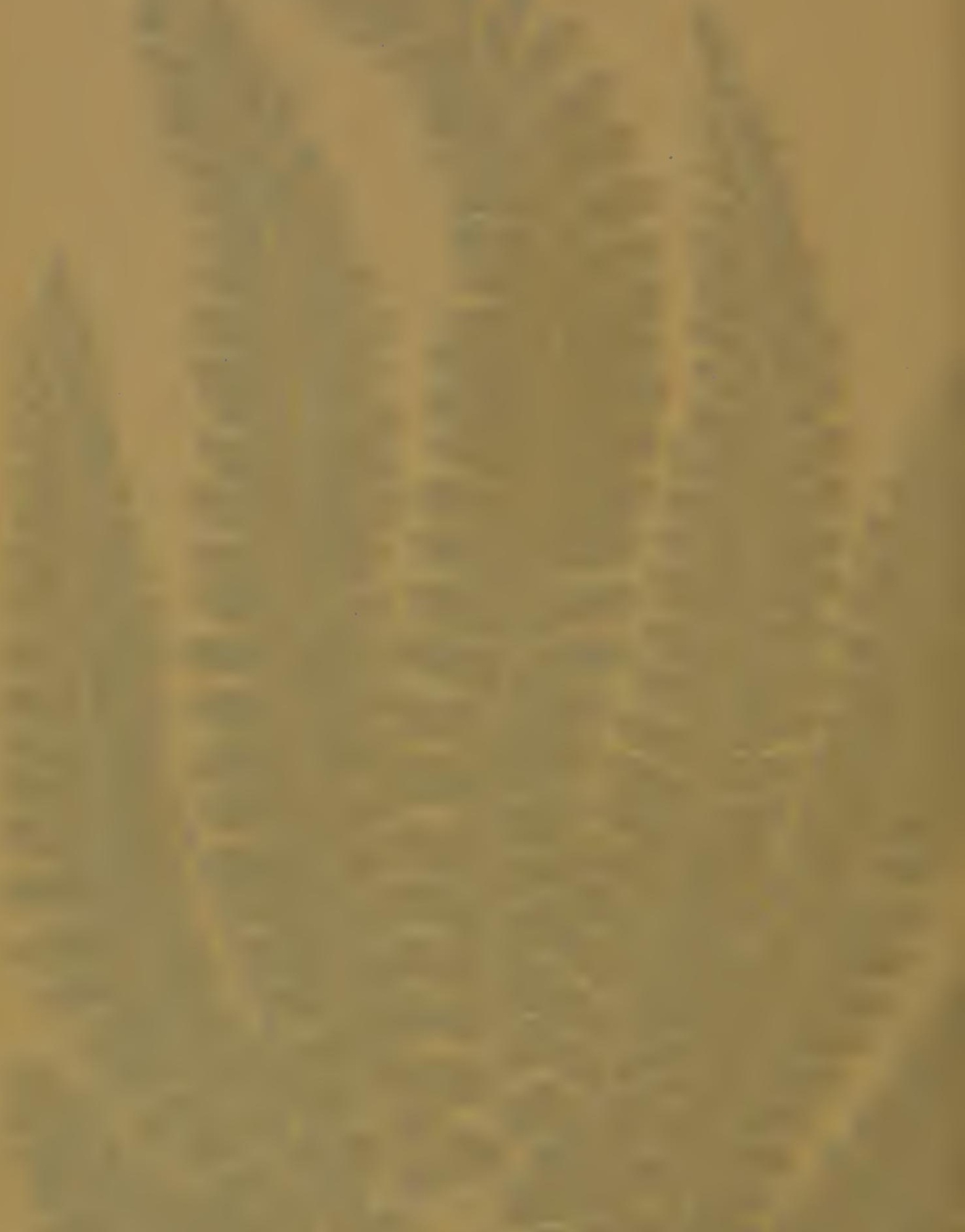

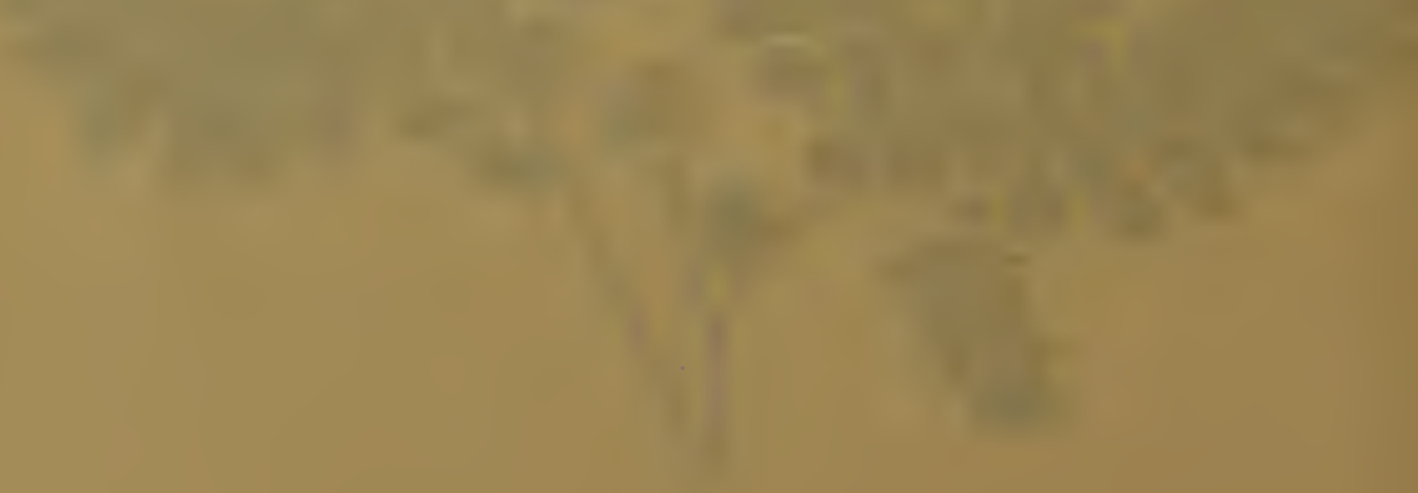

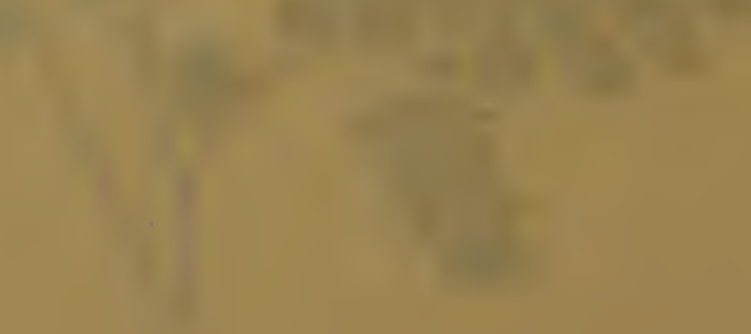




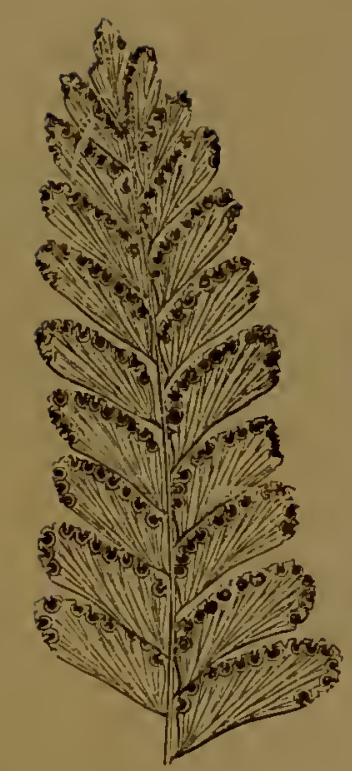

Portion of mature Frond-uncer side.

\section{ADIANTUM PUBESCENS.}

Schruhr. Moore and Houlston. J. Shitil. Kunze.

Willdenow. Link, not Raddi.

PLATE IX. YOL. 111.

$\begin{array}{cc}\text { Adiantum } & \text { hispidulum, } \\ \text { " } & \text { " } \\ \text { " } & \text { pedutum, } \\ \text { " } & \text { plicatum, }\end{array}$

Adiantum-Dry.
SWARTZ. FEE.

Hooker and Greville.

Fonster.

KaULFuss.

Pubescens-Downy.

'Tiris Fern has been very correctly named pubescens, indeed it is as pubescent as it is possible for a Fern to be; the stem being quite rough with the vast number of short brown hairs. It is a handsome Fern, easily cultivated, requiring but little 
attention, and produeing a noble-looking speeimen when properly grown.

It was raised at the Royal Gardens, Kew, in the ycar 1834, and is now very generally eultivated in Great Britain.

An evergreen greenhouse spccies, very oinamental.

A native of New Zealand and New Holland.

Fronds pubeseent, pedate, branches linear, narrow, acuminate, pinnate; with numerous pinnules, which are dimidiate, bluntly oblong, wedge-shaped at the base, margin erenate.

Length of frond from one foot to eightecn inches. Colour decp green.

Sori small, numerous, from twelve to sixteen on a pinnule; indusium reniform and hairy.

Fronds terminal, nearly all fertile, rising out of a somewhat tufted rhizoma.

My thanks are due to Mr. Ingram, of the Royal Gardens, Windsor, and Mr. Henderson, of Wentworth, for plants of this speeics; and to the latter gentleman, Mrs. Riley, of Papplewick, and Mr. Norman, of Hull, for fronds.

This speeies is in the Fern Catalogues of Messrs. E. G. Henderson, of St. John's Wood; Rollisson, of Tooting; A. Henderson, of Pine-apple Place; Veiteh, of Exeter; Sim, of Foot's Cray; Masters, of Canterbury; Parker, of Holloway; Booth and Son, of Hamburg; and E. Cooling, of Derby.

The illustration is from a plant in my own eollcetion. 



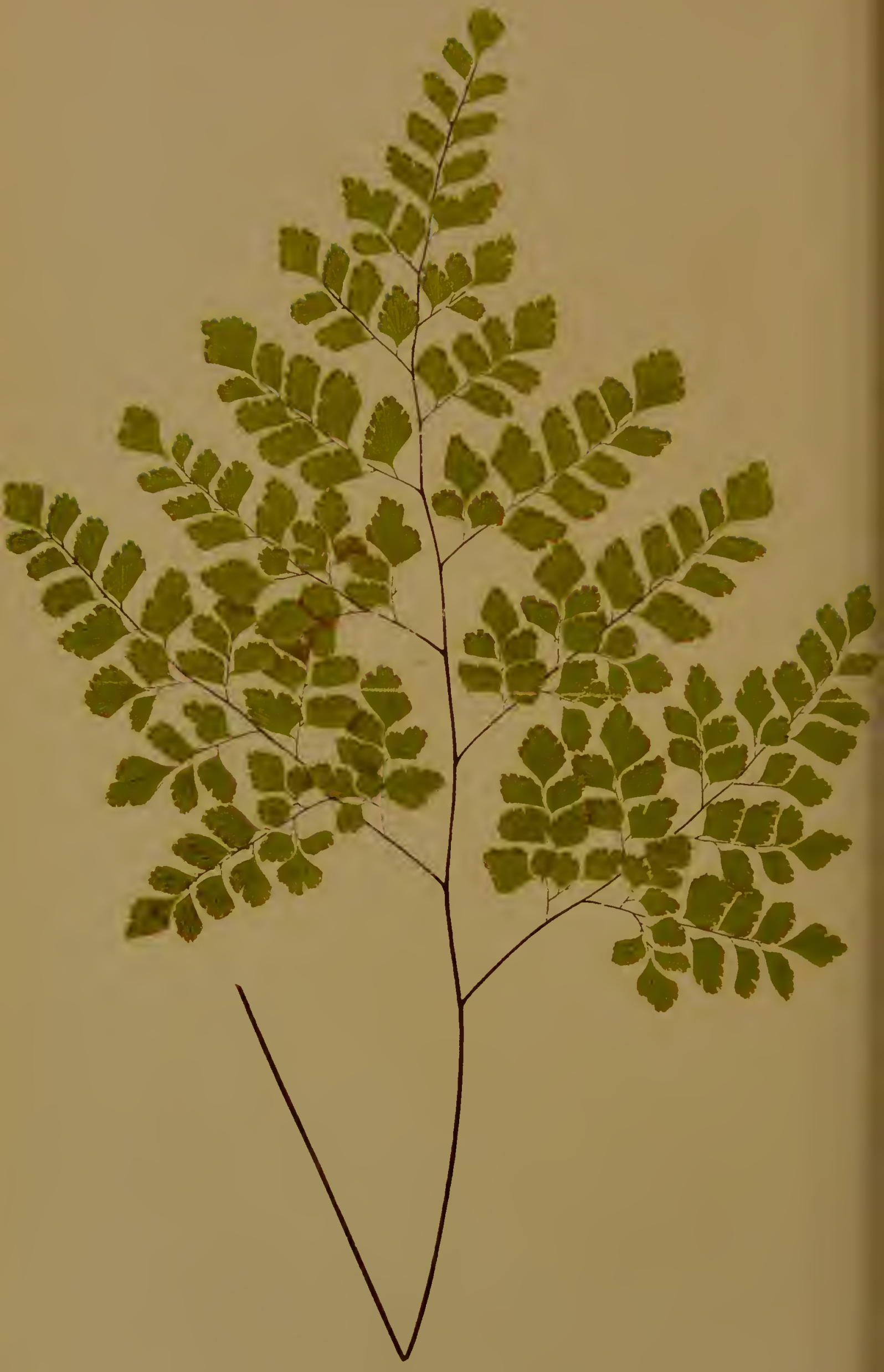




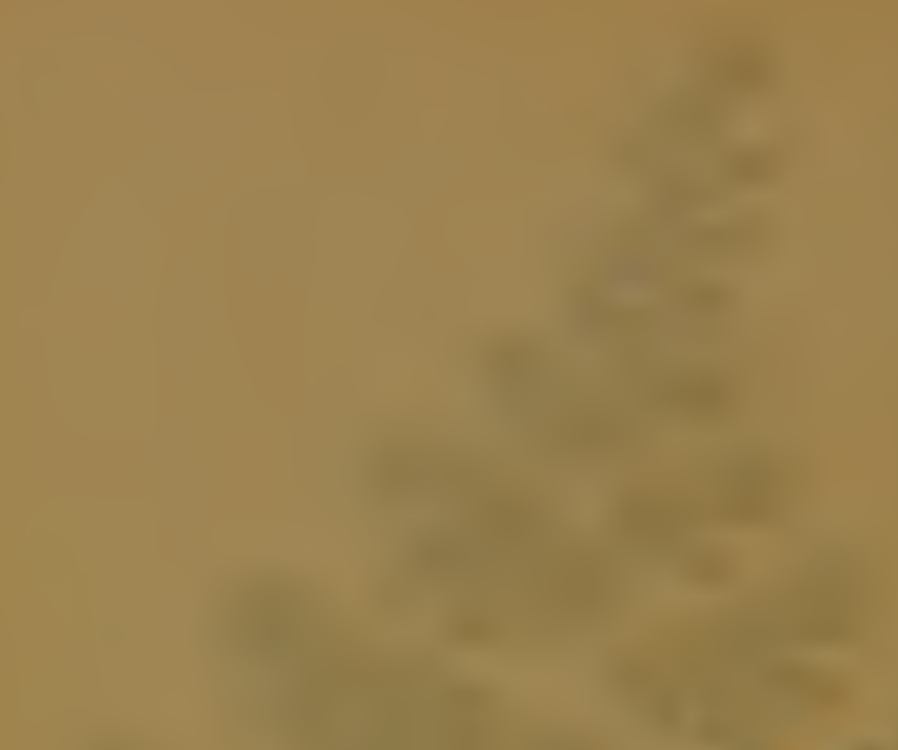
$\log x^{2}+2$

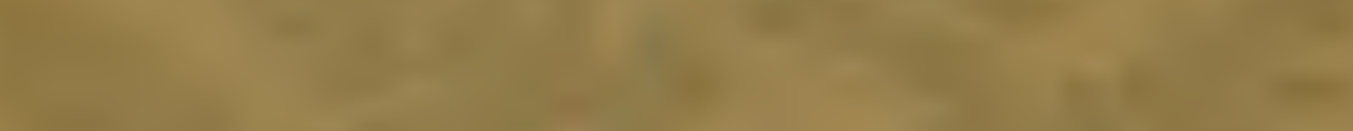

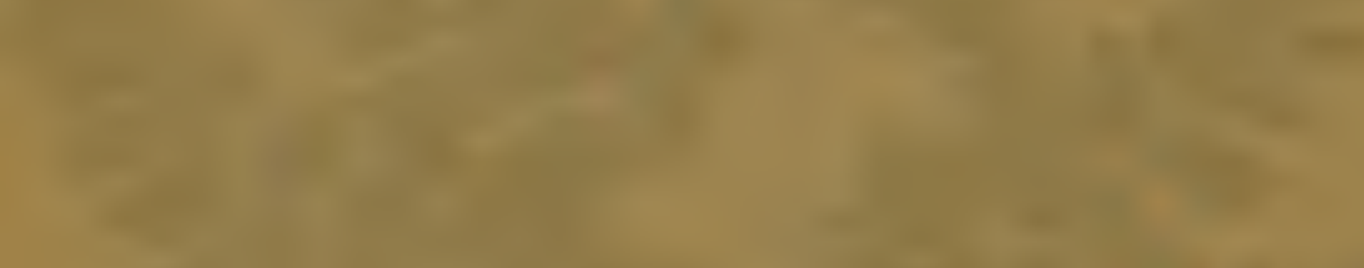

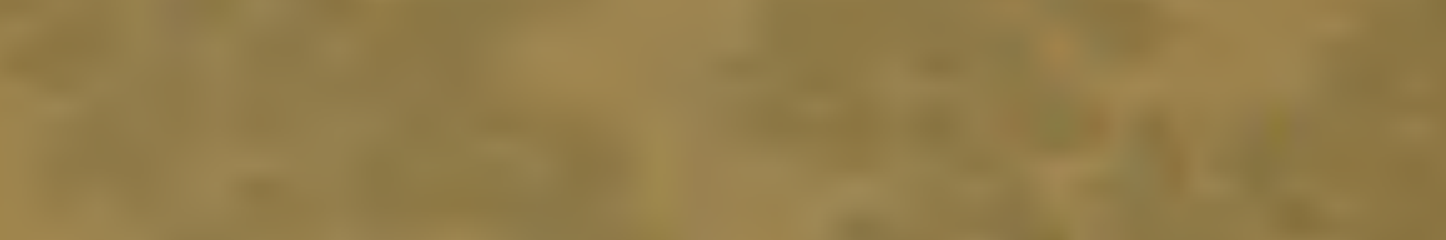

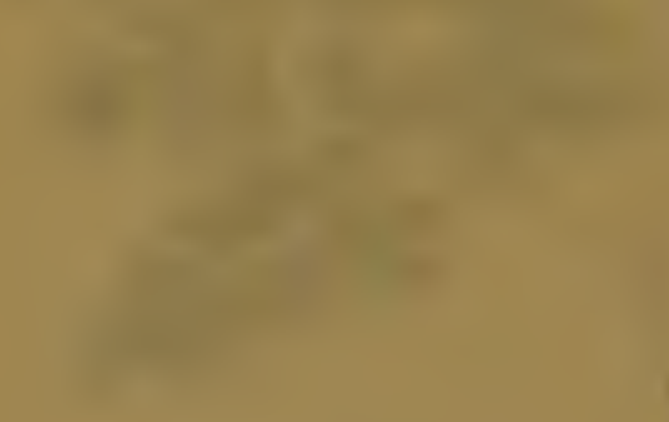
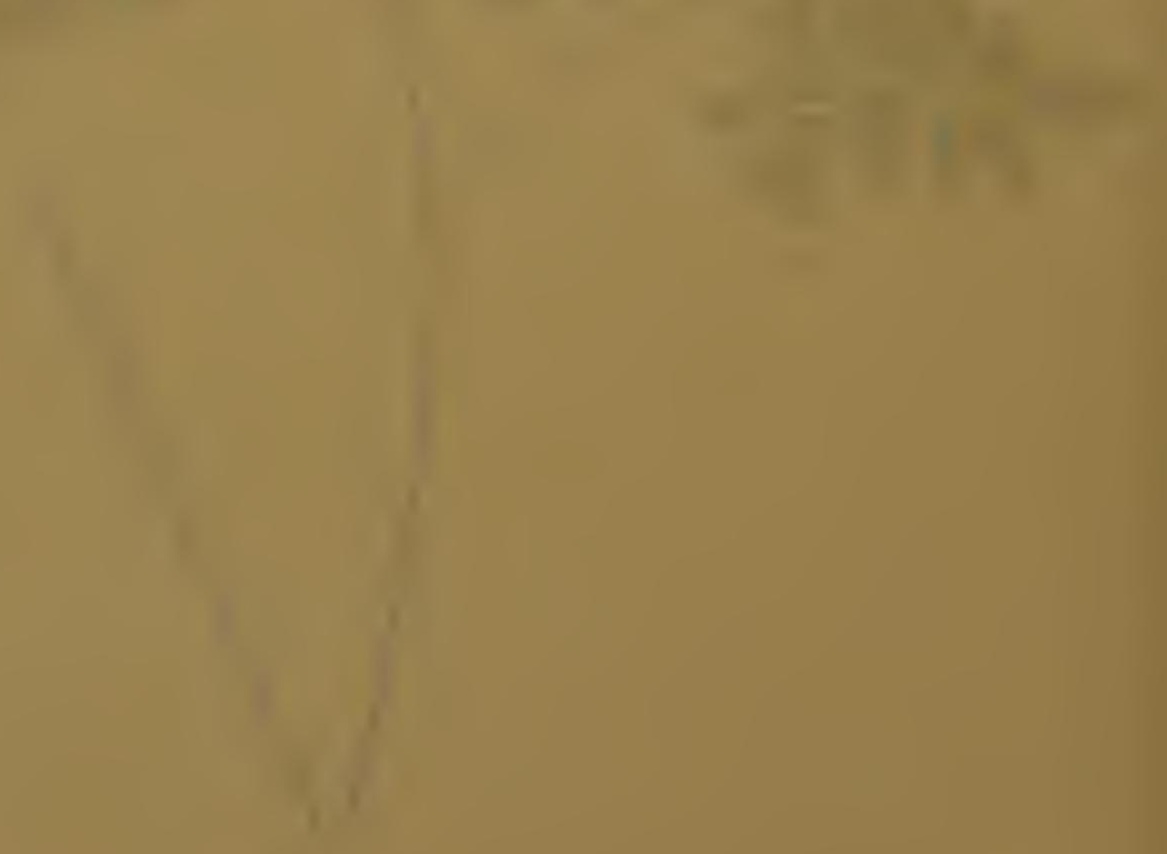


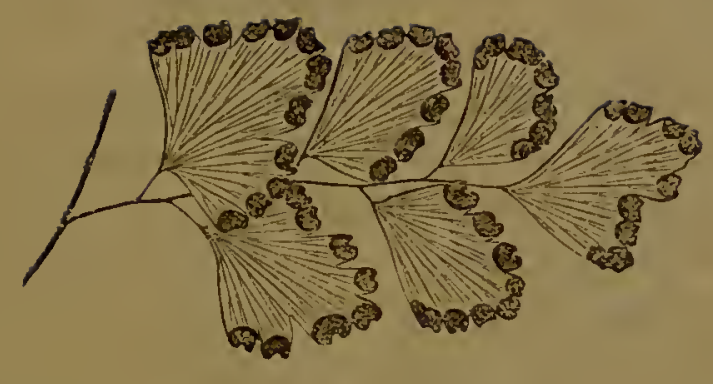

Portion of inittire Frond-under side.

\section{ADIANTUM TENERUM.}

Swartz. Hooker. Plumier. J. Simth. Presi.

MoOre and Houlston. Link.

Willdenow. Plunkenet. Fee, not Schiulr.

PLATE X. VOT. IIT.
Adiantum ussimile,
LiNk, not SWARTz.
" formosissima,
Royal Botanical Gardens, Berlin.
Of Gardens.
Adiantum-Dry.
Tenerun-Tender.

The Adiantum tenerum is a splendicl species when well grown, forming itself into a large yet elegant specimen, and well adapted for horticultural cxhibitions. 'The finest cxample I have crer seen, was grown in a pine stove, at the Kiddleston Gardens, by Mr. Jackson, gardener to Lord Scarsdale. 'This successful cultivator of plants, descrves the greatest praise for the masterly manner in which he has succeeded in growing this beautiful Fern.

An erergreen stove species.

Fronds glabrous, and branching thrce or four times; pinnate; the pinnules being membranous, rhomboidal, obtusc, incisoVOL. III. 
lobate; sterile lobes serrulate, the fertile ones entire. The pinnules are petiolate, the base being unequally euncate.

Sori oblong-reniform and numerous, from ten to thirteen on a pinuule.

'The length of the firond from eighteen inche's to three feet, nearly two thirds of which is naked. Stipes and rachis cheneous and glossy, the polished black stem extending cren to the foot-stalk of the pimules, and this produces a great contrast to the brilliant green of the pinnules. The frond is lateral, being attaehed to a short crecping rhizoma.

'There are several varietics of $A$. tenerum; in one the pinnules are shorter, and in another form they are larger.

It is a native of the West Indies, Central Ameriea, Guadaloupe, the West Indian Islands, Cuba, St. Vinecut, Bahamas, Antigua, Acapuleo, Realego, Veraguas, and Jamaica.

It appears to have been introduced into England as long ago as 1793.

My thanks are due to Mr. Parker, of the Paradise Nurserr, Holloway; and to Mr. Lamb, gardener to F. Wright, Esq., of Osmaston Minnor, for plants of this species; and to Mr. Jackson, gardener to Lord Searsdale; and to Mr. Norman, of Hull, for fruetified fronds.

It is in the Catalogues of Sim, of Foot's Cray; Rollisson, of Tooting; Veiteh, of Exeter; Lucombe, Pince, and Co., Excter; and A. Henderson, of Pine-apple Place.

The illustration is from a plant in ny own possession. 



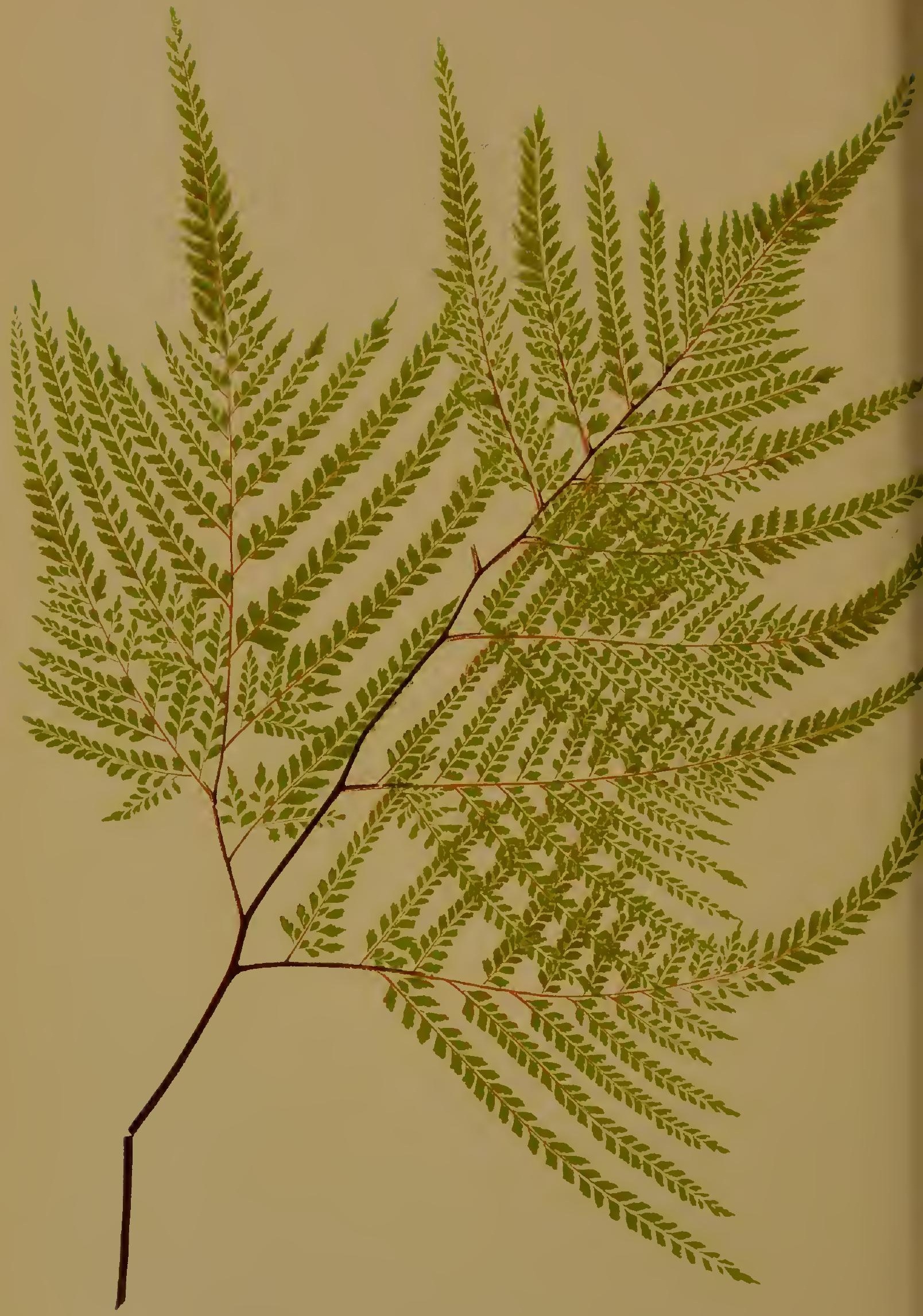




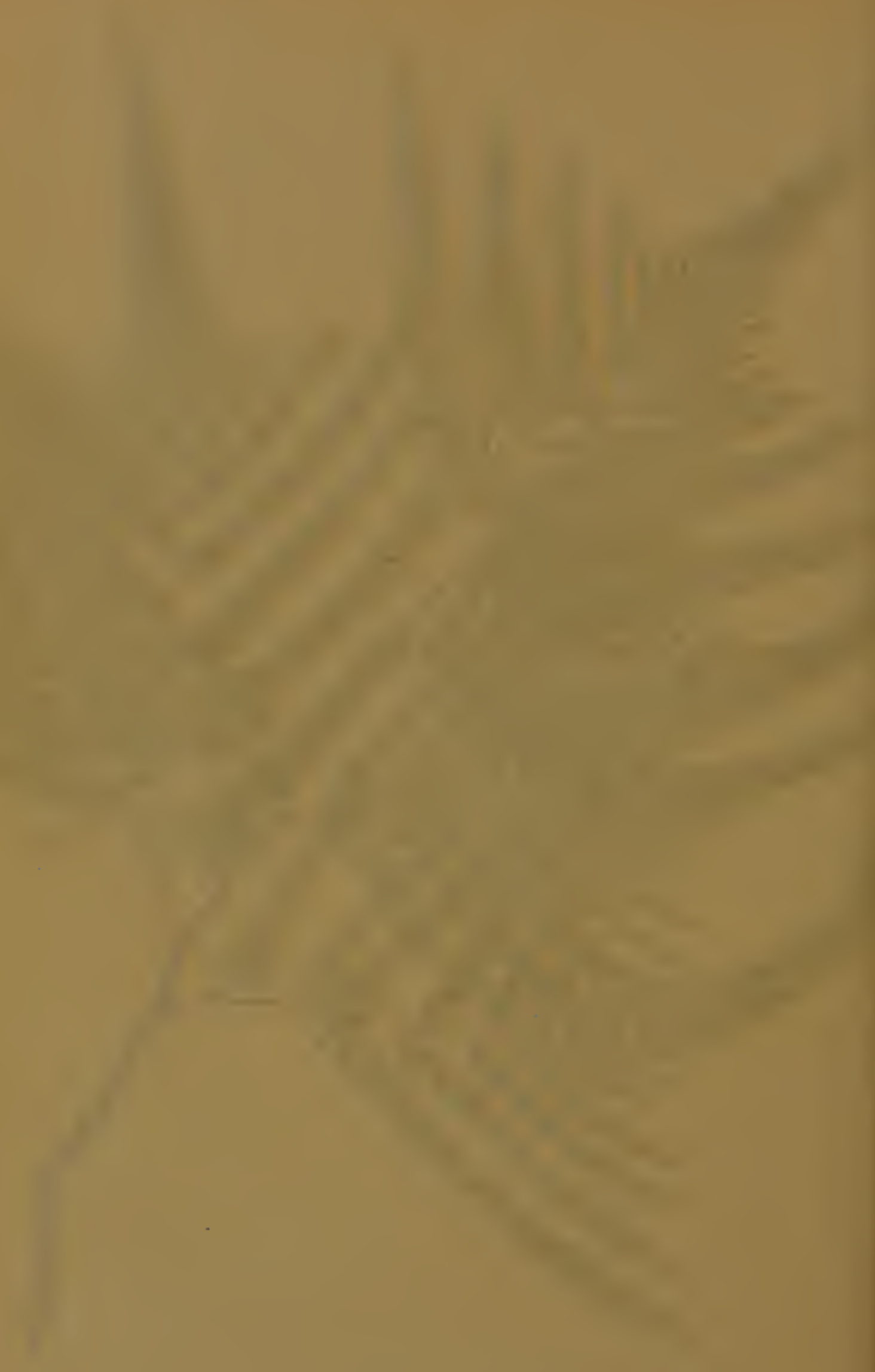

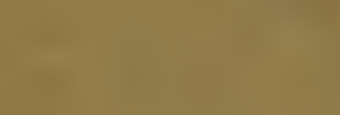

$-4 \div$ 


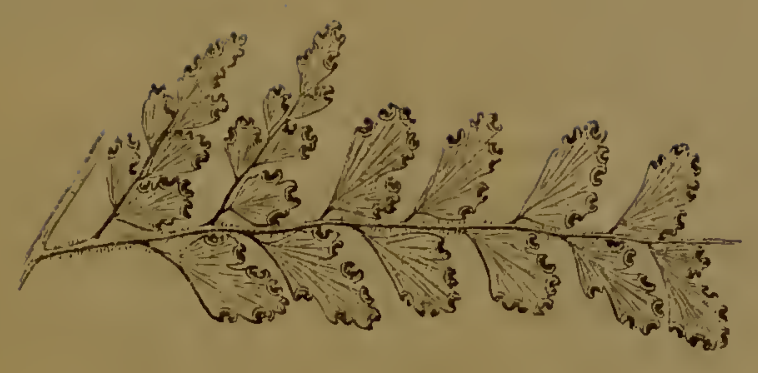

l'innule of mature Fiond-uncier side.

\section{ADIANTUM FORMOSUM.}

R. Brown. Hooker. Fee. Kunze.

J. Smitil. Presl. Moore and IIoulton. Link.

PI.ATE XI. VOI, III.

Adiantum-Dry. Formosum-Beautiful.

'L'His beautiful Adiuntum attains a large size under proper' cultivation, indeed no Fern morc clearly points out superior skill in the management of this tribe of plants than this species. It is a greenhouse Fern, yet when cultivated in stove-heat, becomes a larger and in all respects handsomer specimcn. Although a well known, and not to be mistaken species with our botanists, it is nevertheless found in our greenhousc collections uncler varions nanes, such as affine, tenerum, pubesecns, yiganteum, eapillus-vcneris; the name Adiantum giganteum must be a gardener's name, for I have not becu able to find it in any botanical work. With regard to the other nanes, they are those of perfectly distinet Ferns.

It appears to have been introduced into the Royal Giadens, Kew, in the year 182:3, by the indefatigable botanist A. Cunninghian, Esq.

A Now llolland fern, being rery common in the neighbourhood 
of Port Jackson, yet never found clsewhere, with the solitary exception of Mangatainoka, (New Zealand,) where it was discovered by $\mathrm{Mr}$. Colcnso.

$\Lambda$ common and casily cultivated species.

A. formosum is an evergrcen Fern with branching fronds, four times pinnate. 'The pinnules arc small, membranous, rhomboidal, blunt, inciso-lobate, sterilc, scrrate. Rachis pubescent; stipes long, scabrous, latcral, ebencous, and glossy, as well as the petioles; this contrasts greatly with the vivid grecn of the pinnules.

Sori small, with an oblong kidney-shaped indusium, usually about six on each pinnulc.

The height of the frond varies from eightecu inches to threc fect; one half of which is naked. The colour palc green. The rhizoma is slender and crecping.

It is a specics very readily propagated by spores, and also by divisions of the creeping rhizoma; in short no care is requisite with its propagation, as it is almost ccrtain for secdlings to spring up amongst the diffcrent plants in the house in which it is cultivated.

I am indebted to $\mathrm{Mr}_{\mathrm{r}}$. Lamb, gardcner to $\mathrm{F}$. Wright, Esq., of Osmaston Manor, for plants of this species; and to Mr. Henderson, of Wentworth; and to Mr. Norman, of Hull, for fructified fronds.

It is in the Catalogucs of Messr's. A. Henderson, of Pinc-apple Place; Lucombc, Pince, and Co., of Excter; Veitch, of Exeter; Masters, of Canterbury; Parker, of Holloway; Rollisson, of Tooting; E. G. Henderson, of St. John's Wood; Sim, of Foot's Cray; Booth and Son, of Hamburg; and Cooling, of Derby.

The illustration is from a plant in my own collection. 



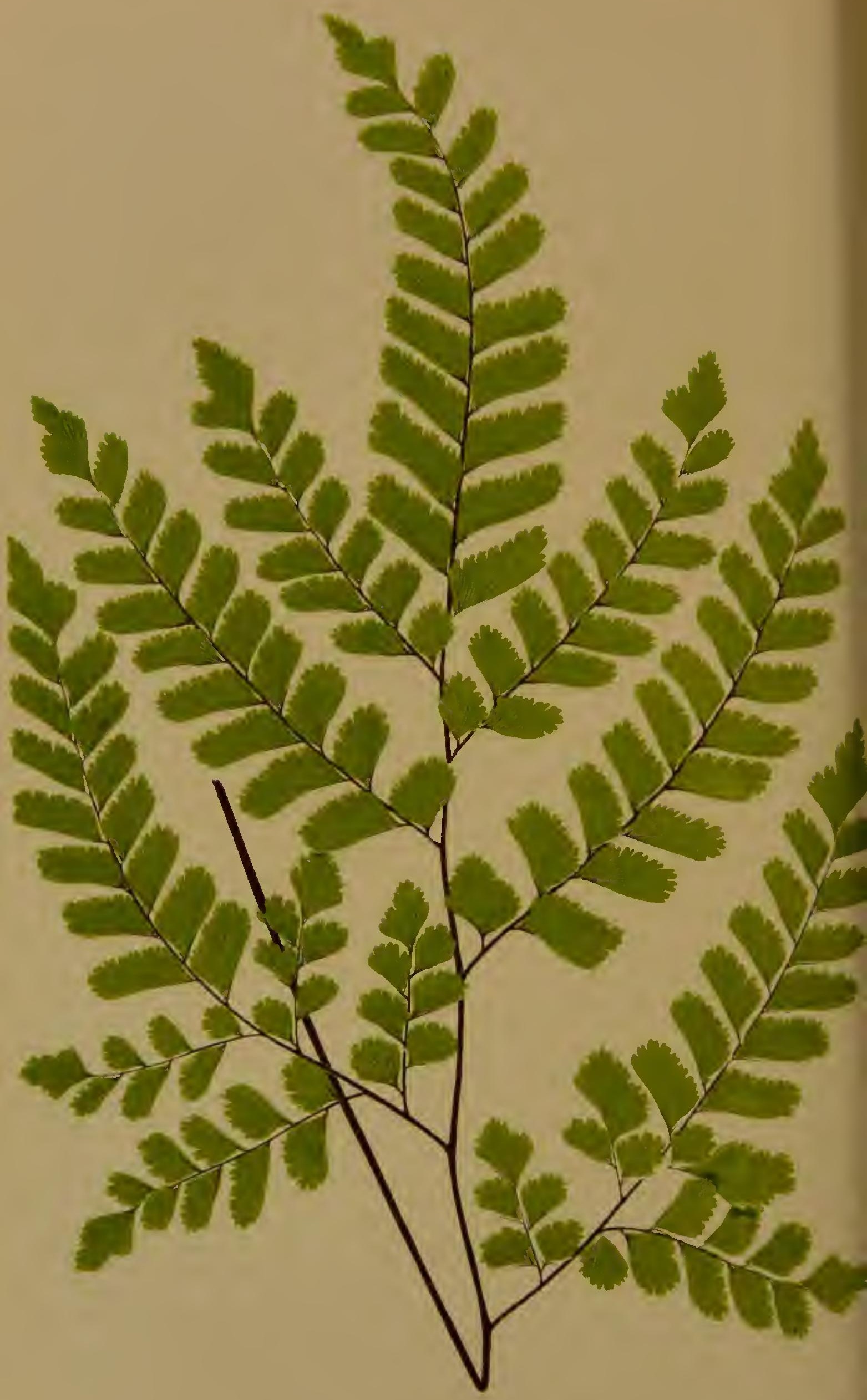




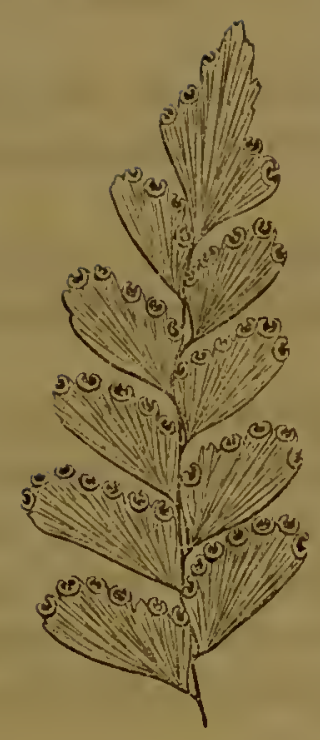

l'ution of mature Frond - under sille.

\section{ADIANTUM CUNNINGHAMI.}

Sir W. Hooker. Moore and Houlston. Fee. J. D. HOOLER.

PIATF XII. TOT. IIT.

Alliuntum formosum, " affine,

"

Adiuntum-Dry.
CUNATGTIM.

WilldeNow, nul HoOKER.

Moore. Of Gardess.

Ix the same group with Adiuntum cunninghami, are two other Ferns-the A. furmosum of Brown, and the $A$. fulcum of Raoul. Mr. Cunningham, the discoverer, scems to have referred the present Fern to the former of these species; yet, from Sir William I Iooker's description, they are sccmingly cach distinct. They are all natives of $\mathrm{New}$ Zcaland. Mr. Moore appears to Vol. III. 
think that the $A$. affine of Hooker, is the A. setulosum of $J$. Smith; and that $A$. cunninghami of Hooker, is the true A. affine of Willdenow.

An evergreen greenhouse Fern with glabrous fronds.

Discovered by Mr. Allan Cunningham, in the northern island of New Zcaland.

Bitripinnate to triquadripinnatc, pinnules rather small, dimidiate, oblong-obtuse, obliquely wedge-shaped at the base; superior inargin inciso-serrate.

Length of frond from twelve to fourtecn inches, width usually about seven inches; deep grecn in colour; half the stem naked. Stipes and rachis ebencous and glossy, stipcs covered with long red scalcs, which are larger and morc apparent near the base.

Sori numerous, seven to ten on a pinnule, indusium reniform, excecdingly pretty, being dark in the ccntre, and palcr-coloured round the edge.

Fronds lateral, attached to a scaly crceping rhizoma.

This desirable Fern is casily cultivated, and can be procured from Rollisson, of Tooting; E. G. Henderson, of St. John's Wood, Veitch, Jun., of Chelsea; Sim, of Foot's Cray; Parker, of Holloway; and Cooling, of Derby.

I am indebted to Mr. Ingram, of the Royal Gardens, Windsor; Mr. Moore, of the Botanic Gardens, Chelsea; and Mr. Mastcrs, of Cantcrbury, for plants; and to Mr. Norman, of Hull, and Mr. Henderson, of Wentworth, for fronds.

'The illustration is from a plant in my own collection. 
,
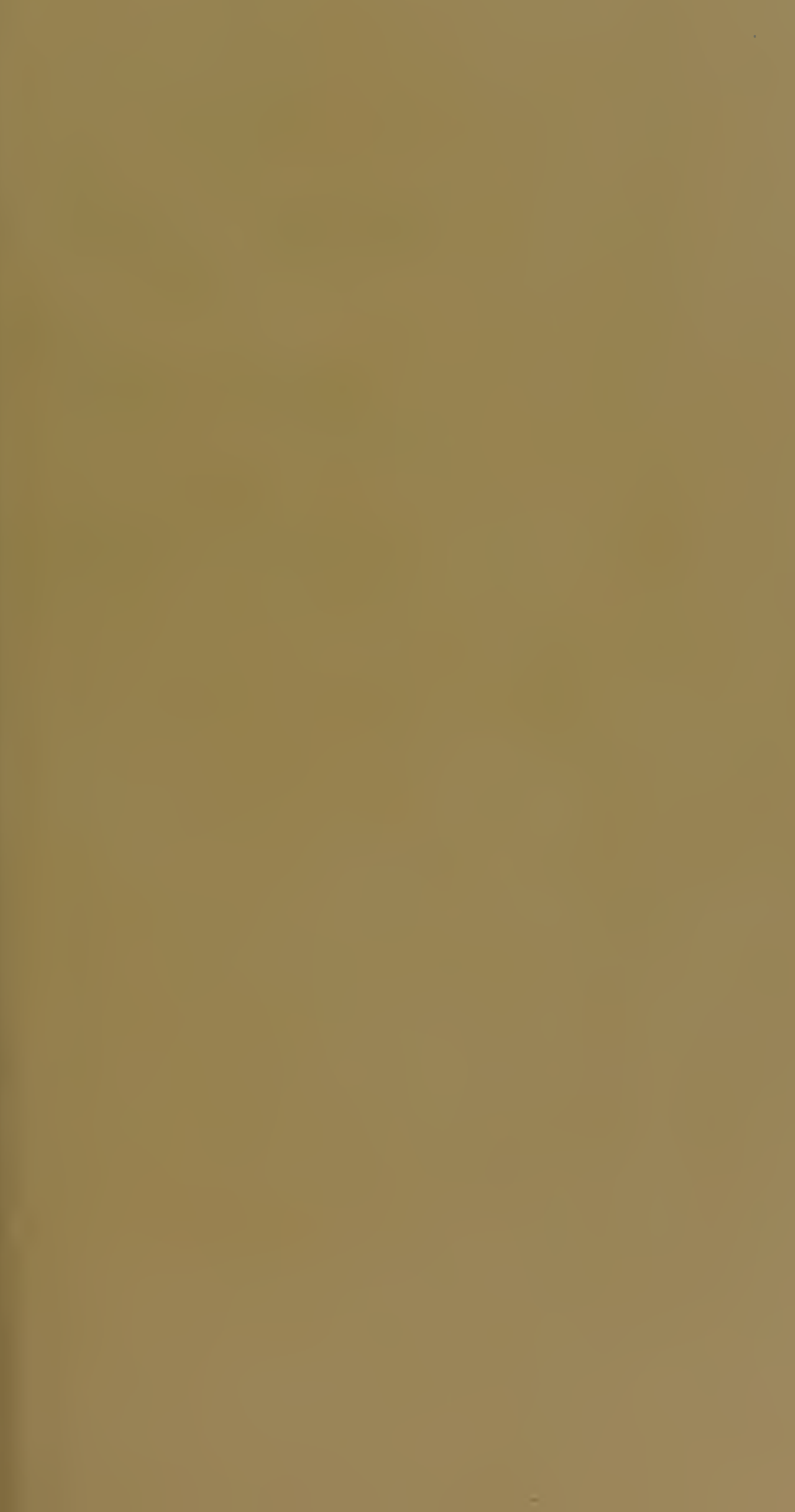


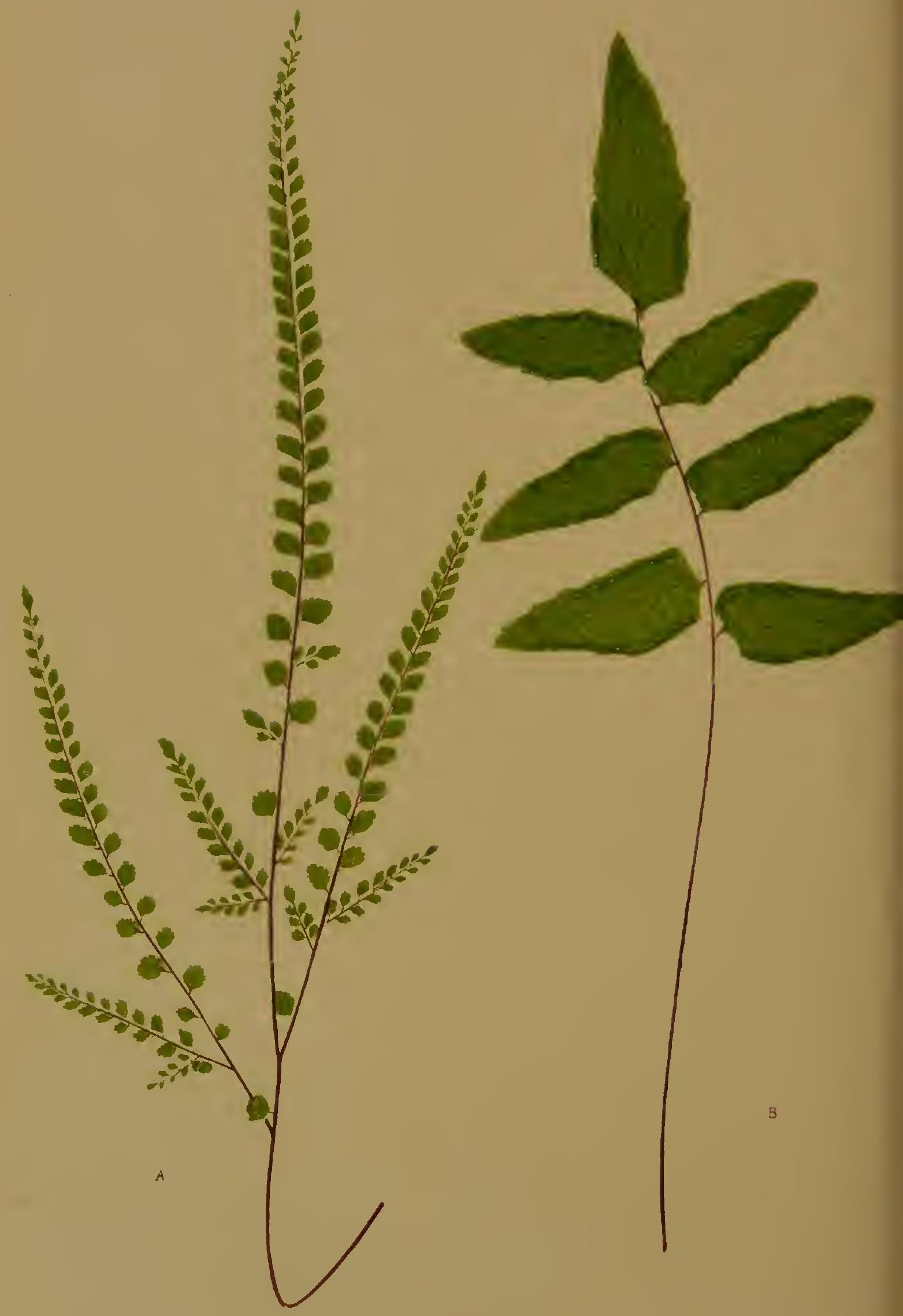




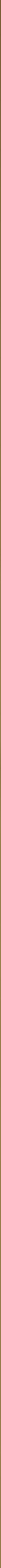




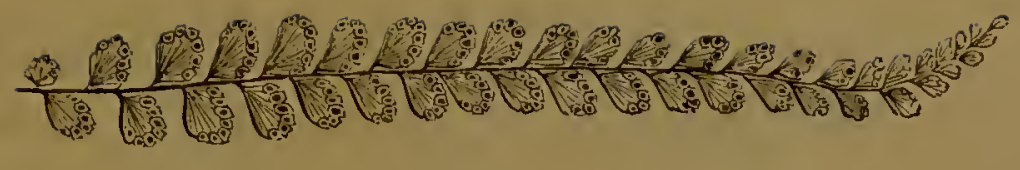

Portion of mature Frond-under side.

\section{ADIANTUM HISPIDULUM.}

Swartz. Moore and Houlston. R. Brown. Kunze.

J. Sмith. Fee. Hooker.

PLATE XIII. A. VOI., III.

Adiantum pubcscens, var.

Adiantum-Dry.
OF SOME Authors.

Hispidulum-Hairy.

This pretty dwarf Adiantum is not so universally eultivated as it deserves; oecupying but little spaee, and a readily procurable speeies from most of our principal Nurserymen, are recommendations, eoupled with its distinet appearance and easy eultivation, that should plaee this plant in the greenhouses of all Fern growers.

Sir William Hooker eonsiders the Adiantum pubescens as one of the forms of A. hispidulum; indeed, in looking over the extensive herbarium at Kew, it does appear that every transition from the present form to that of $A$. pubescens is there ineluded, in the fronds gathered in different countries and loealities. However, the more knowledge we obtain of the foreign Ferns, the more are we impressed with the eonvietion that our list of species is too much extended; in faet, it beeomes an execedingly diffieult matter, if not absolutely impossible, where to draw the line between speeies and varieties. Botanically speaking, this is an important question, as it is one means VOL. III. 
of pointing out the effect of climate and locality upon ccrtain specics; on the other hand, horticulturally speaking, the cultivator requires a name by which to recognise a plant; and if, as in the present instancc, that name be A. hispidulum, it matters but little whether it be a distinct spccies, or merely A. pubescens, var. hispiclulum. What the cultivator requircs is a correct knowledge of the names of the plants that he is growing, in order that he may be cnabled to name then properly. If a varicty happens to be constant in its peculiaritics, it is as valuable to him as a distinct species.

A greenhonse evergreen Fern.

Native of New Zealand and New Holland.

Introduccd into the Royal Gardens, Kew, in the year 1824, having been received from Mr. Allan Cunningham.

The form of the frond is bipinnate, the lower branches being bipartite, and above pinnate; the pinnules bluntly oblong, wedgeshaped at the base, and crenate on the margins; the branches small and slender.

The fronds, which are somcwhat hairy, are from five to eight inches in length; dark green in colour, the venules marking the frond on the upper surfacc, and giving it a rough appearance.

Sori small, indusiun reniform, from six to eight on a pinnule.

Fronds lateral, attached to a crecping slender rhizoma. Pinnules vcry small, and having scarcely any petiole. The young fronds are much paler in colour.

Plants have bcen received from Míessrs. A. Henderson, of Pine-apple Place; Messis. Rollisson, of 'looting; Masters, of Canterbury; and Veitch, of Chelsca.

It may bc procured at a moderate price at any of the following Nurseries:-A. Henderson, of Pinc-ipple Place; Masters, of Cantcrbury; Parker, of Holloway; E. G. Henderson, of St. John's Wood; Rollisson, of 'looting; Sim, of Foot's Cray; Veitch, Jun., of Chelsea; Booth, of IIamburg; Osborn and Son, of Fulham; and Cooling, of Derby.

'The illustration is from a plant in my own possession. 


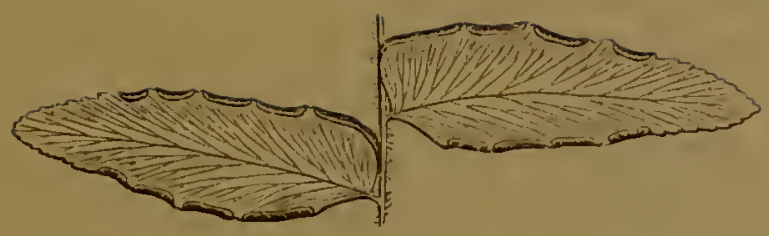

Portion of mature Frond- under side.

\title{
ADIANTUM OBLIQUUM.
}

\section{Whlldenow. Hooker. Sprengel. Klotzsch. Moore and Houlston.}

PLATE XIII.-B. VOI. III.

\author{
Adiantum lucidum, \\ SWART\%. \\ Ptcris lucida, \\ Cavanilles.
}

Aäiantum-Dry. Obliquum-Oblique.

As interesting Maidenhair, of dwarf eompact habit, and probably race in cultivation in this country. From the deseription of this Fern in Sir William Hooker's "Species Filicum," we find that a number of botanists have notieed the Adiantum obliquum in its native habitats, among these, Bredemeyer, Sir R. H. Schomburgk, Dr. Klotzsch, Le Prieur, R. Spruee, and L'Hermonnier, all found it growing wild.

An evergreen stove speeies.

Introdueed into England in the year 1826.

A native of the West Indies and South Ameriea, Porto Rico, Caraccas, British Guiana, Columbia, Montague de Mahurie, ('anemne, 'Tanaii, and Guadaloupe.

An oblong pinnate frond, pinnic on short petioles, ovate-oblong, acuminate, the margin on upper base truneate and parallel with the rachis, the lower margin dimidiato-euneate. 
Fronds glabrous, twelve inches long, upper surface dark grecn, bencath glaucous.

Sori numcrous, from fourteen to sixtecn on a pinnulc, oblong, linear, extcnding along both the upper and lowcr margin to the apex.

Stipcs and rachis rough, bcing covercel with ferruginous down.

The frouds, which are mostly fertilc, are lateral, rising out of a creeping rhizoma.

A variety is in cultivation in which the pinnæ are longcr and more pointcd.

Mr. Parkcr, of Holloway, includes this Fern in his Catalogue.

No plant has been forwarded to me up to the present date, my thanks are, however, due to Sir William Hooker for fronds. The illustration is from a frond forwarded by Sir William Hooker. 


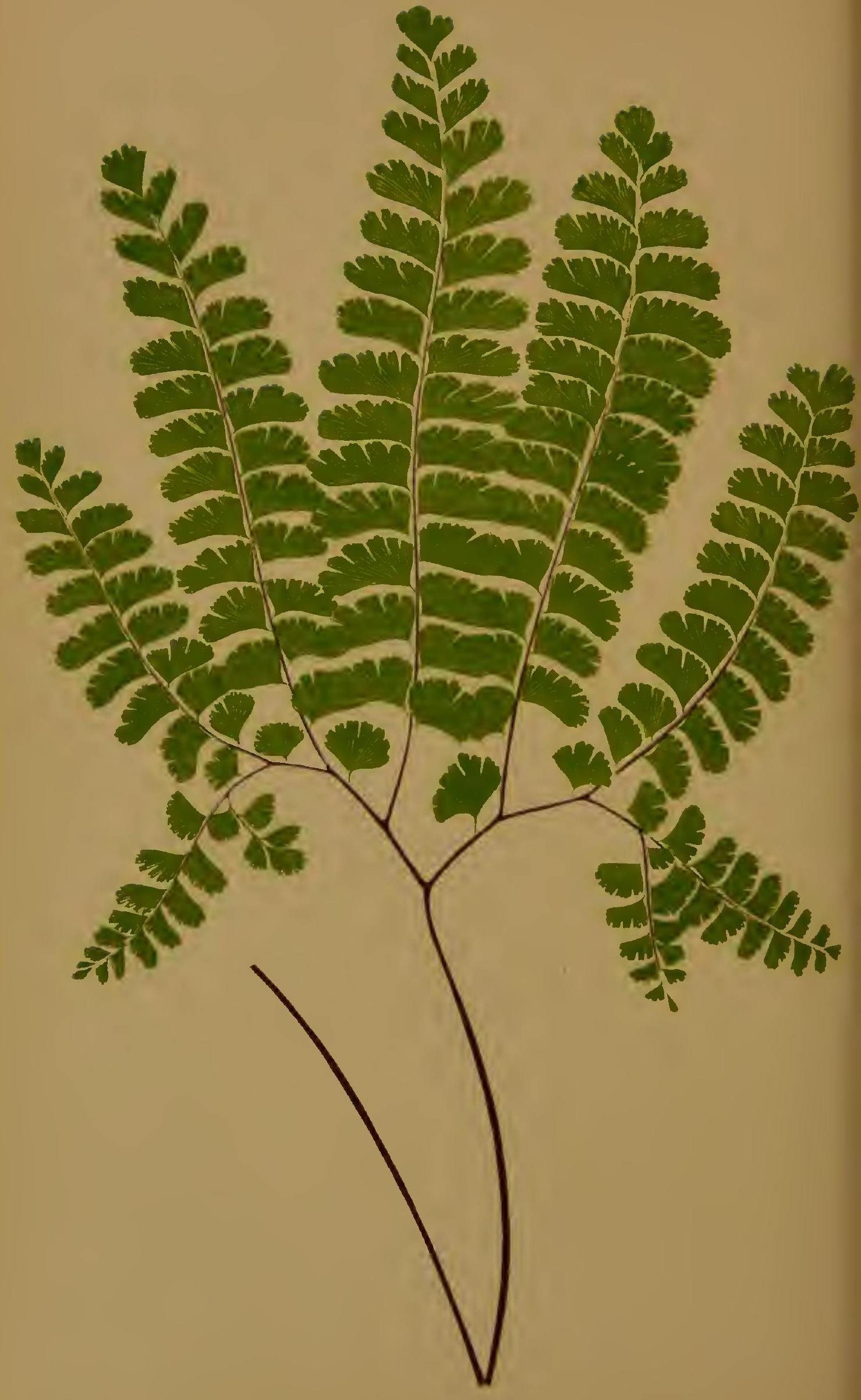




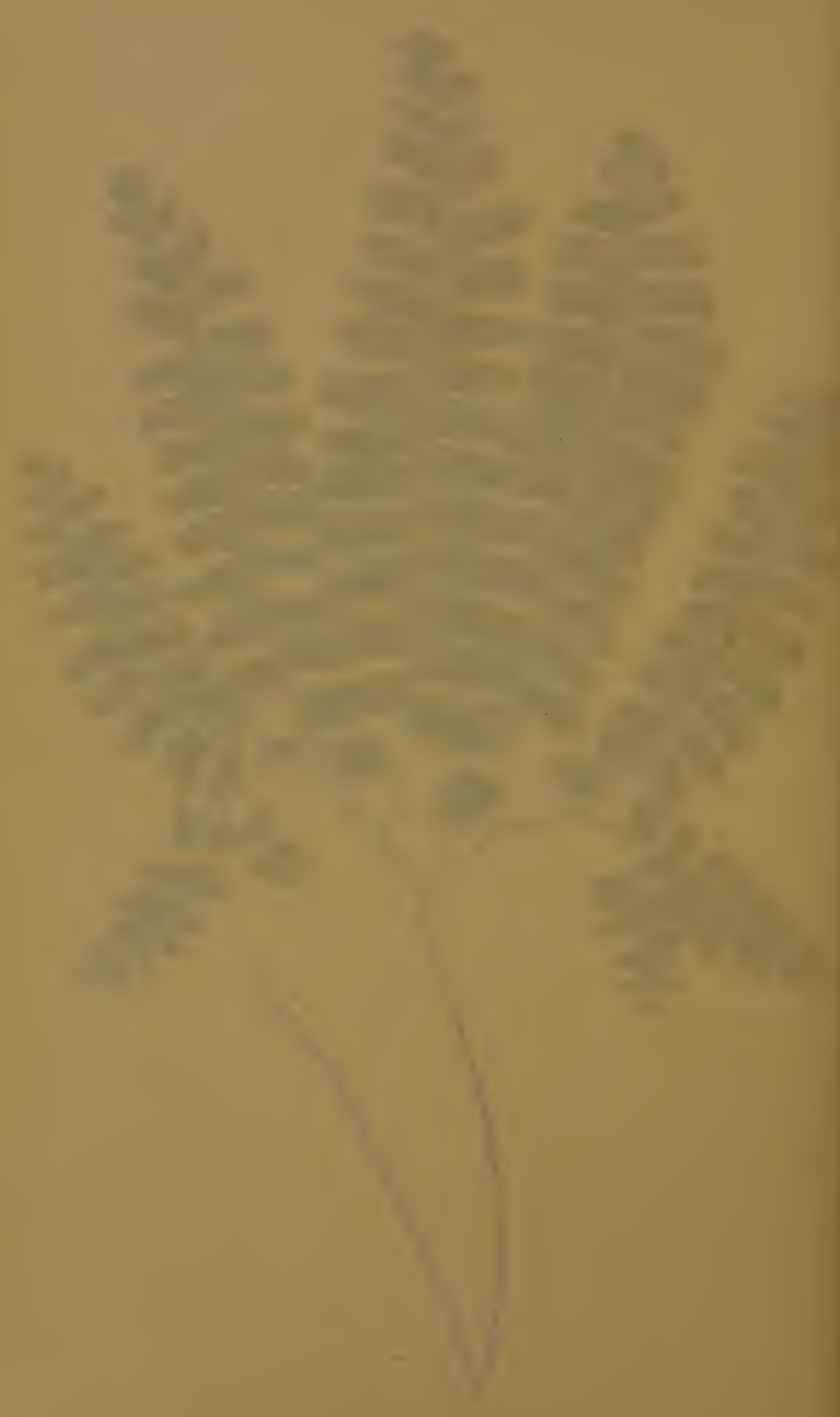




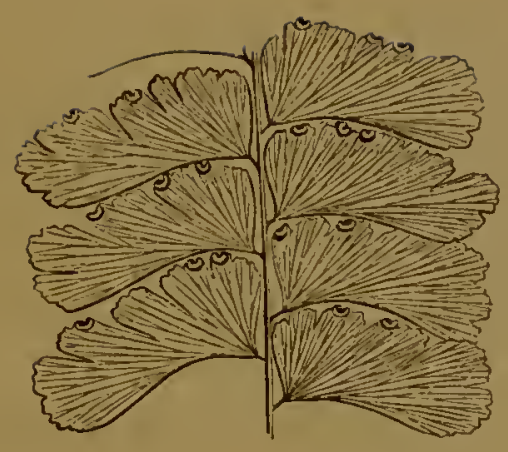

Portion of mature Frond-under side,

\section{ADIANTUM PEDATUM.}

Linneus. Kunze. Swartz. Hooker. J. Smith. Schkuhr. Sprengel. Whlldenow. Kaulfuss. Chamisso. Fel. Moore and Houlston. Presl.

PI,ATE XIV. TOI. III.

Adiantum boreale,

Adiuntum-Dry.
Prest.

Pedalum-Pedate.

A userur and ornamental Fern, bcing cqually at home in the open Fernery, or in the stove or greenhouse. It is the most liardy of the Adiantums, and in this elimate can withstand a cold that would be ccrtain death to the British Adiuntum capillus-veneris. In this neighbourhood in January, 1854, plants lived out of doors, with the temperature $6^{\circ}$ below zero of Fahrenheit's thermometer, whilst near them the same cold killed all the plants of $A$. capillus-veneris. 'The young fronds are delieate, and, coming up early, those first appearing are not unfrequently eut with spring frosts.

Although so hardy a Fern, still, like the other Adiantums, VOL. III. 
it never grows so luxuriantly out of doors, as it does in storcheat.

Introduced into the Royal Gardens, Kcw, in the year 1809 , but probably known in England as early as 1640 .

A hardy deeiduous Fern, growing in shady woods.

Native of North America, from Virginia to Canada, California to Sitka; Unalaschka, and Northern India; about Kamoun, according to Dr. Wallich; and at Jumnotri, according to Dr. Cantor.

Presl considered the Indian Fern distinct from the North Amcrican one, yet thcre secms to be no real difference.

The fronds, which are glabrous, are pedate, the branches being linear; pinnate, pinnules membranaccous, dimidiate, oblongobtusc, cuneate at the base, the upper margin being lobate, or broadly erenate.

Fronds latcral, on a short erceping rhizoma.

Sori oblong, solitary.

Stipes, and rachis ebcneous.

Length of frond from twelvc to cighteen inches; colour a delicate grcen.

For plants of this species I am indebtcd to Mcssrs. Rollisson, of Tooting; the Rev. J. Robinson, of Widmerpool, Nottinghamshire; and for fronds to Mr. Norman, of Hull; Mr. R. J. Gray, of St. Thomas', Exetcr; and to Mr. J. Henderson, of Wentwortl.

It is in the Fern Catalogues of Messrs. A. Henderson, of Pine-apple Place; Rollisson, of Tooting; Parker, of Holloway; Cooling, of Derby; Kennedy, of Covent Garden; Sim, of Foot's Cray; Bass and Brown, of Sudbury, Suffolk; Masters, of Cantcrbury; E. G. Hcnderson, of St. John's Wood; and Osborn and Sons, of Fulham.

The illustration is from a plant in my own collection. 



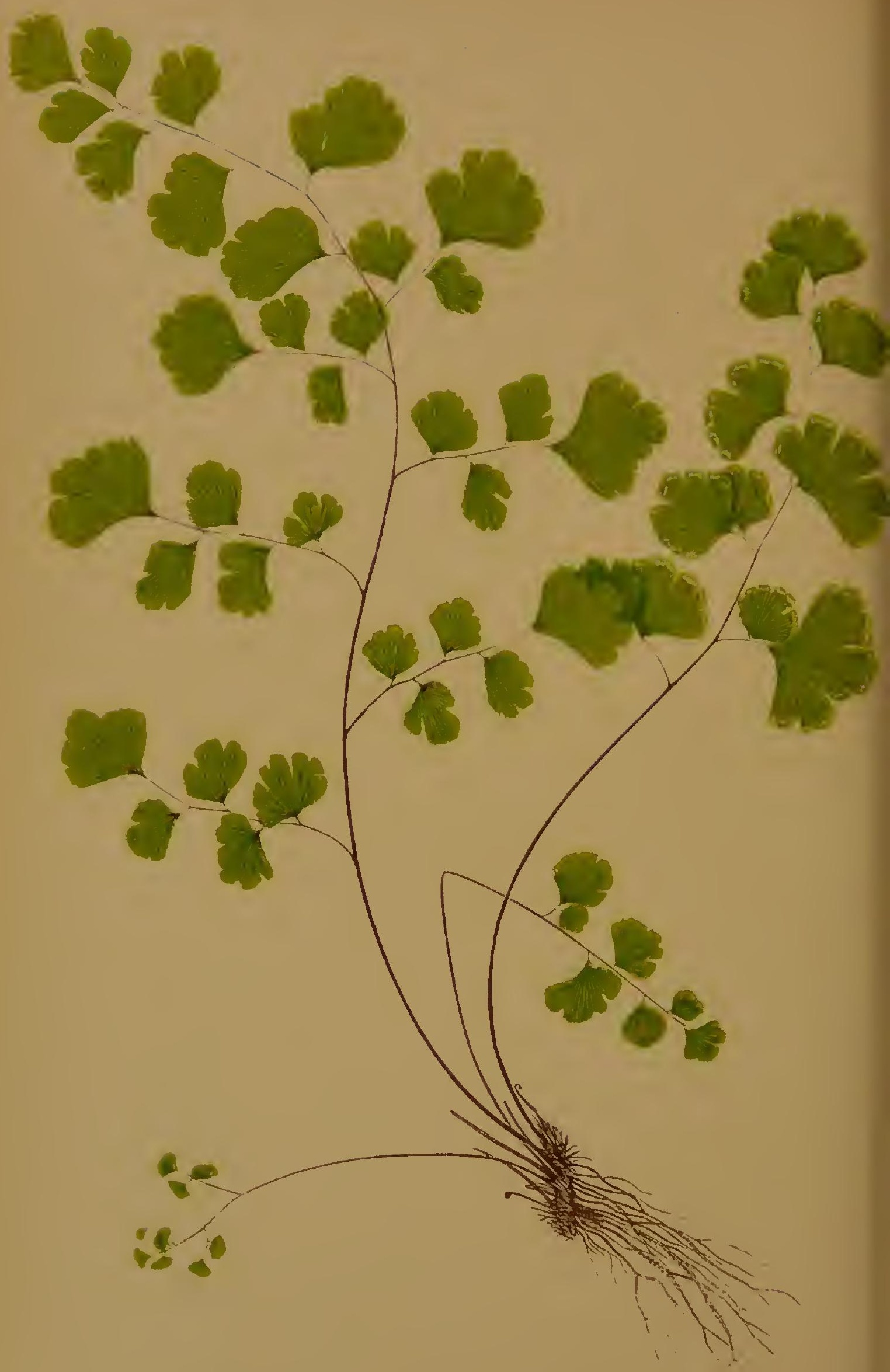




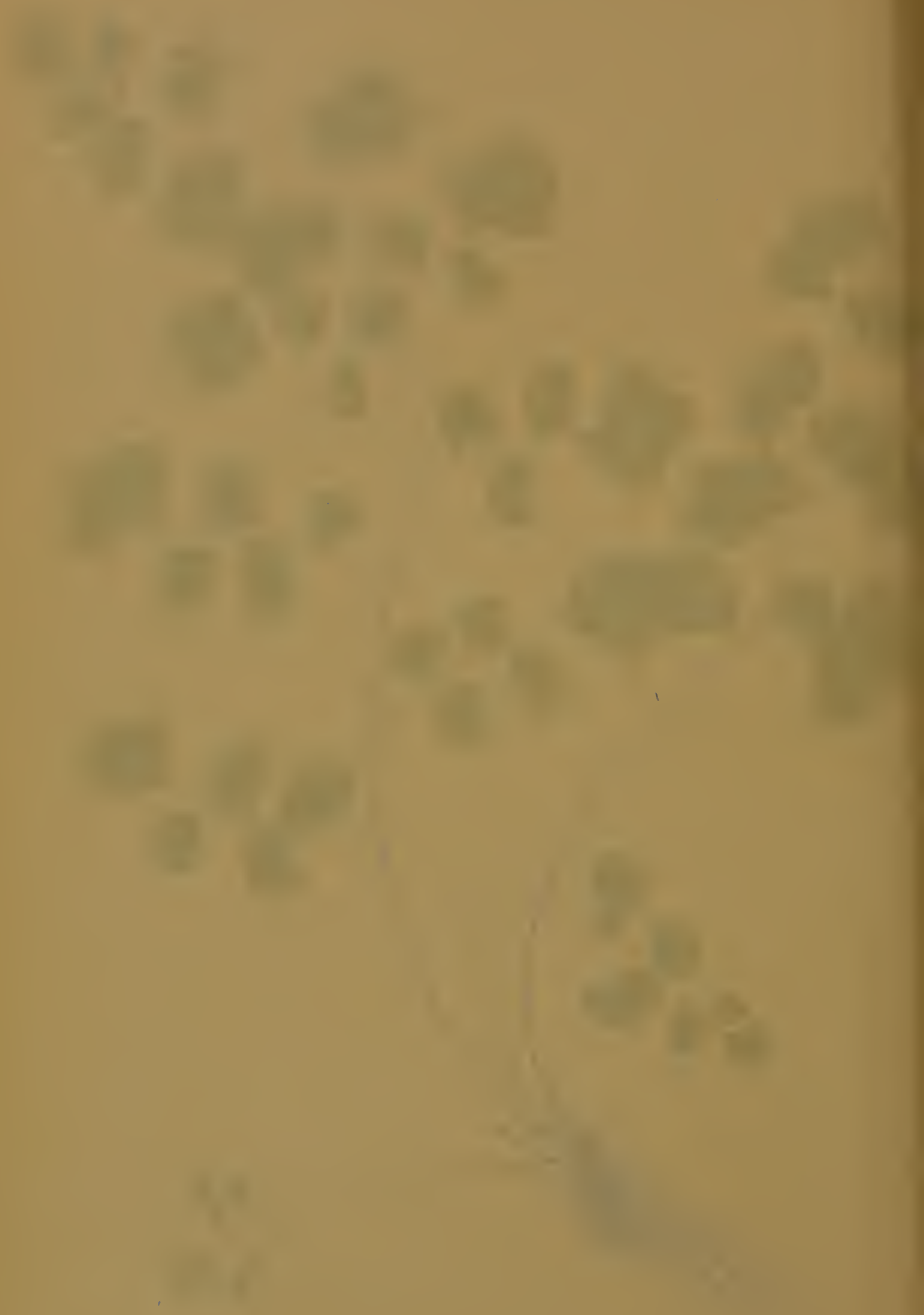




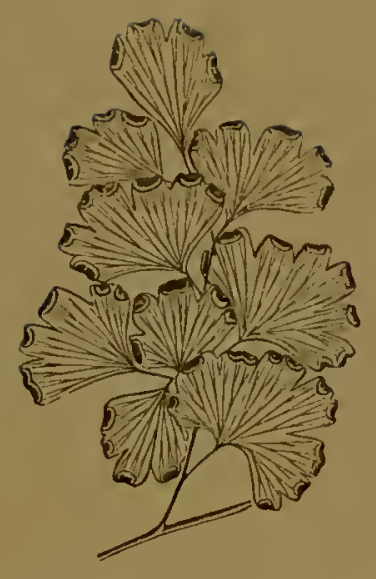

Portion of mature Frond-under side.

\section{ADIANTUM CAPILLUS-VENERIS.}

Linneus. Bolton. Shith. Hooker and Arnott. Babington. Mackay. Deakin. Newhan. Moore. Sowerby. Jacquin. Willdenow. Presl. Fee. Pratt. Hooker and Bauer. Francis.

PLATE XV. VOL. III.

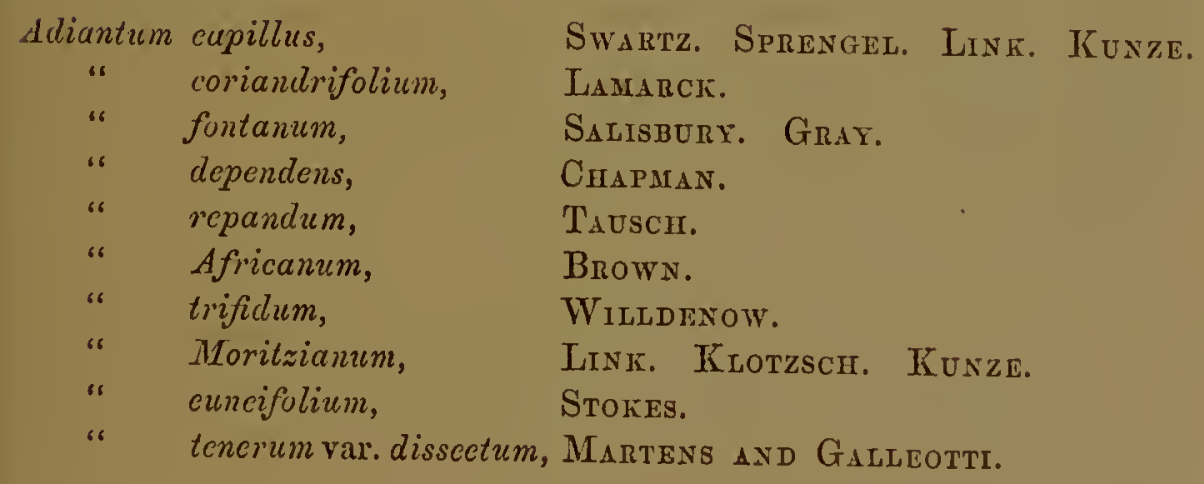

Adiantum-Dry. VOL. III.
Capillus-veneris-Trenus-hair.

II 
Trie "Common Maiden-hair Fern," as the Adiantum capillusveneris is more generally ealled, is the only British representative of this delientely beautiful family. Although a British Fern, still it grows mueh more luxuriantly under pot eulture than when planted out in the Fcrnery; a warm humid atmosphere, in a shady situation, being essential to its well-being. In its wild state it is found growing on rocks near the sca. Mr. Moore, in the "Nature-printed Ferns," has giren three beautiful illustrations, one from Ireland, another from Devonshirc, and a third from Cornwall; the last is from a cultivated plant which I received from Penzance, and which I forwarded to Mr. Moorc.

To grow this Fern properly, use abundant drainage and a light eompost of turfy peat, with the addition of lcaf mould, sand, and pieces of sandstone; the rhizoma should be kept on the surfaec of the soil.

Frost injures the "Maiden-hair Fcrn," and a severe frost will kill it; the great cold of 1853 destroyed all the plants in the Fernery at Highficld House. When grown out of doors it is deeiduous, and cven in a warm greenhouse it should have rest for several months in wintcr, or the plants will become wcak and sickly from the want of rest. 'Too much stress eamnot bc laid upon this essential with dcciduous Fcrns, as the umnatural forecd growth of winter only injures them.

A half-hardy deciduous native Fern, growing upon roeks and in eaves whore there is an abundant supply of moisture. It is never found except near the sca level.

The geographic range is eonsiderable, being found throughont the middle and south of Europc, France, in Asia, India, China, Persia, Arabia, Syria, Siberia, (Caucasus and Ural districts, ) Algicrs, Egypt, Cape of Good Hope, Mauritius, Bourbon, Madagascar, Algoa Bay, Florida, California, Guatemala, Mexieo, Texas, Parra, Caraccas, Trinidad, St. Tineent, Dominiea, Jamaica, Sandwich Islands, New Calcdonia, New Hebrides, and the Islands of the Mediterranean, 'Teneriffe, Madcira, Canaries, Cape de Verd, and Azores; England, Wales, Ireland, and Isle of Man and Channel Islands. Dr. Hooker describes the following Indian localitics:-Malabar, Ara, Nepal, Simka, Scinde, Khasiya, Bhotan, Assan, Sikkim-Himalaya, Cashnmcre, 'Thibet, Bchoochistan, Affghanistan, Kamaom, and Klasya.

In this country it is found in Cornwall at Sir C. Lemon's 
scat at Carclew, also at St. Ires and at Hayle; in Dcronshire, at Ilfracombe, Rillidge Point, Watermouth, and Brixham; in Glamorganshire, at Dumraven and Barry Island; in Somersetshire I found three plants growing in the fissurcs of roeks in an air slaft of a stone quarry at Comb Down, in the year 1849; sinee that time several persons have visited the loeality, and in $\mathbf{1 8 5 5}$ I myself went through the quarry a seeond time, but failed, like others, to detect any more plants. In the Isle of Man, in Glen Neay; in Ireland, in Galway, Arran Isles, Kerry, and Clare. It has been said to have been found in the counties of Stafford, Shropshire, Derbyshire, and York, and in Seotland at Argyle and Kincardine, yet these loealities require verifieation.

The fronds are generally of a lengthened triangular or ovate form, oecasionally laneeolate or oblong. They are membranaeeous, glabrous, sometimes bipinnate, at others tripinnate. Both the pinnx and pinnules are alternate. The pinnules differ mueh in form, they are rounded with a truneate base, being obliquely fan-shaped; mostly wcdge-shapcd at thc base, being attaehed to skort petioles.

Sterile lobes toothed on the edge, the fertile lobes blunt.

The veins are a eolleetion of diehotomous ramifieations, being radiately forked. Venules disunited at their apiees.

Length of frond from six to eighteen inehes; colour bright green.

Sori oblong, varying in length aecording to the width of the lobe. Indusium of the same form, membranaceous, and bearing the spore cases on its under surfaee.

Stipes and raehis ebeneous and polished, slender, purplish black in eolour, having a few seales near the base. Stipcs lateral.

Rhizoma erceping, dcnsely scaly, of a dark brown eolour. 'There are three varieties deseribed in the "Nature-printed Ferns:"-

1st. var. Multifidum, Wollaston.

2nd. var. Incisum, Moore.

3rd. var. Rotundatum, Moore.

A description of cach will be found in the before-mentioned work. Intcrmodiate forms necur, so as to run the different forms into each other.

B3y some authors A. Moritzicmum is eonsidered a distinet 
species, yet as it varies only in its increased size, no doubt from inhabiting a warner atmosphere, it is rery cloubtful whether it be really distinct.

Introduced into the Royal Gardens, Kcw, in the year 1793.

From this plant Capillaire is made.

My thanks are dne to the following for plants of $A$. capillusveneris :-Mr. Henderson, of Wentworth; Mr. R. 'T. Millett, of Penzance; Mr. J. Sidebotham, of Manchester; Mr. Jackson, (gardener to Lord Scarsdale,) of Keddleston, Derby; Mr. Booker, of Matlock; Messrs. Rollisson, of Tooting; and for the form of A. Moritzianum to Mr. Menderson, of Wentworth; and for Irish plants to Mr. G. Allcock, Jum., of Nottingham. For fronds I am indebted to $\mathrm{Mr}$. Norman, of $\mathrm{Hull}$; and to $\mathrm{Mr}$. Gray, of St. 'l'homas', Exeter.

It is in the Catalogues of Messr's. Veitch, Jun., of Chelsca; A. Henderson, of Pine-apple Place; Booth and Son, of Hamburg; Parker, of Holloway; Kennedy, of Covent Garden; Sim, of Foot's Cray; E. G. Henderson, of St. John's WVood; Teiteh, of Exeter; Osborn, of Fulham; Rollisson, of Tooting; Bass and Brown, of Sudbury, (Suffolk;) Mastcrs, of Canterbury; Pearson, of Chilwell; Mackintosh, of the Botanic Gardens, Madeira; and Cooling, of Derby.

'The illustrations are from my own plants, and from others sent by Mr. Gray, of St. Thomas', Exeter. 


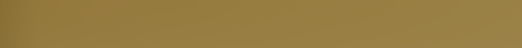

- 





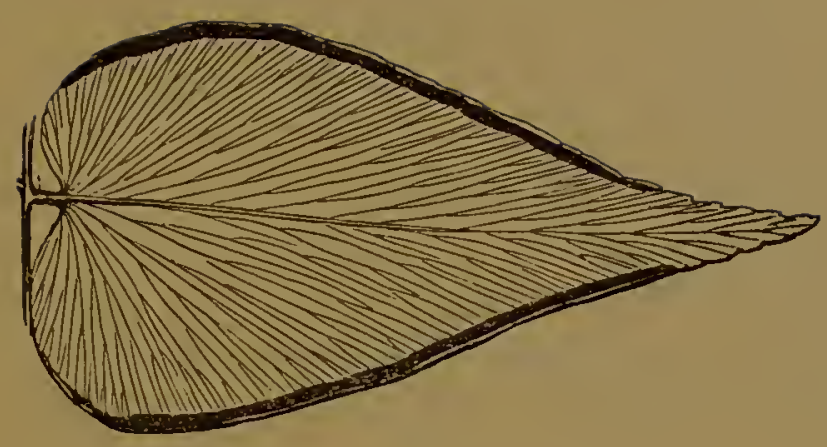

Portion of mature Frond-under side.

\section{ADIAN'TUM WILSONI.}

\section{Hooker. Moore and Houlston.}

PIAATE XVI. VOL. III.

Hewardia wilsoni,

Adiantum-Dry.
Suith.? Fee.

Wilsoni-Wilson's.

A singular and delieate Ferm, diseovered in dry, shady, gravelly places in Jamaica, by Mr. Wilson, the Curator of the Bath Botanie Gardens, Jamaiea, and named by Sir W. Hooker, after this botanist. It is a very distinet speeies.

\section{An evergreen stove Fern.}

Only found in Jamaica.

Fronds glabrous, pinnate, the pinnæ somewhat ovate, petiolate, alternate, eaudate at the base, coriaeeous; the sterile fronds serrate at the margin, petiolate. Three to five pinnæ on a frond. Costa ebeneous at the base. Veins forked and anastomosing. Stipes and raehis ebeneous and glabrous.

Sori linear, being eontinuous on both margins nearly to the apex.

VOL. III. 
Fronds lateral, adherent to a creeping rhizoma.

Length of frond twelve inches. Colour of frond dark green above, paler beneath. The stcrile fronds broader.

A difficult Fern to grow successfully, requiring much care, and a porous stony soil.

It can be procured from Messrs. Rollisson, of Tooting; and Mr. Sim, of Foot's Cray.

My thanks are due to Mr. Sim, of Foot's Cray, for a plant; and to $\operatorname{Sir} \mathrm{W}$. Hooker, and to Mr. Sim, for fronds.

'The illustration is from a frond sent by Sir W. Hooker. 



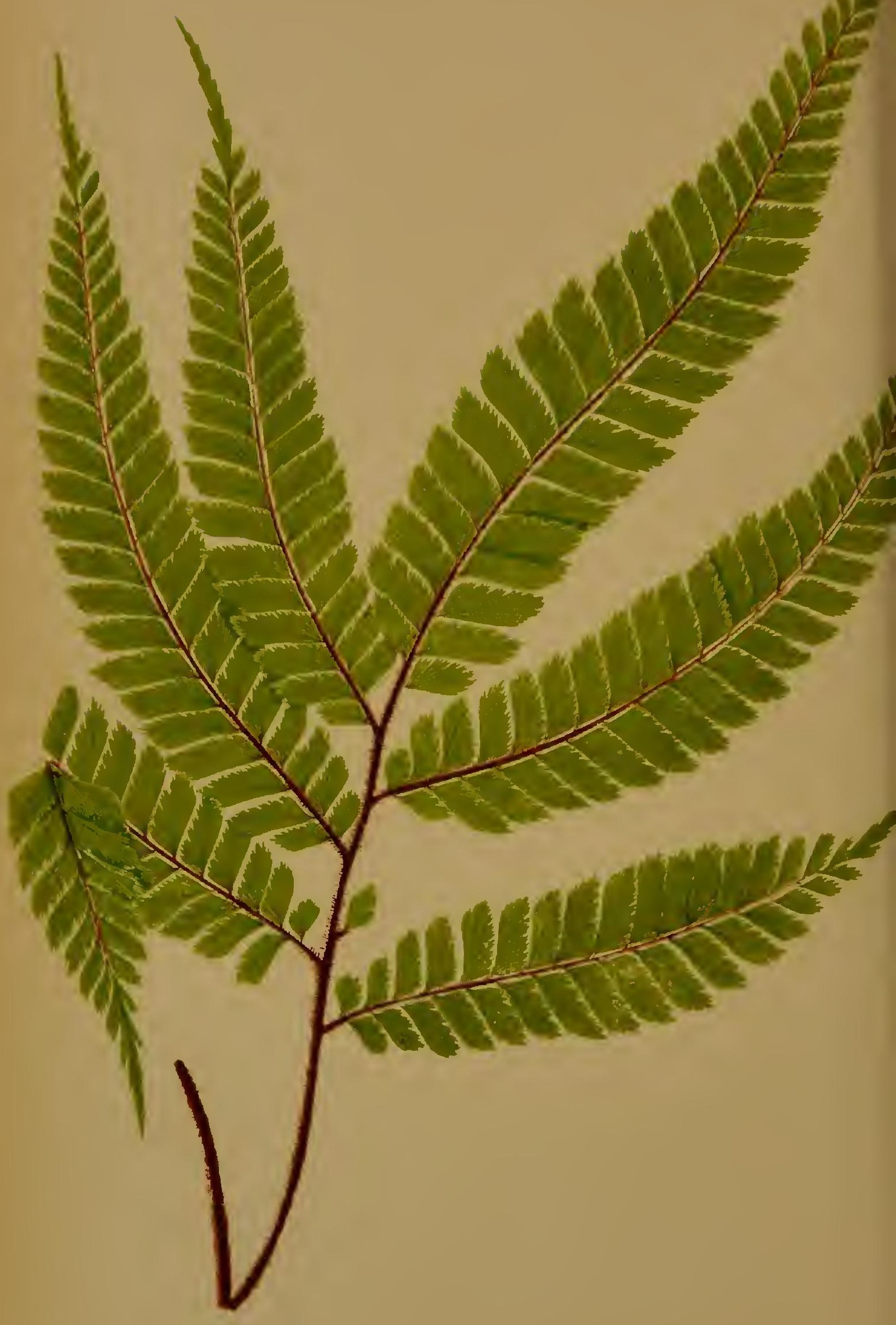


,

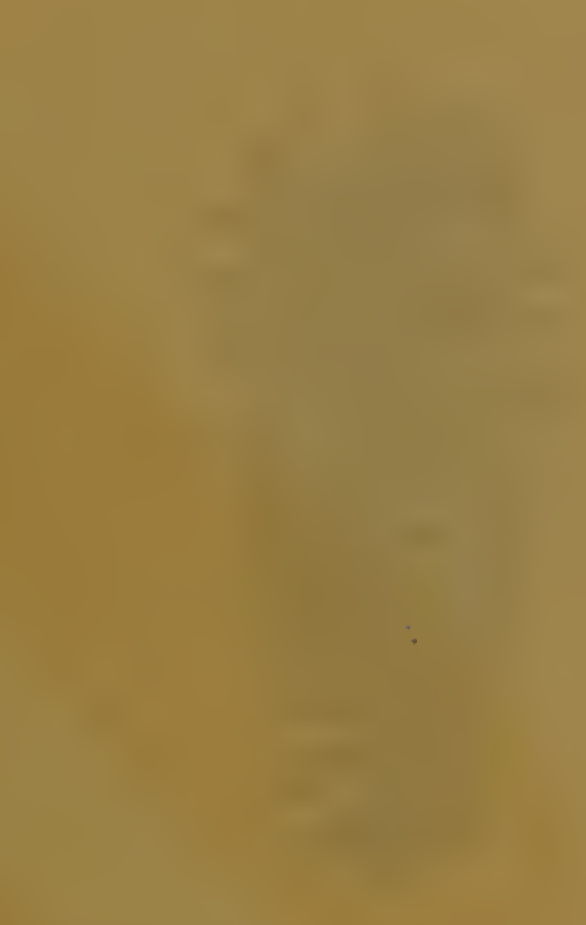

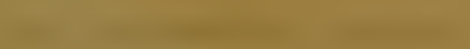

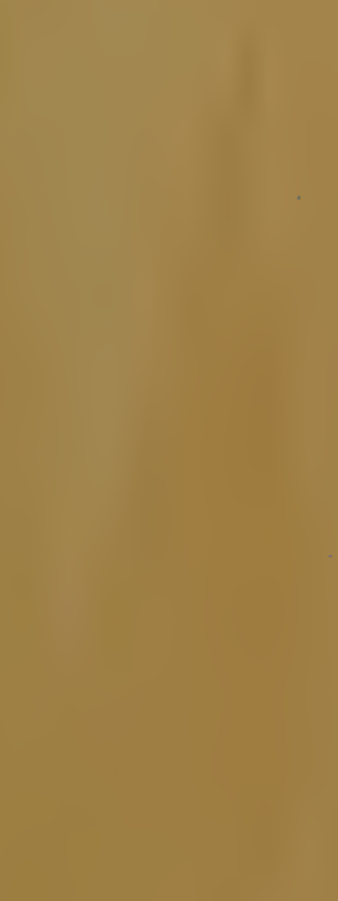

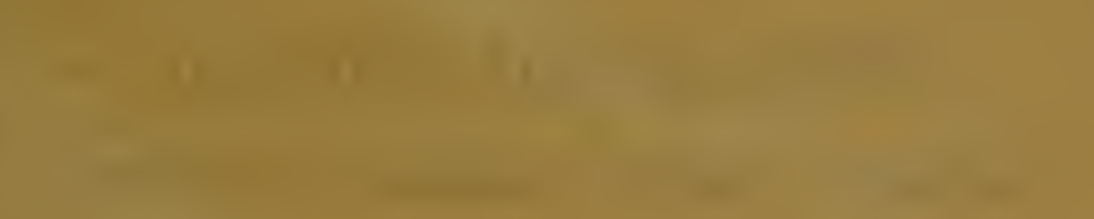

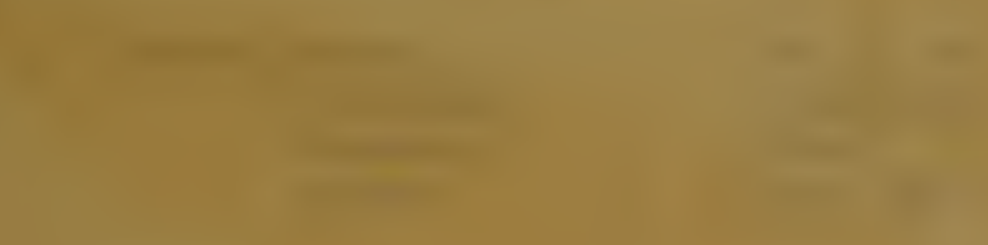

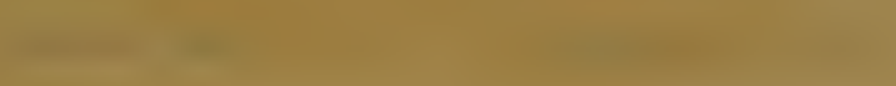

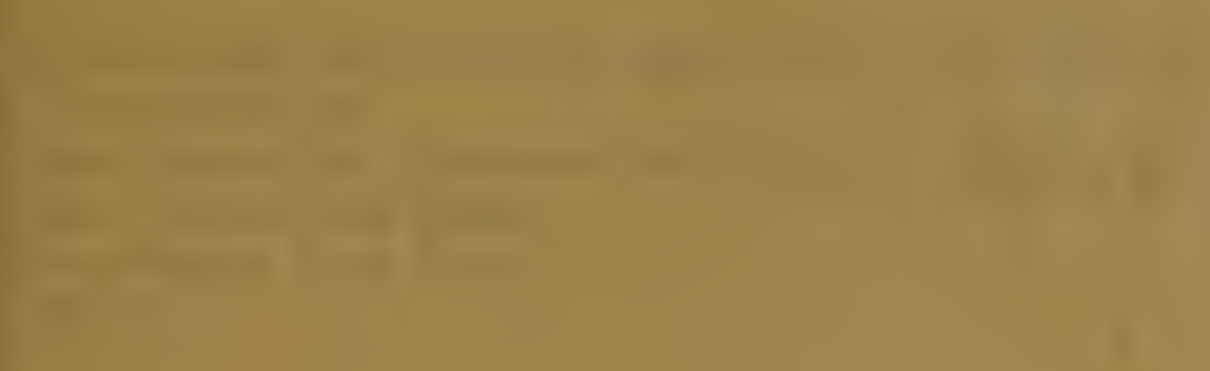



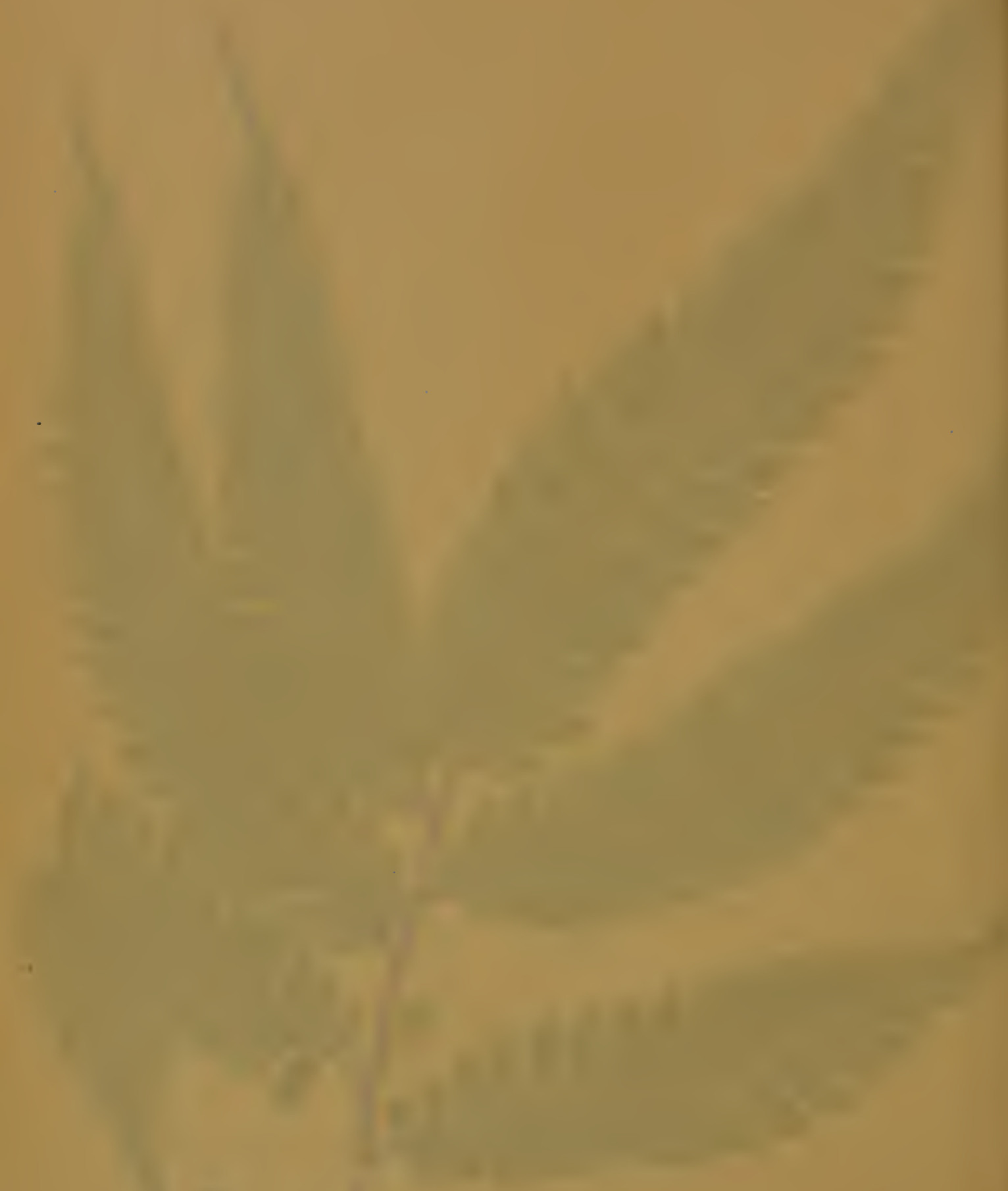

1

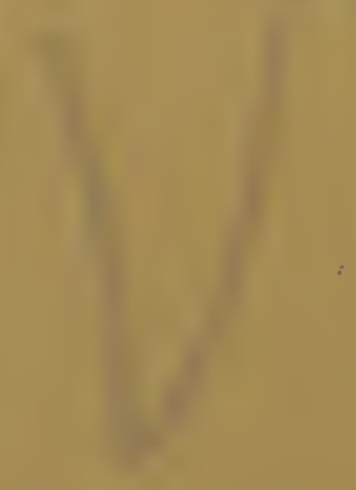




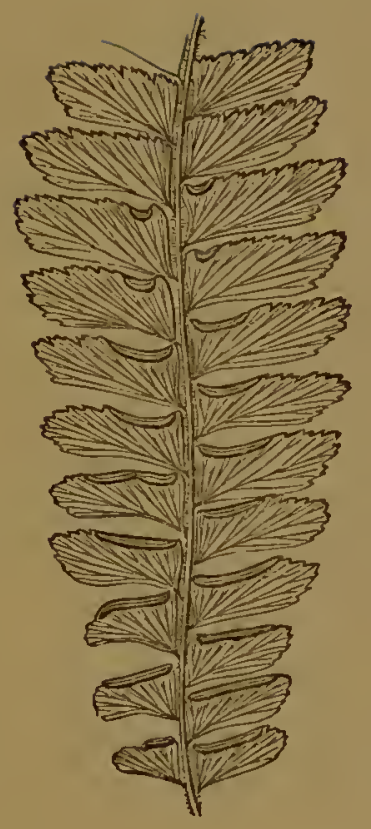

Portion of mature Frond-under side.

\section{ADIANTUM PULVERULENTUM.}

\section{Linnemus. Willdenow. Swartz. Plumier.}

PI,ATE XVII. VOL. III.

\section{Adiantum umbrosun, \\ " monosoratum, \\ " kunneanum, \\ " rigidum,}

Adiantum-Dry.
WILLDENOW.

Willdenow.

Prest.

SchotT M.S.

Ax interesting and uncommon species, only to be found in the larger collections.

It is a native of the Islands in the West Indies, Mexico, New Granada, Guiana, and Brazil.

An evergreen stove Fern.

VOL. III. 
Introduecd into England in the year 1793.

The fronds, which are bipinnatc and broadly ovate in form, have somewhat lanccolatc pinnæ, the pinnulcs being numcrous, closc together, and are gradually smaller in size as thcy approach the apex of the frond. Slightly petiolate, inore membranaccous than eoriaecous, oblong-dimidiatc, the upper base being parallel and elose to the rachis; the upper pinnules very small, and almost obovate.

Rachis and stipes covered with ferruginous hairs, so as to be quite rough.

Length of frond from twclve inches to two fcct; colour full grcen, and having a glossy appearance.

Sori linear and continuous, solitary, generally only occupying a portion of the superior margin.

Sir W. J. Hooker remarks that it is a more tender and mcmbranaecous plant than Adiantum villosum, with smaller, more copious, and mueh denscr pinnules, gradually tapering to a narrow point.

My thanks are due to Dr. J. D. Hookcr, of the Royal Gardens, Kcw, and to M. Sehott, of the Imperial Gardens of Sehonbrünn, near Vienna, for plants and fronds of this species.

I am not awarc that it is in any of the Nurserymen's Catalogues.

The illustration is from a plant in my own eollection. 

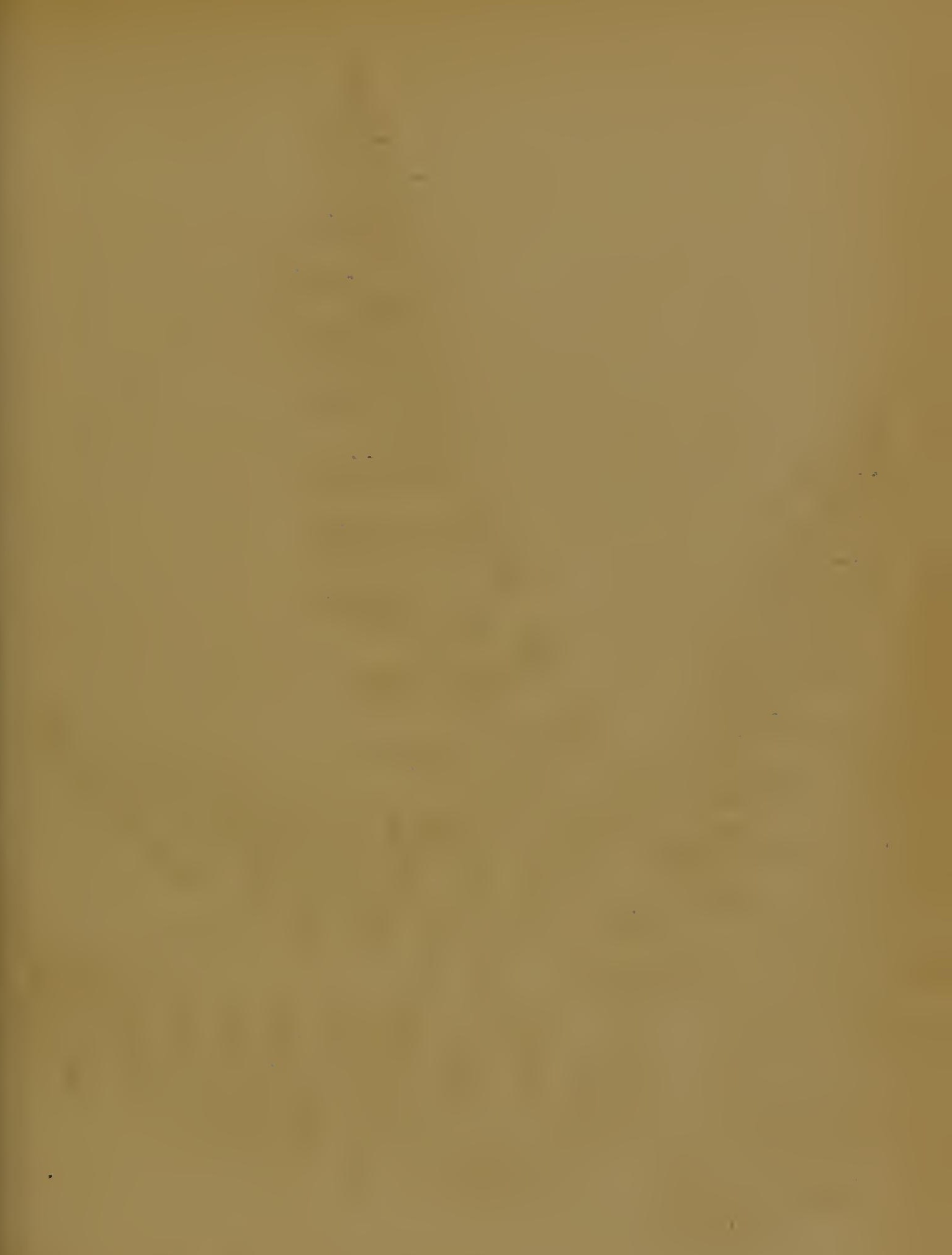

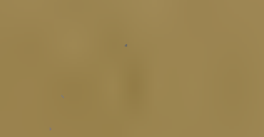
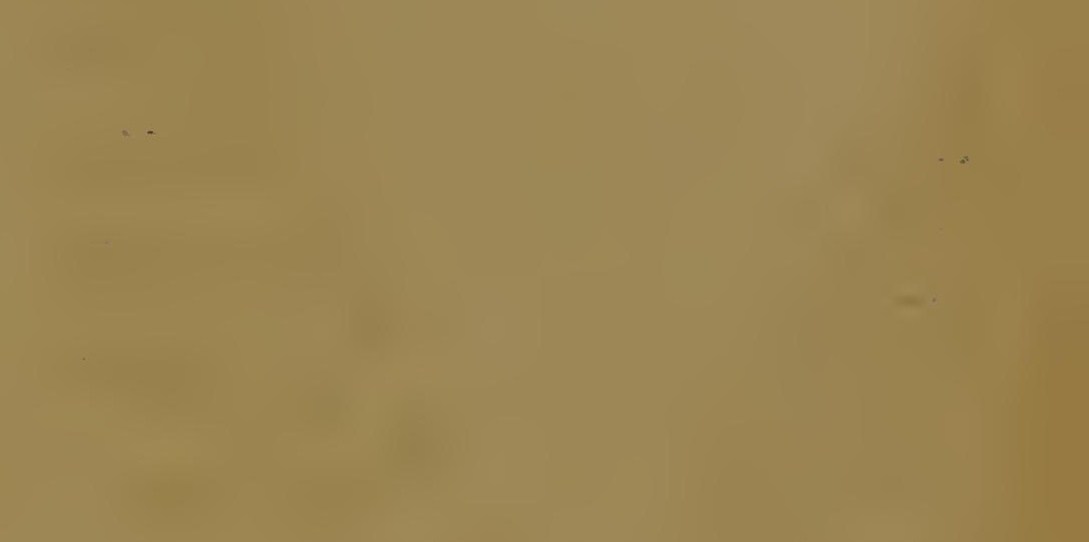

$y^{2}=-$ 


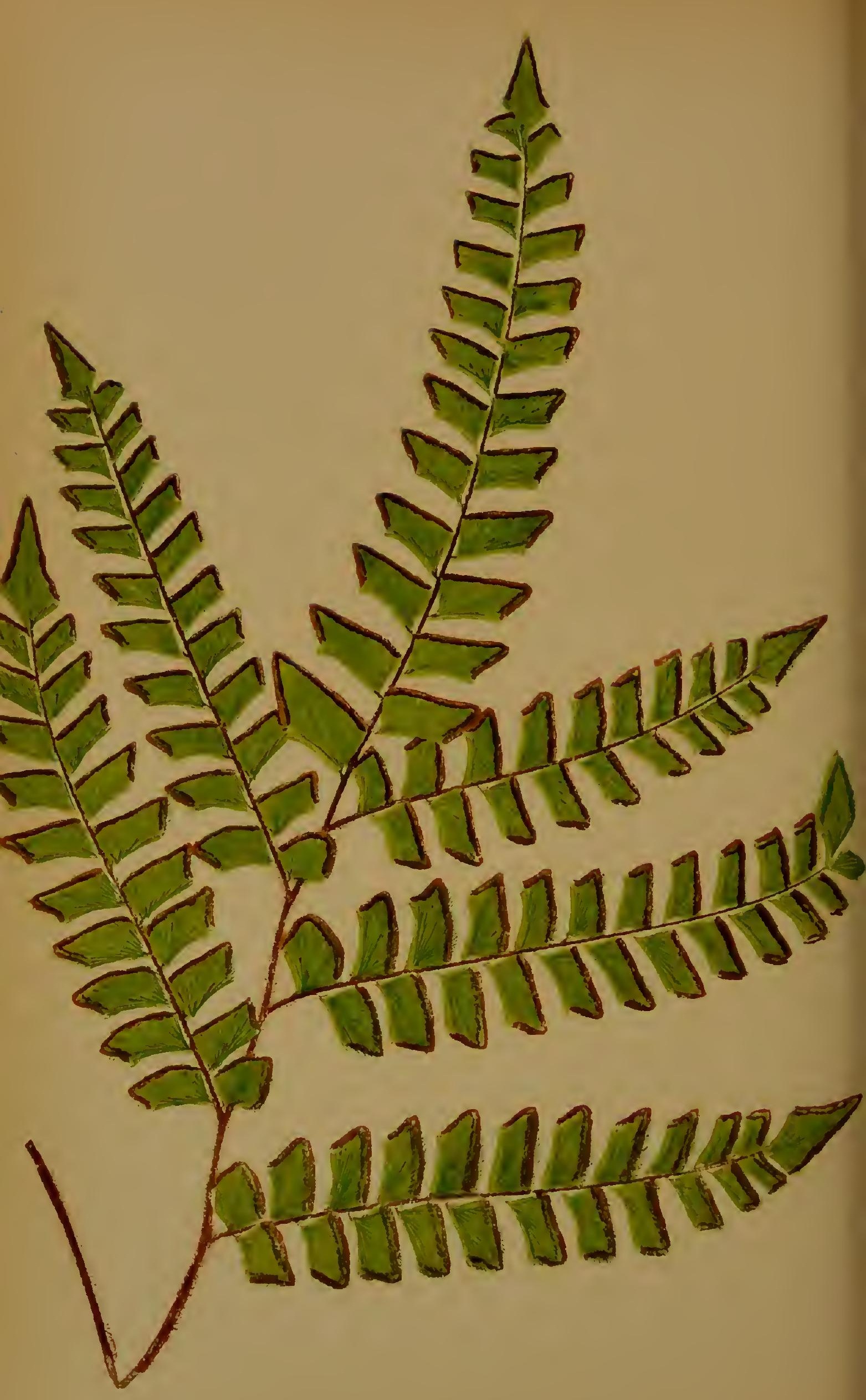




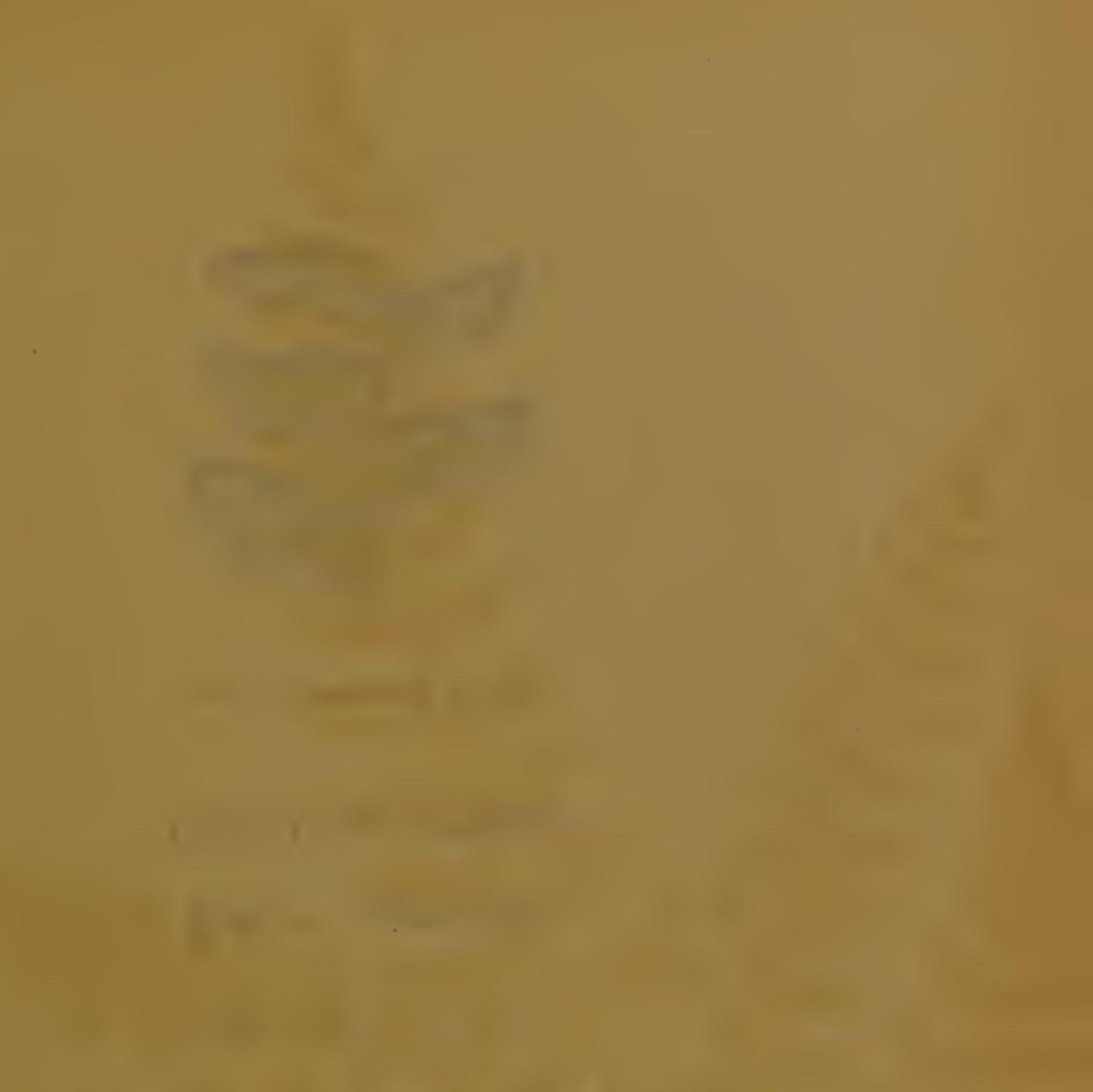

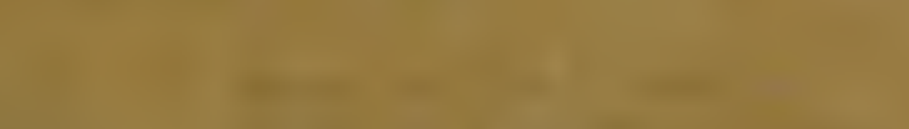
1.

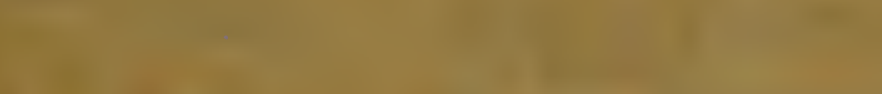
I.

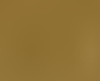
(6)

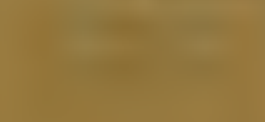

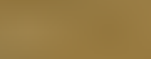

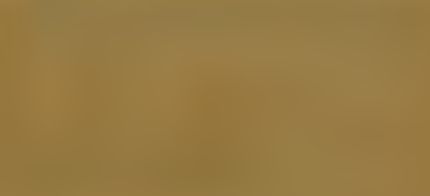

P

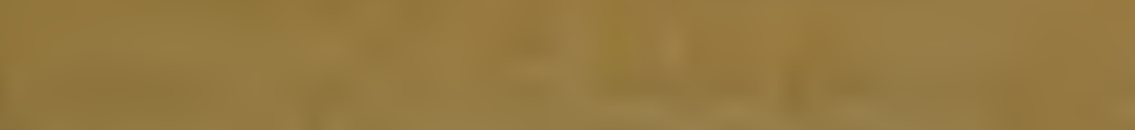

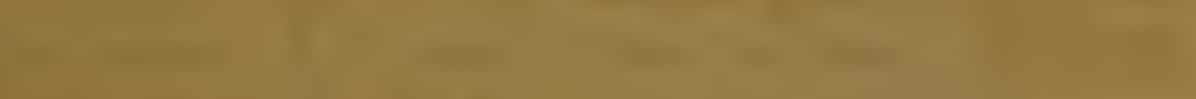

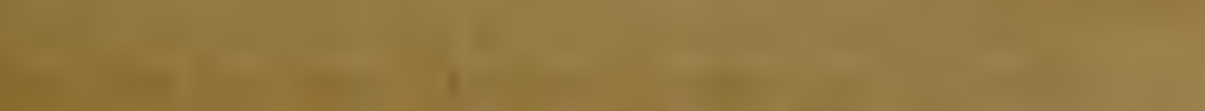

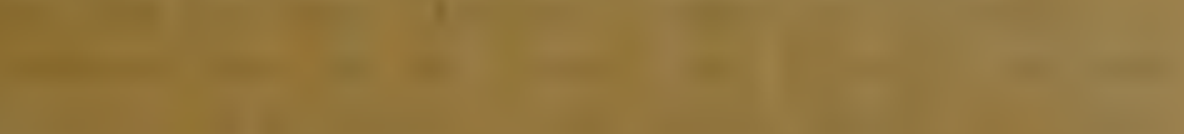

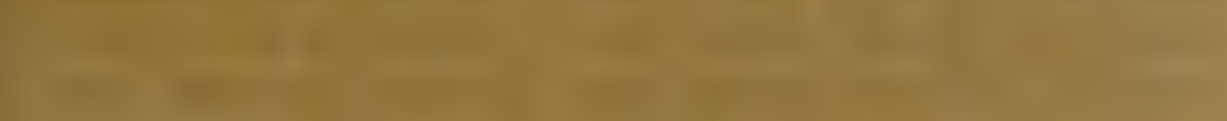




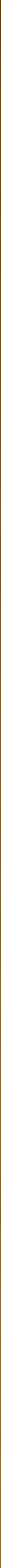




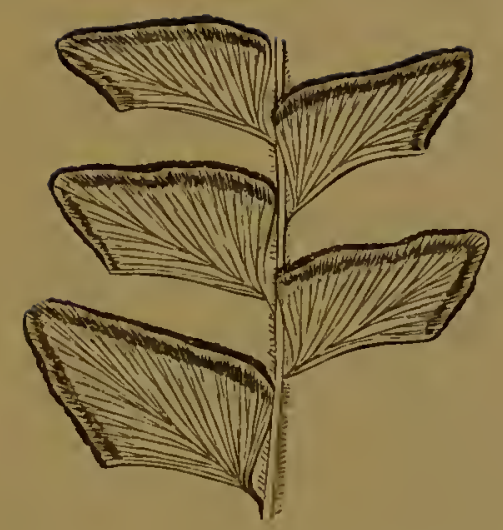

Portion of mature Frond-under side.

\section{ADIANTUM VARIUM.}

\section{HOOKER. WILLDENOW,}

PIATE XVIII. VOI. III.

$$
\text { Adiantum-Dry. Tariun-Various. }
$$

A Hannsome Fern, and one pretty well distributed in our English gardens. It is rather delicate, requiring care in its cultivation, and to be kept in a very warm atmosphere.

Some authorities place Adiantum varium and A. villosum as two different Ferns, yet they seem to run so closely into each other, that it is impossible to say which belongs to which; they have therefore been here considered as one and the same Fern, especially as Humboldt and Kunth have remarked, "an idem cum Adianto villoso." Sir W. J. Hooker, although he 
lias described both species, still, in the remarks regarding $A$. varium, speaks of the probability of its being the same Fern witl $A$. villosum.

An evergreen stove Fern.

Native of Venezuela, where it was found by Humboldt and Kunth.

Fronds pinnate and bipinnate, having pinnæ of a trapezoidoblong acuminate shape, sub-petiolate, glabrous, acutely serrated.

Rachis hirsute with filiform scales.

Length of frond twelve to cighteen inches.

Sori linear and continuous.

Introduced into England in the year 1820 .

For plants of this species I am indebted to Mr. Pass, gardener to Mr. Brocklchurst, of The Fence, near Macclesfield; Mr. Veitch, of Chelsea; and to Mr. A. Henderson, of Pine-apple Place: and for fronds to Dr. Hooker, of the Royal Gardens, Kew; Mr. J. Henderson, of Wentworth; Mr. Downes, of Hillsbro,' Ilfracombe; and to Mr. Norman, of Hull.

It is in the Catalogues of Messrs. A. Henderson, of Pineapple Place; Rollisson, of Tooting; Veitch, of Exeter; Parker, of Holloway; and Sim, of Foot's Cray.

The illustration is from a frond sent by Dr. Hooker. 


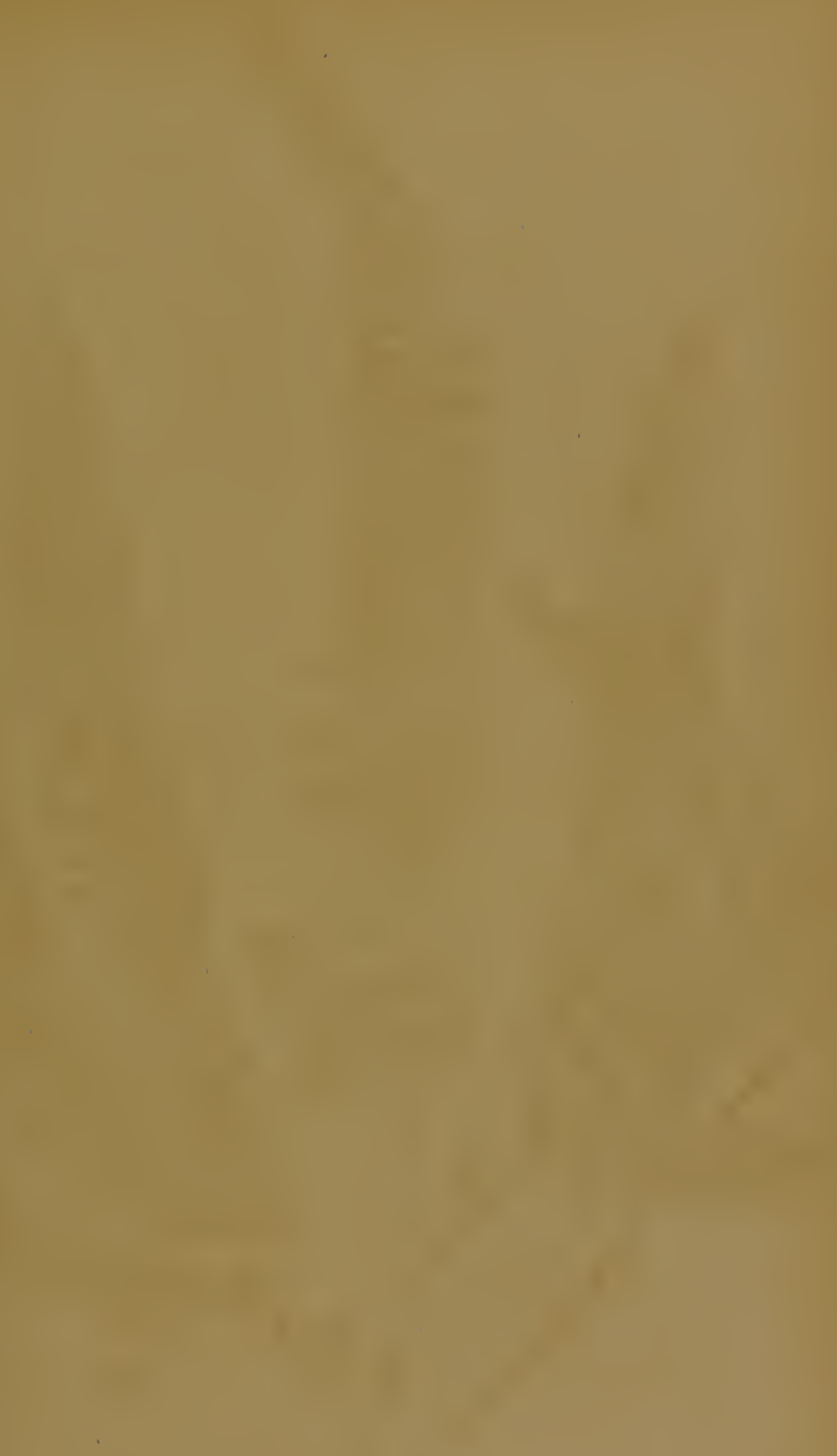




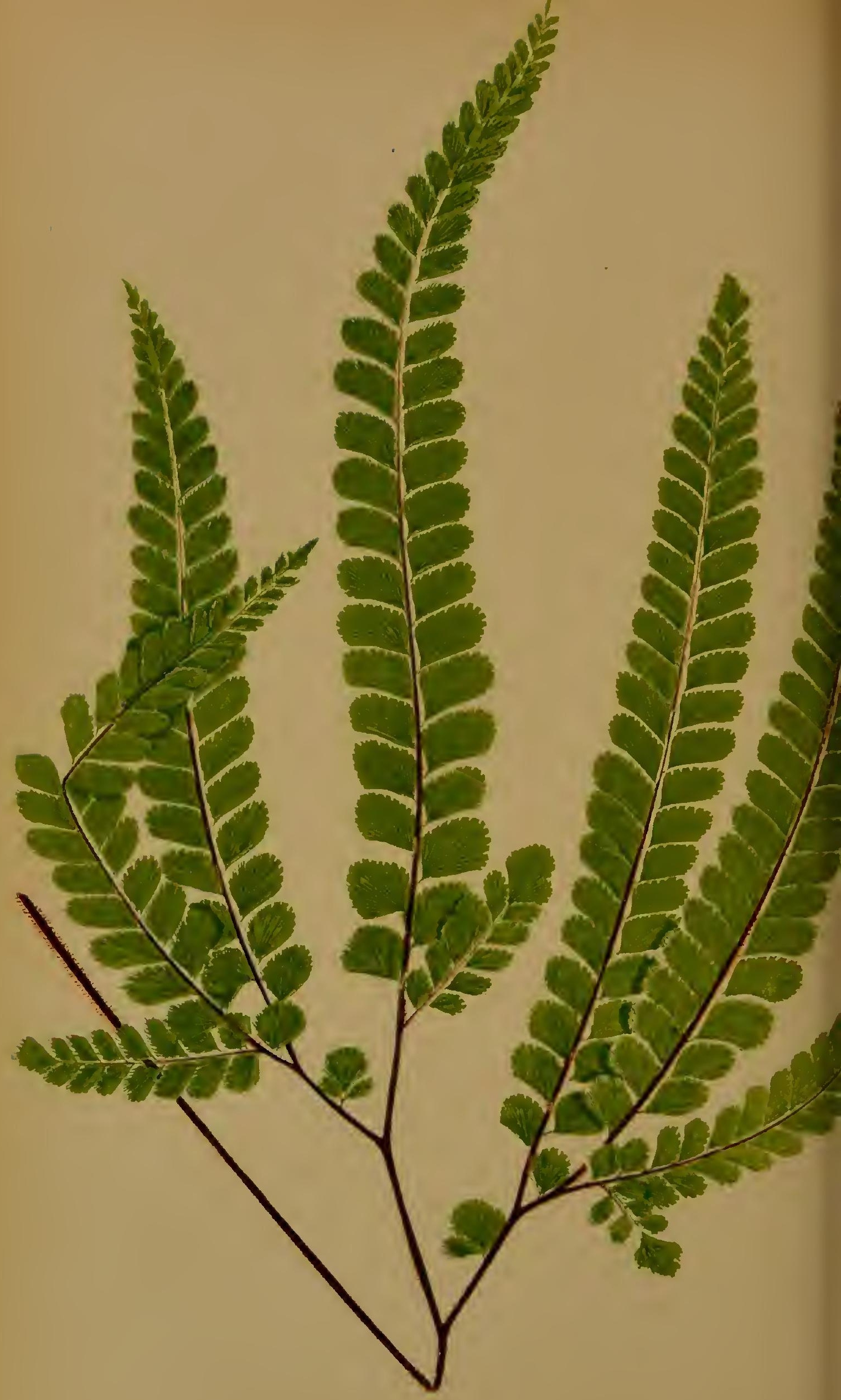





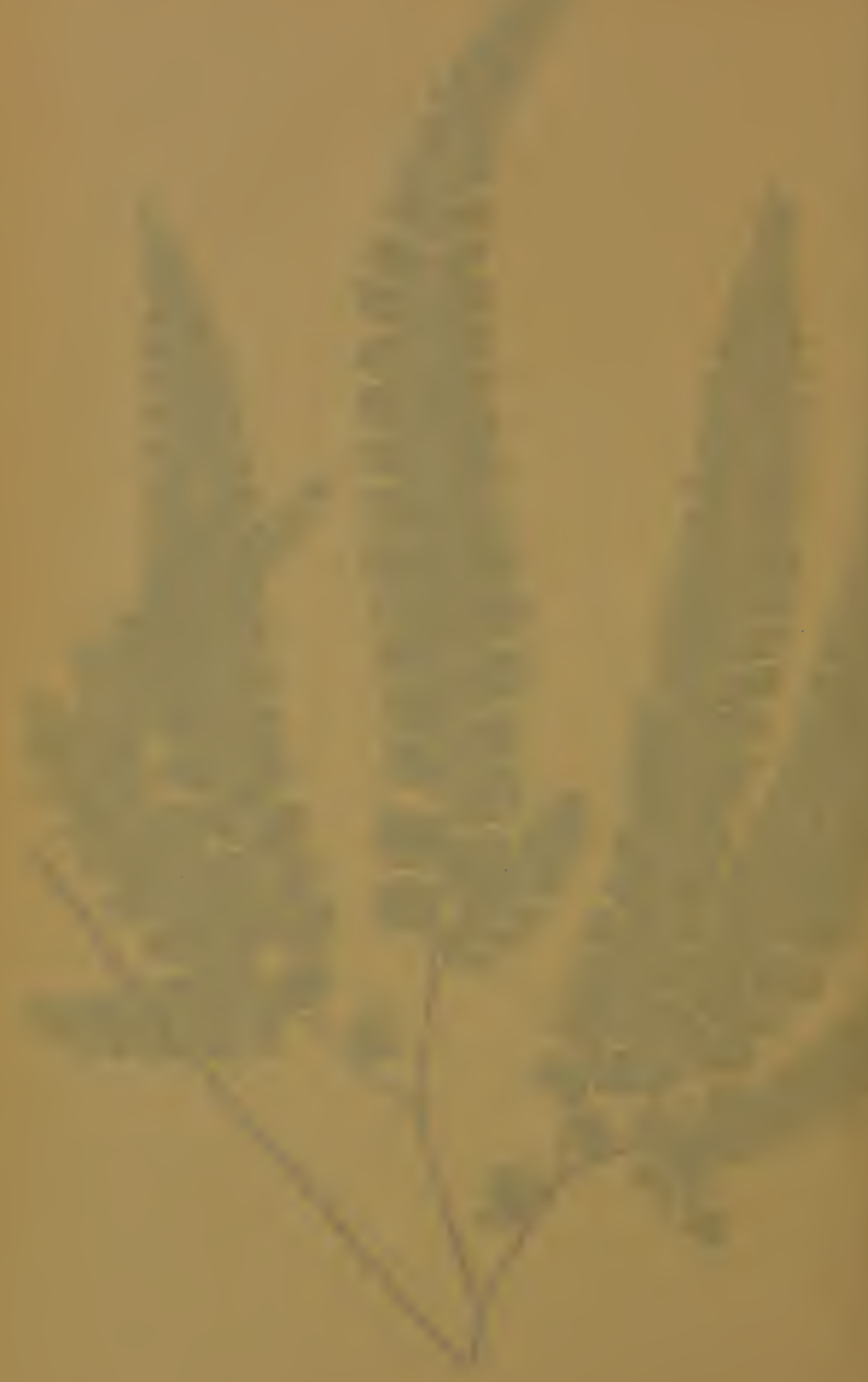




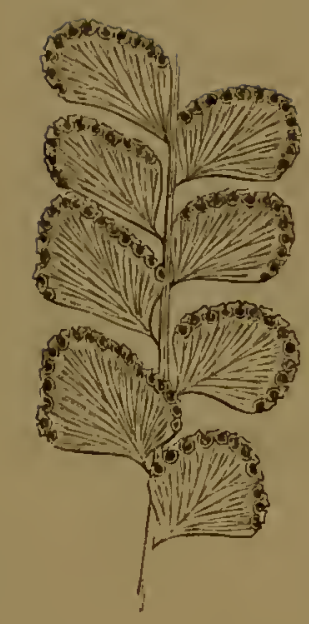

Portion of mature Frond-under side.

\section{ADIANTUM FULVUM.}

Raoli. Hooker. J. Smith. Fee.

PIATE XIX゙. VOL. III.

$$
\text { Adiuntum-Dry. } \quad \text { Fulvum-Tawny. }
$$

As interesting Fern, with sori very much resenbling the Adiantum cunninghami, whilst the plant itsclf is strikingly distinct. Most probably it is very rare in England, as I am not aware that it is in cultivation anywhere cxecpt at Kew.

An evergrecn grecnhouse Fern.

A native of New Zealand, where it has becn found growing abundantly by Dr. Sinclair, Dr. J. D. Hooker, Mr. Raoul, and Ir. Colchiso.

The fronds are ovate-deltoid, sub-pedately, triquadripinnate, the sccondary pinna being of a lanceolate-acuminate form; pinnules small, chartaccous, sub-glossy, gliabrous, dimidiatooblong-obtuse, obliquely wedge-shaped at the base, broadly cultrifrom, superior base truncate, superior margin and obtuse

YOL. JII. 
apex lobed, the lobes being emarginate, obtuse, sinuses of the lobes soriferous; sori large and numerous, from eight to twelve on a pinnule, involueres orbicular-cordate, the sinus decp and narrow. Stipes very seabrous; rachis scabrous and downy, with fulvous hairs.

Length of frond twelve inches; colour bright olive green.

My thanks are due to Mr. J. Simith, the Curator at the Royal Gardens, Kew, for fronds of this species.

It is not in any of the Nurserymen's Catalogues.

The illustration is from a plant grown in the Kew Gardens, and forwarded by Mr. Smith. 

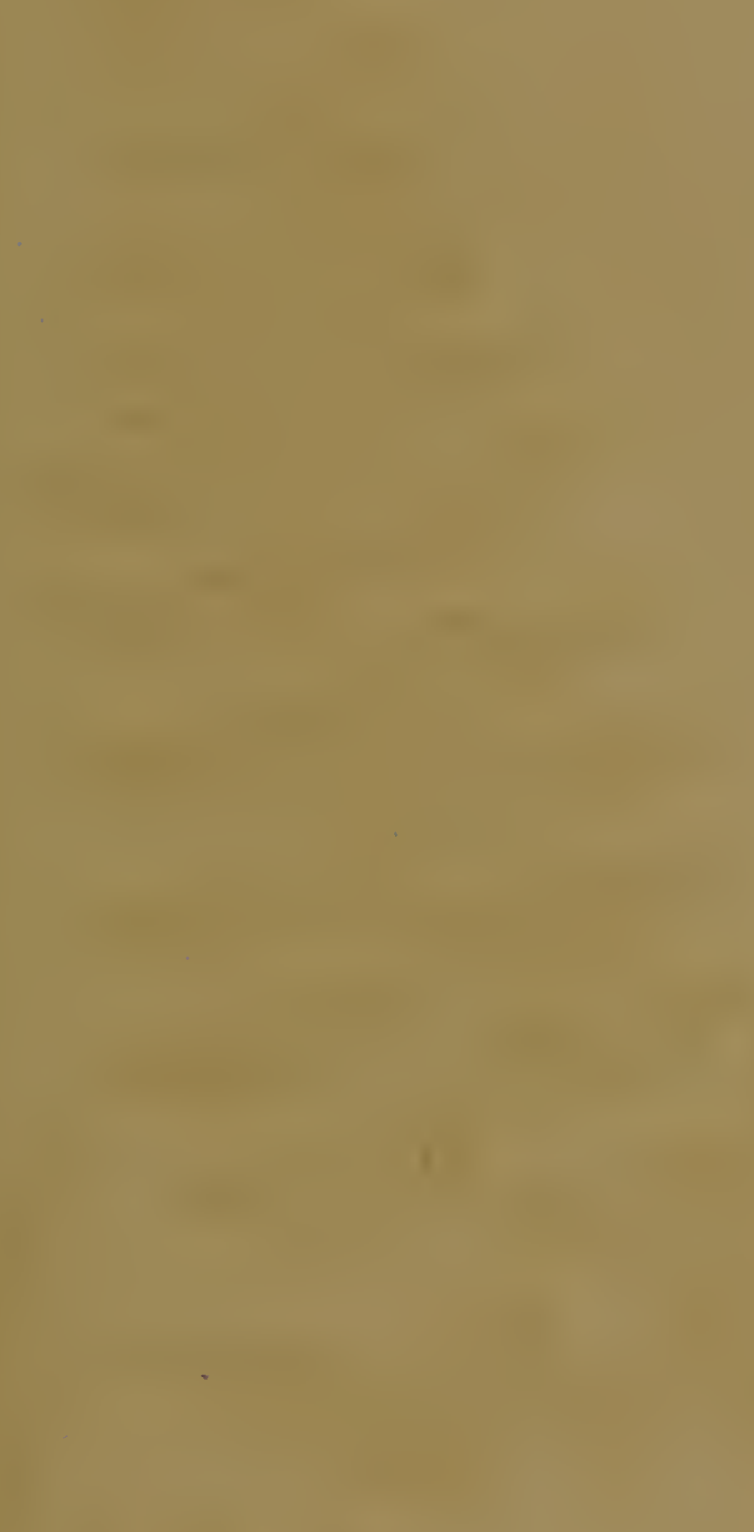


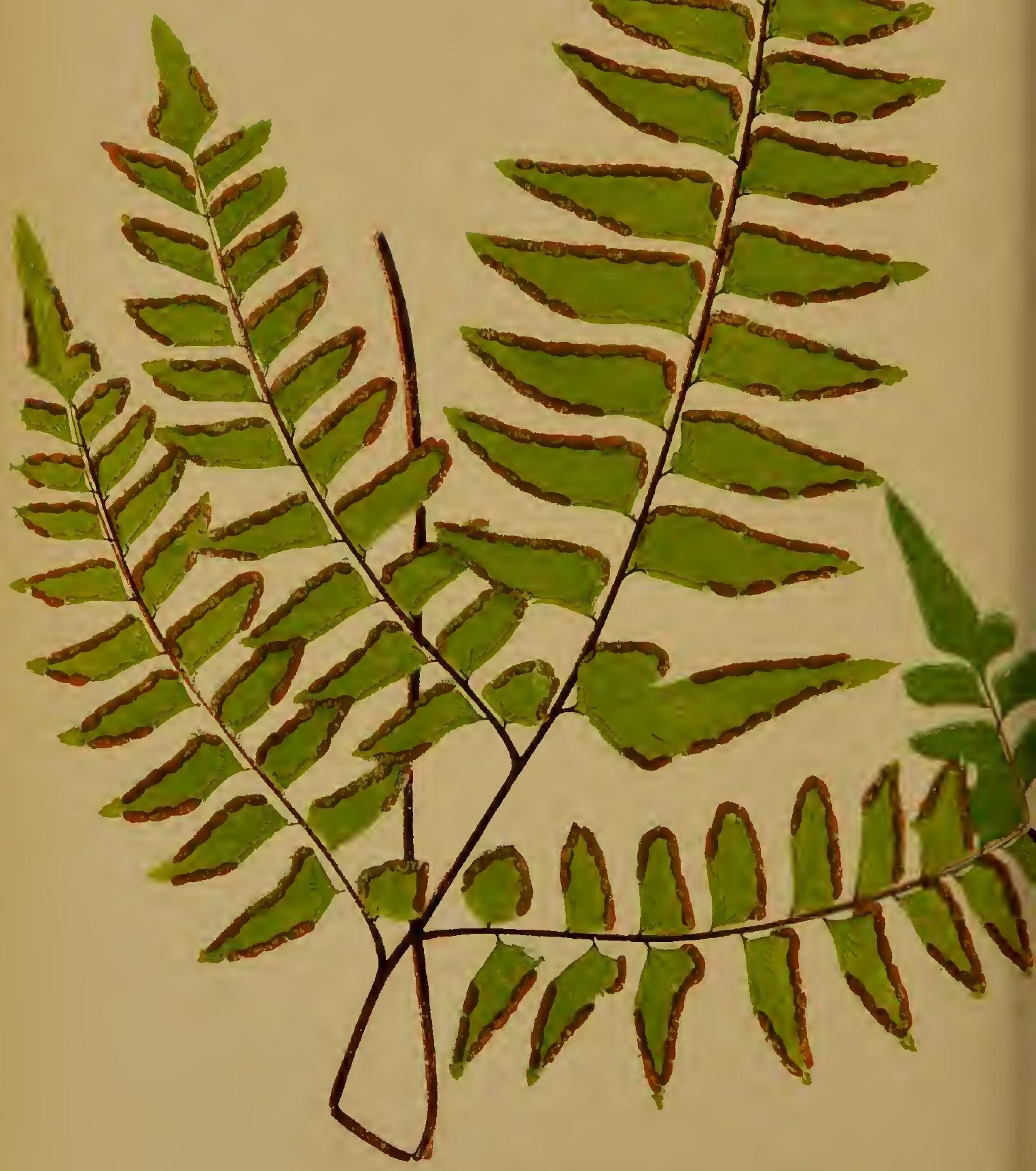



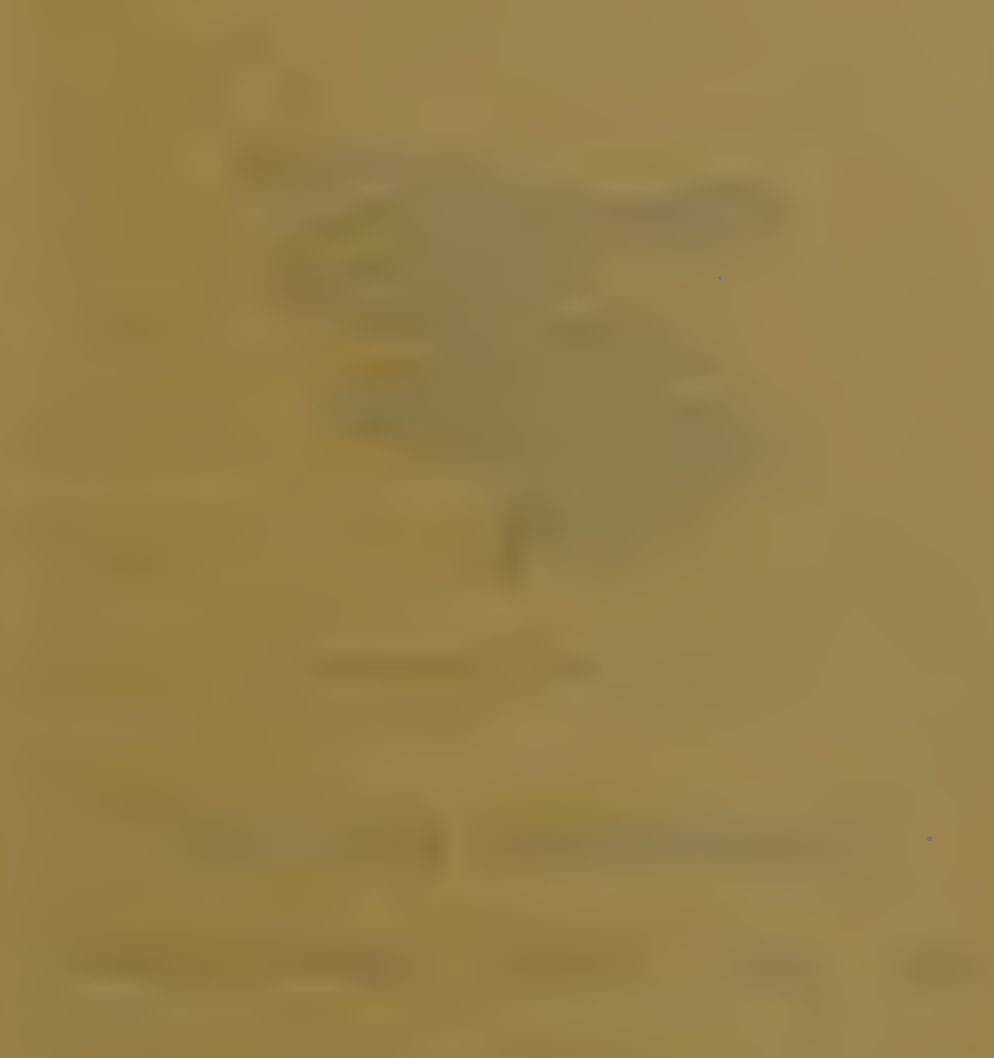

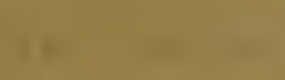

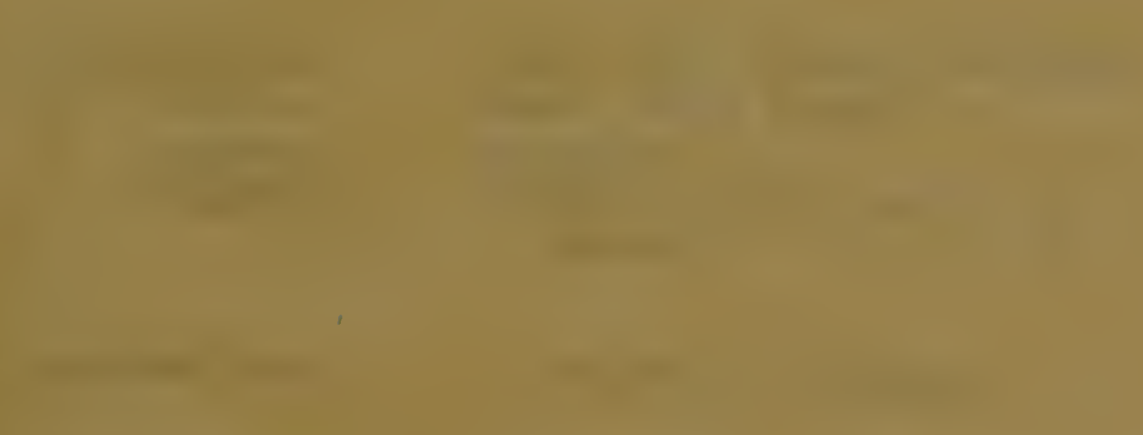

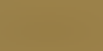

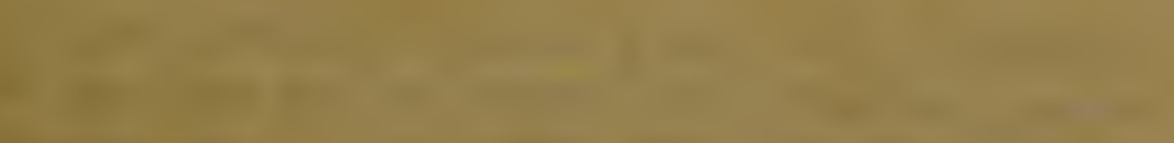

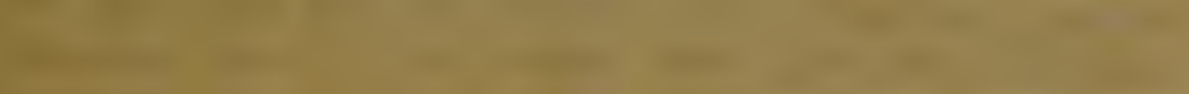

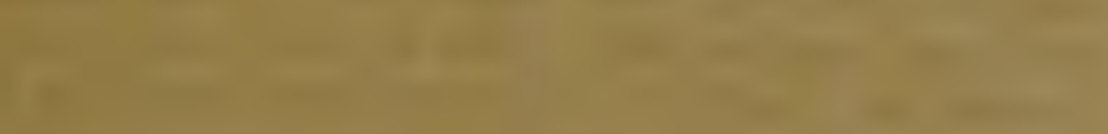

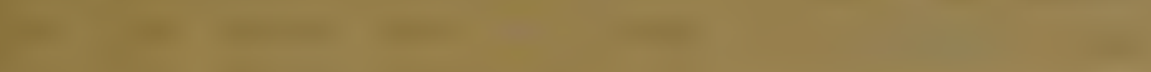
.

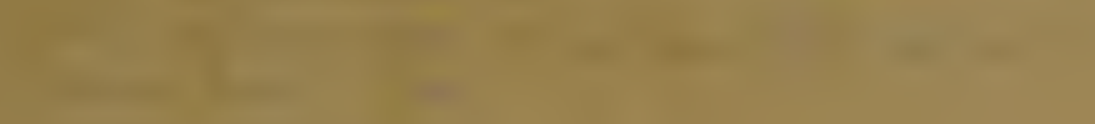



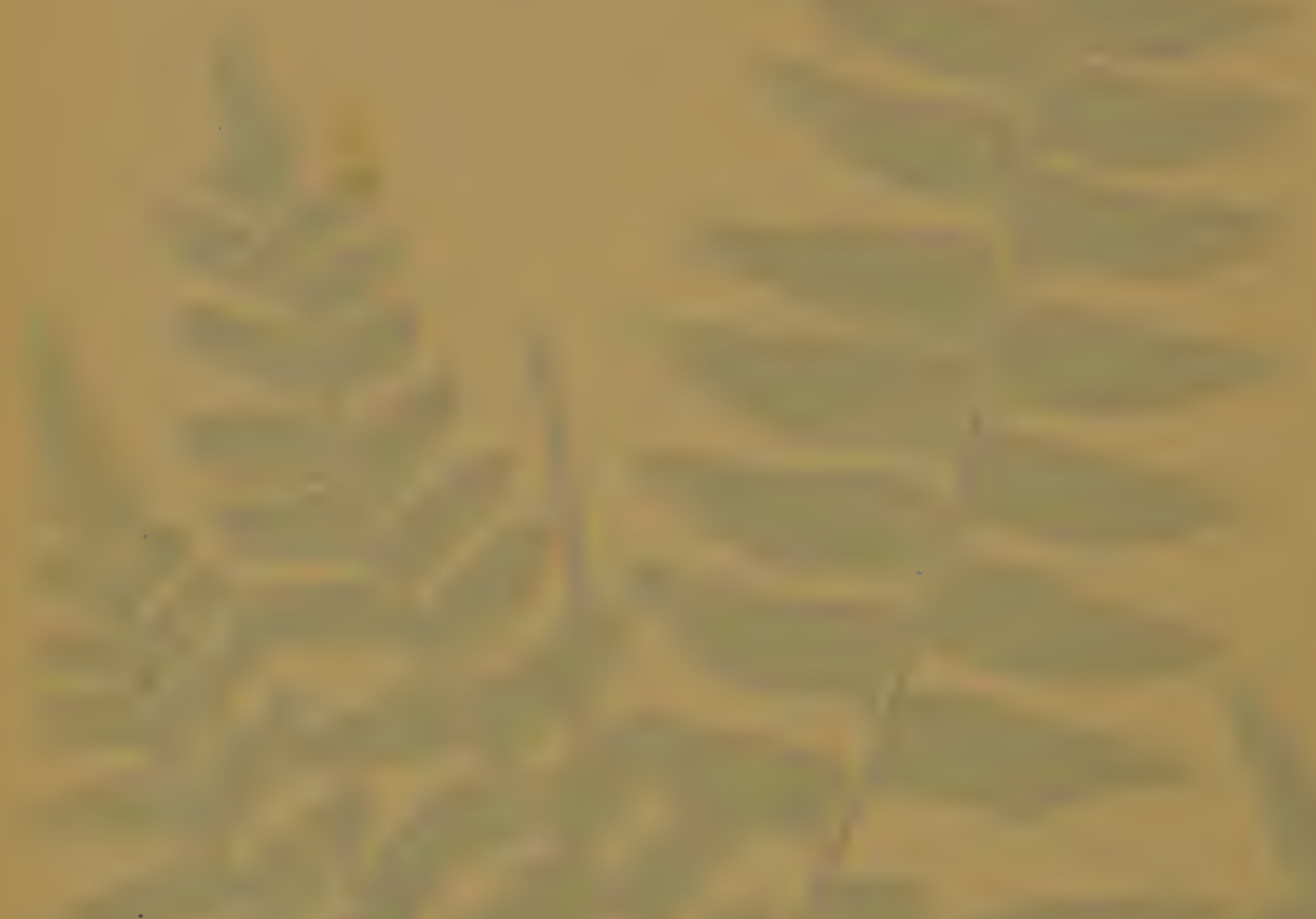

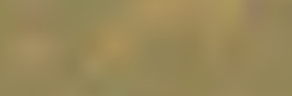

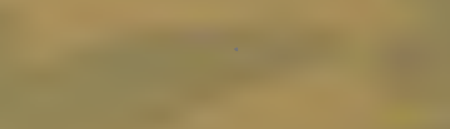

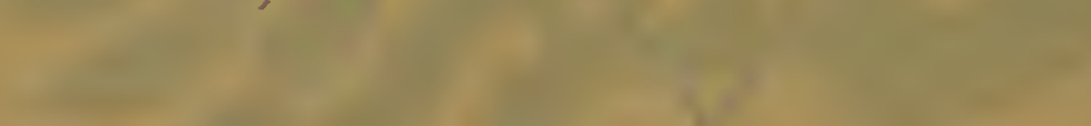

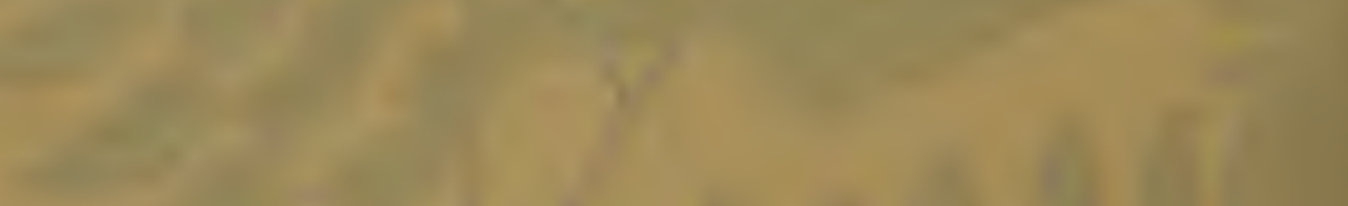

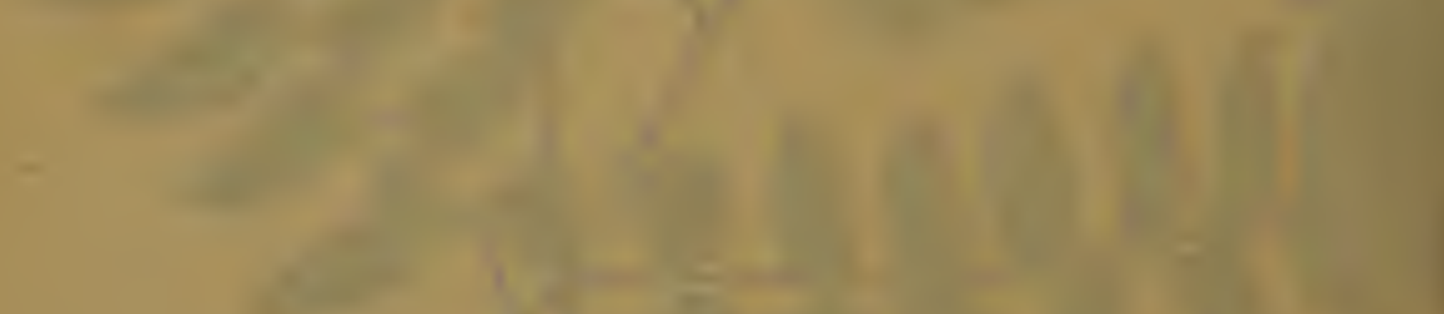

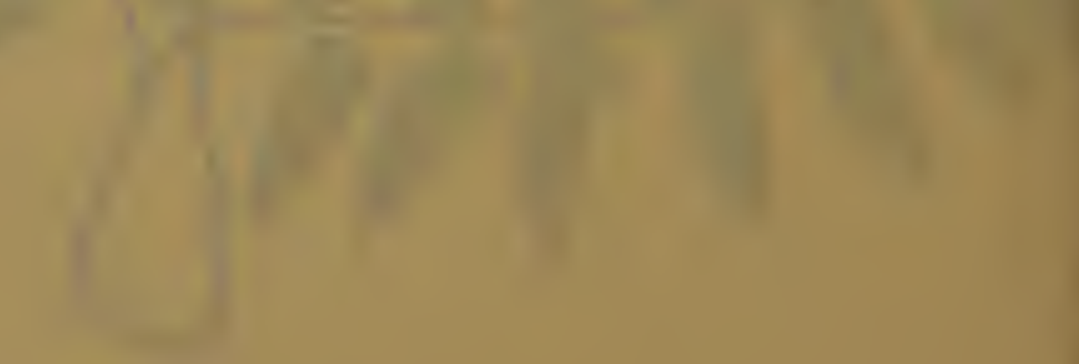




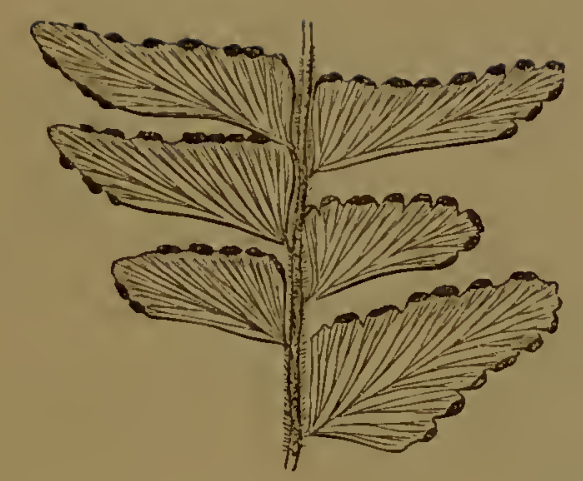

Portion of mature Frond-upper side.

\section{ADIANTUM INTERMEDIUM.}

Swartz. Hooker. Presl. Kunze. Fee.

PLATE XX. VOL. III.

Adiantum fovearum,
" brasiliense,
" $\quad$ argutum,
triangulatum,

Adiantum-Dry.
Raddi. Link. Moore \& Houlston.

LINK. (Not of RADDI.)

SFLITZGERB.

MoricaUd. (Not of KaUlfuss or Hooker.)

A Haxisone Adiantum, deserving a place in every collection, its bold prominent sori and hirsute stems render this speeies an interesting Fern. It is perhaps more generally eultivated than growers are aware of, being sometimes scen under the name of cristatum, oeeasionally that of varium and villosum, although these species are very distinct from Adiantum intermedium by having continuous sori.

Introdueed into this country in the year 18.44, and into the hoyal Gardens, Kew, in 1840.

An crergreen stove specics. 
A native of tropieal America,-Brazil, Ilhios, Guiana, Amazon, New Grenada, Mexico, Guayaquil, Peru, West Inclian Islands, Jamaica, 'Lrinidad, Dominica, and Guadaloupe.

The fronds are lipinnate, pinne oblong-acuminate, from five to seven lateral ones, horizontal, the terminal one being elongated; pinnules ovatc-oblong, obtuscly acuminate, wedge-shaped at the base, the upper base being parallel with the rachis. Sterile pinnules obseurely lobate, serrate. 'The fertile pimules have a scrrated apex.

Stipes angular, ebeneous, rachis ferruginco-hirsute, attached to a crecping clongate caudex.

Sori large, oblong, numerous.

Length of frond from one to two feet; colour decp grecn.

'There are several Forns very nearly allied to this: $-A$. prionophyllum, Hooker; A. fructuosum, Hooker; A. triangulatum, Kaulfuss.

My thanks are duc to Messrs. Rollisson, of 'Tooting, for a plant of this Fcrn; and to Messrs. Henderson, of Wentworth; Mrs. Riby, of Papplewick; Messrs. Booth, of Hamburg; Messrs. Stansficld and Son, Vale Gardens, Todmorden; and Mr. Norman, of Hull, for fronds.

It is in the Fcrn Catalogues of Messrs. Booth, of Hamburg; Mastcrs, of Canterbury; Rollisson, of Tooting; Veitch, Jun., of Chelsea; Stansficld, of Todmorden; and Parker, of Holloway.

The illustration is from a frond given to me by Mr. J. Smith, the able Curator of the Royal Cardens, Kow. 



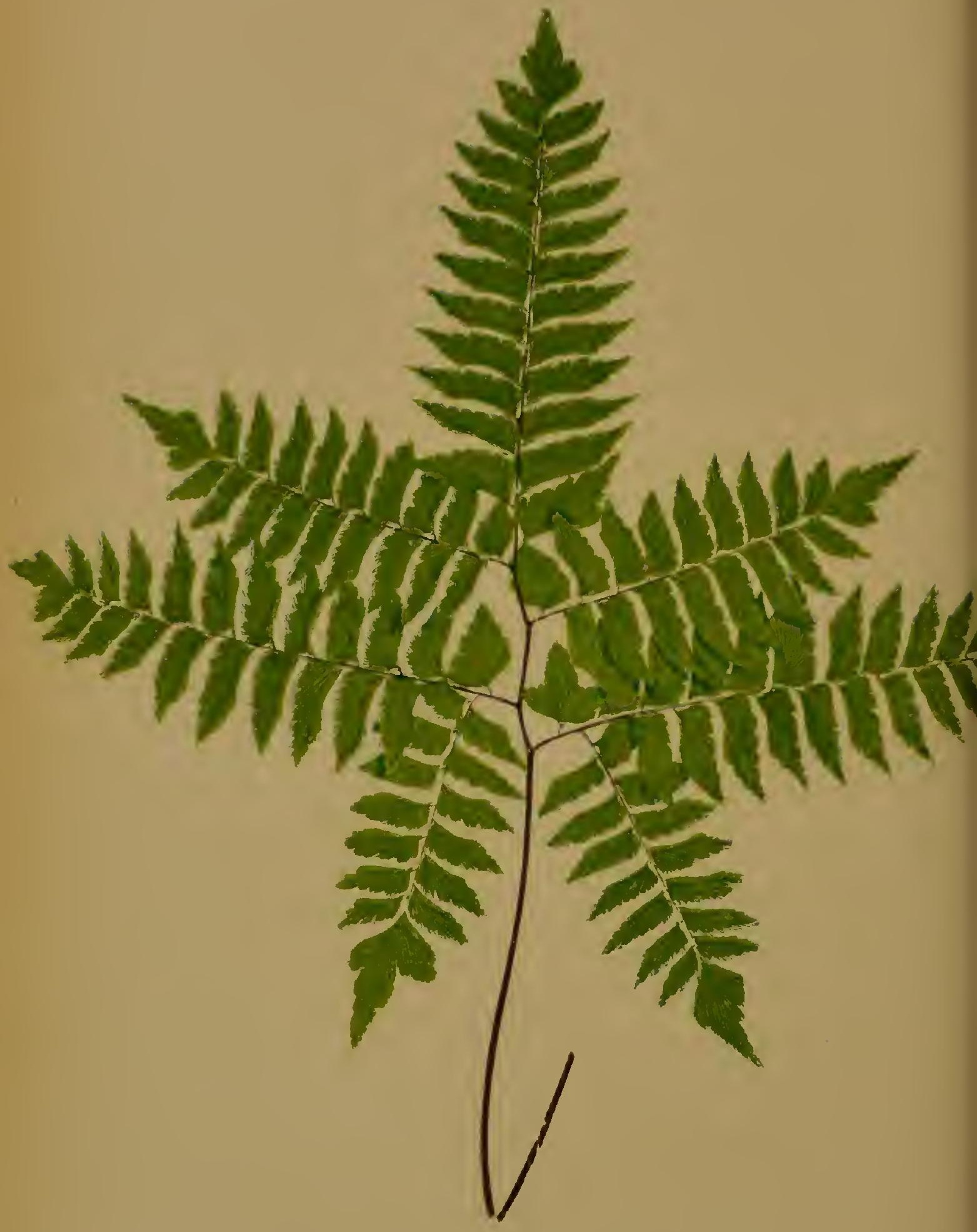


1
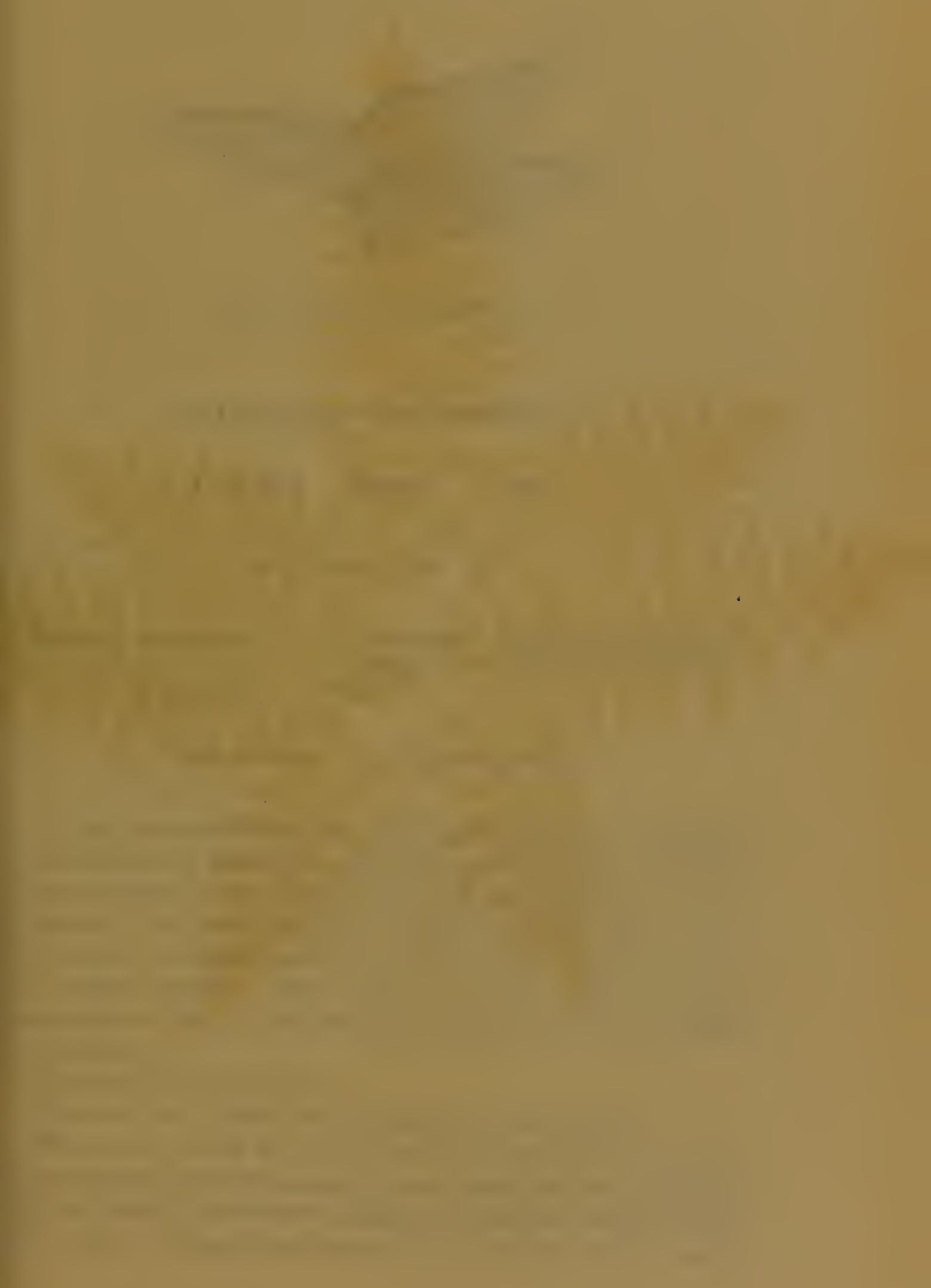


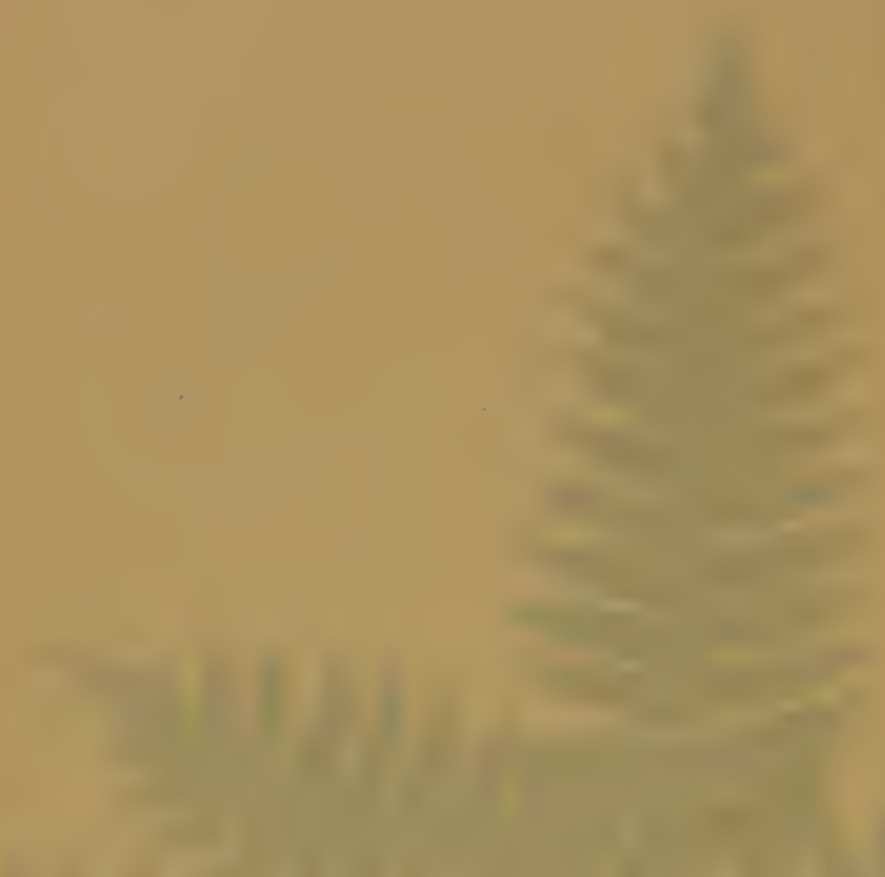

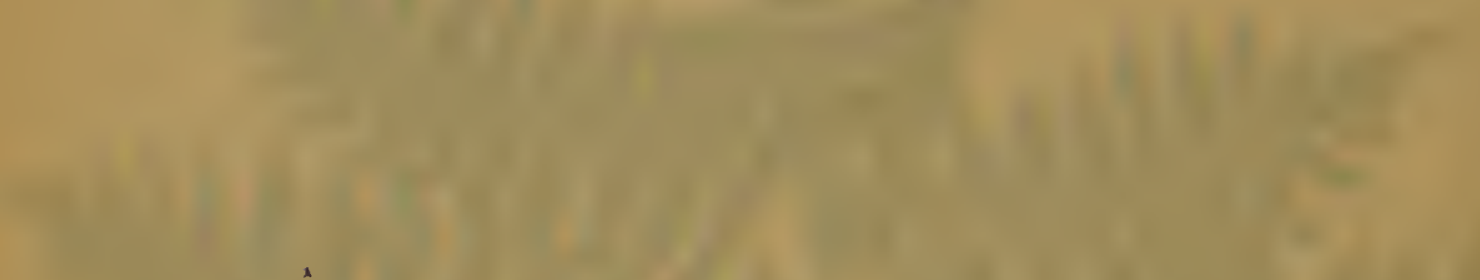

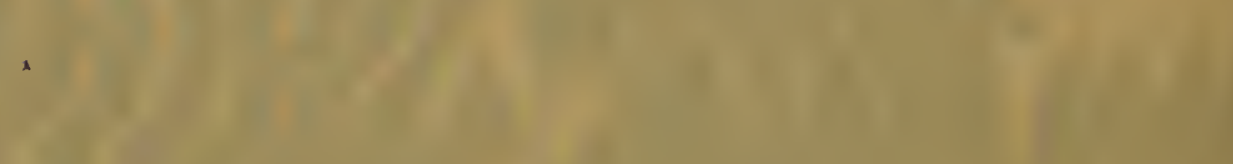

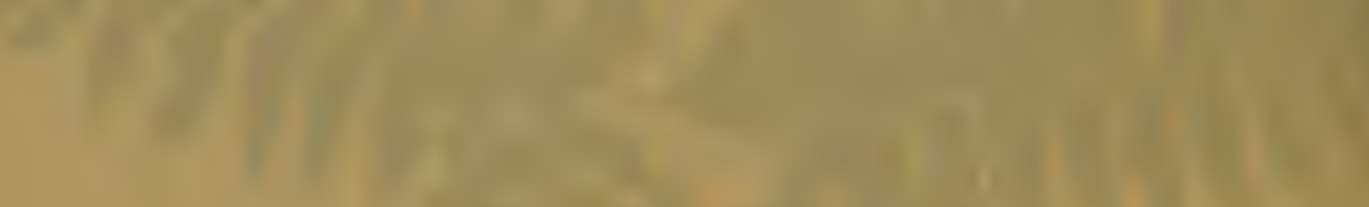

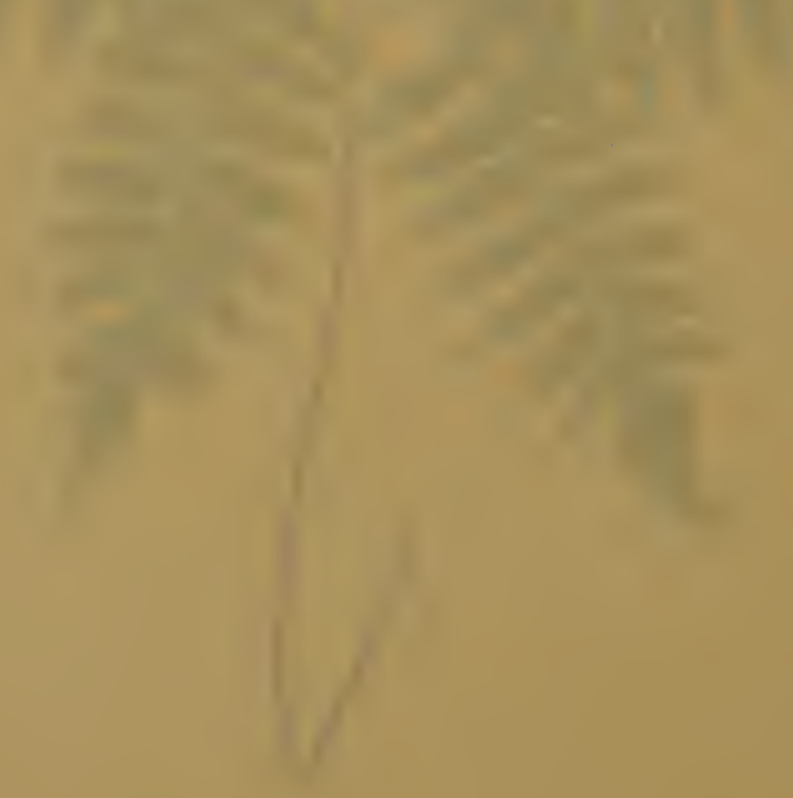




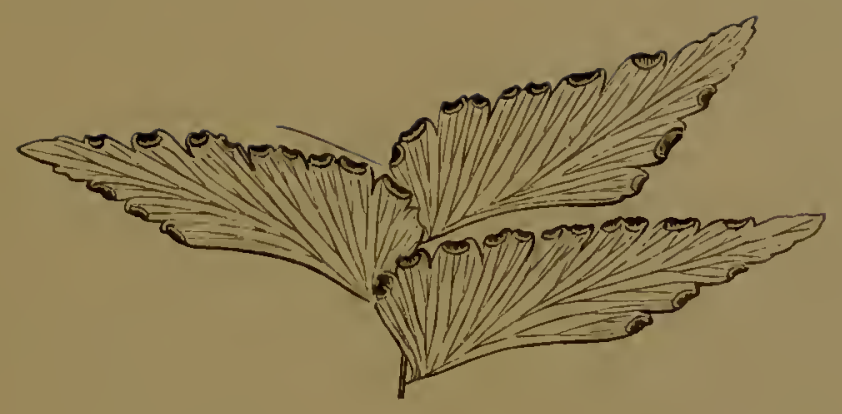

Portion of mature Frond-under side.

ADIANTUM CULTRATUM.

J. Simth. Hooker. Presl.

PLATE XXI. VOL. III.

\begin{abstract}
Adiantum pentodactylon, OF Gardens. (Not of LavgsdorfF anj Fischer, nor of Hooker \& Greville.

“ trapeziforme, FEE.
\end{abstract}

Adiantum-Dry. Cultratum-Sharp.

A VERY handsome Fern, in the same section with Adiuntum trapeziforme, yet scemingly very distinet, not only in the form of the pinnules, but in the colour of the indusium; in trapeziforme it is black, whilst in cultratum it is searlet. The Fern found in gardens under the name of $A$. pentadactylon, is the present species. When plenty of room is given it, this species grows into a handsome plant, and is not at all difficult to cultivate.

An cvergreen stove Fern.

Native of St. Vincent, St. Catharinc's, and Brazil.

'The fronds, which are large, are decompound; the pinnules being chartacco-mcmbranaceous, approximatc, pctiolate, spreading, narrow, oblong, approximate, obliquely rhomboid, obtusely lobed, and subincised, upper base truncate, and parallel with the rachis, 
lower base elongated and curved; lobes soriferous; involucres oblong-reniform, and scarlet. Stipes, rachis, and pediccls ebencous and black.

Length of frond two fect; colour pale grecn.

My thanks are duc to Messrs. Veitch, Jun., of Chelsca, and Messrs. Rollisson, of Tooting, for plants of this spccies; and to Mr. Henderson, of Wentworth; Dr. Hookcr, of $\mathrm{Kcw}$; Mr. Smith, of Kew; Mr. T. Moorc, of the Chelsea Botanic Gardens; Mr. Sim, of Foot's Cray; and Mr. Norman, of Hull, for fronds. It is in the Fern Catalogues of Messrs. Veitch, Jun., of Chclsea; Rollisson, of Tooting; Hendcrson, of Pinc-apple Placc; Parkcr, of Holloway; Sim, of Foot's Cray; and Cooling, of Derby.

The illustration is from a plant in my own collection. 
ron 





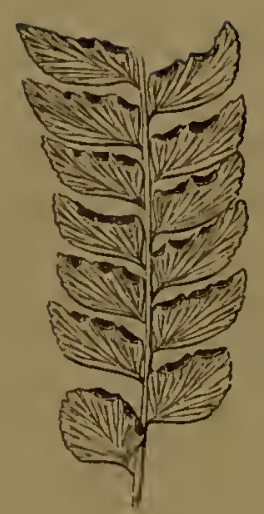

Portion of mature Frond-under side.

\section{ADIANTUM CRISTATUM.}

\section{Linnaus. Wilidenow. Swartz. Hooker. J. Shith. Presl. Kunze. Kaulfuss. Fee.}

PLATE XXII. VOL. III.

Adiantum striatum,

SWartz. JacQuin. Plumier. Kunze.

Adiantum-Dry.

Cristatum-Crested.

A undNDSOME yet imperfectly known stiff-growing specics, indecd in cultivation the name means almost any thing-varium, villosum, serrulatum, denticulatum, intermctium, ctc., are each to be met with under the name of cristatum.

An cvergreen stove Fern.

Native of Jamaica, Cuba, and Caraccas, bcing a most abundant Fern in the first-mentioned island.

The form of the frond is subtriangular-ovate, bi-subtripinnate; pinne lanceolate, caudatcly acuminate, the tcrminal onc clongatecl and very narrow, and the lowest pair mostly bipartite; pinnules horizontal and approximatc, obliquely oblong-ovate, acutc, antrorscly subfalcatc, inferior base cuncate, superior base 
52.-Dentieulatum, Swart\%. Jamaica.

53.-Proximum, Gaudichaud. Brazil.

54.-Laneea, Linneus. Surinan. Rare.

55.- - Pedatum, Limacus. North Ancrica.

56.-Tetragonum, Schiradcr. Brazil. Rarc.

57.- Curvatum, Kaulfuss. Brazil.

58.-Humile, Kunzc. 'Tocachc.

59.-Patens, Willdenow. Caraccas.

60._Lindsæa, Cavanillcs. Quito. A dubious specics.

61.-Angustatum, Kaulfuss. Brazil. A dubious species.

62.-Flabcllulatum, Linnæus. China.

63.- Hispidulum, Swartz. New Holland.

64.-Le Prieurii, N. S. Berbicc.

65.- Affine, Willdcnow. New Zcaland.

66.- * Trapeziforme, Linneus. Wcst Indies.

67._* Cultratum, J. Smith. St. Vincent.

68.-Subeordatum, Swartz. Brazil.

69.-Peruvianum, Klotzsch. Pcru. Handsome.

70.-Mathewsianum, Hooker. Pcru. Rare.

71.-Sinuosum, Gardner. Brazil.

72.-Amplum, Presl. Mcxico.

73.- ${ }^{*}$ Capillus-veneris, Linnæus. England.

74.-AEthiopicum, Linnæus. South Africa. 'This is in cultivation in England, but it approaches so near to assimile that it has not been figurcd. It is a doubtful specics.

75.—*Assimile, Swartz. Van Diemen's Land.

T6.-Pulchellum, Blume. Java.

77.-Fumarioides, Willendow. Bourbon.

78.-Digitalum, Presl. Brazil. Doubtful.

79.-Emarginatum, Bory. Bourbon. Handsome specics.

80.-— Cuneatum, Langsdorff and Fischer. Brazil.

81.-Glaucophyllum, Hooker. M[cxico.

89.-Venustum, Don. India.

83.-Fragile, Swartz. Jamaica.

84.-Excisum, Kunze. Chili.

85.- - Concinnum, H. B. K. Central Amcrica.

86.-Seabrum, Kaulfuss. Chili. A dubions specics.

87.-Chilense, Kaulfuss. Chili. A handsome species.

88.-Sulphureum, Kaulfuss. Chili.

89.-Sessilifotium, Hooker. Peru. A liandsome species. 
90.-Parvulum, Hooker. Galapagos.

91.-IIcnslovianum, Hooker. Galapagos. A handsome species.

92.-Speciosum, Hookcr. Peru. A handsome species.

93.—*Tenerum, Swartz. Jamaica.

94._* Cristatum, Linnæus. Jamaica.

95.-Microphyllum, Kaulfuss. Jamaica.

96.-Kuñeanum, Kaulfuss. Jamaica.

97.-Crenatum, Willdenow. Hispaniola.

98.-Politum, H. B. Cumana. A dubious species.

99.-Pyramidale, Willdenow. America.

100.-Polyphyllum, Willdcnow. South Amcrica. A dubious species.

101.-Macrocladum, Kaulfuss. Peru. Rare.

102.-Wilesianum, Hooker. Jamaica.

103.-Brasiliense, Raddi. Brazil. Under this name there are scveral Forns in cultivation in England; most of them arc found to be intermedium, yct therc are two or thrce apparently diffcrent in many respects, yet as considcrable obscurity hangs over them, they are rescrved for the supplementary volume. It is doubtful whether any of them could be referred to brasilicnsc of Raddi.

104.-Cardiochlena, Kunzc. Caraccas.

105.-Lobbianum, Hookcr. Java.

106.- - Formosum, Brown. Port Jackson.

10\%.- Cunninghami, Hookcr. New Zcaland.

108._- Fulvum, Raoul. Now Zealand.

\section{DUBIOUS SPECIES.}

Rotundatum, Kunze.

Capensc, 'Thunberg.

Dccipiens, Desvaux. Java.

Papyraceum, Desvaux. Mauritius.

Cassioides, Desvaux. 'Tropical Amcrica.

Rotundatum, Desvaux. Peru.

For lengthened descriptions of the above species the reader. is referred to Part V of Sir. W. J. Hooker"s "Specics Filicum." 



\section{GENUS II.}

\section{ON YCHIUM. Kaulfuss.}

'IHE gonus Onychium is small, and although Fec in his "Genres de la Famille des Polypodiacecs" cnumcrates the following, still only one, namely $O$. lucidum, appears to be cultivated in Great Britain.

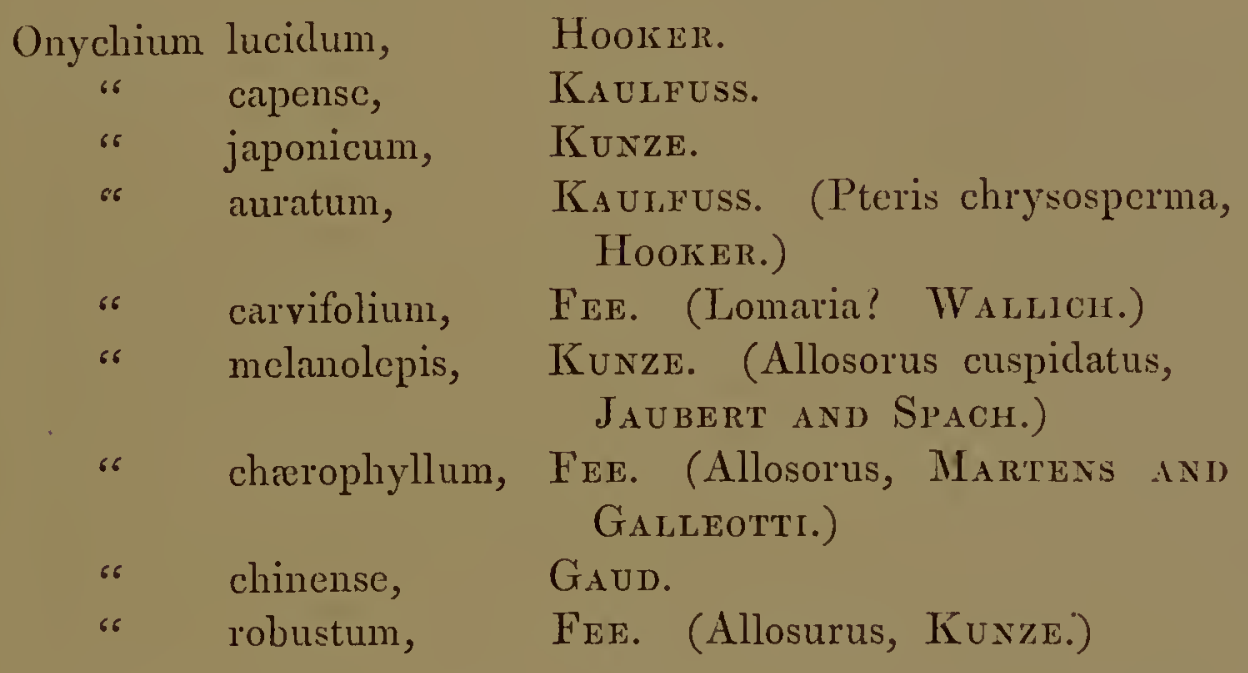

Fronds deltoid, clongate, acuminatc, dccompound; veins simple, direct, frec on their apices, combined by a transverse sporangiferous receptacle, which is formed in the axis of a linear and slightly intramarginal indusium. Indusium planc, the free margins of cach conniving over the midrib, and splitting open along the centre, as it were by a longitudinal suture. Sori short, linear, continuous, evcntually becoming confluent, and covering the whole disc between the two indusia. Rhizoma crecping.

Formerly Onychium was considered by some authorities a Pteris, and by others a Lomaria, but the distinct habit and dissimilar structure of the fertile fronds have induced botanists to form a genus Onyychizm. This genus is distinguished from Pteris by the fertile segments being so narrow that the two 
sori are soon confluent, and the free margin of the two indusia wrap over the midrib, and the sori eventually covers the whole disc, as in the Acrostichums. It is distinguished from Lomaria in the sporangia being seated in the immediatc axis of thc indusium, (in which respect it rcsemblcs Pteris, whilst in Lomaria the reccptaclc is broad, and occupics a great portion of the space betwcen the midrib and the axis of the indusium. 








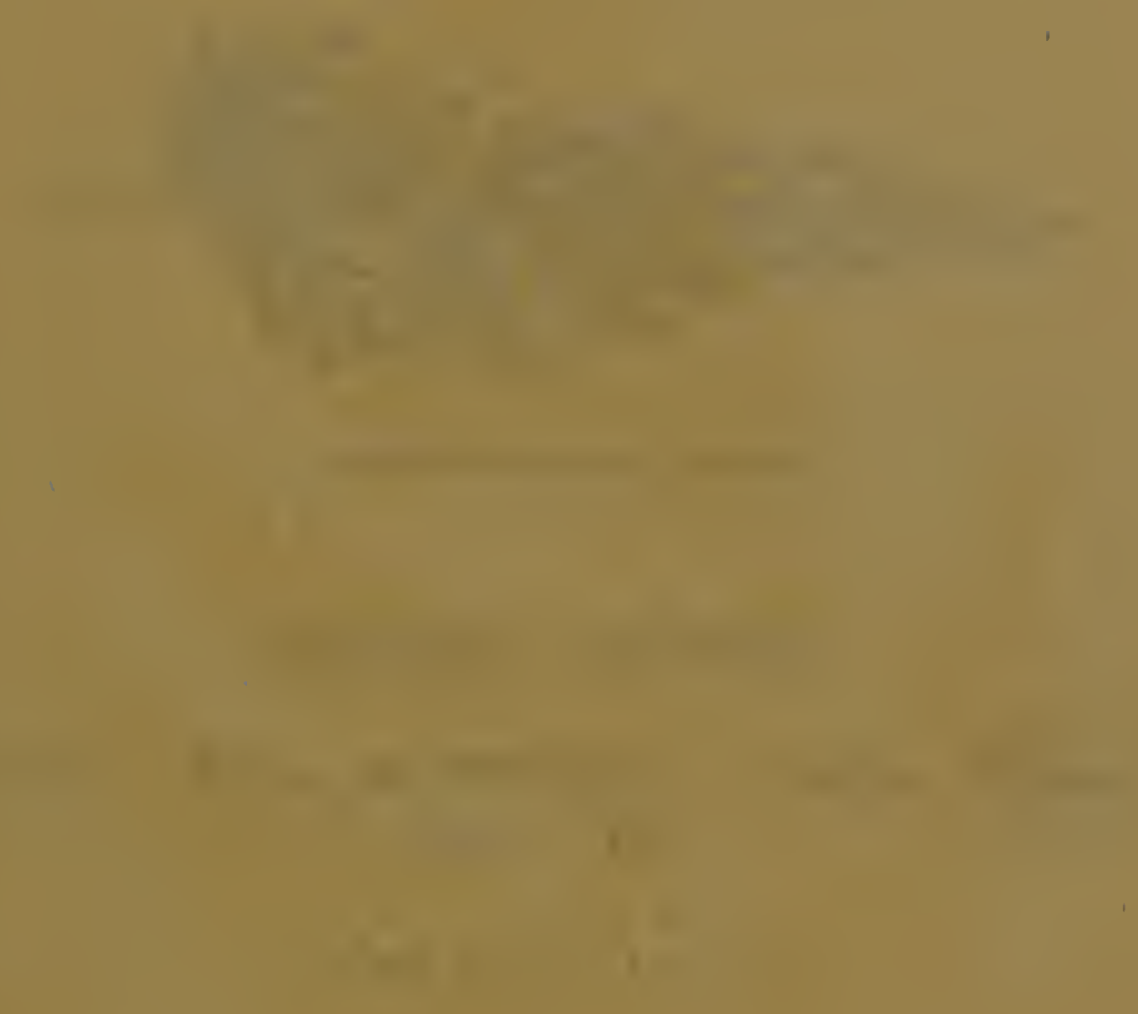

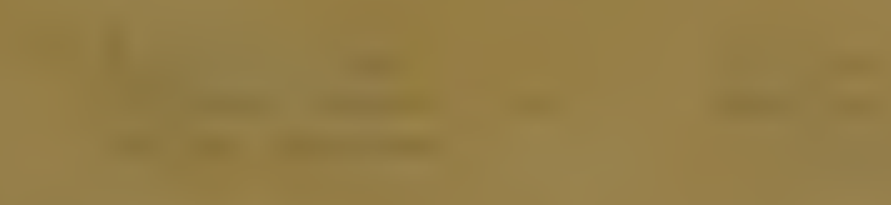

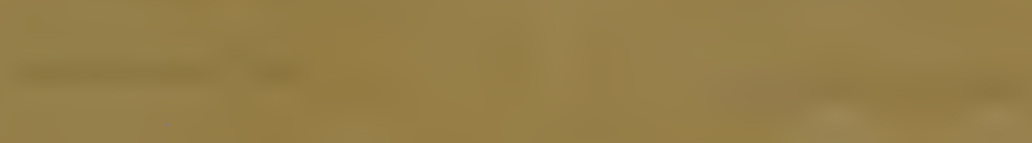

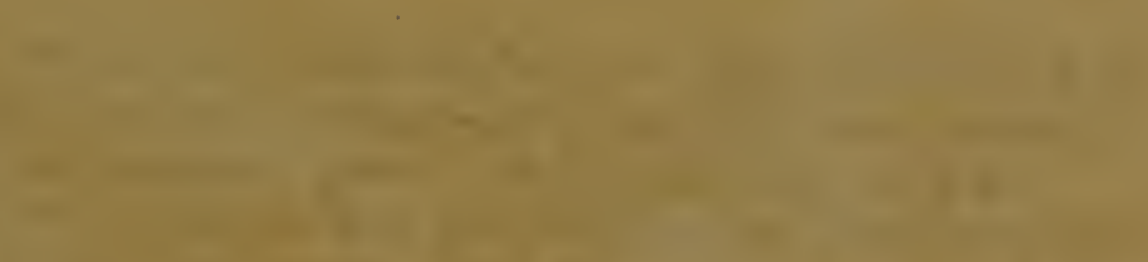

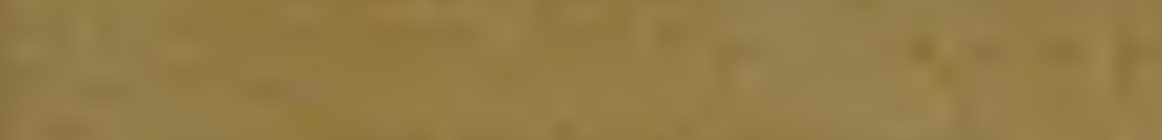

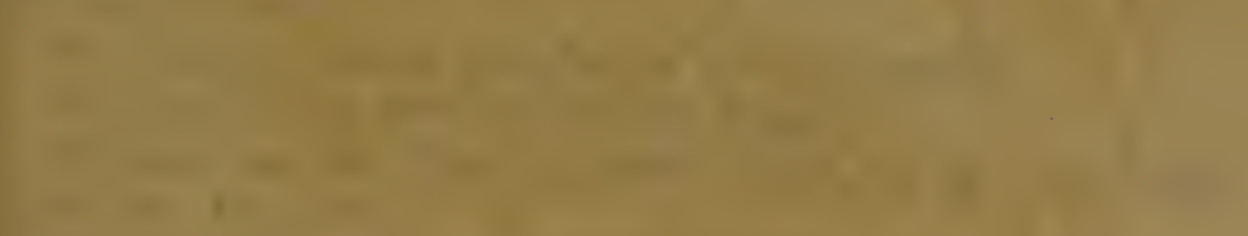

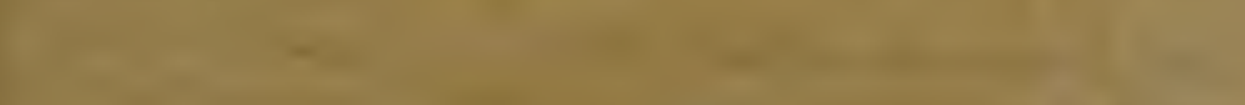

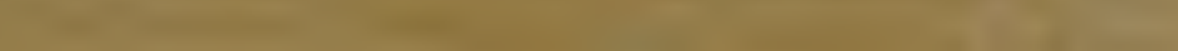

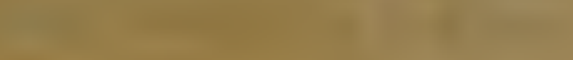

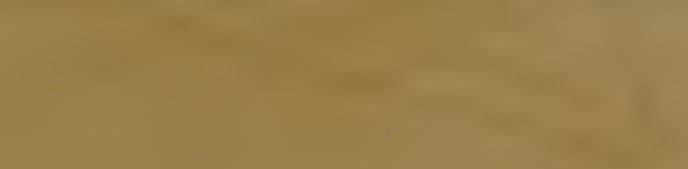




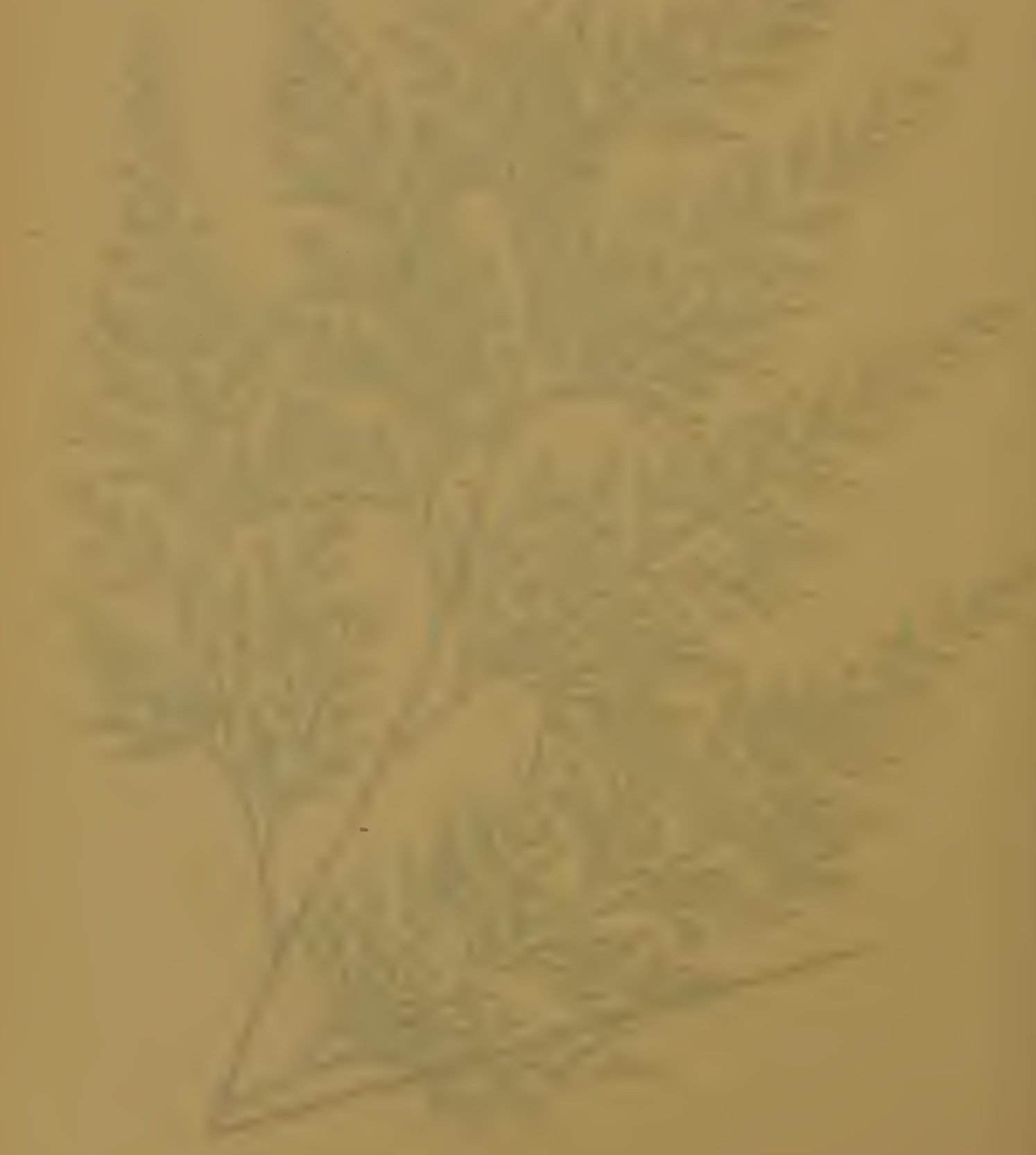




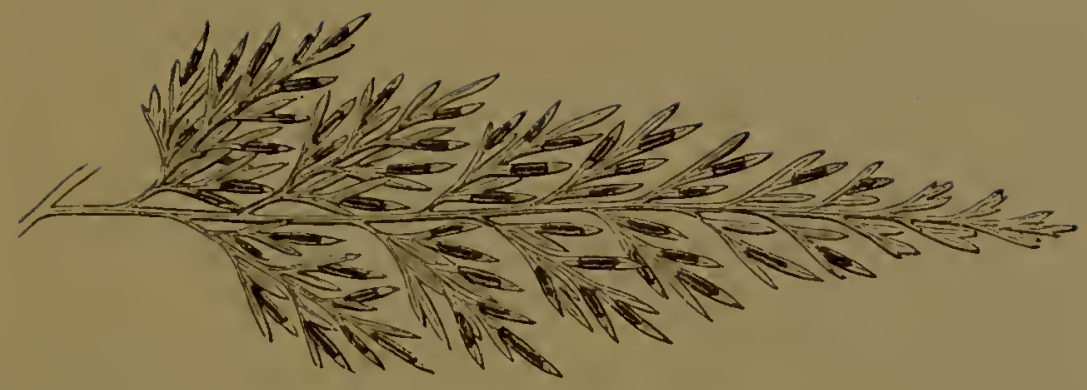

Portion of maturc Frond-under side.

\section{ONYCHIUM LUCIDUM.}

\section{Sprengel. Moore and Houlston. J. Simti. Hooker. Kunze. FeE.}

PLATE XXIII. VOL. IMr.

\author{
Leptostegia lucida, \\ Cheilanthes lucida, \\ Onychium japonicum,
}

Onychium-A Claw.
D. Dox.

WALLICII.

Of Gardens.

Lucidum-Shining.

A BFAUTIFUt, slcnder-looking, yet vigorous-growing Fern, requiring as little management as possiblc, and producing a large and handsome plant, if afforded abundant pot-room.

Easily propagated, botl by divisions of the crecping rhizoma and from sporcs, young plants coming $u p$ in all the pots in its ncighbourhood.

An crergrecn warm grecnhousc or stove species.

A native of the East Indies and Nepal.

Received at the Royal Gardens, Kcw, in the ycar 1844, from Mr. II. Lowc.

The fertile fronds arc glabrous, slcncler, with remote pinna, the pinnules triangular in form; segments small, lincar-acuminate, 
and very narrow. The sterile fronds are glabrous, slender, somewhat triangular, triquadripinnatc, the pimules being also triangular; scgments long, and the apcx dentatc. Both fronds arc latcral, and adherent to a creeping rhizoma. The stcrile fionds are usually a foot in length, and the fertile ones fiftecn inches; a plant in my collcction has fronds much largcr, most of them from two feet to two feet and a half.

The stipes a foot in length, and bright grecn in colour.

Sori linear, continuous, extcnding along cach scgment, but ncither reaching apex nor basc, eventually becoming conflucnt. For plants of this spccies I an indebted to Messis. A. Henderson, of Pinc-apple Place Nurscry, and to Messis. Rollisson, of Tooting.

It is in the Forn Catalogues of Messis. Veitch, Jun., of Chelsca; Masters, of Canterbury; Rollisson, of Tooting; A. Henderson, of Pinc-apple Place; Sim, of Foot's Cray; Vcitch, of Excter; Kennedy, of Covent Garden; and Cooling, of Derby.

The illustration is from a plant in my own collection. 


\section{GENUS III.}

\section{PLATYLOMA. J. SмITH.}

Thrs family takes its name from the broad sori, namely, platys, broad, and loma, a margin.

Fronds pinnate or bipinnate. Stipes usually ebeneous, smooth, pillose, or squamulous. Pinne articulated with the rachis.

Sori linear-oblong, continuous, eventually becoming confluent, and forming a broad belt round the margin. Indusium narrow, and transversely attached to the outer margin of the compound reccptacle.

'Veins forked; venules dircet, their apices being free and sporangiferous.

In habit they mostly vary but little from those of Cassebeera and Adiantum, agreeing with the former in the ebeneous character, yet differing from it in the broad sorus; and differing from the latter by the compound receptacle of Platyloma not being so much changed in its texture, nor reflexed, as is the casc with Adiantum.

Although a small genus, still it is as interesting as perhaps any other of the tribes of Ferns. Some authors adopt the name of Pellea instead of Platyloma. Fee cnumerates a score species, whilst Moore gives eight as cultivated in this country. Kunze, who places them as Allosorus, gives fifteen species, and in these he includes the British A. erispus.

Amongst Platyloma no one can help being struck with the beauty of ealomelanos of Presl, Alexuosa of Kaulfuss, the rotundifolia of Kunze, or the ternifolia of Kunze.

'This family are very subject to the attack of thrips, more especially the species fulcata and rotundifolia.

We have no British example. 


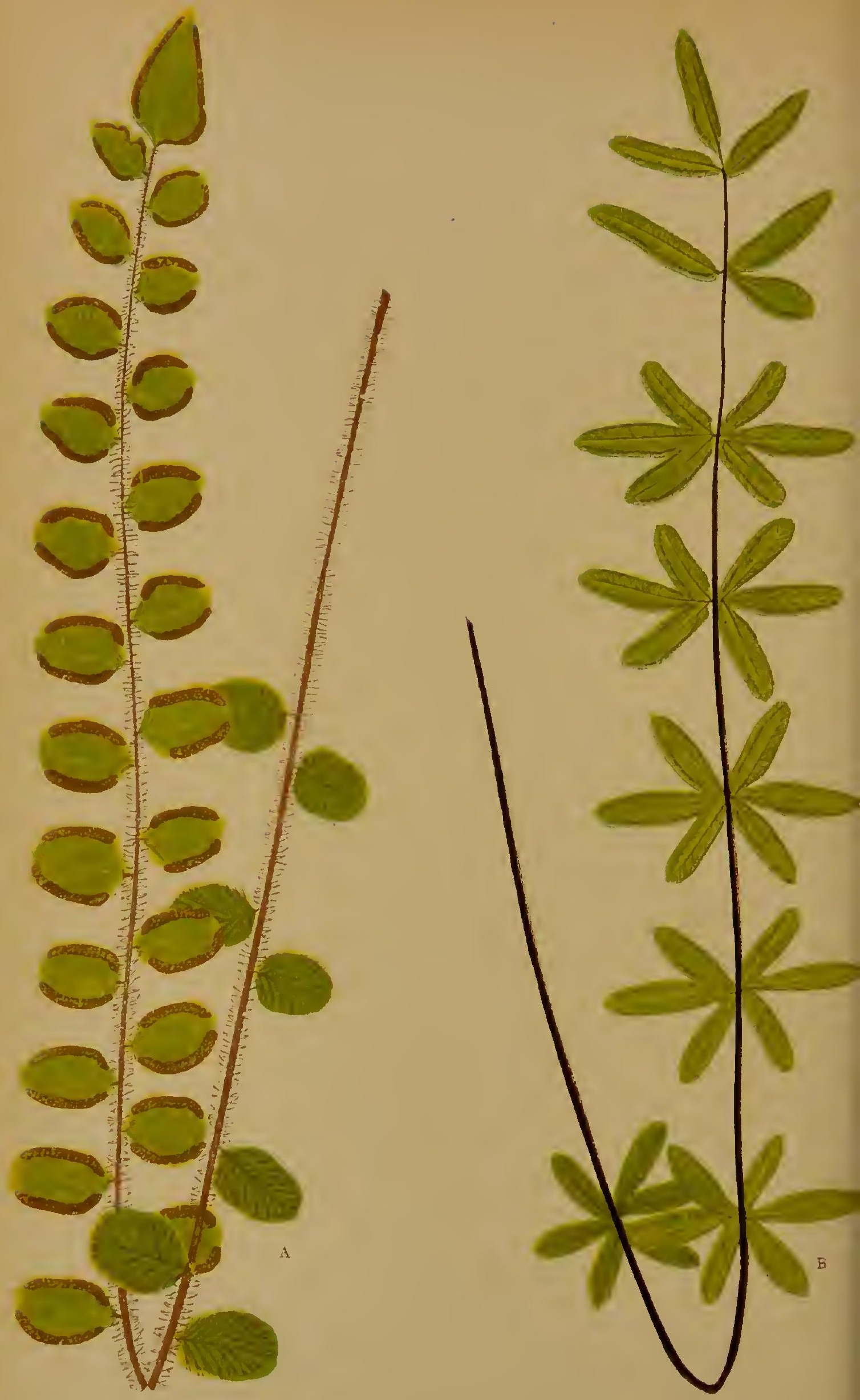



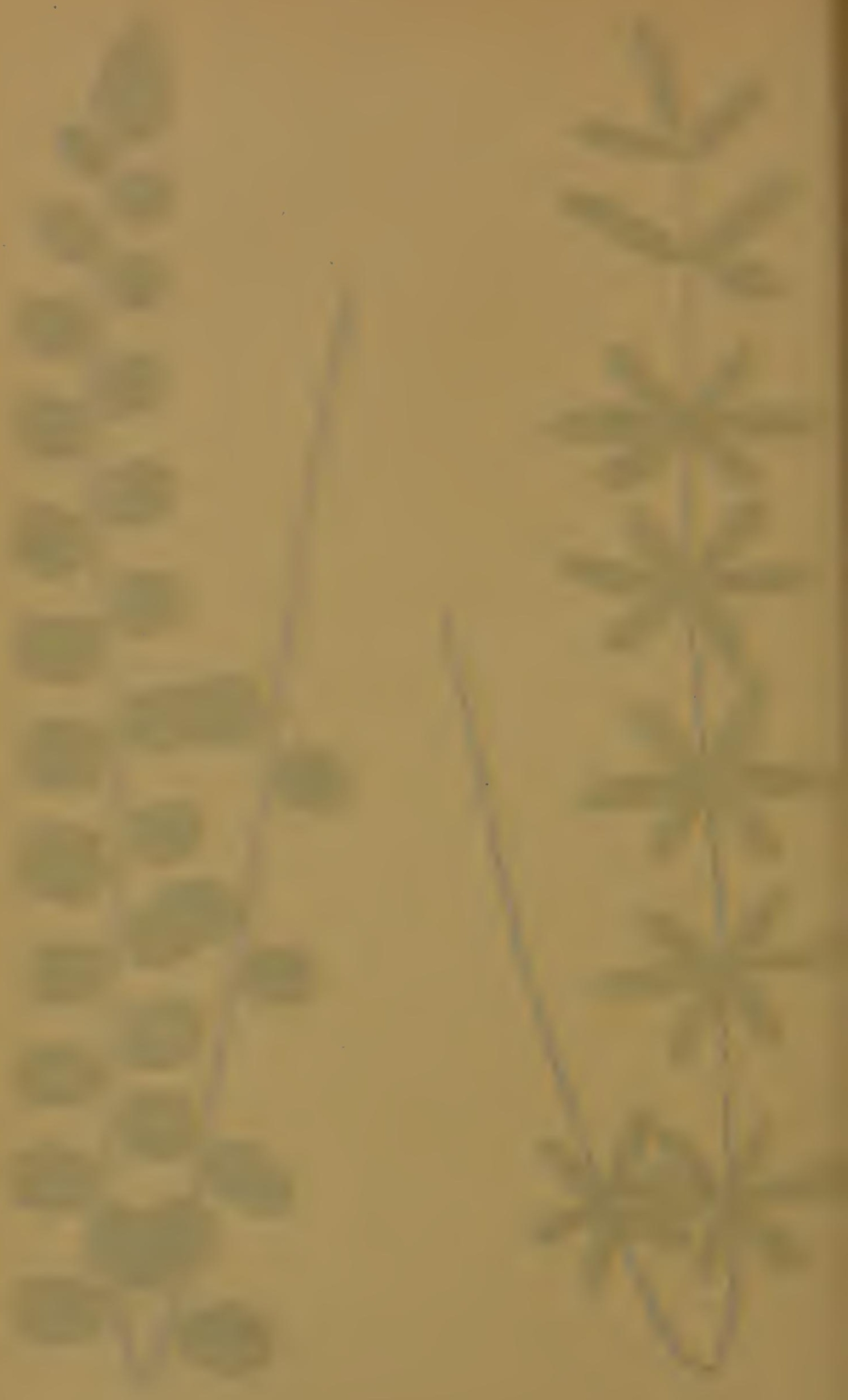




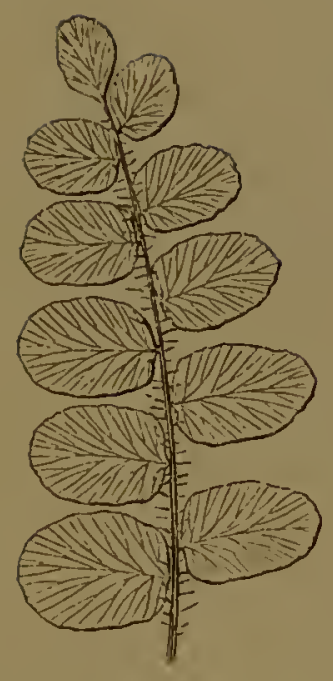

Portion of barren Frond-upper side.

\section{PLATYLOMA ROTUNDIFOLIA.}

J. Smith. Forster. Moore and Houlston. Schikuilr.

PLATE XXIV.-A. VOL. III.
Allosorus rotundifolius,
KuNZE.
Pteris rotundifolius,
Forster.

Platyloma-Broad-edge.

Rotundifulia-Round-leaved.

A BeaUtifux dwarf pendulous species, descrving of universal cultivation. A species readily grown and propagated, and capable of making a very handsome plant, if allowed plenty of pot-room.

An cvergreen grecnhouse Fcrn.

Native of New Zcaland.

Introduced into the Royal Girdens, Fiew, by Mr. John Elgerley, in the year 1841 .

'The fronds arc linear-pinnate, reclining, the pinne being 
sub-rotund or oblong-elliptical in form, rather obtuse, cordate at the base, glabrous, coriaceous, slightly crenate on the margin.

Rachis and stipes densely crowderl with scales of a brown colour, lateral, adhering to a crecping rlizoma.

Length of frond from twelve to eighteen inches; colour dull green.

Sori linear, continuous, very broal. Indusium very narrow.

For plants of this species my thanks are due to Mr. Ingram, of the Royal Gardens, Windsor, and to Mr. Norman, of IIull; and for fronds to Mr. Henderson, of Wentworth; Mr. Clark, of the Glasgow Botanic Gardens; Mr. Gray, of St. 'Thomas', Exeter; Mr. Jeans, of Grantham; Mr. Norman, of Hull; and Messrs. Booth, of Hamburg.

It is in the Fern Catalogues of Messrs. E. G. Henderson, of St. John's Wood; Veitch, Jun., of Chelsea ; Rollisson, of 'l'ooting; A. Henderson, of Pine-apple Place; Parker, of Holloway; Sim, of Foot's Cray; Stansfield, of 'Todmorden; Veitch, of Excter; Kemedy, of Covent Garden; and Cooling, of Derby.

The illustration is from a plant in $\mathrm{my}$ own collection. 


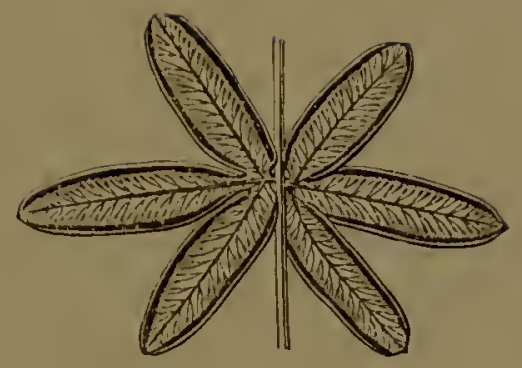

Portion of mature Frond - under side.

\section{PLATYLOM.A TERNIFOLIA.}

J. Smitil. Moore and Houlston. Hooker and Greville.

PLATE XXIV.-B. VOL. JII.

\author{
Pteris subverticillata, \\ Pellau ternifolia, \\ Pte:is \\ " peruviana, \\ " subverticillata, \\ Allsorus subverticillatus, \\ .. ternifolius,
}

Platyloma-Broad-edge.

\author{
Cavanilues. \\ Link. J. SiIth. Fer. \\ Cavanilles. Hooker de Greville. \\ Poir. \\ SWARTZ. Willendow. \\ Prest. \\ KuNZE.
}

A strikixgly beautiful rather pendulous Fern, whose pinnules are so placed as to form hexagonal stars one above another all along the frond. It is a dwarf species, and perhaps less casily cultivated than the other members of this lovely family, yet when properly managed makes a beautiful little plant, and being so different in form and gencral appearance as to strike any one who sees it with admiration.

lieceived at the Royal Gardens, Kew, from Mr. I). Caneron, in the year 1841 .

An evergreen stove Fern.

Native of Mexico. 
Fronds glabrous, linear, pinnate, reelining, pinnx opposite or alternate, about ten pairs, sessile, trilobed, the pinnæe nearest the apex are usually bilobed, eordate at the base, eoriaceous, having a eartilaginous margin: ultimate pinne trilobed.

Rachis and stipes purple, being eovered with a plum-like bloom; stipes pubeseent, with long and thin whitish seales; terminal, adherent to a short ereeping rhizoma, which is sealy.

Sori linear, eontinuous; indusium very narrow.

Length of frond from twelve to eighteen inehes; colour a blue green.

My thanks are due to Messrs. Rollisson, of Tooting, for plants of Platyloma ternifolia, and to Mr. Norman, of Hull, and Mr. Henderson, of Wentworth, for fronds.

It is in the Fern Catalogues of Messrs. Rollisson, of Tooting; Parker, of Holloway; Sim, of Foot's Cray; and Booth, of Hainburg.

The illustration is from a plant in my own eolleetion. 



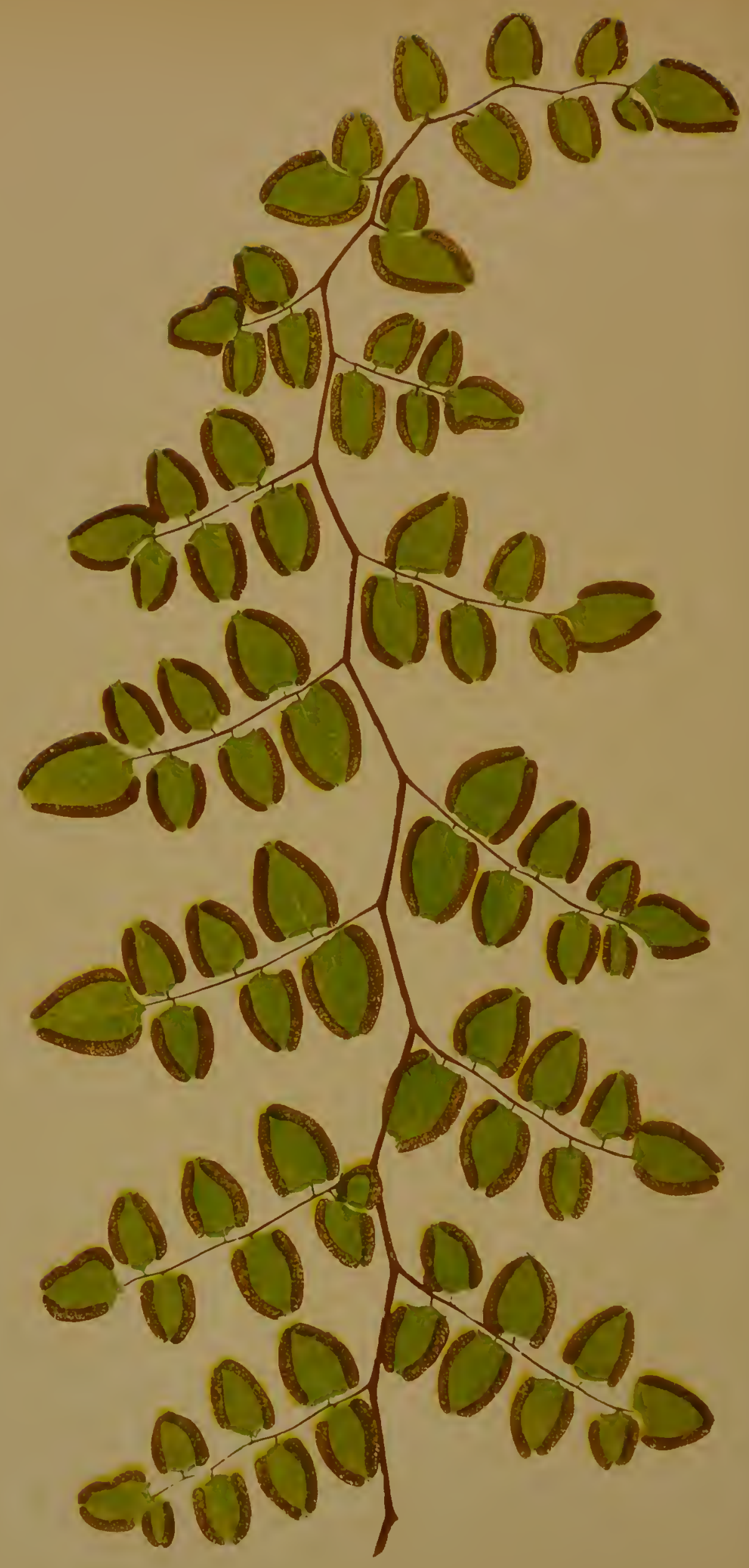




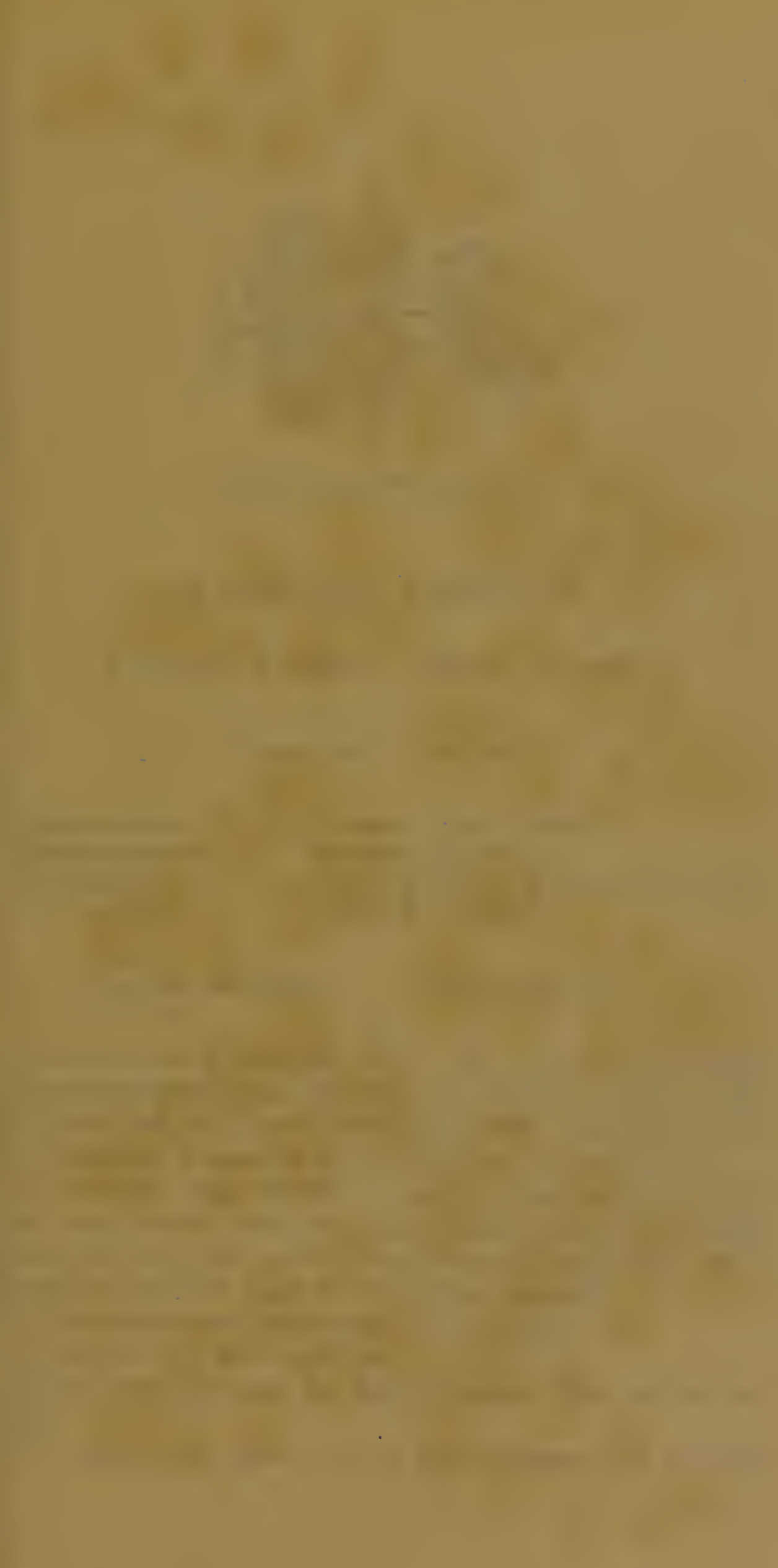




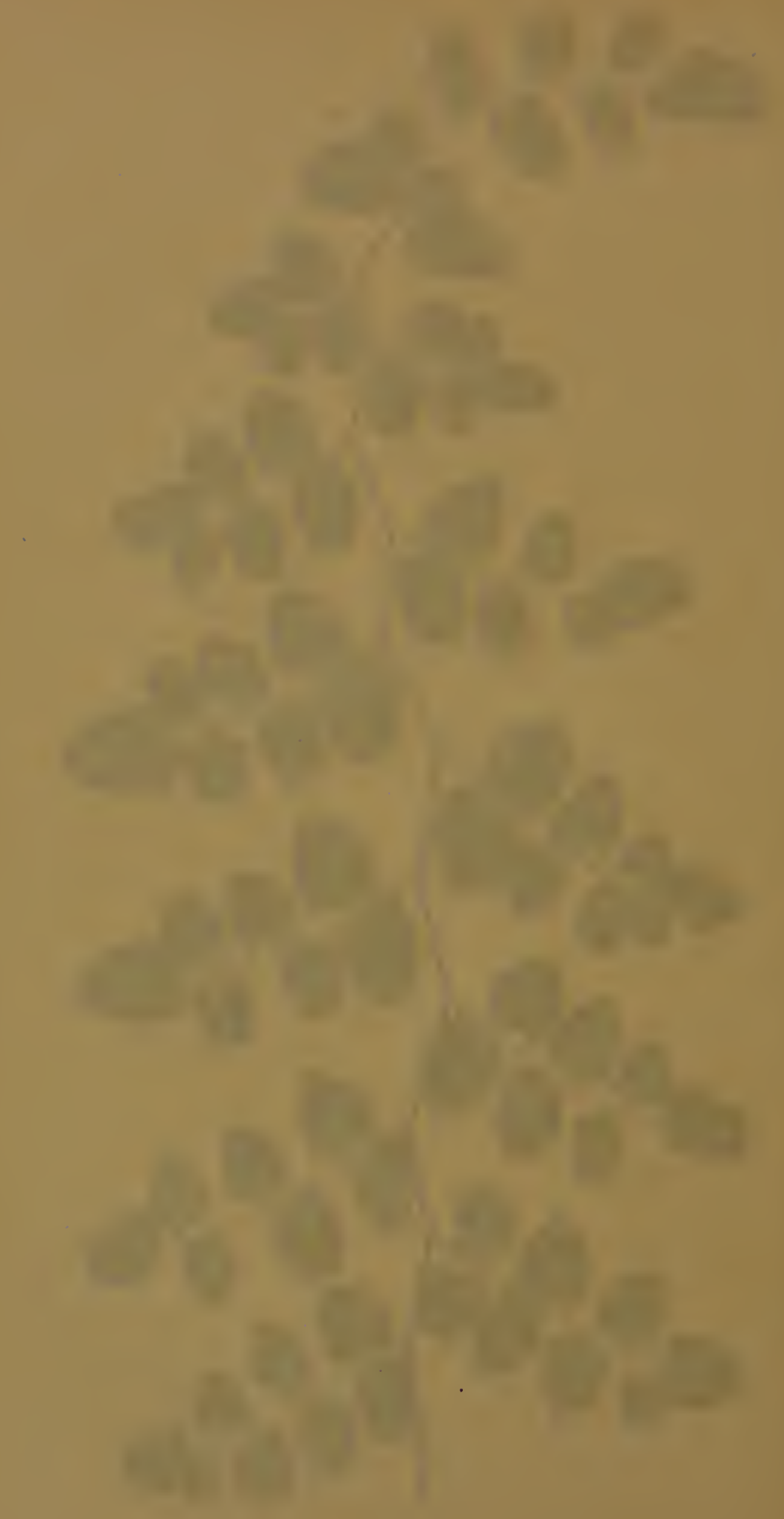




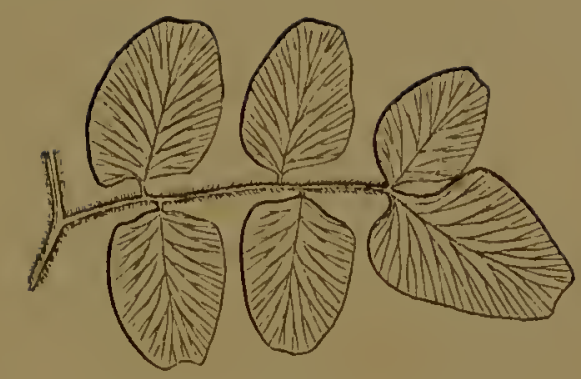

Portion of mature Frond-upper side.

\section{PLATYLOMA FLEXUOSA.}

\section{J. Shitit. Kaulfuss. Moore. Hooker.}

PLATE XXT. VOL. III.

$\begin{array}{ll}\text { Pella flexuosa, } & \text { Linnæers. Fez. J. Suith. } \\ \text { Allosorus flexuosus, } & \text { Kaulfuss. Kunze. } \\ \text { Pteris flexuosa, } & \text { Prest. Kaulfuss. Hooker. Willdenow. } \\ \text { " cordata, } & \text { Link, (not Cavanilite.) }\end{array}$

Platyloma-Broad-edge. $\quad$ Flexuosa-Zig-zag.

ONE of the most beautiful of the exotic Ferns; its climbing habit, the splendid green colour of its pinnules, elegant habit, and broad dark sori are all recommendations that should place the Platyloma flexuosa in every collection, however small.

It docs not secm difficult to manage, but should be kept clear from thrips, which seem particularly fond of the Platylomas, and can soon weaken the plants so materially, that it occupies months for them to regain their strength.

A deciduous warm greenhouse or stove Fern.

Native of Peru and Columbia.

Raised from spores at the Royal Gardens, Kew, in the year 1838.

The fronds are three or four times pinnate, the branches 
being in pairs, about a quarter of an ineh apart, and eacis pair three inehes apart; somewhat twining in labit, witl alternate zig-zag pubescent branehes. The pinnules, which are small, are ovate in form, glabrous, membranous, semitransparent, deeiduous, eordate at the base, the margin being cartilaginous.

Rachis and stipes green when young, eventually beeoming brown, lateral, adherent to a ereeping rhizoma.

Length of frond from four to six feet; eolour delicate pale green.

Sori linear, continuous, at first black, then changing to reddish brown, not eontinued ronnd the apex or base. Indusium very narrow.

My thanks are due to Mr. Norman, of Hull, and to Mr. Stratton, of the Cambridge Botanic Gardens, for plants of this Fern; and to Mr. Norman, and to Mr. Hendersou, of Wentworth, for fronds.

It is in the Fern Catalogues of Messrs. Veitch, Jun., of Chelsea; Booth, of Hamburg; Rollisson, of Tooting; Parker, of Holloway; A. Henderson, of Pine-apple Plaee; Sim, of Foot's Cray; Stansfield, of Todmorden; and Kennedy, of Covent Garden.

The illustration is from a plant in my own collection. 



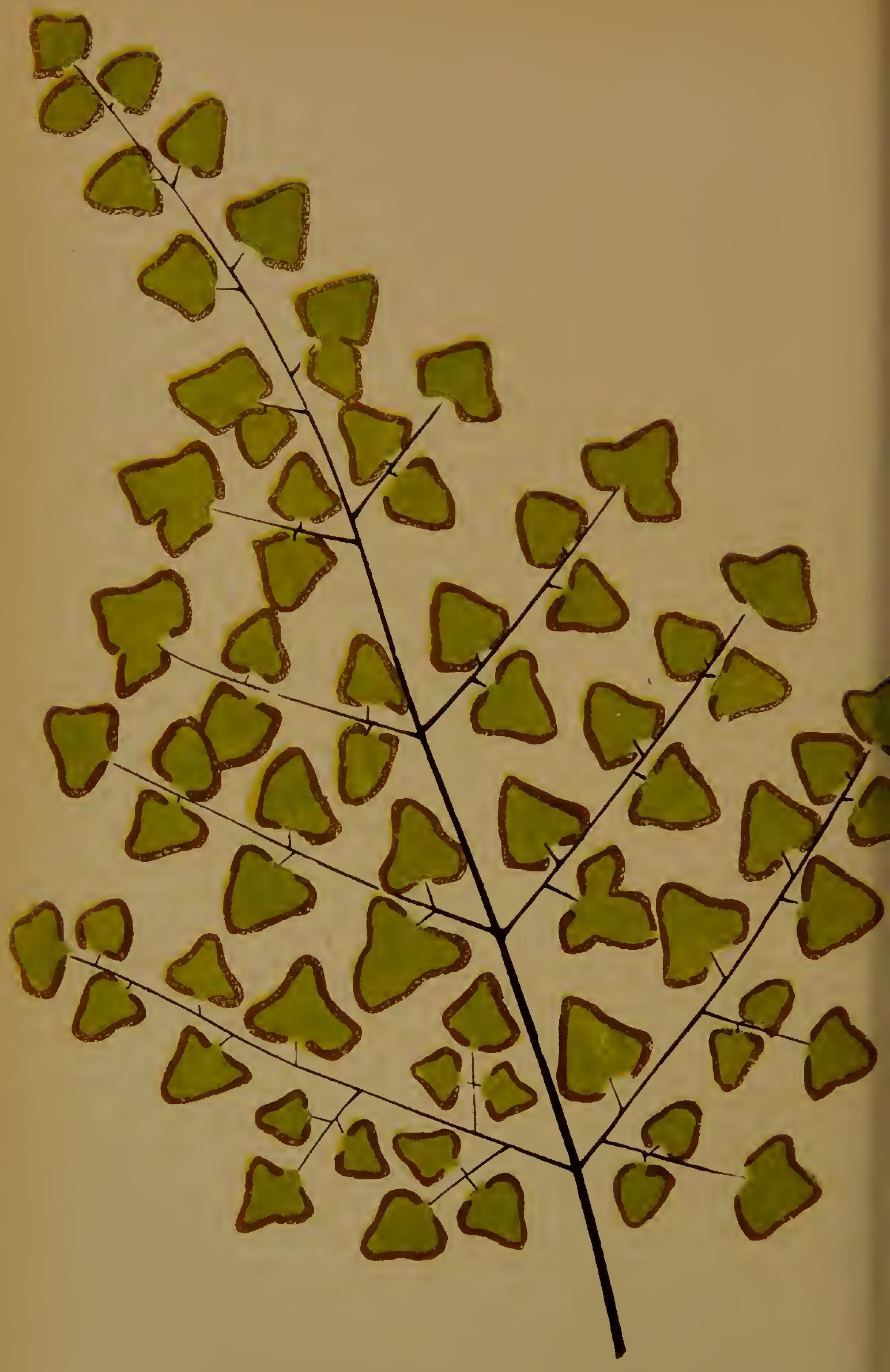




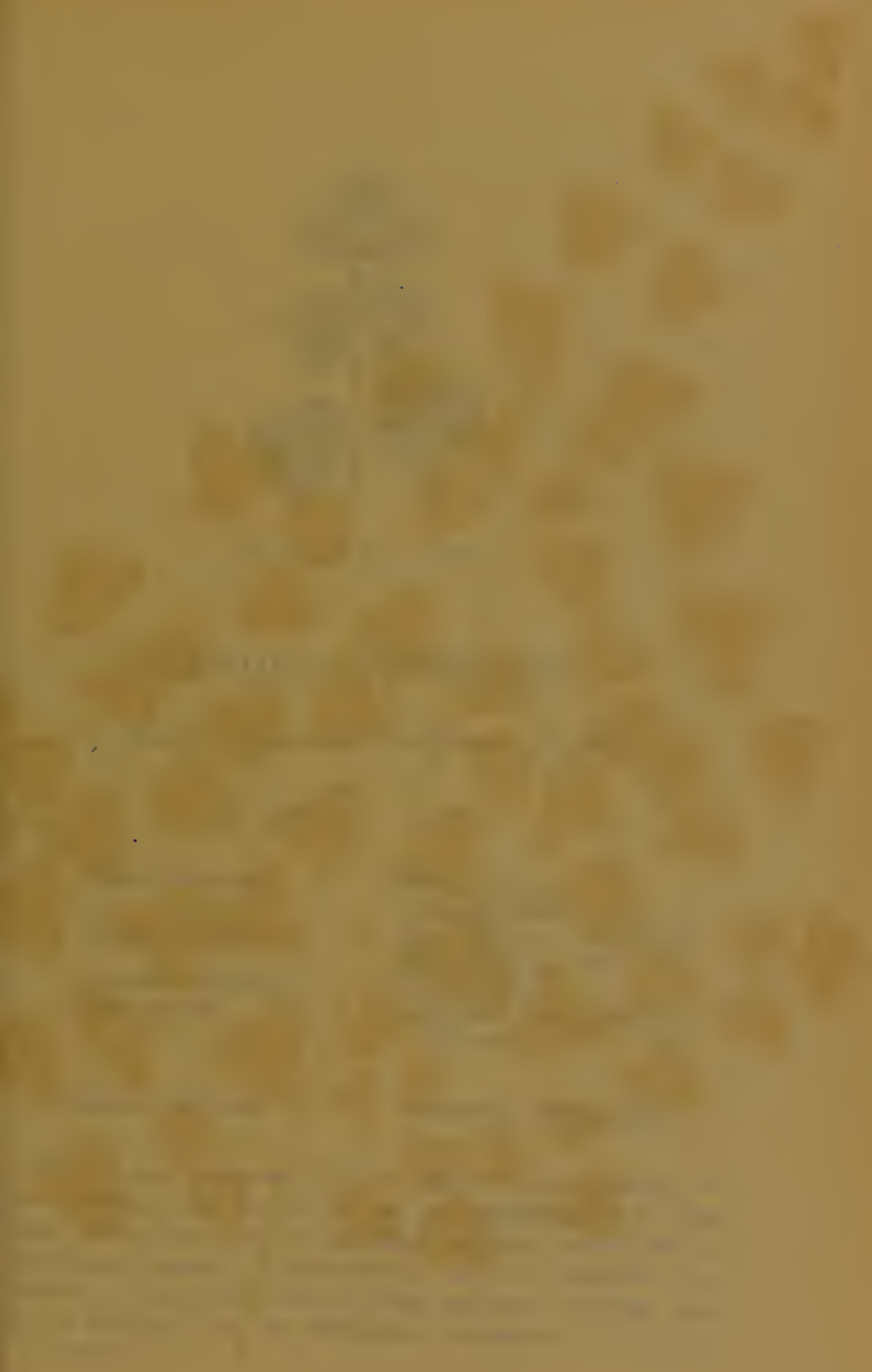




\section{$x=1$}

4 - 15

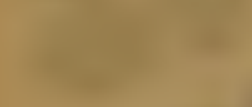
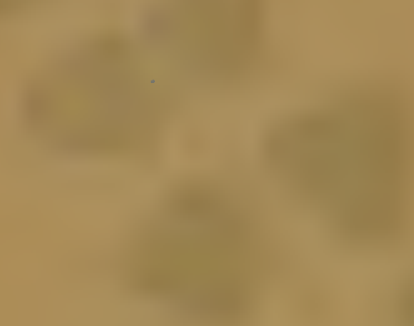

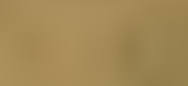

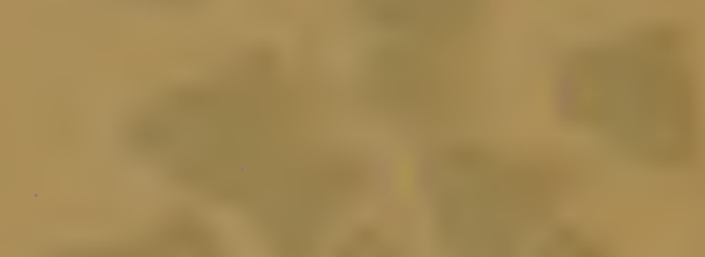

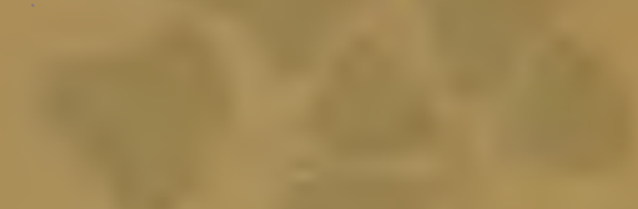

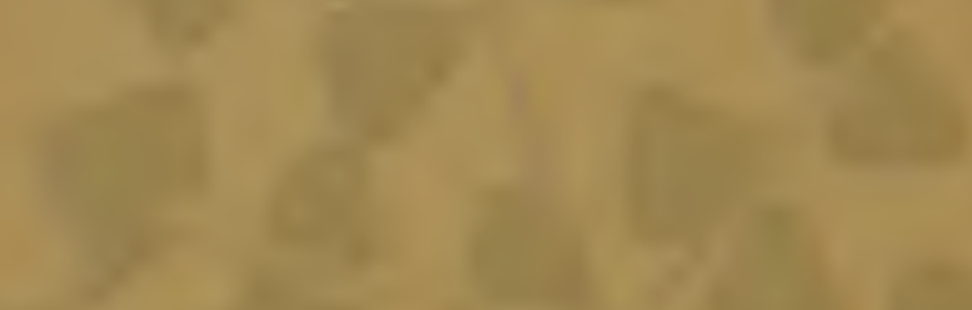

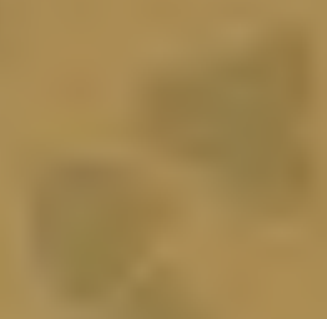

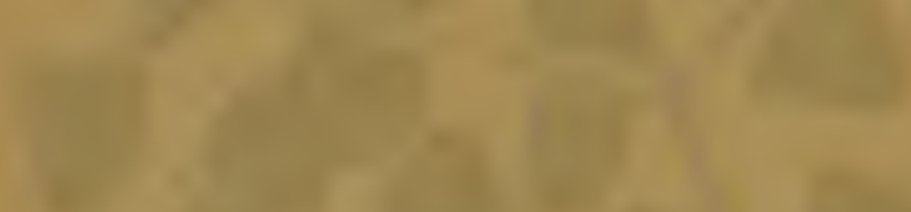
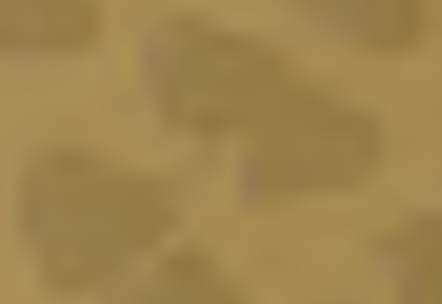

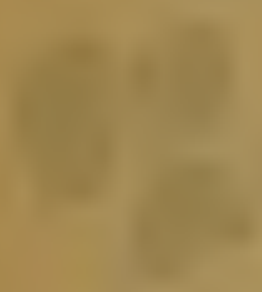

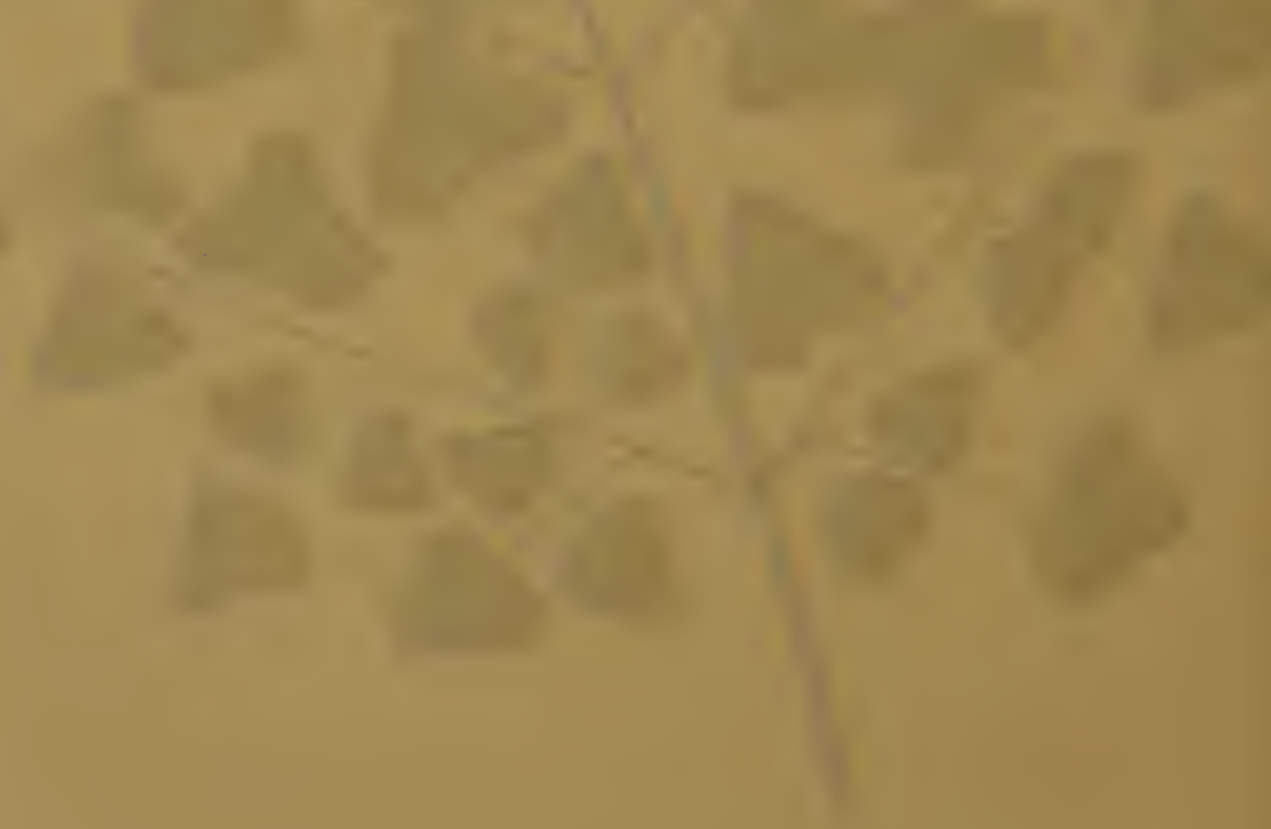




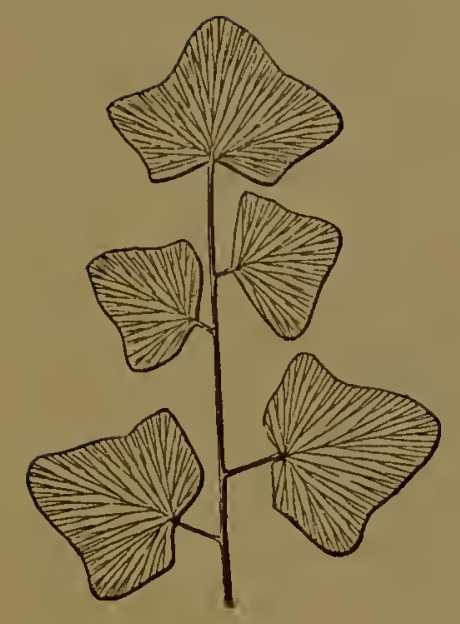

Portion of barren Frond-under side.

\section{PLATYLOMA CALOMELANOS.}

\section{J. Smith. Moore and Houlston. Swartz.}

PLATE IXYI. VOS. III.

$\begin{array}{cl}\text { Pteris calomelanos, } & \text { Presl. Swartz. } \\ \text { " } & \text { Schlechtendal. } \\ \text { Pellaa calomelanos, } & \text { Link. Swartz. Wrlidenow. } \\ \text { " } & \text { Schlechtendal. FeE. } \\ \text { Allosorus calomelanos, } & \text { Prest. Kunze. } \\ \text { Pteris hastata, } & \text { Thunberg, (not of Linn \&us or } \\ & \text { Swartz.) }\end{array}$

Platyloma-Broad-edge. Calomelanos-Beautiful-dark.

$W_{E}$ are apt to expend all our praise on one species, so that nothing shall be left to say in commendation of that which follows our greatest favourite; we have spoken thus of Platyloma flexuosa, $P$. rotundifolia, and $P$. ternifolia, yet whatever we may have said of them our meed of praise must not be withheld from the Platyloma calomelanos; its name is VOL. III. 
enough to pronounce it beautiful, and ccrtainly no one can hclp admiring this delicate-looking species.

An evergreen warm grcenhouse species.

A native of the Cape of Good Hope.

Received at the Royal Gardens, Kew, from Mr. Henderson, in 1843.

The fronds are glabrous, deltoid, glaucous, bipinnate, the pinnules deltoid coriaceous, cordate at the base, sub-trilobate, with a narrow cartilaginous margin.

Stipes covered with scales near the base, ebeneous, terminal, attachcd to a creeping short rhizoma.

Length of frond twelve inches; colour bluish green.

Sori continuous round every fertile pinnule. Indusium very narrow.

I am indebted to Mcssrs. Booth, of Hamburg, for a plant of this species; and to Mr. Henderson, of Wentworth, and to Mr. Norman, of Hull, for fronds.

It is in the Fern Catalogues of Messrs. Parkcr, of Holloway; Sim, of Foot's Cray; Osborn, of Fulham; Kennedy of Covent Garden; Veitch, of Chclsea; and Booth, of Hamburg.

The illustration is from a frond forwarded by Mr. Norman, of Hull. 



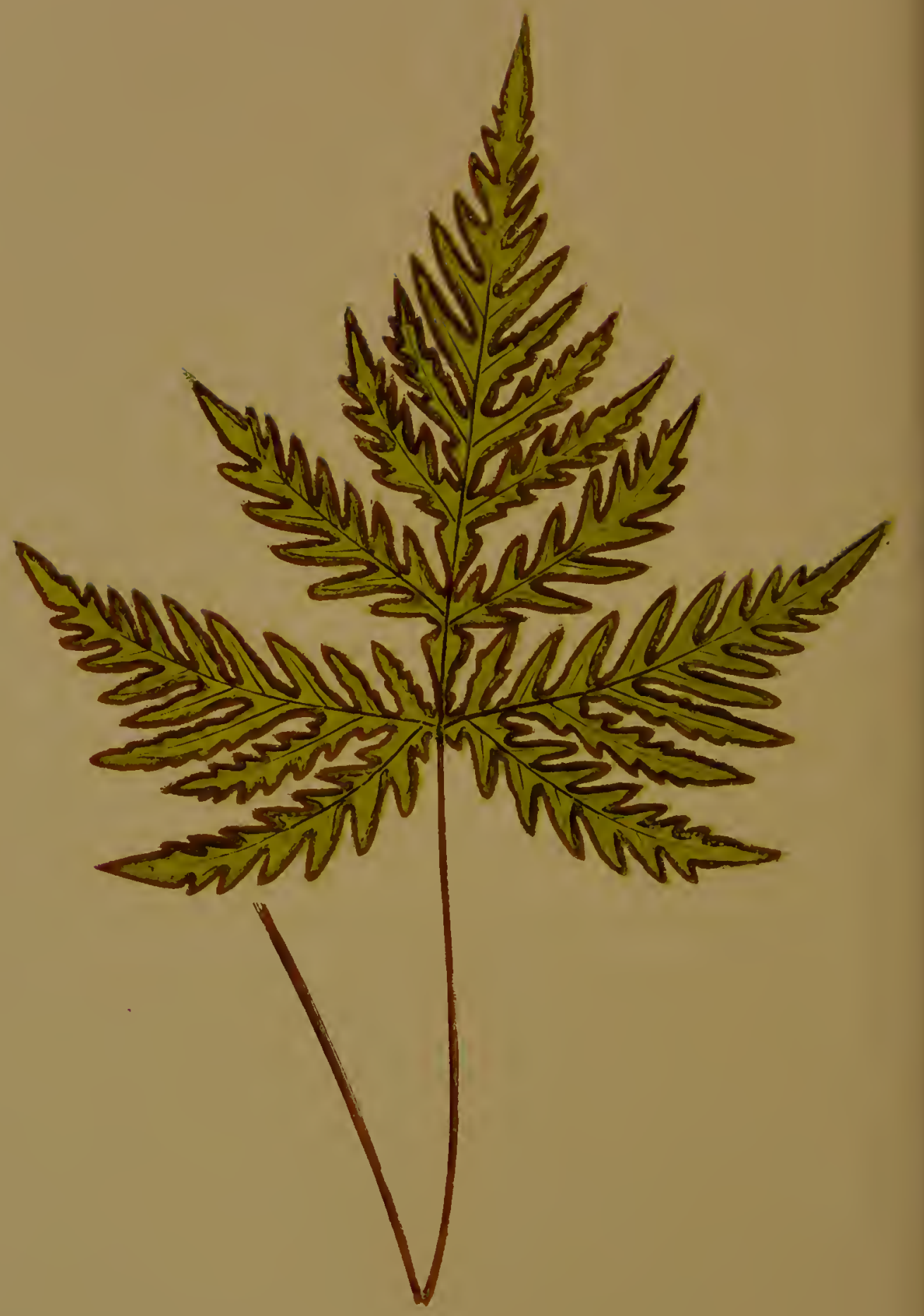




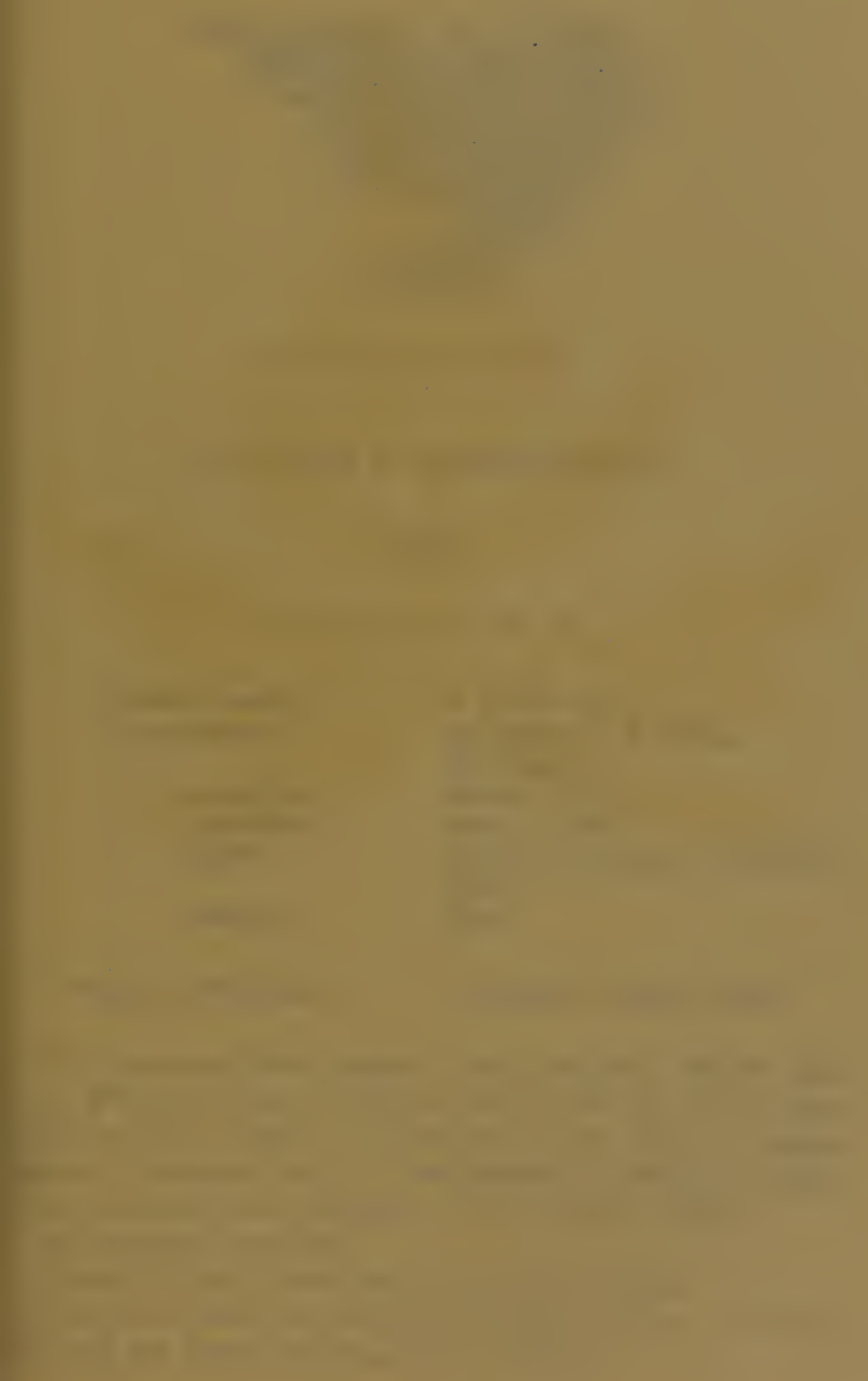





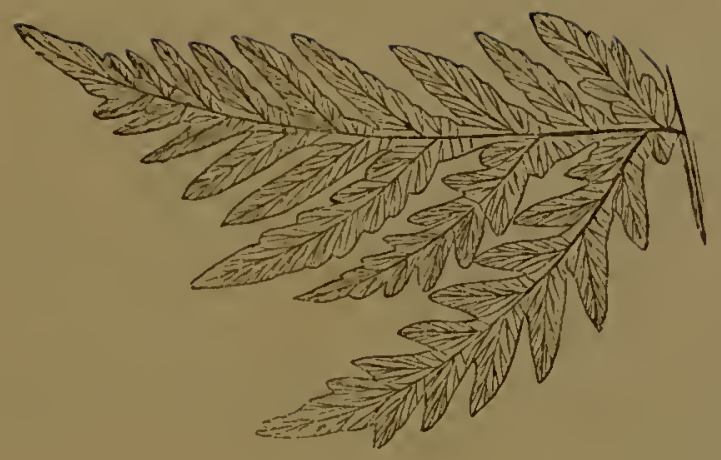

Portion of mature Frond-upper side.

\section{PLATYLOMA GERANIIFOLIA.}

LOWE.

PIATE XXYII. TOI, III.

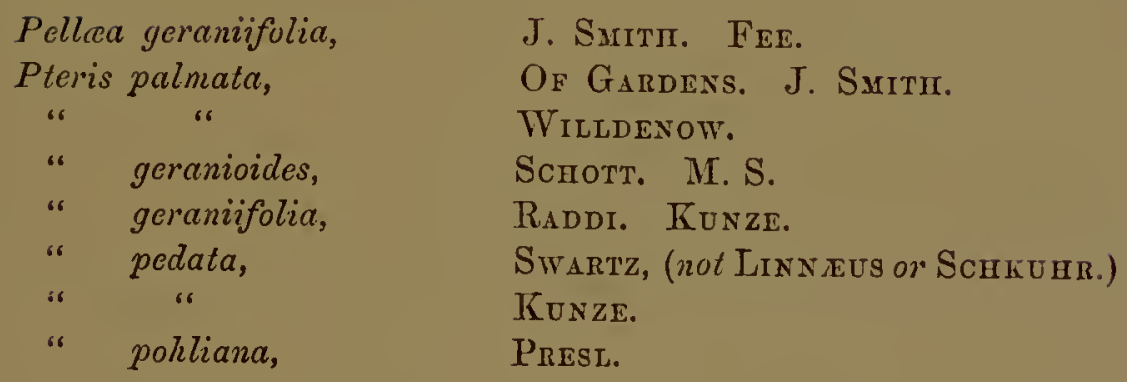

Platyloma-Broad-edge. Geraniifolia-Geranium-leaved.

Av interesting dwarf species, which has bcen looked'upon as a Pteris by most botanists, but placed in the present family by Mr. J. Smith. It appears to be rather a delicate species to cultivate, yet it is not difficult to raisc from spores. Young plants in the secd-pans will bear fertile fronds.

An cvergreen stove Fern.

Native of Brazil, India, and the Islancl of Java.

Introduced into this country in 1816, according to Kunze, and into the Royal Gardens, Kew, in 1838.

VOL. III. 
Fronds glabrous, triangular, five-parted, the scements drooping, pinnatificl, lincar-acuminate.

Rachis and stipes cbencous, terminal, adherent to a rhi which is somewhat erecping.

Sori recldish brown, oblong or lincar, and are continuous; indusium narrow.

Length of frond from six to ten inches, eolour light green.

For plants of this Fcrn, I am indebted to Mr. IIcnderson, of Wentworth; and for fronds, to Mr. Norman, of Hull; Miss Carr, of Qualt Rectory, near Bridgnorth, Salop; and to M. Schott, Director of the Imperial Botanic Gardens, at Sehonbrünn, near Vienna.

It is in the Fern Catalogue of Messrs. Booth, of Hamburg. Probably, in most instances, the speeies mentioned in English Catalogues as Pteris pedate and Dryopteris pedata, will be this Fern.

The illustration is from a plant in my own eollection. 




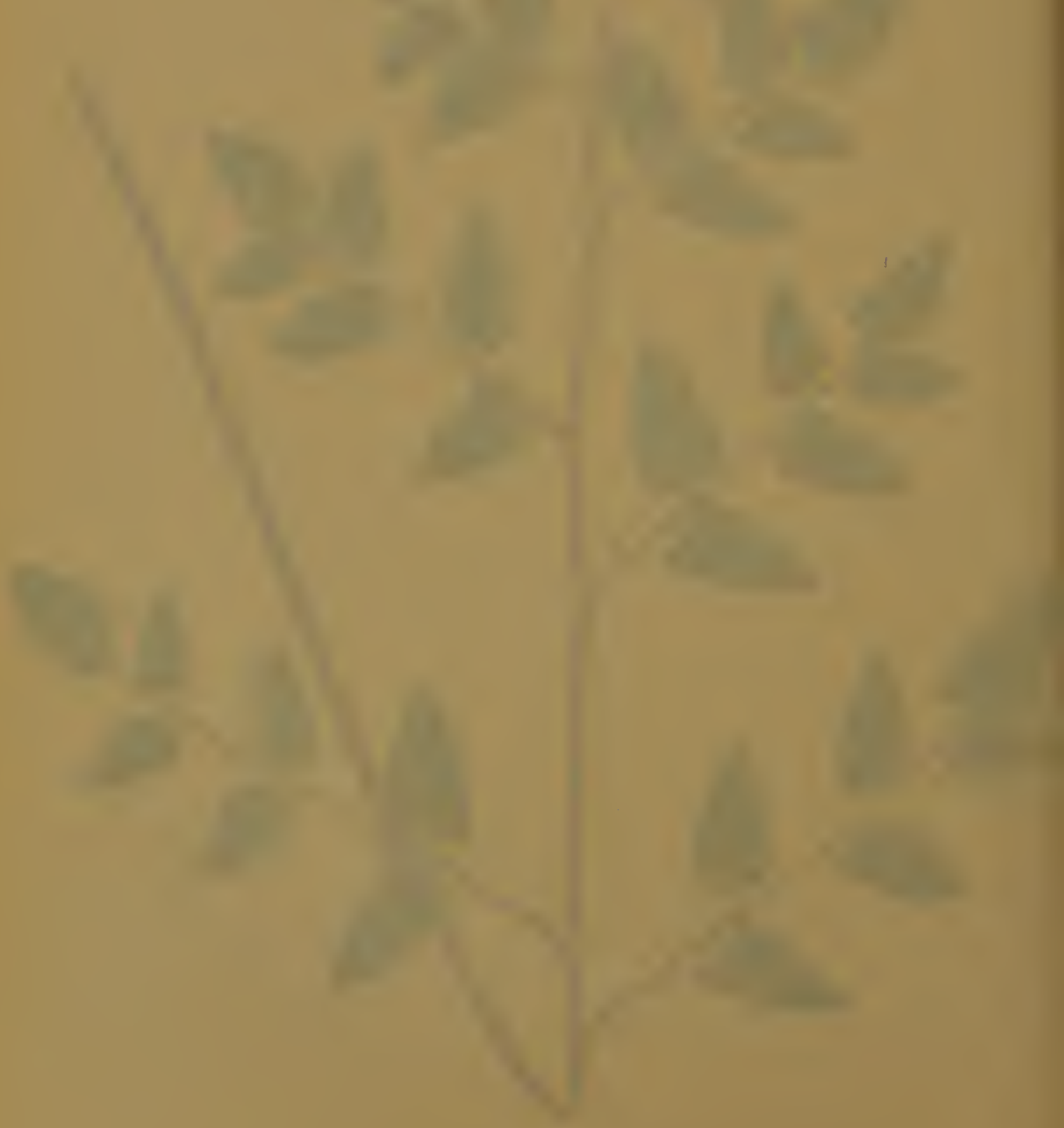




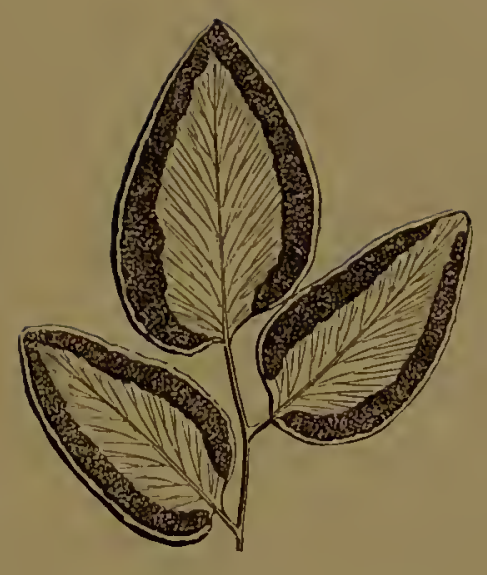

Portion of fertile Frond-under sidc.

\section{PLATYLOMA SAGITTATA.}

\section{Moore and Houlston.}

PLATE XXVIII. VOI. III.

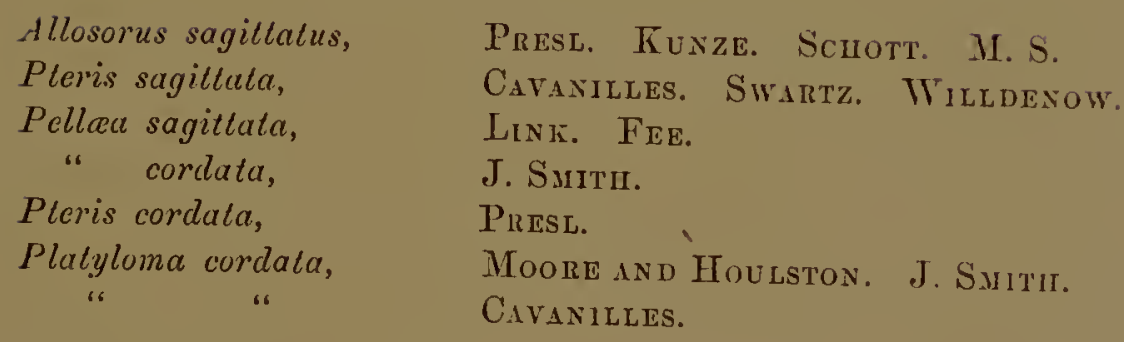

Platyloma-Broad-edge.

Sagittata-drron-shaped.

In the Section P'eliatid of Authors.

$\Lambda$ puETTY Fern, approaching nearer to Platyloma flexuosu than to any other of our cultivated species. It bears two names in gardens, namely, $P$. cordata and $P$. sayjitata. It is not a common species, only to be procured from our lirger collections. Erect in its habit. 
A somewhat deciduous, warm greenlouse Fern, from Mexico.

Raised from spores at the Royal Gardens, Kew, in the year 1842.

Fronds triangular, bipinnate; pinnules cordate-lanceolate, having the singular property of rolling the margins under, and thus becoming arrow-shaped; stalked, smooth, glaucous.

Sori linear, continuous, broad; indusium narrow.

Rachis and stipes pale brown, lateral, adherent to a brief creeping rhizoma.

Length of frond from eighteen inches to two fect; colour glaucous grcen.

My thanks are due to Mr. Sim, of Foot's Cray, for a plant of this species; and to M. Schott, Director of the Imperial Gardens at Schonbrünn, near Vicnna; Mr. J. Henderson, of Wentworth; and to Mr. Norman, of IIull, for fronds.

It is in the Fcrn Catalogues of Messrs. Sim, of Foot's Cray; Rollisson, of Tooting; Veiteh, Jun., of Chelsea; A. Henderson, of Pine-apple Place; Parker, of IIolloway; Booth, of Hamburg; Kennedy, of Covent Garden; and Stansfield and Son, of the Vale Crardens, 'Todmorden. 



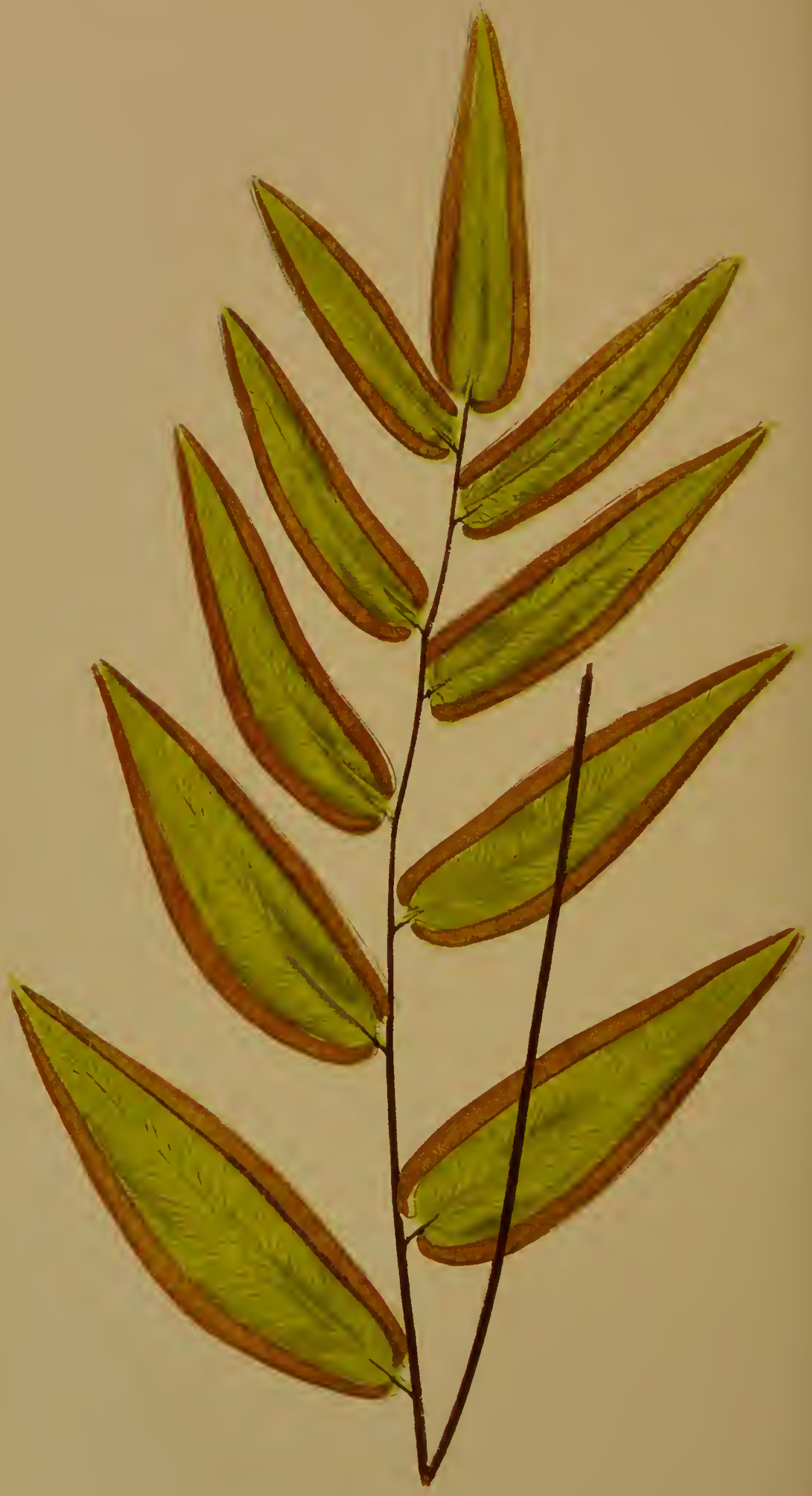

PLAIYIC MA BROWNII. 

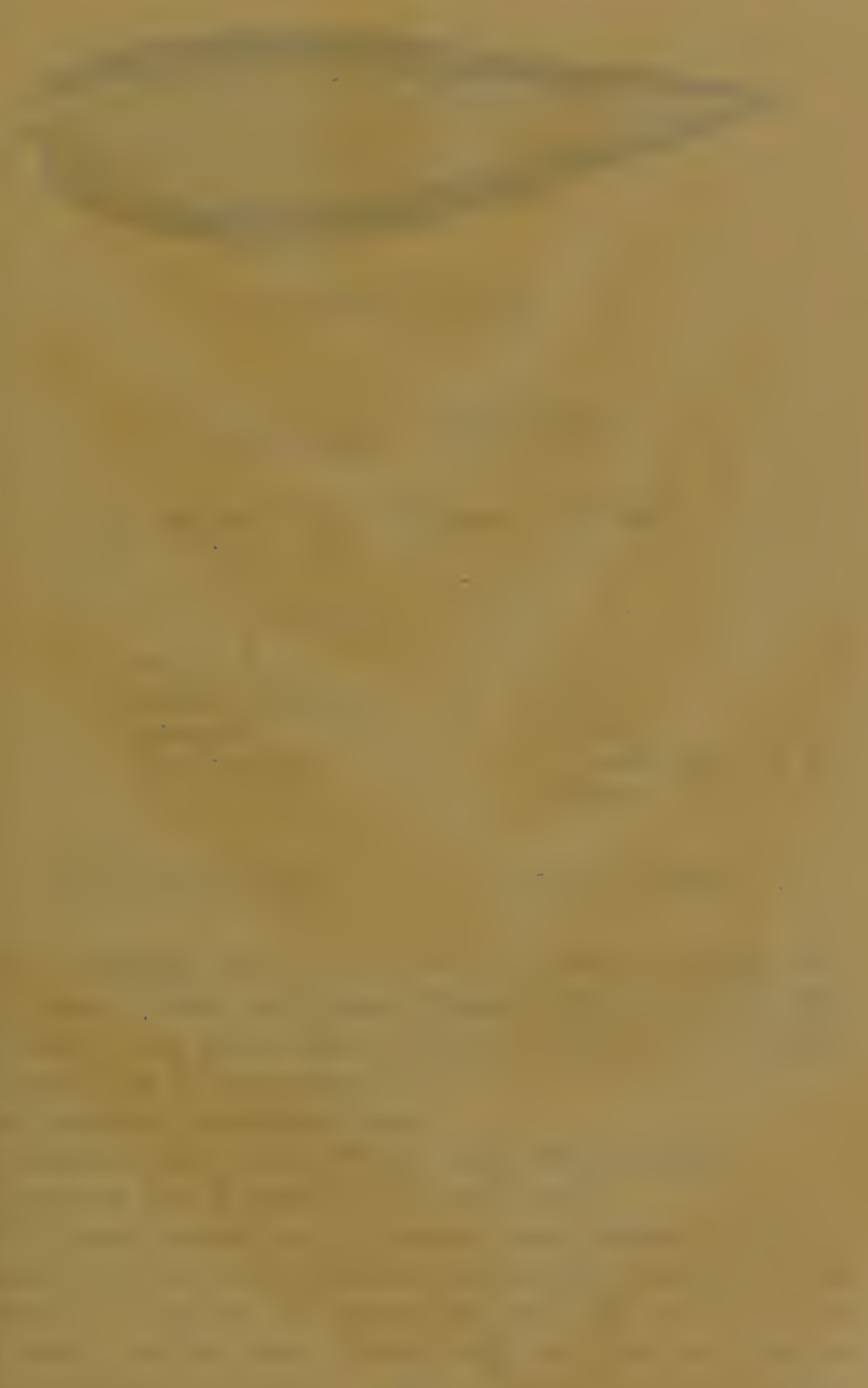


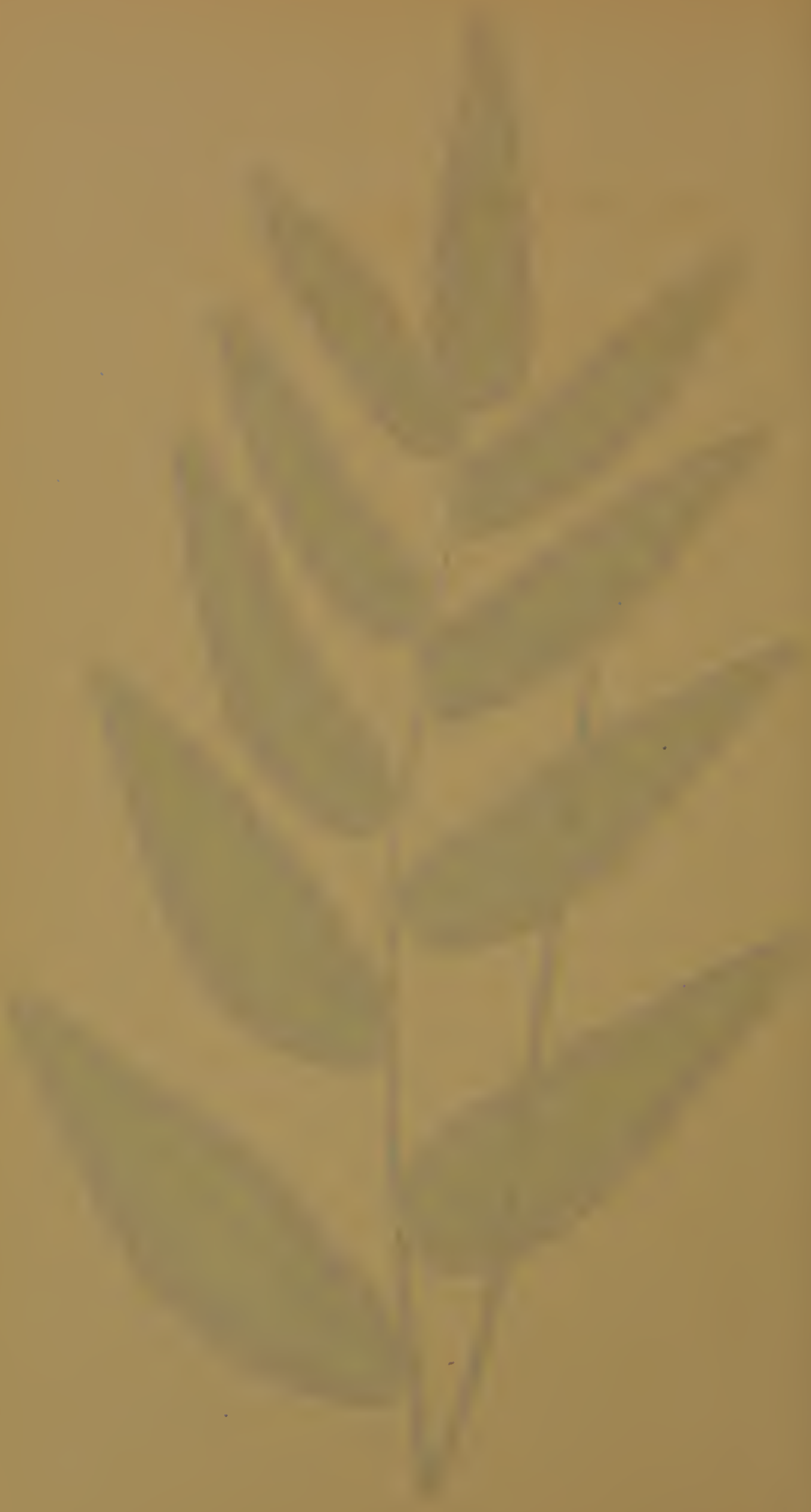


Pinna of fertile Frond-under side.

\section{PLATYLOMA BROWNII.}

\section{J. Smitil. Fee. Hooker. Moore.}

PIATE IXIX. FOI. III.

Allosorus paradoxus, Alliuntum

Pteris latizona,

" paradoxu,

Platyloma-Broad-edge.
KUNZE.

R. Brown.

A. Cunningliam. M. S. Destatx.

Brownii-Brown's.

Tine Platyloma brownii is a stout, handsomc-looking, rare l'ern, whose fertile and barren fronds contrast greatly with rach other. It is well worthy of gencral cultivation, yct sclelom to be met with in our gardens.

An crergrecn greenhousc Fern.

A native of $\mathrm{New}$ South Wales, about Moreton Bay.

Introduced into England in the ycar 1821.

'The fronds, which are coriaccous, are pimnate, with few (comparatively with $P$. falcata, its nearest ally,) pinnac, varying in number from four to eight pairs, and in sizc from an inch and a half to three inches long, and from one half to seven cighths of an inch in width. These are ncarly heartshined divisions.

'The stipes long, brown, and roundish, furnished with small hair scalcs, especially below. 
Sori continuous along the whole margins, forming a very broad band; the indusium, which is of that nature which is callecl spurious, very narrow, not covering the sporc-cases, and consisting of the revolute attenuated margin.

Length of frond from one to two fect; colour above dark grecn, below palcr. Rhizoma creeping subterraneously.

A plant of eisy culturc with ordinary managcment.

'The fronds are nearly crcct.

For a plant of this species I an indebted to Messrs. E. G. Hcnderson, of the Wellington Nursery, St. John's Wood; and for fronds to Mcssrs. Rollisson, of 'Tooting; and Mr. Joseph Henderson, of $\mathrm{W}$ cntworth; and for valuablc information regarding this Fern to Mr. Moorc, the able Curator of the Chelsea Botanic Gardcns.

It is in the Catalogucs of Messrs. Sim, of Foot's Cray; A. Hendcrson, of Pine-apple Place; Parker, of Holloway; E. G. Henderson, of St. John's Wood; Stansfield, of 'Todmorden; and Rollisson, of Tooting.

'The illustrations are from fronds off the plant in my own collection.

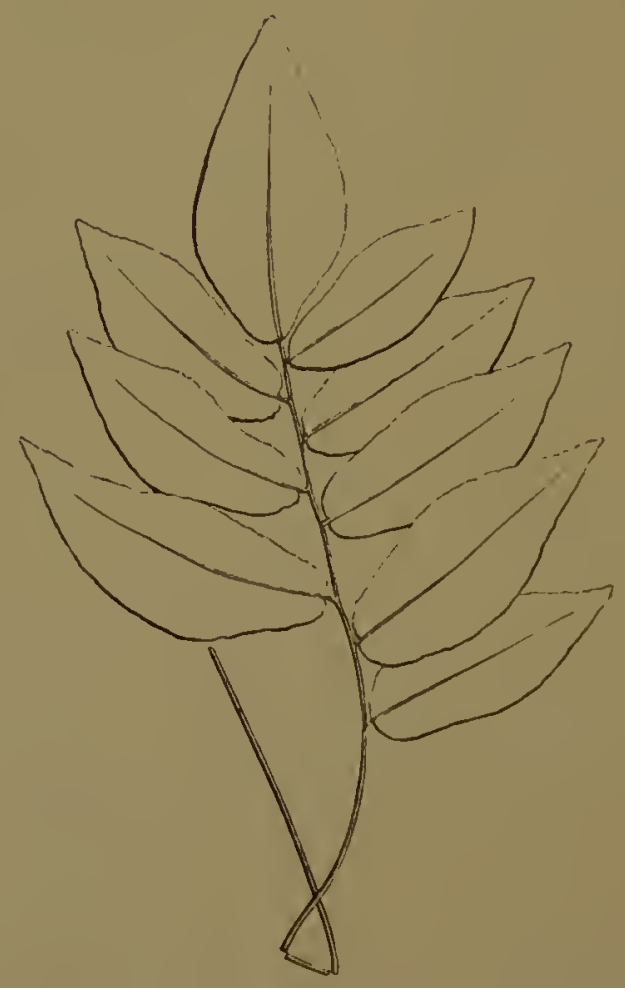

Buren lrond. 



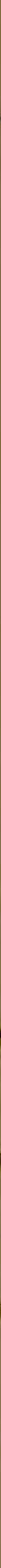




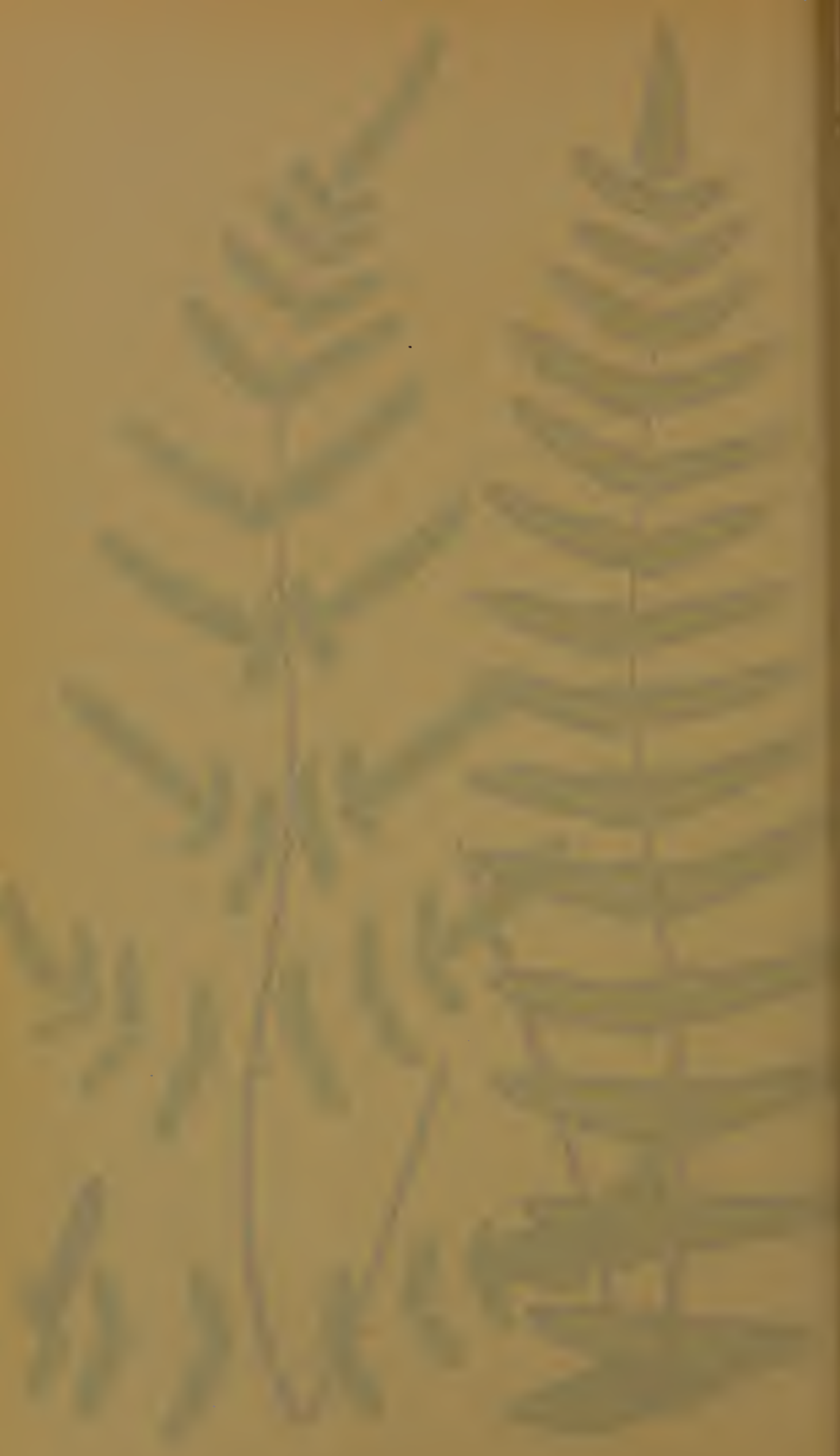




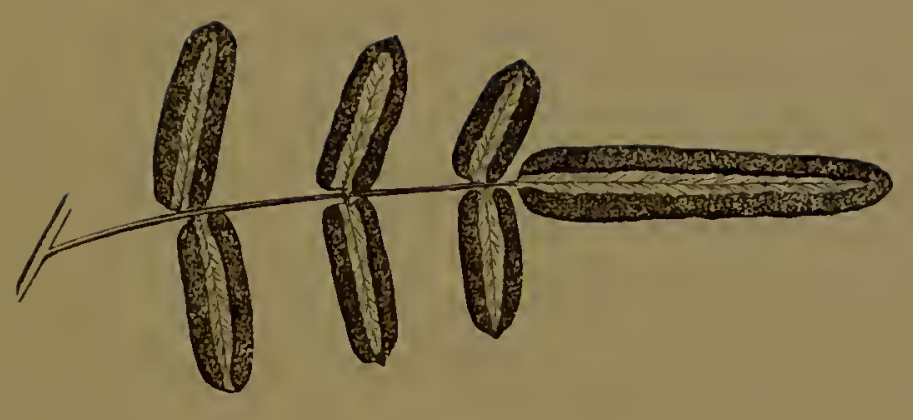

Portion of fertile Frond-under side.

\section{PLATYLOMA ATROPURPUREA.}

\section{J. Smith. Linneus. Moore and Houlston.}

PIATE XXX.-A. VOI. III.

Pellca atropurpurea, Allosorus atropurpureus, Pleris atropurpurea,

Platyloina-Broad-edge.
J. Shitif. Link. Fee. Lamarek. Kunze. Prest.

Linnaus. Hooker. Schinulr.

Arothes intercsting dwarf spccics, although it cannot be aid to vie with Platyloma ternifolia, $P$. calomelanos, or $P$. flexuosa, still all the Platylomas are handsome. It is not difficult to cultivate in a light fibrous soil, with abundance of drainage. The soil should not be kept too wet, frequent partial watcrings are bad, as the soil is by this means licpt too wct, less frequently and a copious supply is more beneficial.

An erergreen frame or greenhouse species, not sufficiently hardy to stand over winter's cold.

A native of North America.

Introduced into the Royal Gardens, Kew, in the year 1770 , yet is by no means a common Fcrn at the present day.

Form of the frond ovate-lanceolate, bipinnate, the pinnules 
being glabrous, oblong or bluntly ovate, cordate at the base; terminal pinnule elongate.

Rachis and stipes covered with hairs, terminal, adherent to a somewhat crceping rhizoma.

Sori linear, continuous, cxccedingly broad. Indusium narrow. Length of frond usually from six to ten inches; colour a heavy blue greell.

My thanks are due to Mr. Stratton, of the Cambridge Botanic Gardens, for a plant of this species; and to Mr. Henderson, of Wentworth, and to Mr. Norman, of Hull, for fronds.

It is in the Fern Catalogues of Messrs. Veitch, of Excter; Veitch, Jun., of Chelsea; A. Henderson, of Pinc-apple Place; Sim, of Foot's Cray; Booth, of Hamburg; and Kennedy, of Covent Garden.

The illustration is from a plant in my own collection. 


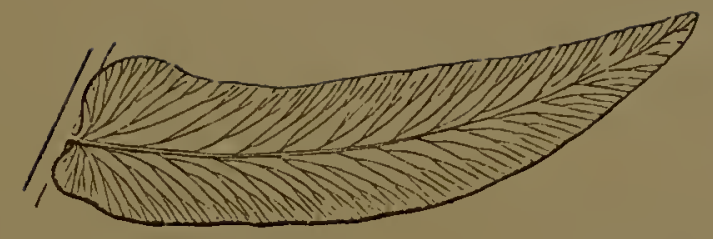

Pinna of mature Frond-npper side.

\section{PLATYLOMA FALCATA.}

\section{J. Smith. R. Brown. Moore and Hodlston.}

PLATE XXX.-B. VOI. III.

Allosorus falcatus, Pleris fulcala, Pellaca falcata,

Platyloma-Broad-edge.
Kunze. Schotт. M. S.

Brown. Link. Hooker. Prest.

FEE.

Avother handsome Platyloma, easily eultivated if the thrips can be kept from it; they appear very fond of this Fern, and soon make great ravages with its fronds, weakening the plant to a very great extent.

An evergreen grecnhouse species. Native of New Holland. Introduced into the Royal Gardens, Kew, in the year 1823, by Mr. Allan Cunningham.

The form of the frond is lanceolate, pinnate; the pinna being glabrous, linear-lanccolate, oblong, bluntly-acuminate, falcate, cordate at the base, coriaccous. Rachis and stipes squamiferous. Lateral, adherent to a crceping rhizoma.

Sori linear, continuous, extending from the base to nearly the apex of the frond, very broad. Indusium very narrow.

Length of frond from one to two feet, rather erect.

Colour of the frond abore dull green, beneath paler.

VOL. III. 
For plants of this speeies I am indebted to Mr. Pass, gardener to T. Broeklehurst, Esq., of The Fenee, near Maeelesfield; Messrs. Veiteh, of Exeter; Mr. Norman, of IIull; Mr. Ingram, of the Royal Gardens, Windsor; Messrs. E. G. Henderson, of St. John's Wood; Mr. Masters, of Canterbury; and for fronds to M. Sehott, of the Imperial Gardens, Sehonbrünn, near Vienna; Mr. Henderson, of Wentworth; Messrs. Booth, of Iamburg; and Mr. Norman, of Hull.

It is in the Cataloguess of all the prineipal Nurserymen.

\section{PLATYLOMA FALCATA, VARIETY CAUDATA.}

'I'rus Fern has a charaeter and habit midway between $P$. falcate and $P$. rotundifolic. It was scnt to me under the name of $P$. cordata, as the pinnules hare a pointed apex rising out of a rounded end; perhaps this may have been misspelt for caudata. It will therefore be retained as $P$. falcata, var. caudata. The P. corclata of gardens is figured on Plate XXVIII. The venation is bolder than in the normal form of $P$. falcata. It is doubtful whether it will ever prove to be more than a variety.

The illustration is from a plant in my own collection.

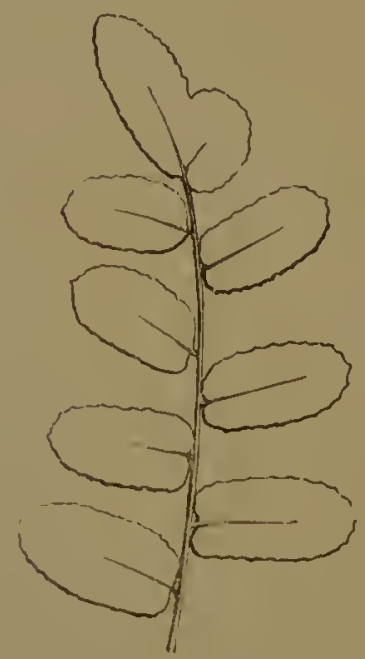

Varicty Caudnta.

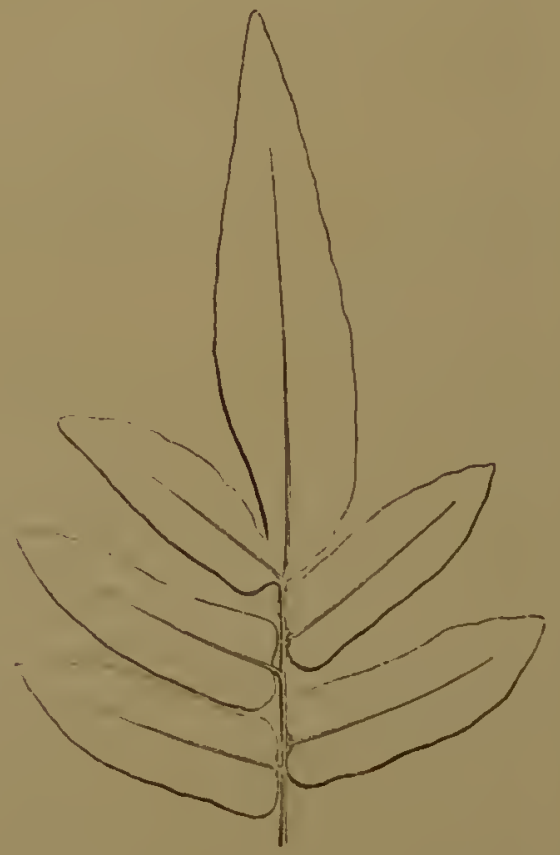

Barren Frond-Xormal form. 
. 


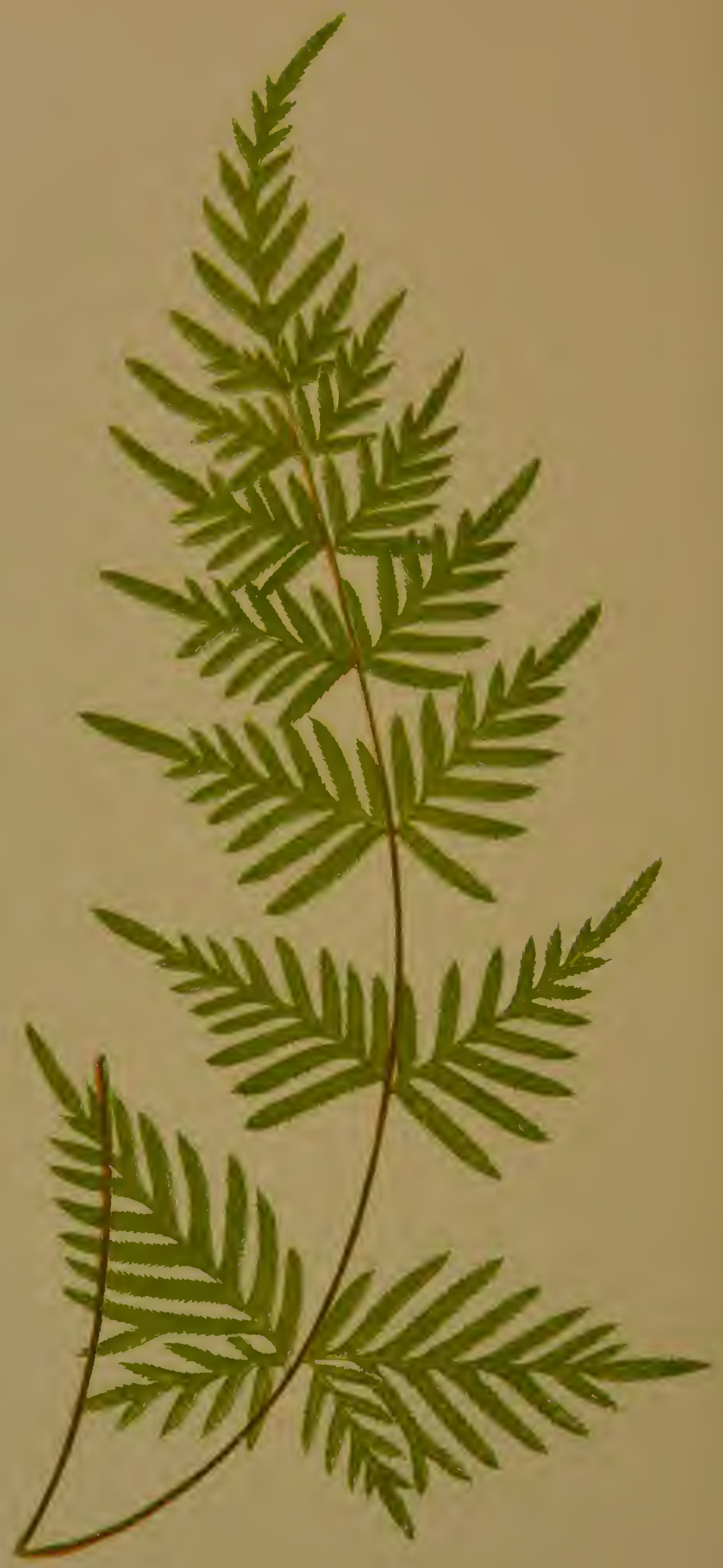




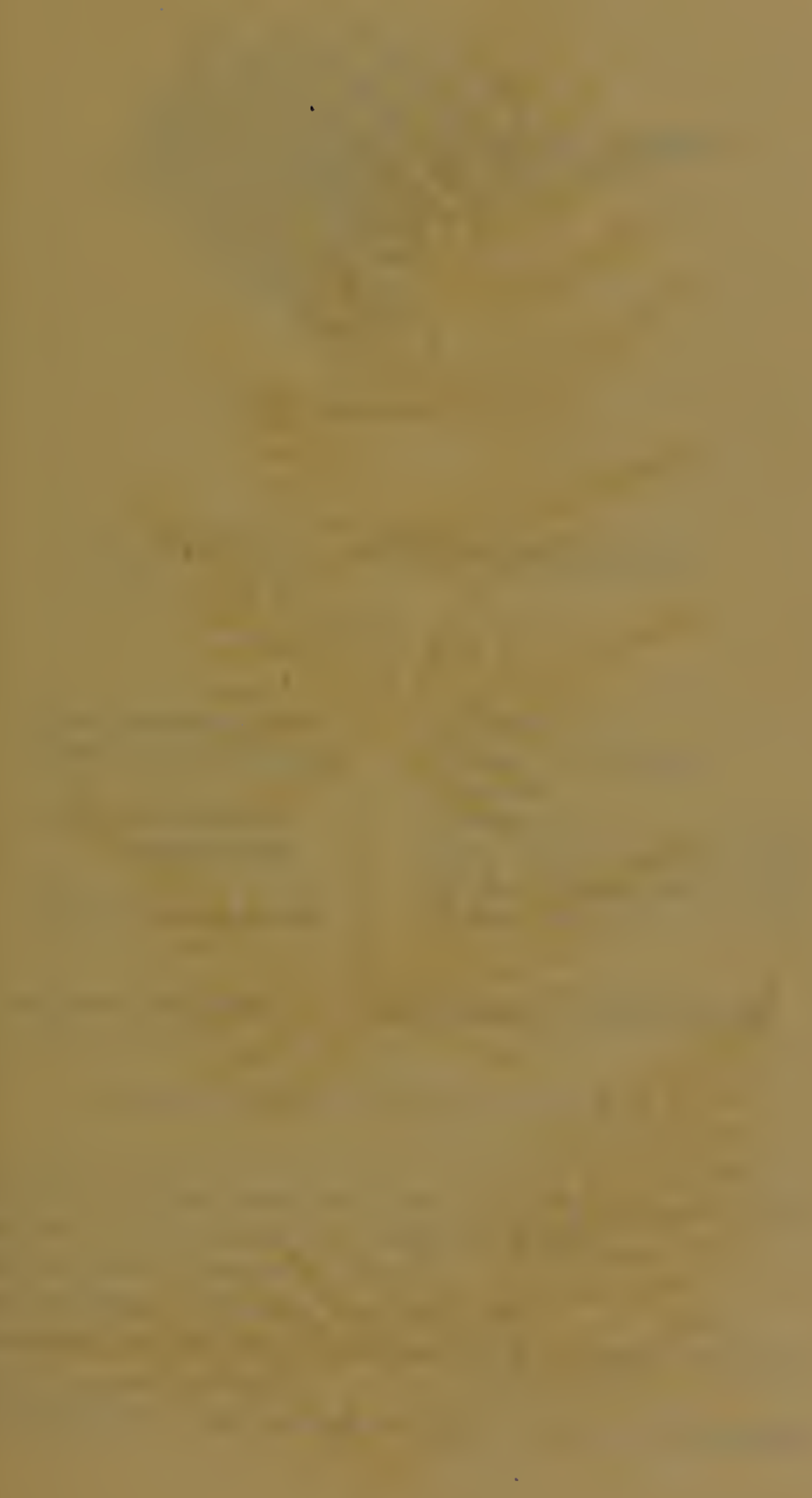




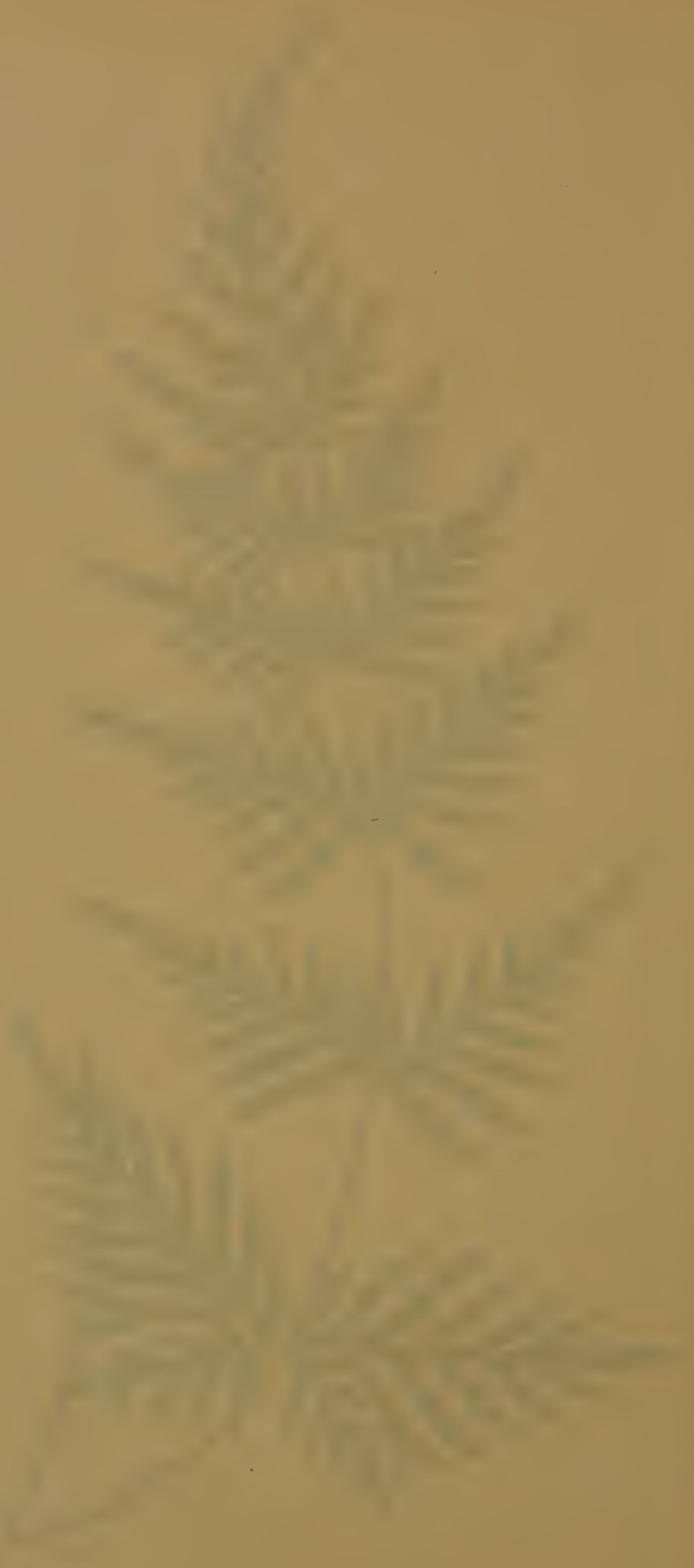




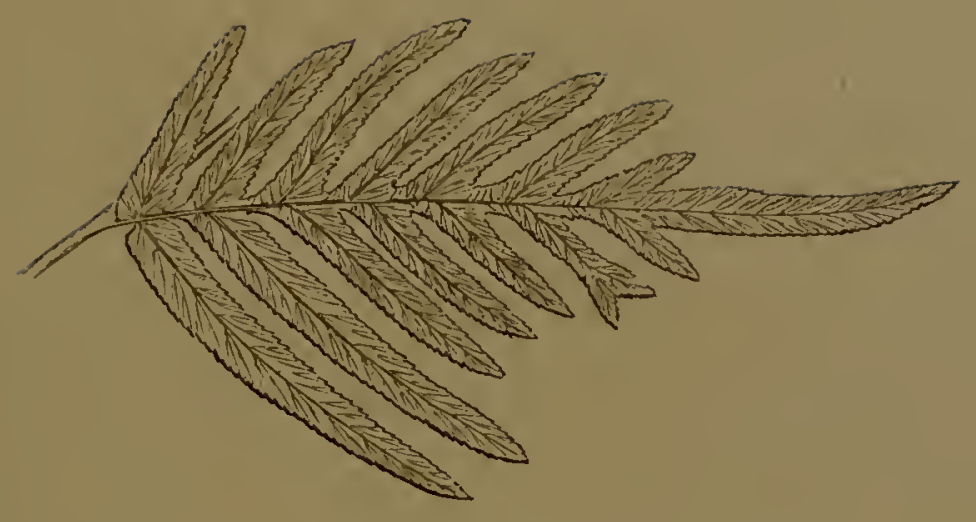

Portion of mature Frond-upper side.

\title{
PLATYLOMA INTRAMARGINALIS.
}

PLATE XXXI. FOI. III.

\author{
Pellea intramarginalis, \\ Cassebetra inframarginalis, \\ “ \\ "6 \\ Pteris inframarginalis, \\ " intramarginalis, \\ “6 \\ " \\ Allosorus intramarginalis, \\ J. SMITIr. \\ Moore and Houlston. \\ J. Sмiтh. \\ KaULFUSS. \\ Link. Kaulfuss. Schott. M.S. \\ Kunze. Schlectendal. Fee. \\ Kunze. Presl.
}

Platyloma-Broad-edge. Intramarginalis-Within-margined.

In the Sectiox l'elLeæa of Authors.

A DELICATE and uncommon Fern, requiring care, yet at the same time one deserving the necessary attention.

An evcrgreen greenhouse Fern.

An inhabitant of Mexico and Guatemala.

Received at the Royal Gardens, Kew, in 1841, from the Royal Gardens of Berlin.

'The fronds are ovate-lanceolate in form, glabrous, bipimnatifid 
and even tripinnatifid below, the segments bcing linear-aeuminate with a serrate margin.

Rachis and stipes dark brown in colour, slender, terminal, adherent to a short erecping rhizoma.

Sori lincar, eontinuous, intramarginal, consisting of a single row of sporc-eases; the indusium plane, and also linear and eontinuous.

To Mr. J. Henderson, of Wentworth, I am indebted for a plant and fronds of this species; and to M. Schott, of the Imperial Botanie Gardens, of Schonbrünn, ncar Vienna, for other fronds.

It is in the Fern Catalogues of Messrs. E. G. Henderson, of St. John's Wood; Parker, of Holloway; Kennedy, of Covent Garden; Sim, of Foot's Cray; Veiteh, Jun., of Chelsea; and Booth, of Hamburg.

The illustration is from a plant in my own collection. 



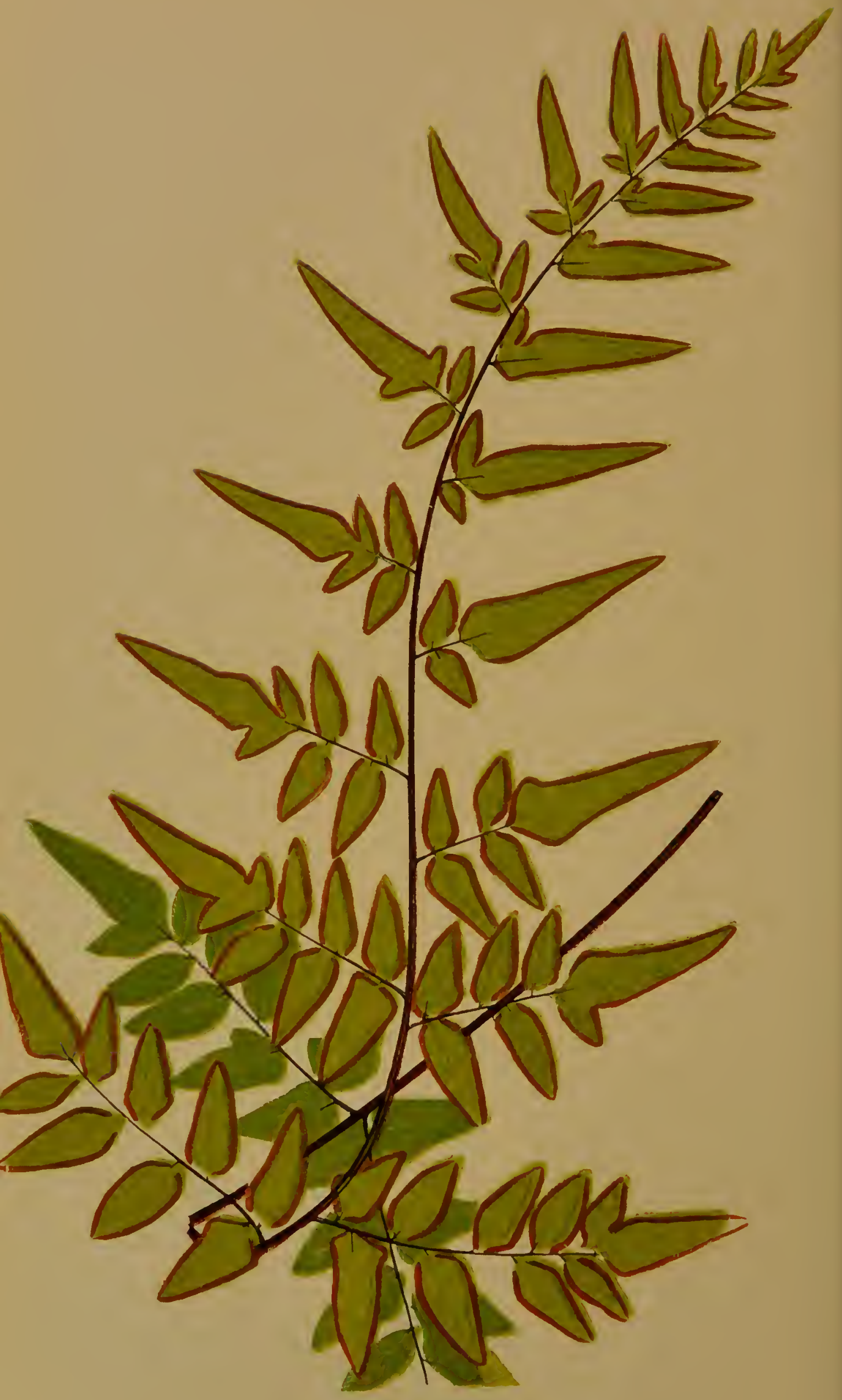




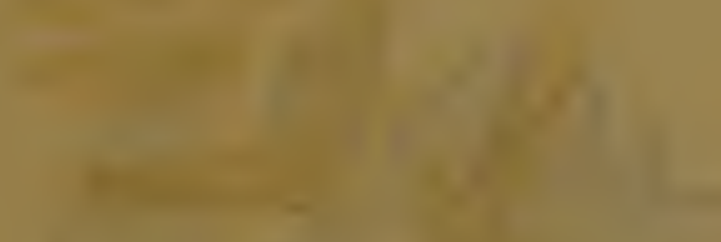

(1)

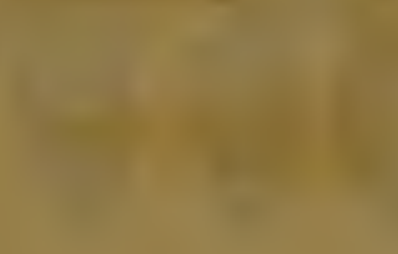

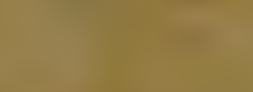

\section{$11+\ln =$}

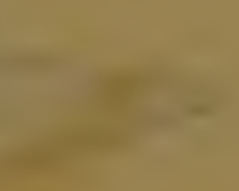

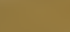
$x^{2}=$

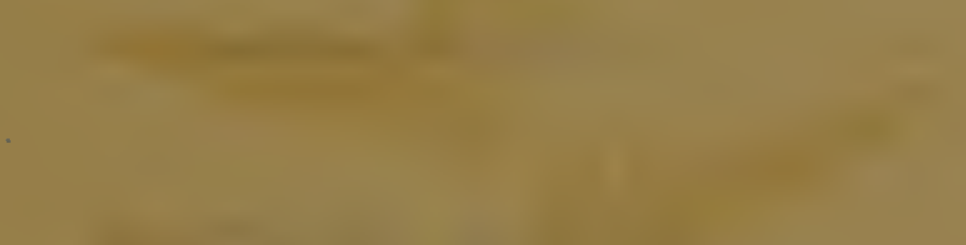

$$
x^{2}+x^{2}
$$

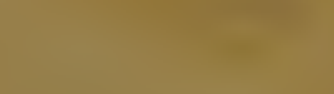

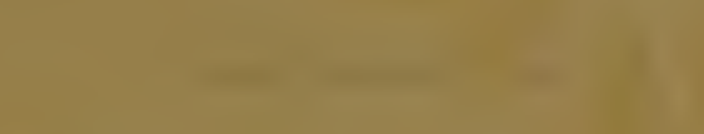

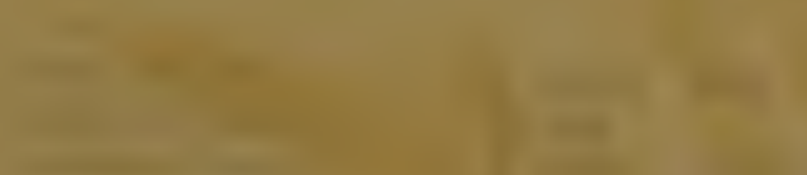

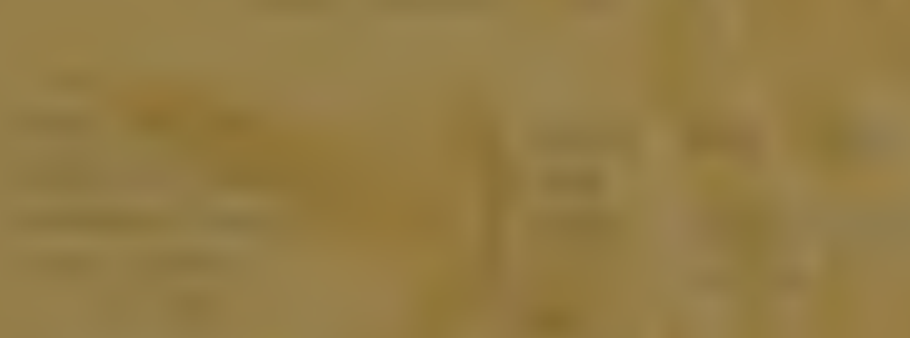

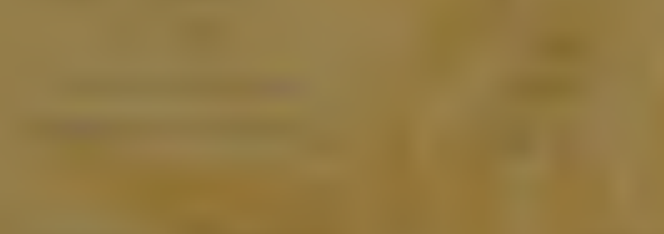

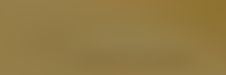

$$
-\pi
$$

15:

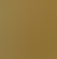

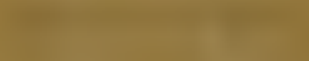
$\operatorname{lin}_{1+1}=-1$

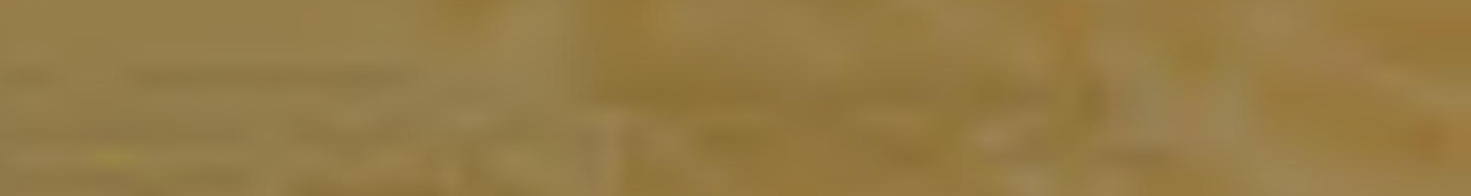

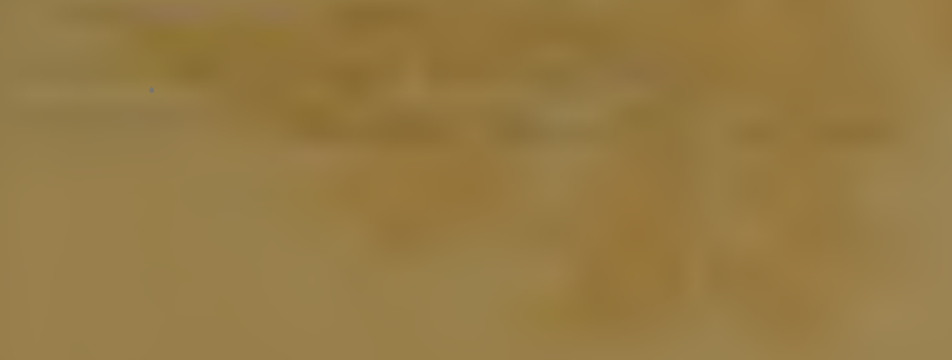




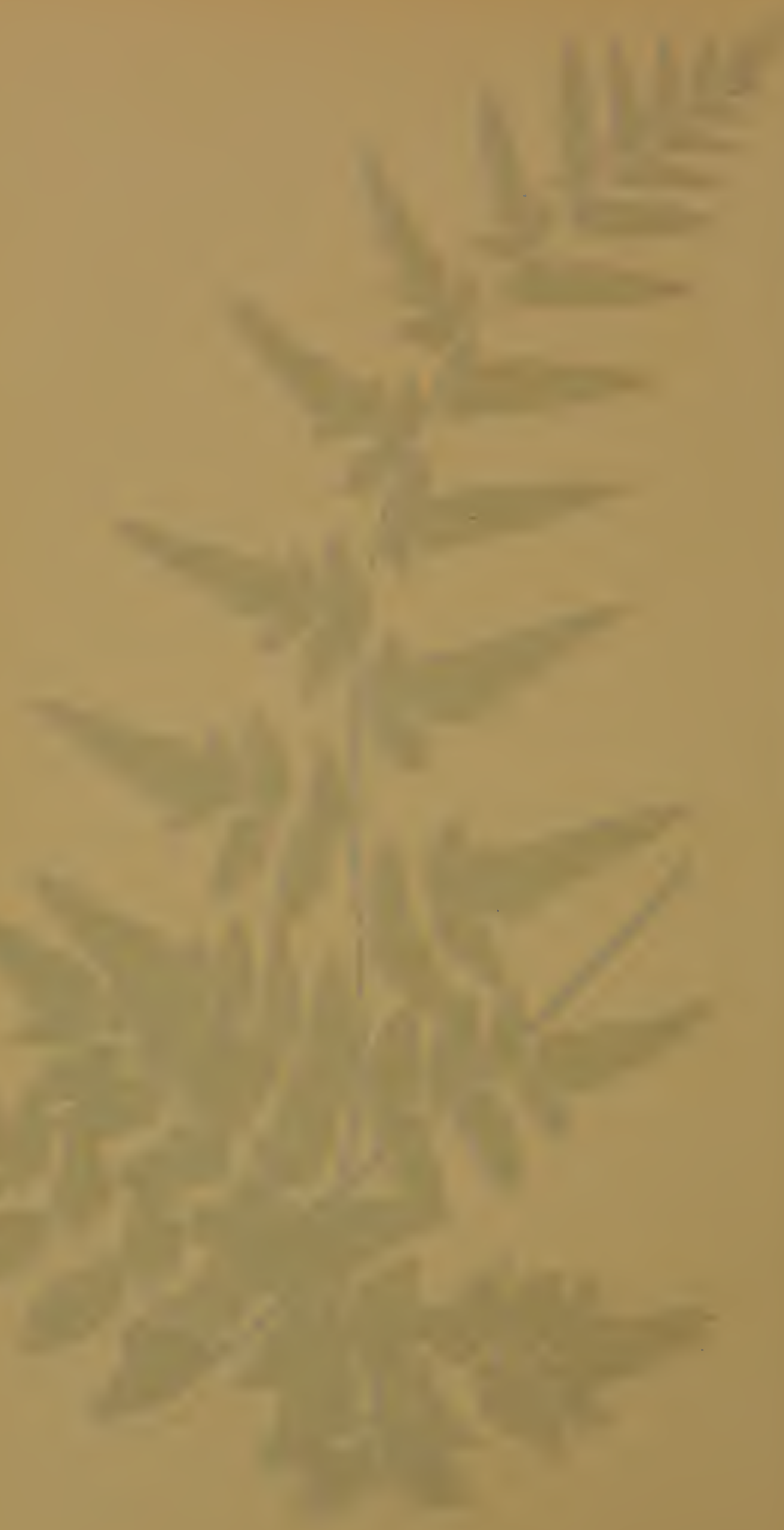




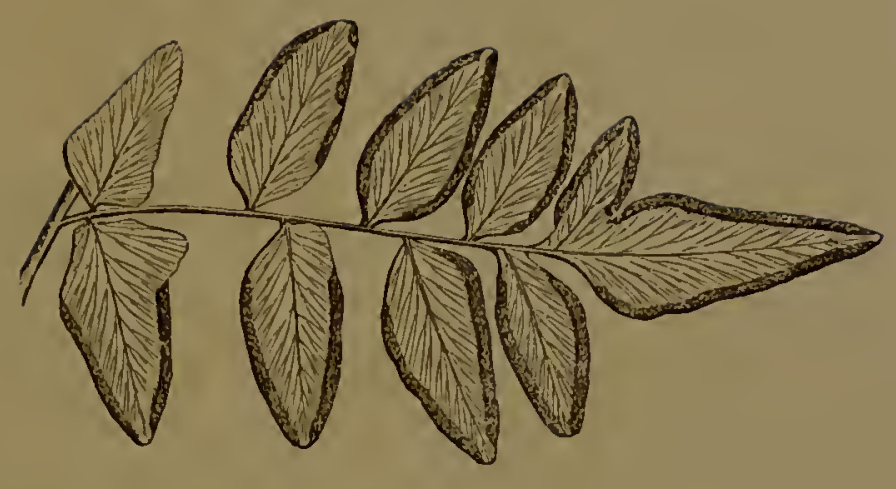

Portion of fertile Frond-under side.

\section{PLATYLOMA HASTATA.}

\section{LowE.}

PLATE XXXII. YOL. III.

Pellaca hastata, Cheilanthes hastata, Cassebeera hastata, Pteris hastata,

" viridis, Allosorus hastatus, Adiantum hastatum,

Platyloma-Broad-edge.
J. Sмith. Link. Fer. Kunze.

J. Suith. Moore and Houlston. LinnaUs. SWartz.

Forsk.

Presl.

LinNeUs.

In the Section Pellea of Authors.

THE Platyloma hastata is a pretty and not uncommon Fern, known best in the English gardens as Pteris hastata, and being easily propagated from spores.

An evergreen greenhouse species.

A native of the Cape of Good Hope.

Introduced into England before the year 1822. 
The fronds, which are glabrous, are bipinnate; the pinnw bcing eordate, hastatc; margin crenatc.

Rachis and stipes terminal, dark brown, adherent to a short creeping rhizoma.

Sori linear, continuous; indusium planc.

Length of frond from twelve to eighteen inches; colour ycllowish green.

My thanks are duc to Mr. Henderson, of Wentworth, for a plant of this species; and to Mr. Norman, of Hull, and MIcssrs. Booth, of Hamburg, for fronds.

It is in the Fern Catalogues of Messrs. Booth, of Hamburg; E. G. Henderson, of St. John's Wood; Bass and Brown, of Sudbury; Osborn, of Fulham; Veitch, of Excter; Sim, of Foot's Cray; Vcitch, Jun., of Chclsca; Masters, of Cantcrbury; Rollisson, of Tooting; Parkcr, of Holloway; Cooling, of Derby; and Stansfield and Son, of Todmorden.

The illustration is from a plant in my own collection. 



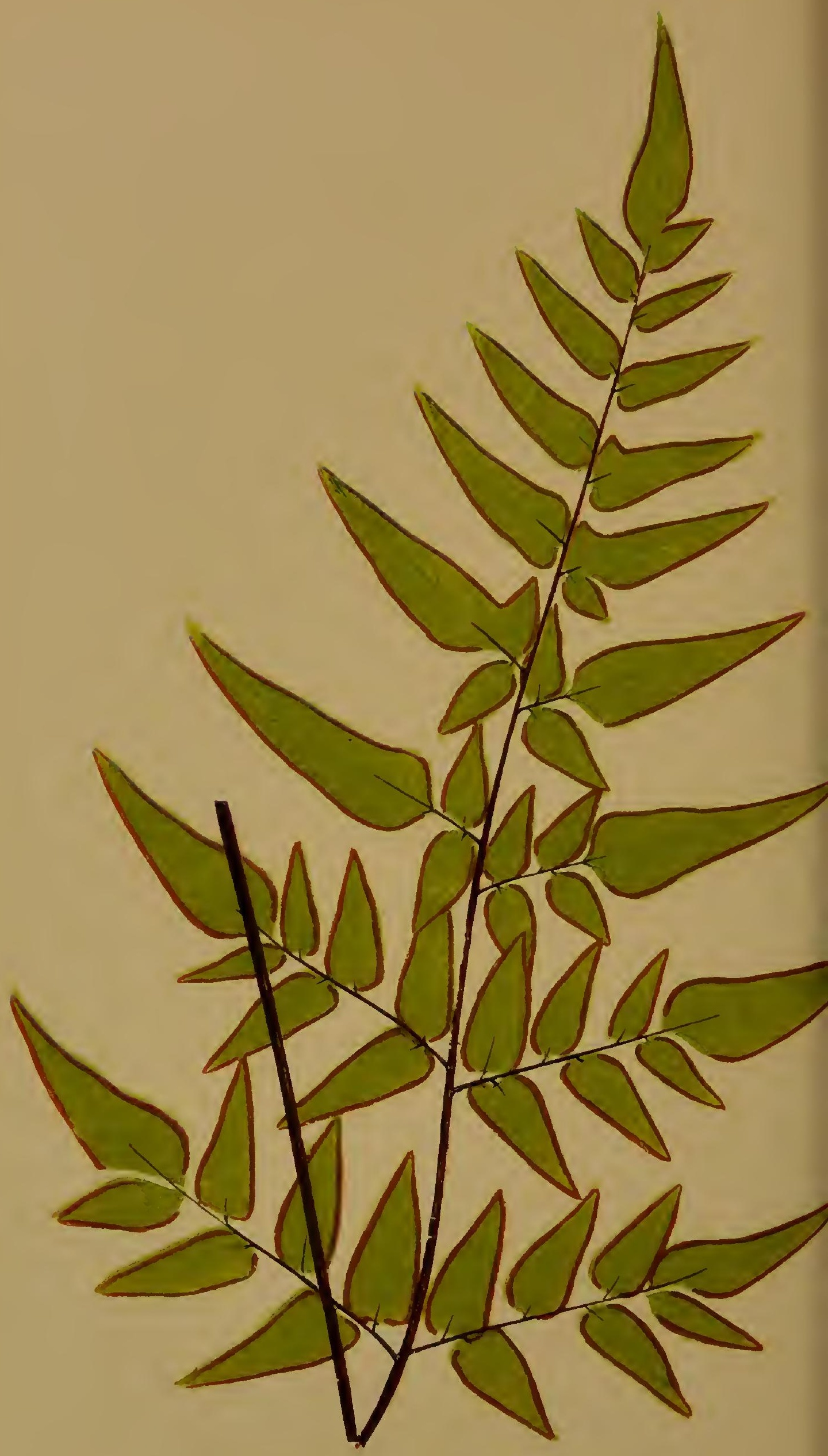





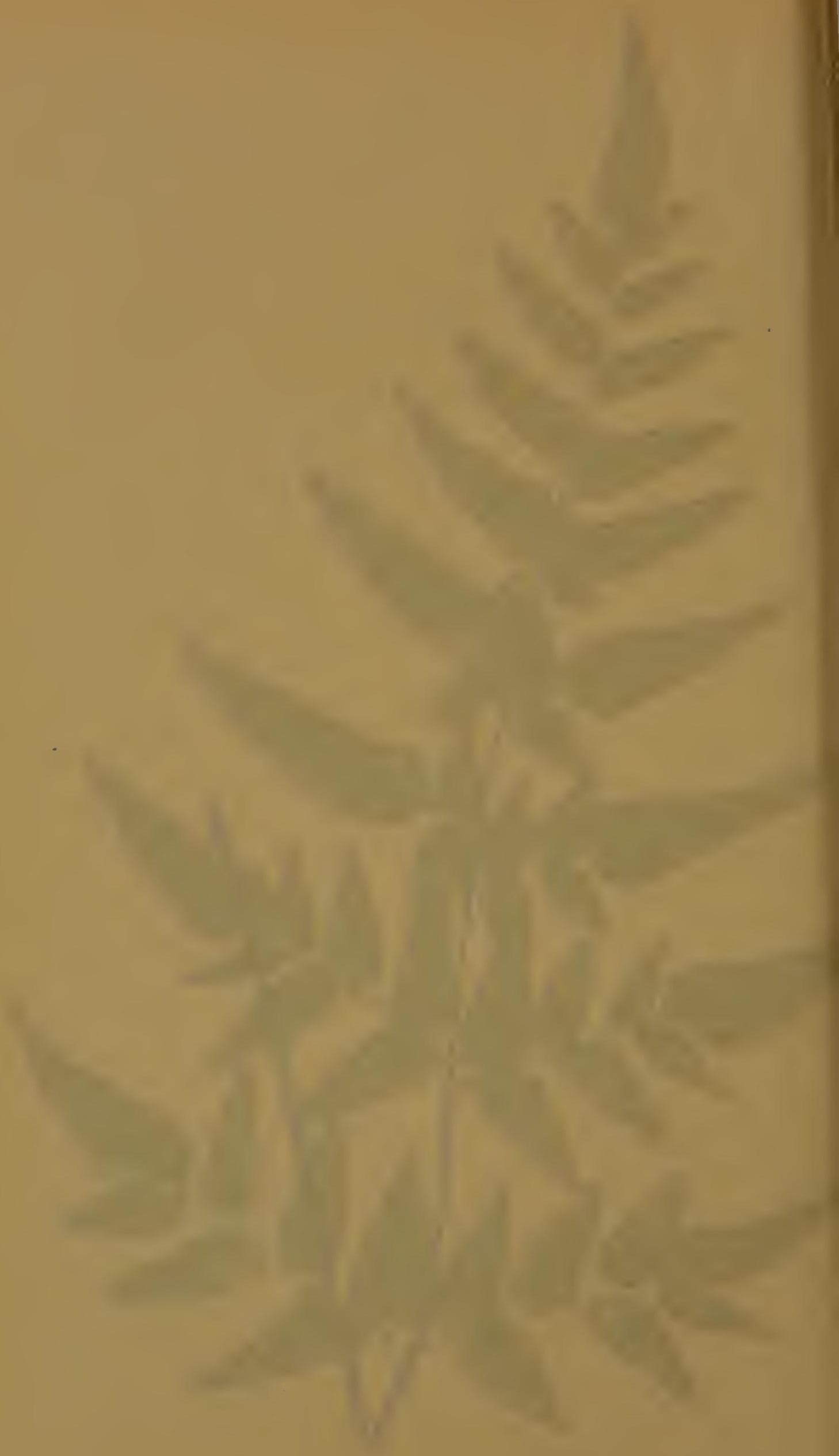




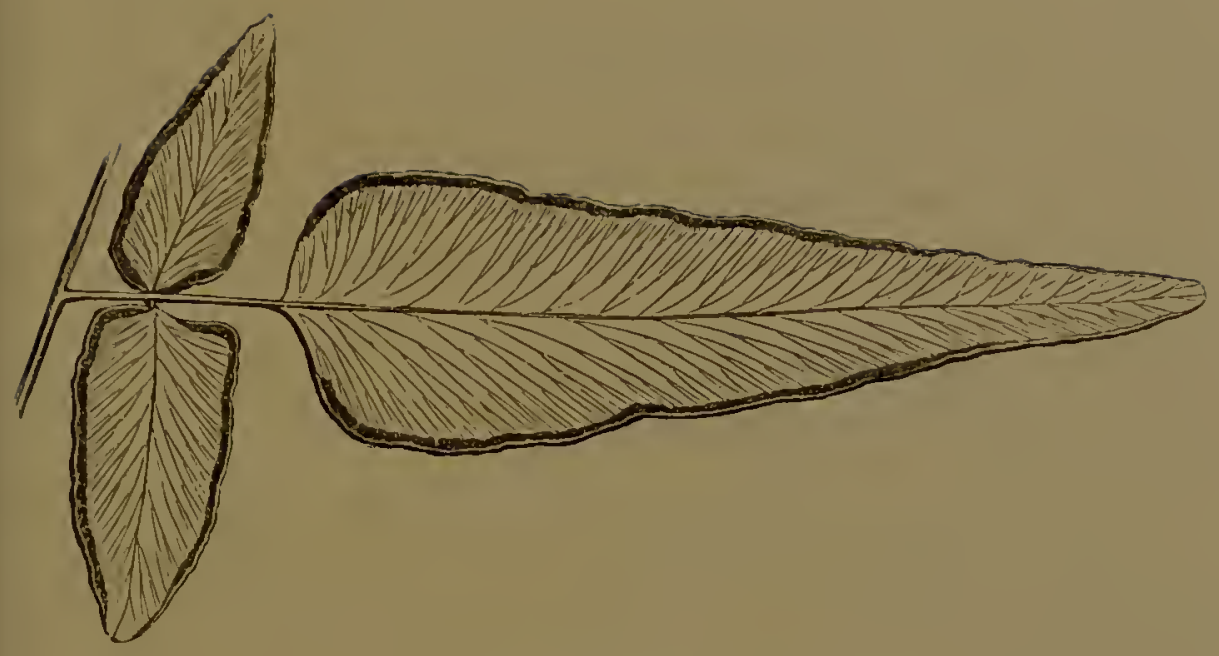

Portion of fertile Frond-under side.

\title{
PLATYLOMA ADIANTOIDES.
}

\section{LoWE.}

\author{
PIATE IXXII. YOJ. III.
}

\author{
Pellaca adiantoides, \\ Allosorus adiantoides, \\ Pteris adiantoides, \\ " latifoliu, \\ " macrophylla,
}

Platyloma-Broad-edge.
J. SMITH.

Prest.

BORY.

OF GARDENS.

KUNZE.

Platyloma adiantoides is a handsome, vigorous-growing Fcrn, resembling a large $P$. hastata. It is not commonly to be met witll, excepting in our larger British collections.

A warm greenhouse evergreen species.

Native of the West Indies.

'The form of the frond is broadly-ovate, bipinnate. 'The lowest pinnac having from seven to eleven pinnules, the rest gradually decreasing upwards to a simply pinnated apex. 
The barren frond has ovate pinnules, which are obtusely toothed, whilst those of the fertile frond are more entire and acuminate. The pinnules next to the rachis oceasionally auricled at the base, the terminal generally sub-hastate.

Sori linear, continuous.

Length of frond from eighteen inehes to two fect; colour deep green.

Pinnules subpetiolate. Stipes black and glabrous.

The Platyloma adiantoides is better known as the Pteris adiantoides and $P$. latifolia of gardens.

It differs from $P$. hastata, in being larger; broadly ovate in form instead of narrow-lanceolate as in P. hastata. It also differs in the form of the pinnules, being ovate or obtuse lanceolate, rarely hastate or crenulate.

My thanks are due to Mr. Joseph Henderson, of Wentworth, for a plant and fronds of this species, and for information regarding this Fern.

It is in the Catalogues of Messrs. Stansfield, of Todmorden; E. G. Inenderson, of St. John's Wood; and Sim, of Foot's Cray. The illustration is frond a frond sent by Mr. Henderson, of Wentworth.

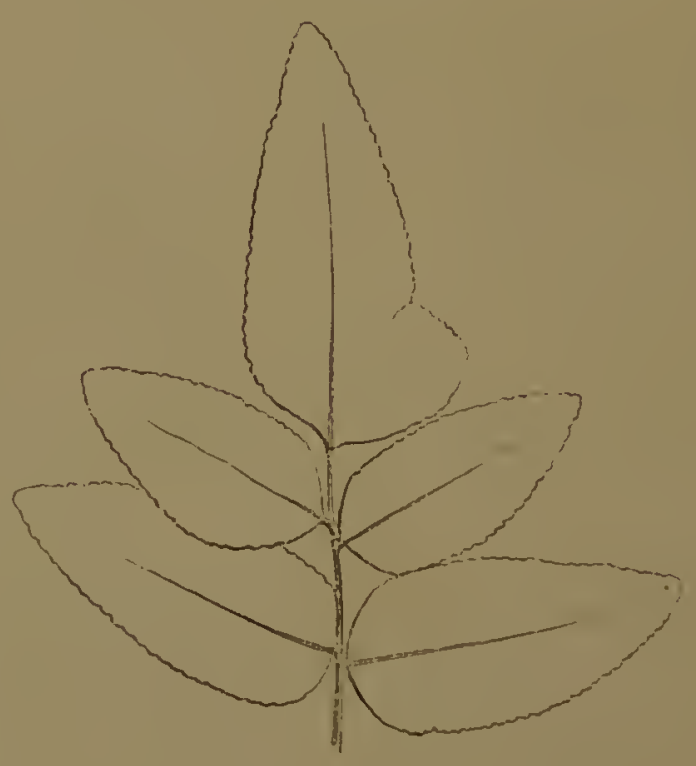

Portion of Barren Frond. 


\section{GENUS IV.}

ALLOSORUS. Beranhardi. J. SMITH.

A sMiLr genus and yet an interesting one, having barren and fertile fronds dissimilar. The fertile fronds bcing contracted and having revolute margins, forming, as it were, a universal indusium.

Teins free and forked; sporangia terminal.

Sori latcrally confluent, round or oval; the sori crentually forming an intramiarginal, broad, compound, transverse sorus.

Fronds bitripinnate, or dccompound.

Rhizoma crecping and somewhat coespitose.

- Fertile fronds contracted, scgments oval, clliptical, and revolute.

Sterile frond having the pinnules dentate, crenate, or laciniatc.

Mr. Moore places the Allosorus amongst the Polypodia, and certainly it scems nore natural than with Pteris, although it is, perhaps, a genus whose characters arc midway betwecn them, and conscquently difficult to determinc to which to attach it.

Mr. Snith remarks in his "Gencra of Fcrns," that having the margin of the fronds membranaceous and indusiiform, the sori being conflucnt, and forming, as it were, a transverse marginal sorus, it, on this account, approaches ncar to the genus Pteris; but as the indusiiform margin is formed by the changed state of the fertilc frond, and does not rise from a sporangifcrous receptacle, as in the true Pteridia, it, on this account, approaches Polypodium, from which its great difference is the contracted character of the fertile fronds.

Mr. Smith cnumerates six spccies:-

1.-Crispus, Bcrnhardi.

2.-Acrostichoides, Sprengel.

3.-Brunonianus, (Cryptogramma, Wallich).

4.-Gracitis, J. Smith, (Cheilanthes, Kanlfuss.)

5.-Ciliatus, Presl.

6.-Hirsutus, J'resl.

None scem to be cultivated in this country cxcept the solitary indigenous species, the Allosorus crispus. VOL. III. 




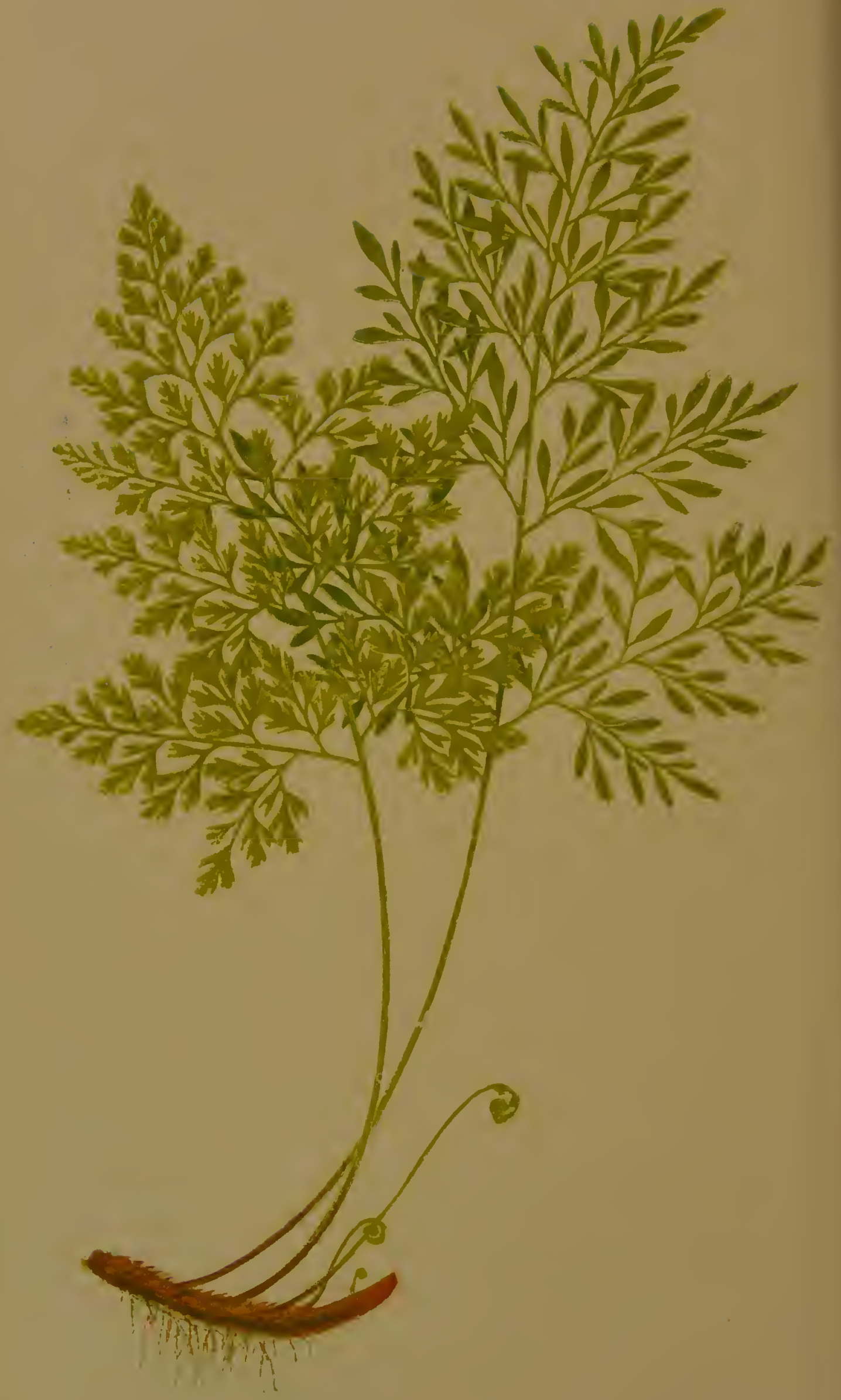





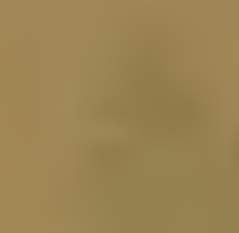

i.

$7=\frac{1}{2}$

$21,5=$

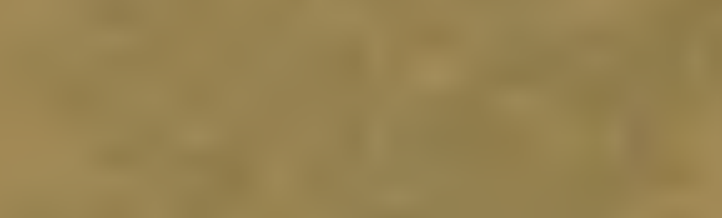

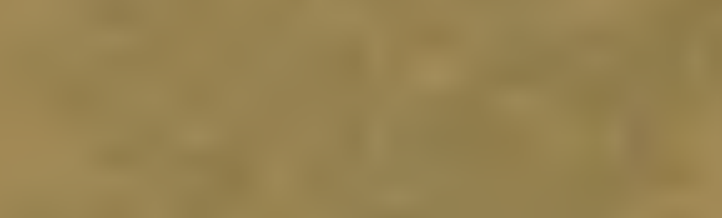

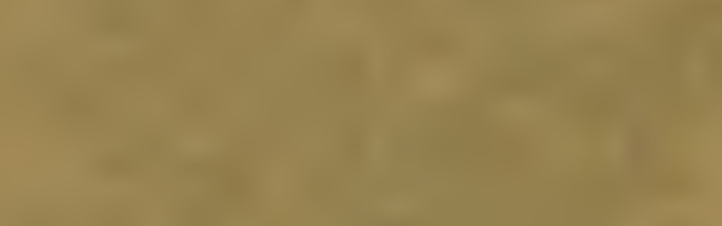
a.te

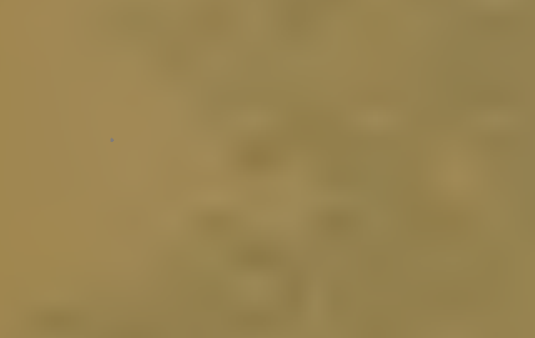

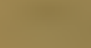
a

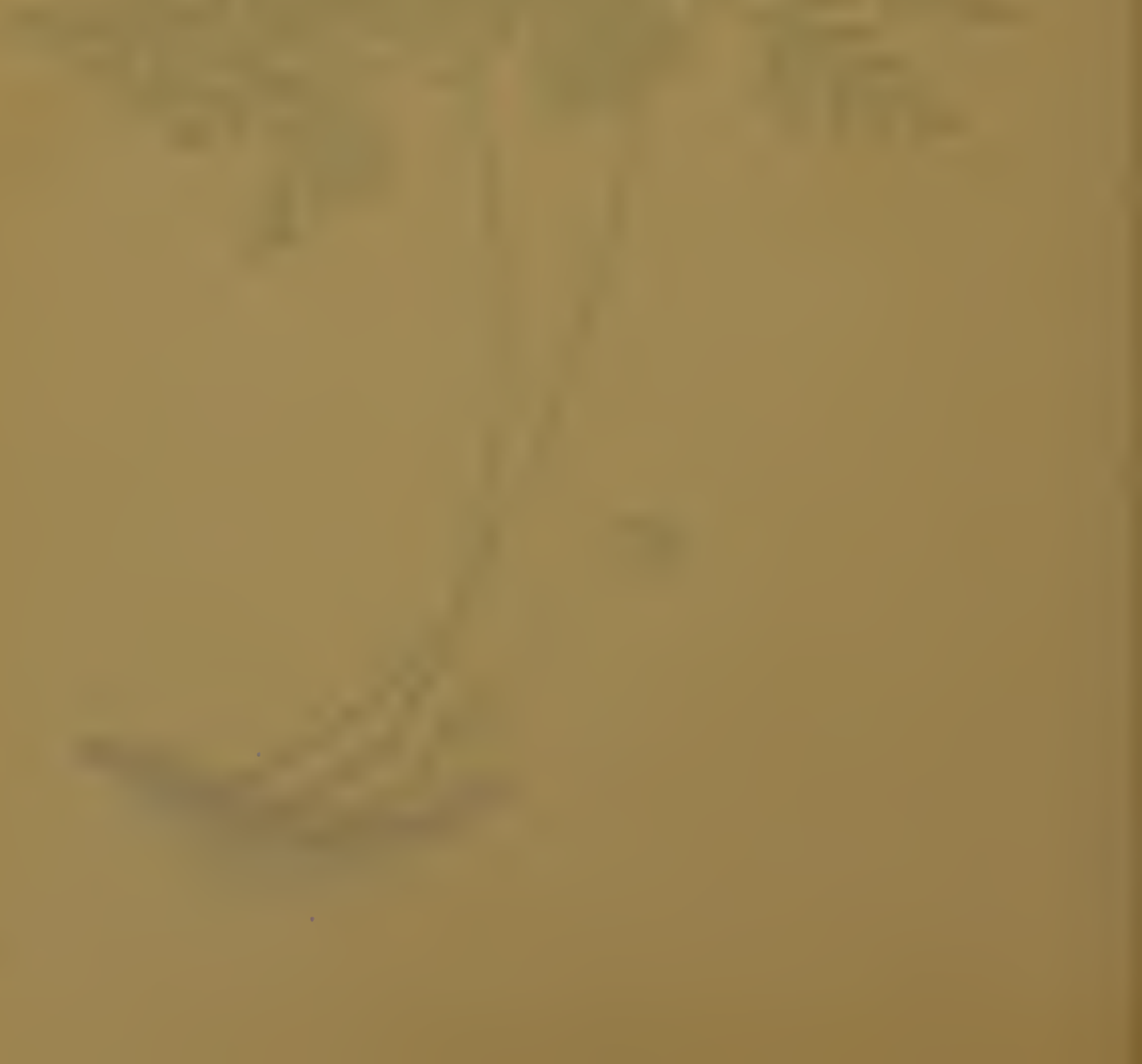




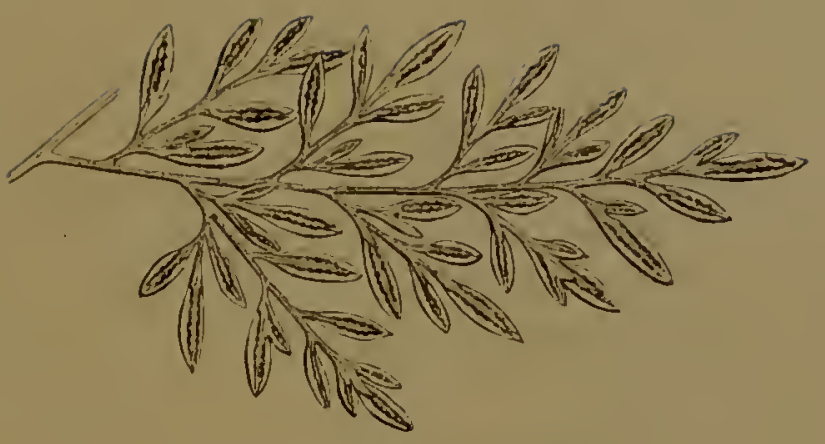

Portion of fertile lrond-under sidle.

\section{ALLOSORUS CRISPUS.}

Bernhiardi. Schrader. Babington. Deakin. Newhan. Moore. Sowerby. Sprengel. Presl. Link. Kunze. Kaulfuss. MoOre and Houlston.

PIATE XXXIT. TOI. III.

Allosorus stelleri,

Osmunda crispa,

"rupcstris,

Pteris crispa,

" stcllori,

" tenuifolia,

Acrostichum crispum,

Onoclea crispa,

Cryptogramma crispa, "

Phorolobus crispus, Stegania onocleoides,
RUPFRECHT.

LinNæus. Bolton.

SALISBURY.

LinNeus. Suitir. SCHKunr.

Willdenow.

GMeLin.

LAMARCK.

Viluars.

Hoffuann.

R. Brown. Hooker and ARnott. MaCkay. J. SMitil.

Desvaux. Fee.

Grax.

Allosorus-Diverse heaps.

Crispus-Curled.

'I're "Mountain Parslcy Fern," or "Rock Brakes," as this intercsting British species is popularly called, when well grown, 
is very handsome, the barren and fertile fronds contristing greatly with each other.

A liardy, deciduous, indigenous species.

A local yet abundant Fern on the Scotch mountains; and hills in the North of England. In Ireland it is rare, and only occurs in Antrim, Down, and Louth. In North Wales, according to Mr. Moore, it is not found below an elevation of four hundred and fifty feet, and in Scotland it ascends to three thousand four hundred and fifty feet. In Lancashirc, it descends to mearly the sea lcvel.

It is widely spread through Europe, oecurring in Lapland, Norway, Sweden, Denmark, Germany, Hungary, Switzerland, France, Spain, Italy, Sitka, England, Scotland, Ireland, and Wales.

'The Allosorus crispus does not succeed well unless it is allowed abundance of drainage, as an excess of moisture is almost certain destruction.

Sterile fronds leafy, generally about equal in length with the stipes, smooth, bipinnate, and sometimes tripimnate; pimme triangular-ovate in form, altermate, smaller as the apex of the frond is approached; pinnules also alternate, ovate in form, pinnate or pinnatifid, the lobes cut into lincar acute teeth.

Fertile fronds contracted, mostly only half as long as the stipes, tripinnate, and occasionally quadripinnate in the lower portion of the lowest pinna; pinnx altcrnate, ovate in form. pinnules alternate, pinnate above, pinnato-pinnatificl in the lowest pinna. 'The ultimate divisions are lincar-oblong, obtusc, and petiolate. Venation of the barren frond cxtending in a thin vein along each pinnule, and branching off into each lobe; it is simple except where the segment is bificl, then forked. In the fertile fronds the vein runs in al sinuous course to the apex of cach ultimate division; usually simple, occasionally forked, extending almost to the margin, and bearing a sorus near to the extremity.

The fructification generally occupring the whole under surface of the frond; sori small and rounded, approximatc, and ultimatcly confluent, thus forming a continuous line.

'Ihe margin of the pinnulets, though unaltered in texture, are incurved over the sori. 'There is no inclusium: spore-caren stalked; spores smooth, roundish oblong. 
Fronds annual, appoaring in May, and perishing carly in the autumm.

l.cigth of frond from four to twelve inches; colour lively green. Barren and fertile fronds dissimilar.

Stipes mostly longer than the frond, smooth, slcnder, and vivid green in colour. Rachis smooth; caudex small, short, tufted, and scaly. Fibres branched, wiry, and dirk brown in colour.

It delights to grow in a shady situation, frec from stagriant moisture; the latter in winter, when the fronds have disappeared, is sure to lill it.

It does not sccm subject to variety like many of our British specics.

For plants of $A$. crispus I am indebted to Miss Barker, Trent Lock, Becston; Mr. Wraight, of Newlands; Mr. Joscph Sidebotham, of Manchester; Mr. Bookcr, of Matlock; to Mr. Robcrt Clarke, gardener at Flass House, Crosby Ravensworth; and to Captain A.S. H. Lowe, for plints gathered wild in Westmorcland, For fronds, I am indebted to Mr. Giray, of St. 'Thomas', Excter; and to Mr. Norman, of Hull.

'lhe illustration is from a frond forwarded by Mr. (iray. 



\section{GENUS V.}

\section{DOR IOP'LERIS. J. SHITH.}

A churming little genus, in which are ineluded, aceording to Fee in his "Genres de la Famille des Polypodiacèes," the following:-

1.-Wullichii, J. Smith.

2.-Sugittafoliu, J. Smith, (Pteris of Raddi.)

3.-Hustata, J. Smith, (Pteris of Raddi.)

4.-Pedata, Fee, (Pteris of Linnaus, Litobrochica of Presl, Pteris pulmata of Willdenow and Plumier, and Pteris perdata of Willdenow and Plumier.)

5.-Trifoliata, Fec, (Pteris of Bory.)

6.-Raddianu, Fce, (Pteris pedutu, var., Raddi.)

T-Praculta, Fee.

8.-Articulata, Fec, (Pteris of Kaulfuss.)

Of these only four appear to be cultivated in Great Britain, and eacl is as handsome as it is possible for a Fern to be; in short, they are little gems.

Mr. Smith, in his "Genera of Ferns," gives the following:1.-Ségittifoliu, Raddi.

2.-Hustutu, Raddi.

3.-Pulmatu, Willdonow.

t.- Irullichii, J. Snith.

j.-I Iriuns, Raddi.

6.-Collinu, Raddli.

7.-Cordifolic, J. Smitlı.

Of these Nos. 1, 3, and 6 were in cultivation in Gireat Britain, howerer in Mr. Smith's new Catalogne of the Ferns in the Royal Gardens, Kew, he has now excluded $D$. collina.

A Fern which I have latcly received from the continent, under the name of Anemia fraxinifolia, will, I have rery little hesitation in saying, tum out to be the Doryopteris collina; it differs considcrably from $D$. pedatu; in the former the fronds are palmute, whilst in the latter they are digitutely palmate.

'The fronds are either simple, cordate, lobed, or digitately palmate, glabrous and coriaceous. Stipes and costa ebeneous. VOL. III. 
Length of frond from eight to twclve inches.

Venation regular, internal, reticulated, forming oblique-elongated areoles.

Sori marginal, linear, and continuous.

Indusium narrow.

The genus Doryopteris has some similarity to both Platylomu and Cassebera, yet those of Doryopteris are easily recognised by their reticulated veins. The only difference between Doryopteris and Litobrochia appears to be in their habit, and that is so distinct as to render it desirable to separate them from Pteris.

There is no Brition represcntative of this genus. 
- 


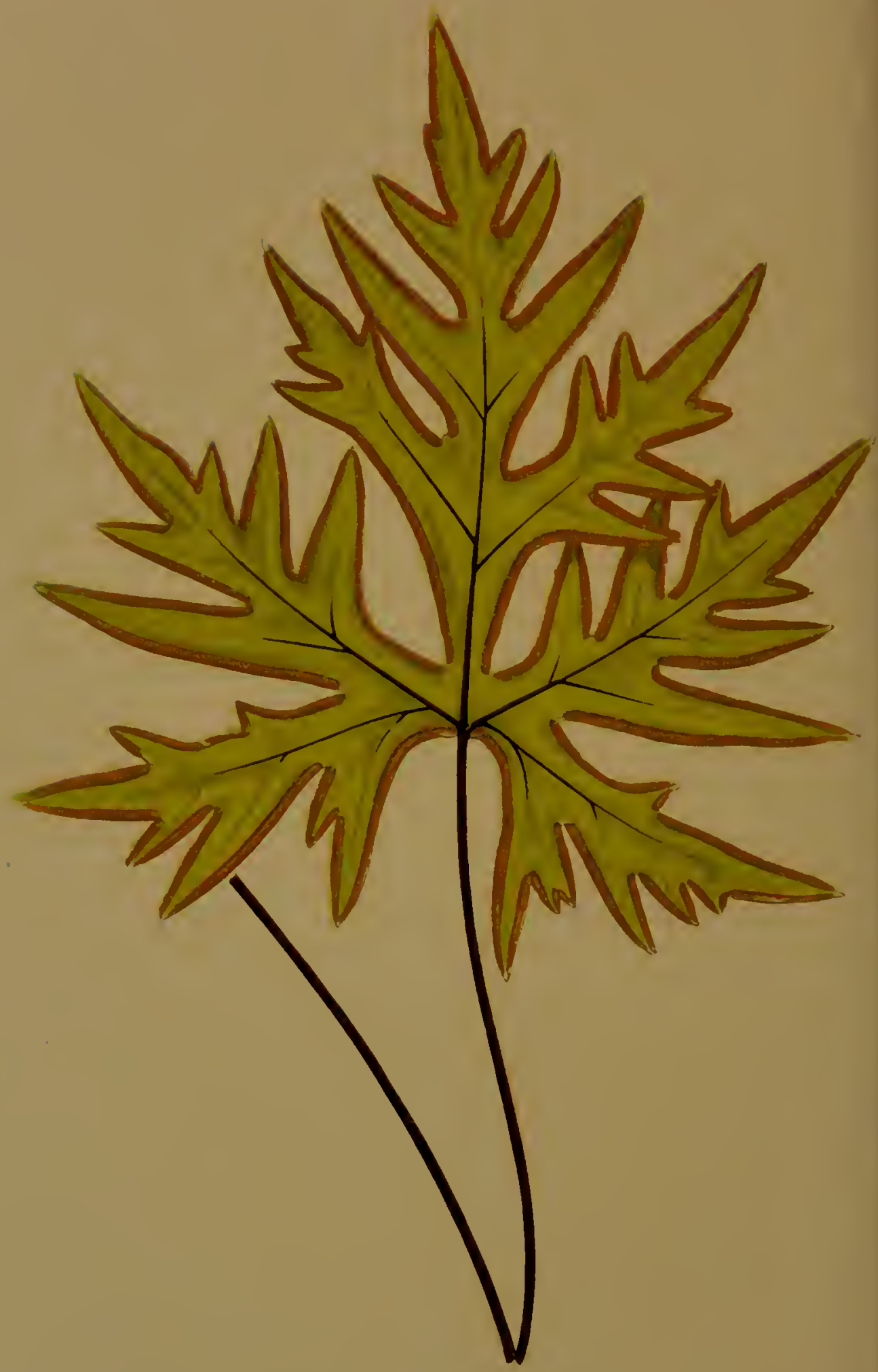




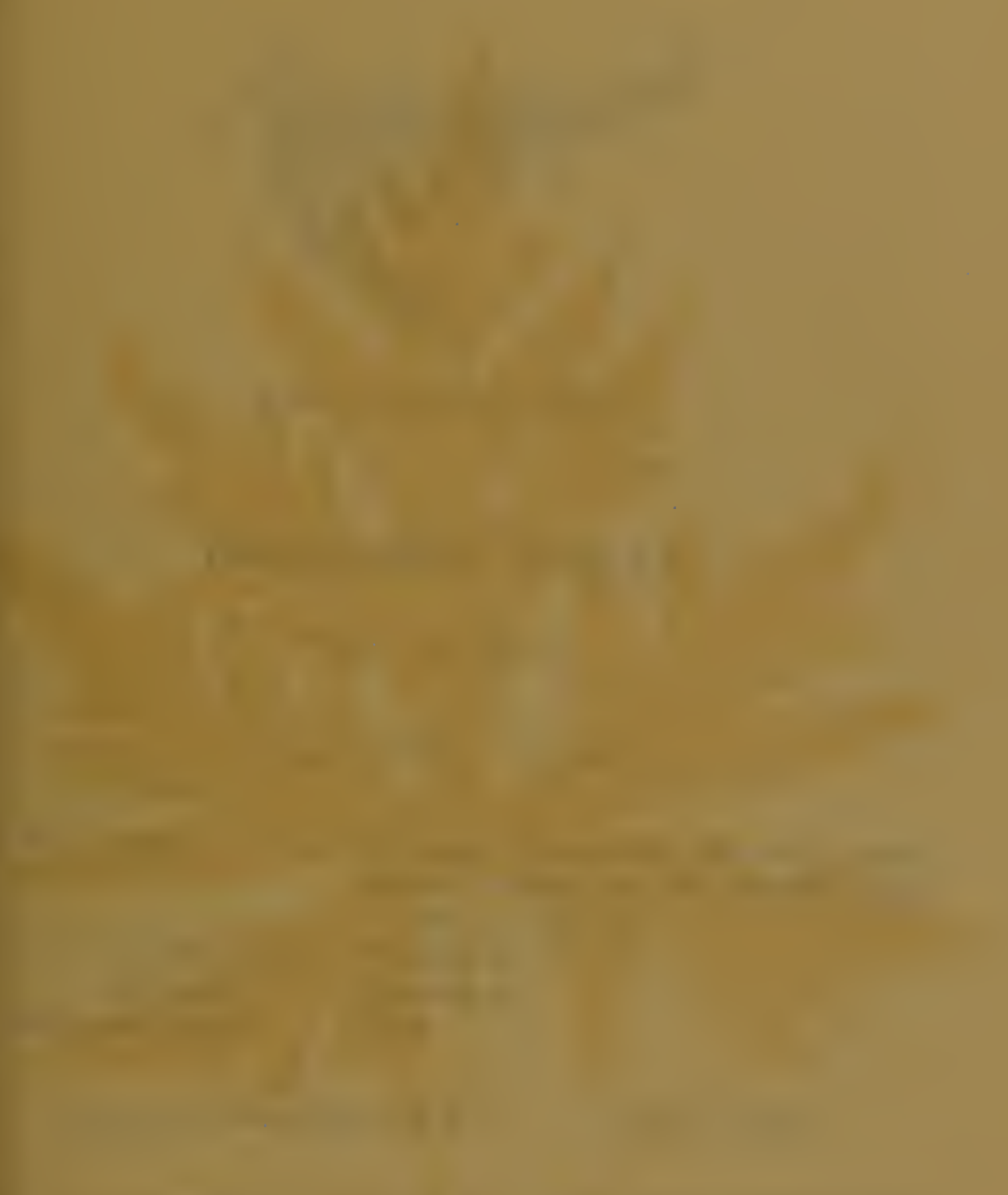

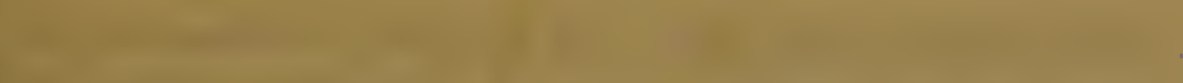

$\cdot$

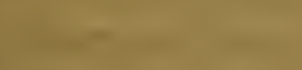

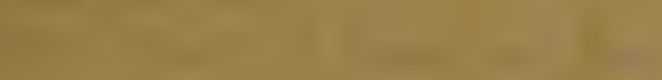

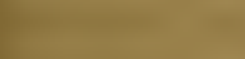

$+\frac{1}{10}$

$\frac{1}{10}+\frac{1}{2}=$

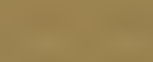

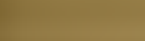

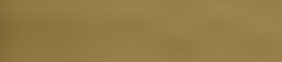

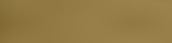




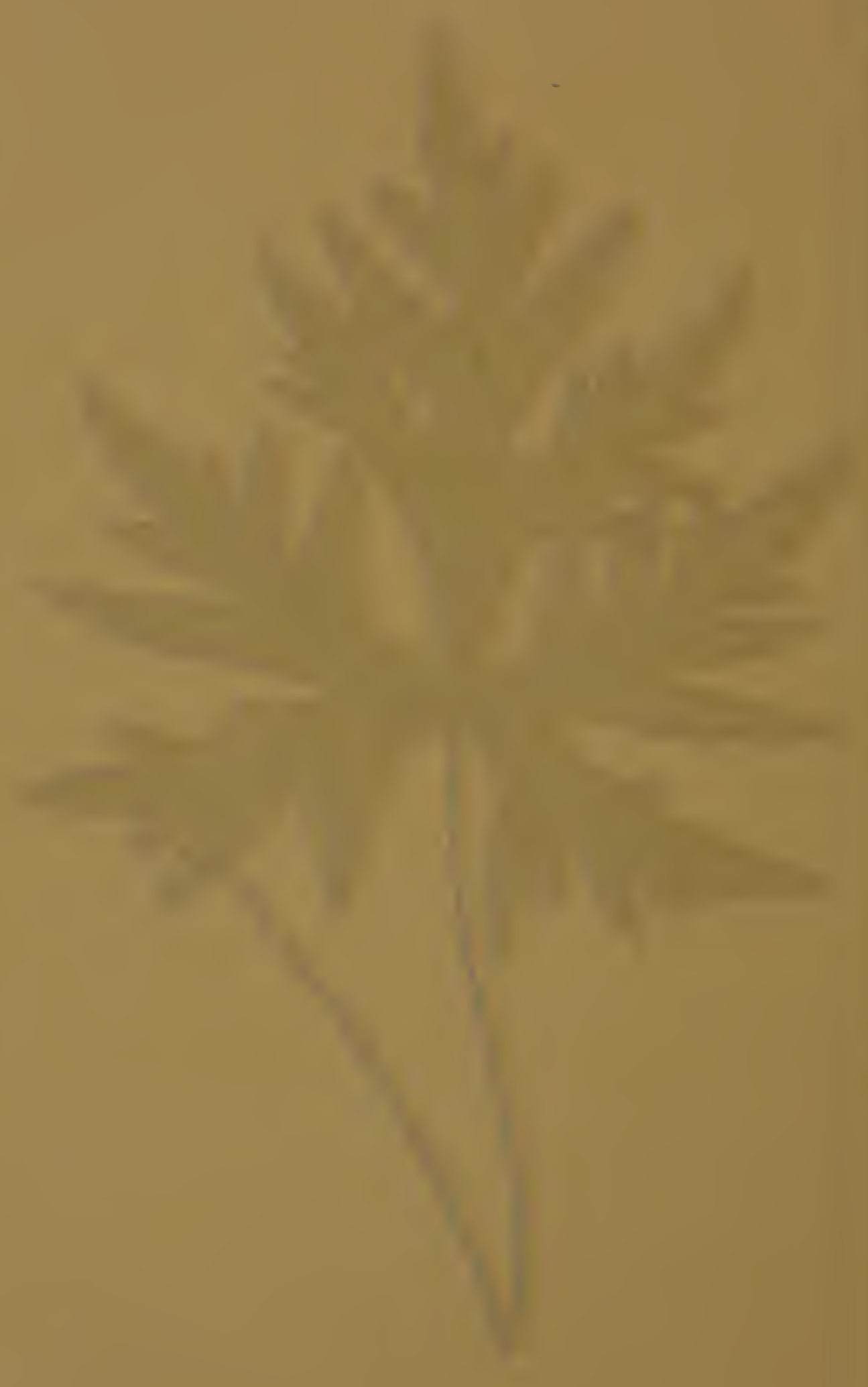




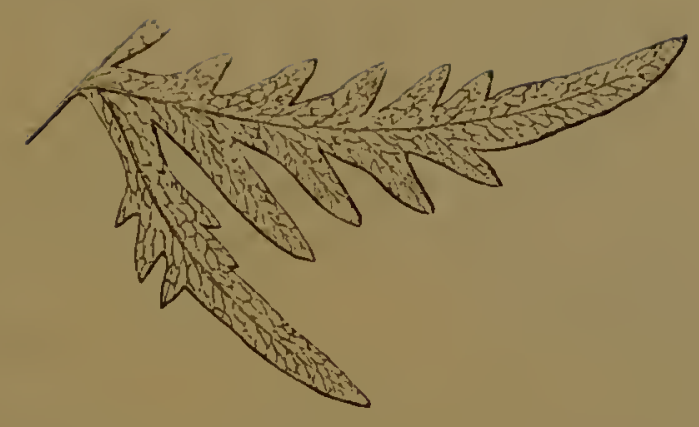

Portion of mature Frond-upper side.

\title{
DORYOPTERIS PEDA'TA.
}

\author{
FeE. J. Silth.
}

IJATE XXXY. VOL. III.
Pteris pedata, Linneus. Willdenow. Schkorr. Link.
" " " Raddi, probably of Plumere, Kaulfuss, and LangsdolrfF.
" digitato-partita, WILLDENOW.
" chenopora, WILLDENow.
Litobrochia pedata, PresL.

Doryopteris-Spear-leaved Feln. $\quad$ Pedata-Pedate.

A DWARF handsome Fern, less than Doryopteris palmata, and yet very much rescmbling that species, although not so much divided on the frond.

An cvergreen stove Fern.

Native of the West Indics and Brazil.

'The fronds, when mature, measuring about five inches in expansion cither way, ternate, parted to the basc, the threc branches springing from the top of the stipes; the lateral oncs two-parted nearly to the basc; both segments deorscly lobed, the -upper also slightly lobed on the anterior side, the lobes variable in size and number, the intermediate branch being cuncate at the 
base. Finally pimatific, with aseendant lobes, of which the lower is largest, the rest diminishing upwards. All the branches terminate in a longish entire apex.

Stipes flat and slightly grooved in front, ebeneous, scaly at the base. Isength of stipes half that of the frond.

Fronds forming a spreading tuft from a short almost ereet or subdeeumbent rhizoma.

Iength of frond from four to six inelies; eolour bright green.

Sori eontinuous.

My thanks are due to Mr. Stansfield, of 'Todmorden, for a plant; and to Mr. Moore, of the Chelsea Botanie Gardens, and to Mr. Henderson, of Wentworth, for fronds.

'There is so mueh confusion regarding the present species, the D. palmata, and D. collina in our Nurserymen's Catalogues, that it would be unsafe to give a list of those supplying the plant.

It is distinguished from D. palmata by its mueh smaller size and more slender proportions, as well as by its deeidedly threcparted fronds, which are never proliferous.

It is distinguished from $D$. collina by its fronds being thinner and three-parted. It resembles $D$. collina in the smaller-sized fronds and non-proliferous eharacter.

The illustration is from a frond kindly forwarded by Mr. Moore, of the Botanic Gardens, Chelsea. 



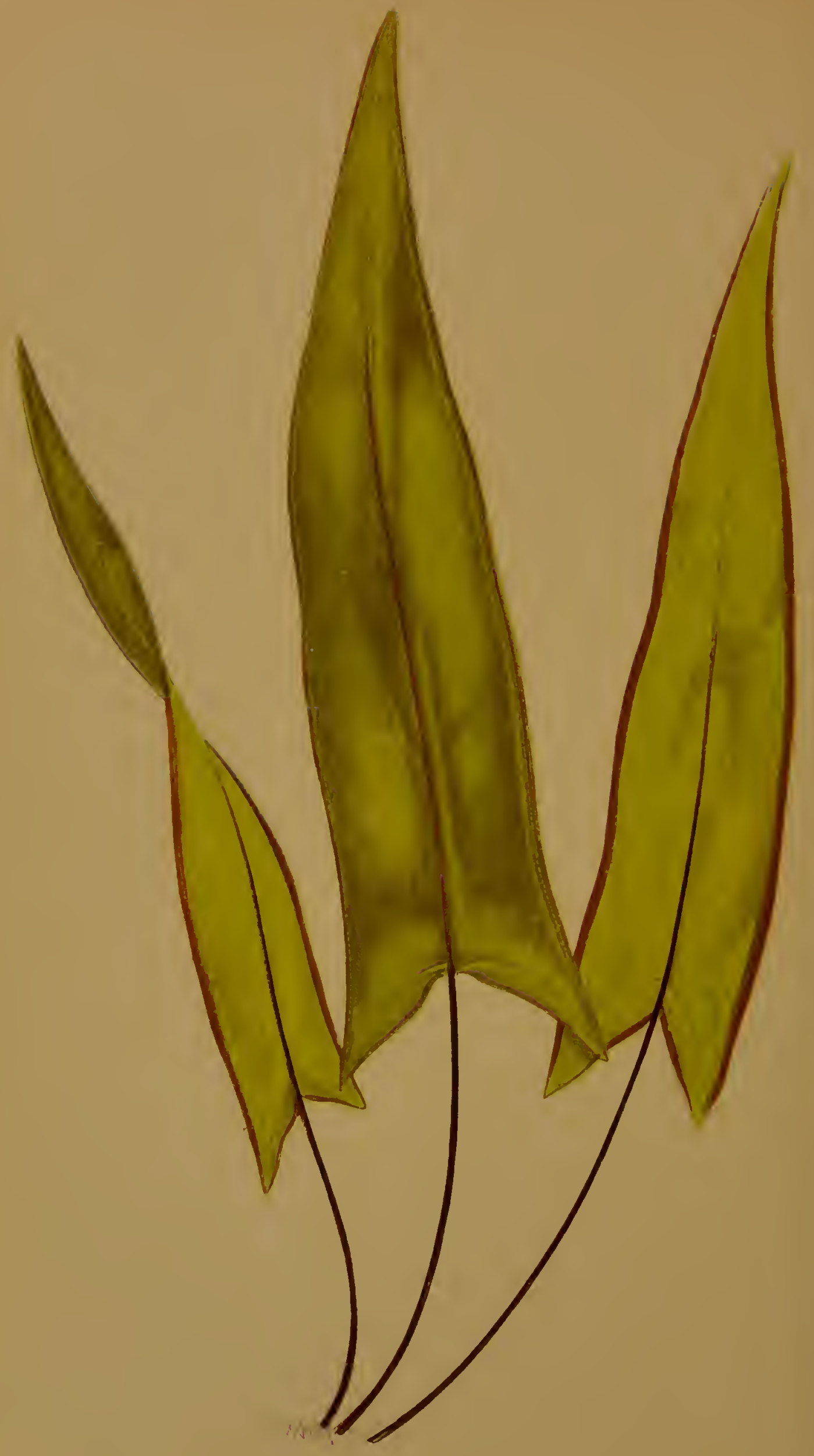




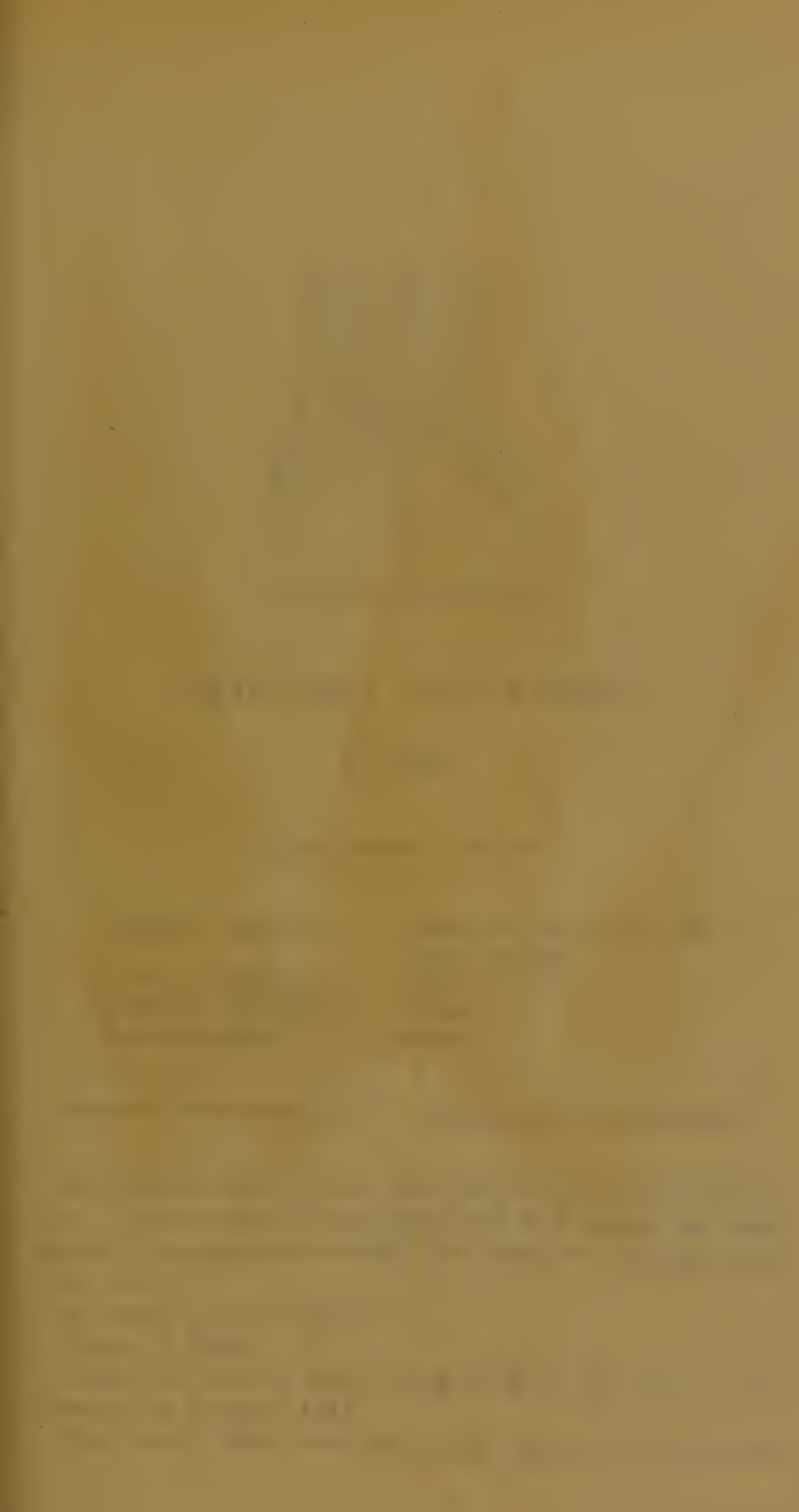




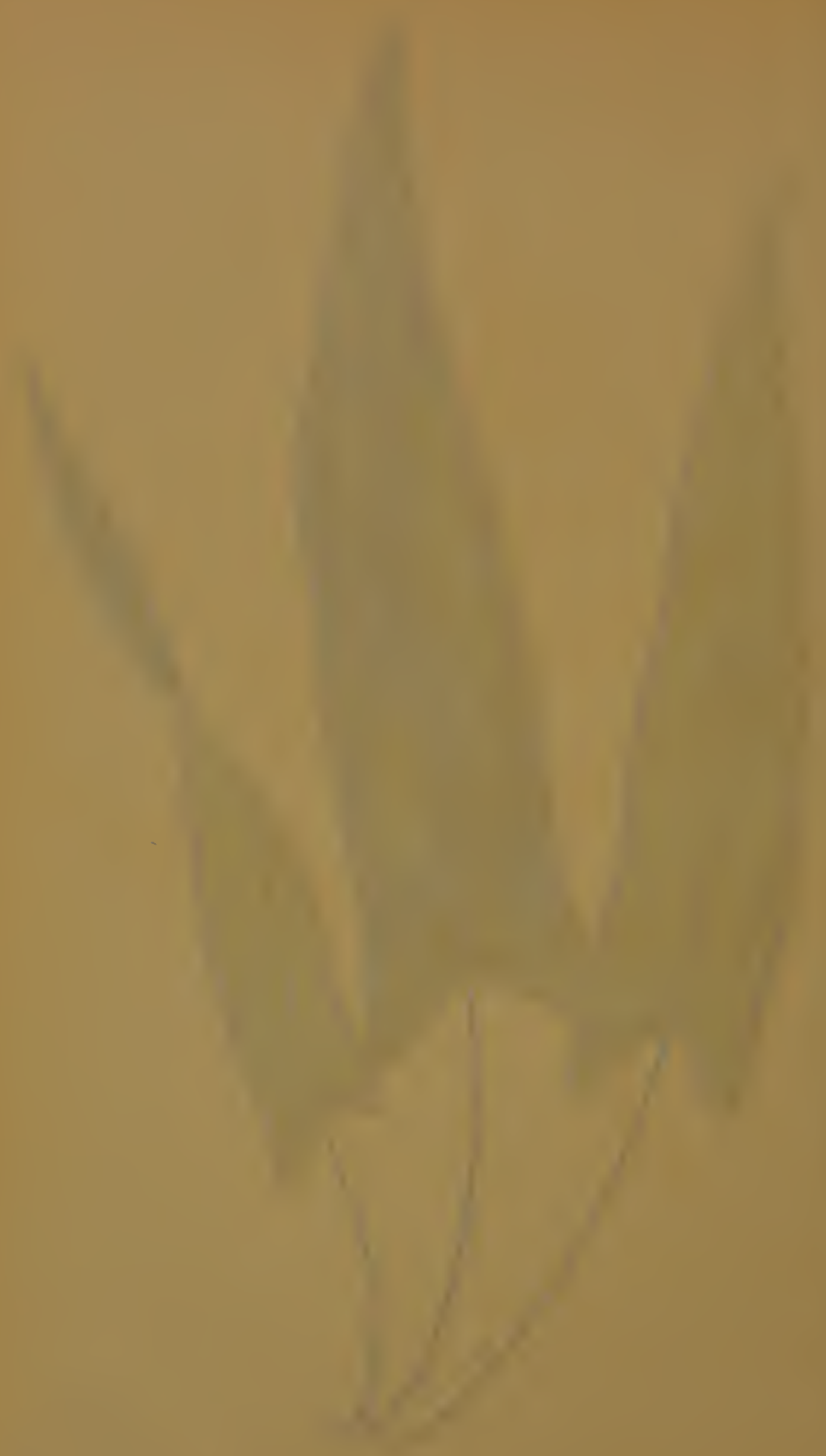




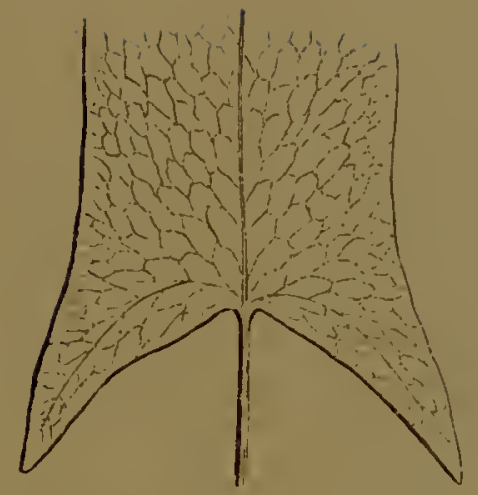

Portion of mature Frond-upper side.

\section{DORYOP'IERIS SAGITTAFOLIA.}

\section{J. SuitiI.}

PLITE XXXI. VOL, III.

Doryopleris sagitlifulia, Moore and Houlston. Fee.

is

" hastifulia, rar.

Lilubrochia sagitlofulia, Pteris sagitlcefolia,
RADDI. KUxzE.

$\mathrm{R}_{\mathrm{ADDI}}$.

PIrest.

RADDI.

Doryopteris-Spear-leaved Ferm. Sagitlafulia-Arrow-head leaved.

Ax cxquisite dwarf species, deserving to be in crery collection. Easily cultivated, occupying but little room, and rery distinct, this pretty arrow-headed Fern must be a farourite with every one.

An cvergreen stove species.

Native of Brazil.

Int:oduced into the Royal Gardens, Few, by Mr. George Gardner, in the ycar 1841 .

The fronds, which are simple, are sagittate, acute, rather 
erect, coriaceons, terminial, adherent to a somewhat crecping rhizomil.

Nearly all the fronds are fertile. Sori linear, continuous; indusium narrow.

Length of frond from six to twelve inches; bright green above, pale green beneath. Stem ebencous.

For plants of this species I am inclebted to Mr. Sim, of Foot's Cray, and to Mr. Parker, of Ilolloway; and for fronds to Mr. Jeans, of Grantham; Mr. Ciark, the Curator of the Glasgow Botanic Gardens; Mr. IIenderson, of Wentworth; and to Mr. Norman, of Hull.

It is in the Catalogues of Messrs. Sim, of Foot's Cray; Parker, of Holloway; Rollisson, of 'looting; Stansfield and Son, of Todmorden; and Kennedy, of Covent Garden.

The illustration is from a plant in ny own collection. 


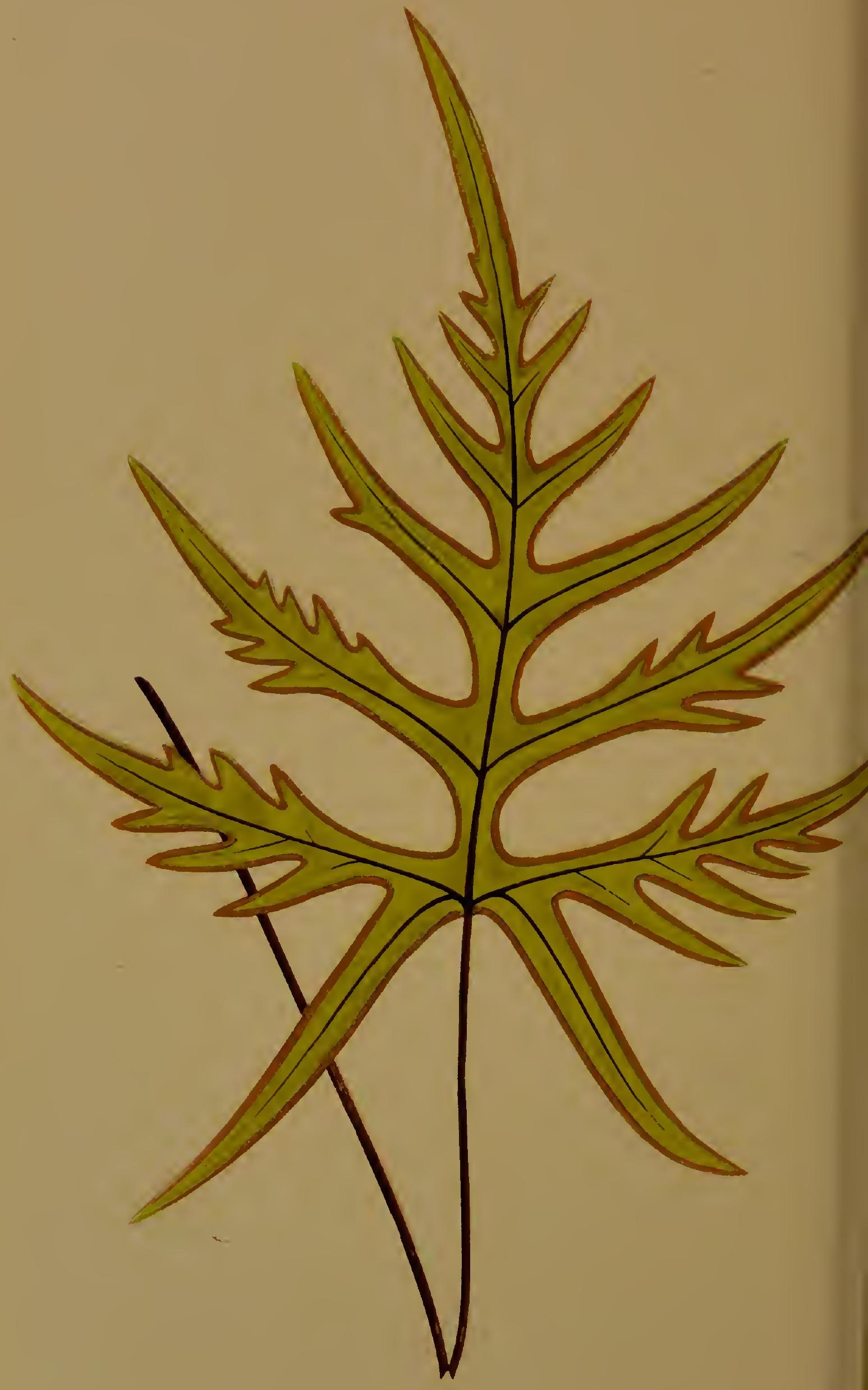




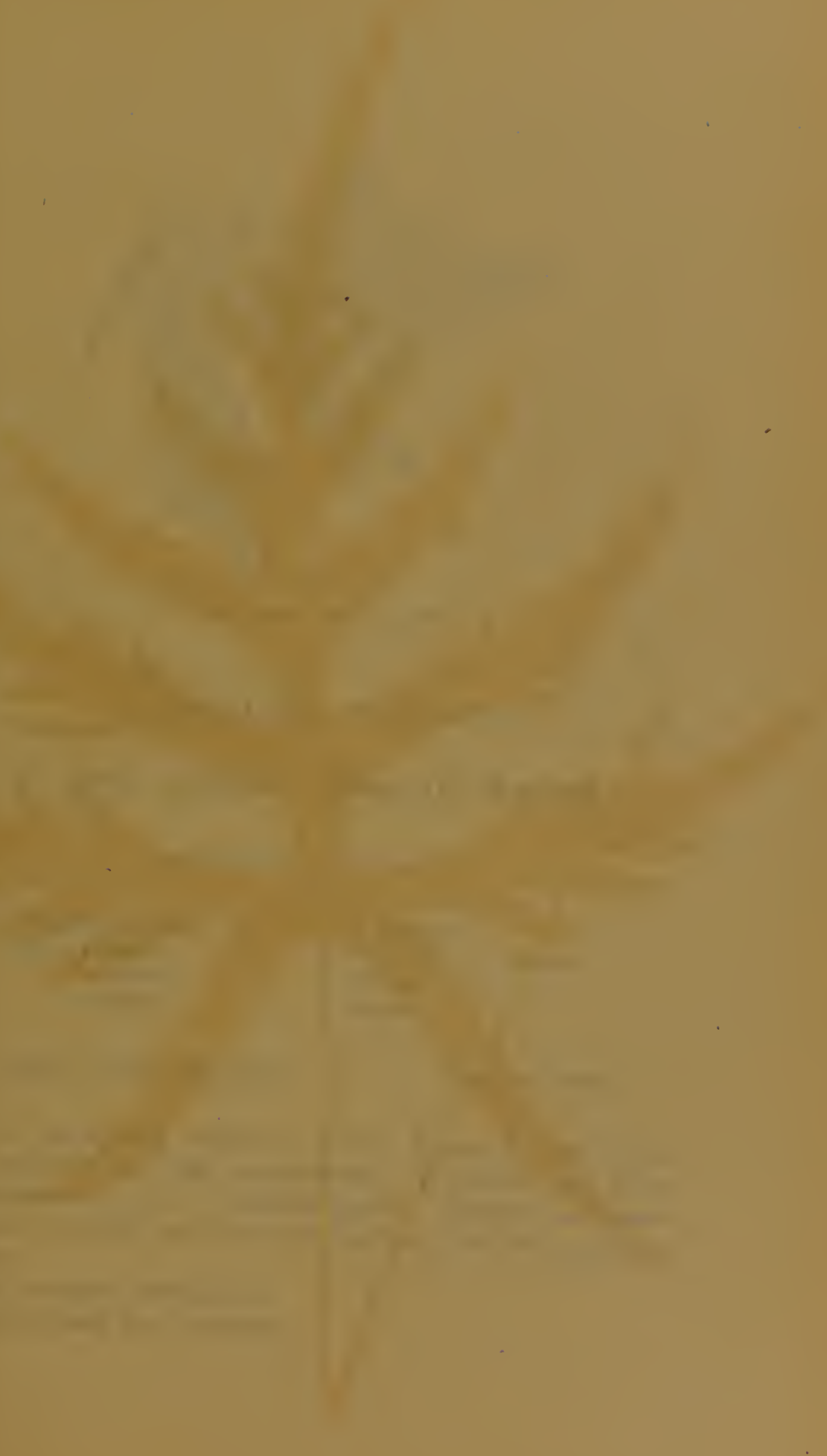





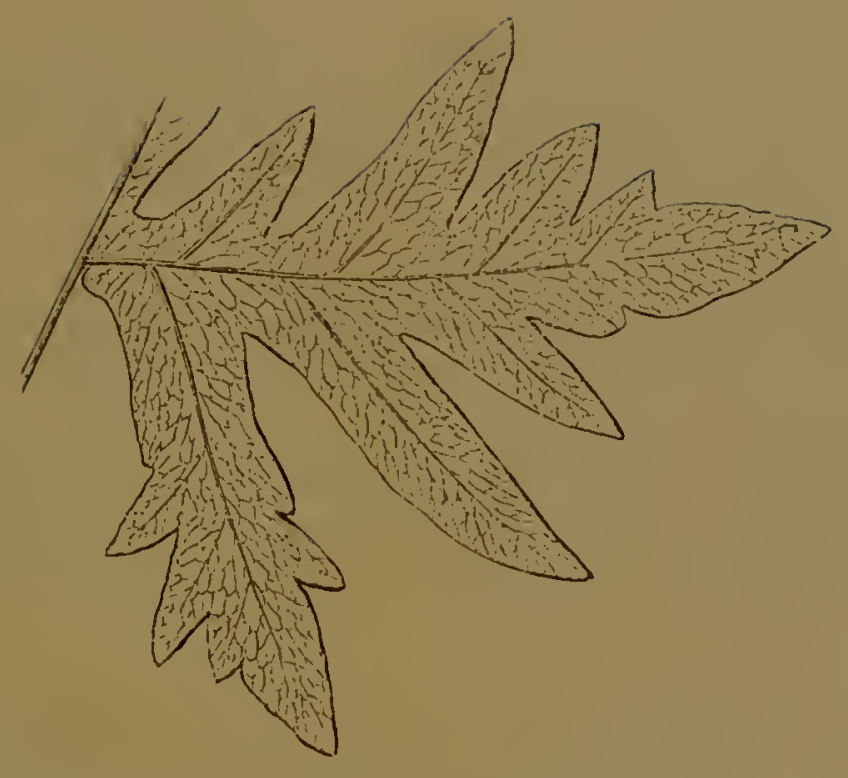

Portion of mature Frond-upper sicle.

\section{DORYOPTERIS PALMATA.}

\section{J. Smith. Klotzsch. Moore and Houlston.}

PIATE XXXVII. TOI. III.

$\begin{array}{cl}\text { Doryopteris pedata, } & \text { J. SuItil? } \\ \text { Pleris palmata, } & \text { WiLLdenow. Kunze. } \\ \text { " anisoloba, } & \text { Kunze. } \\ & \text { Kolytoma, }\end{array}$

Doryopteris-Spear-leaved Fern. Palmala-Paimate.

'Tre Doryopteris palmata is a most beautiful dwarf Fern, not commonly met with in collections. It requires care in its management, as it is a delicate species. Warmth and shade are two essentials, and the plant must not have too much pot-
room.

An evergreen stove Fern.

From Brazil and Venezuela. 
Received into the Royal Gardens, Kew, in 1840 , from the Messis. Loddiges.

The fronds, which are glabrous, are digitately-palnate, coriaceous, drooping, segments linear-acuminate, pinnatified. Stipes near the base squamiferous, terminal, adherent to a short creeping rhizoma.

Sori linear, continuous; indusium plane.

Length of frond twclve inches; colour brilliant grecn.

For plants of this species I an indebted to Messis. Teitcli, of Excter; Mr. Masters, of Canterbury; Mr. Ingram, of the Royal Gardens, Windsor; and Messrs. E. G. Henderson, of St. John's Wood; and for fronds to M. Schott, of the Imperial Gardens, Vicnna, and to Mr. Moore, of the Chelsea Botanic Gardens.

It is in the Catalogues of Messis. E. G. Ifenderson, of St. John's Wood; Bass and Brown, of Sudbury; Osborn, of Fulham; Veitch, of Exctcr; Sim, of Foot's Cray; Teitch, Jun., of Chclsca; Masters, of Canterbury; Rollisson, of Tooting; Parker, of Holloway; Stansficld, of 'Todmorden; and Kcnnedy, of Covent Garden.

The illustration is from a plant in my own collection. 


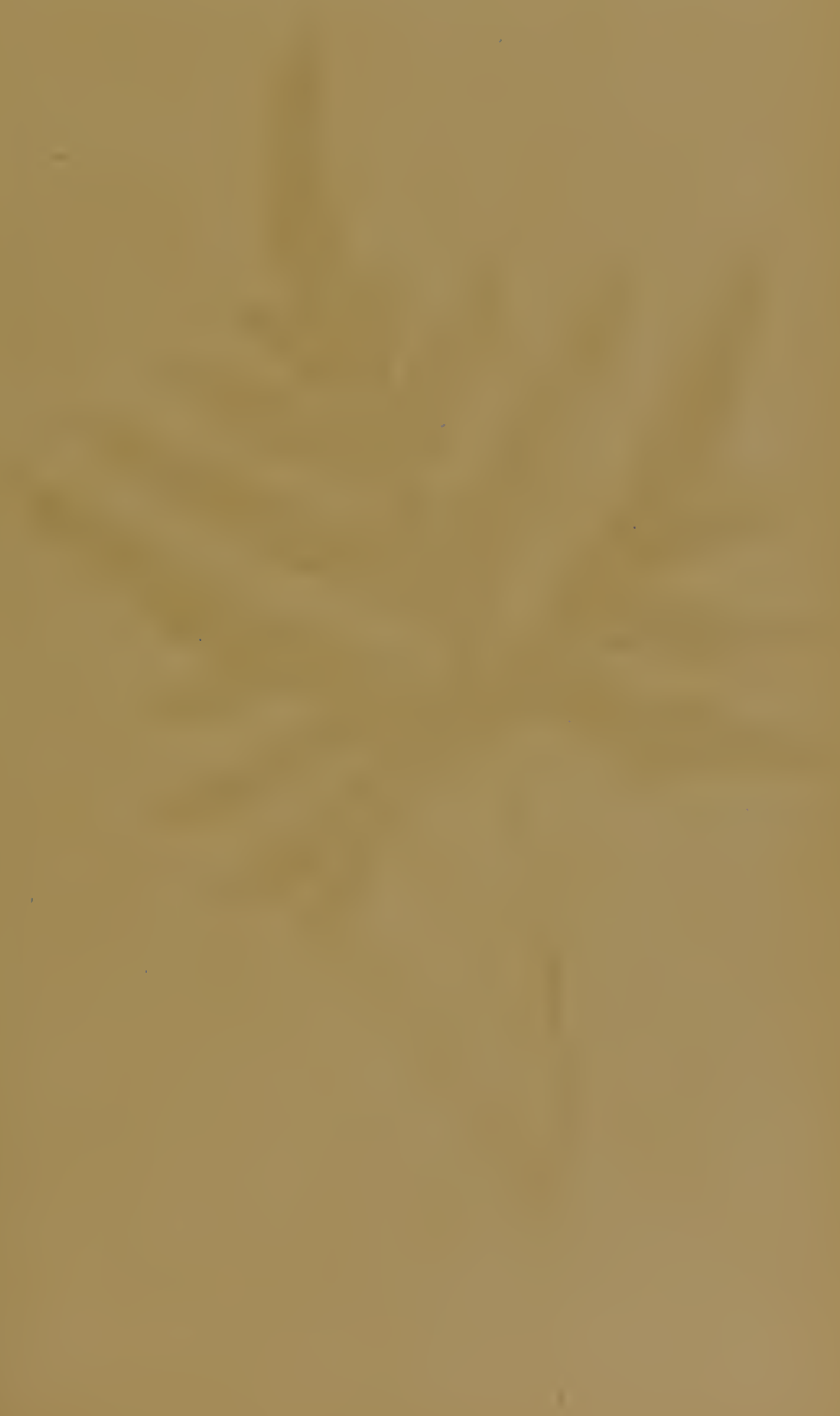




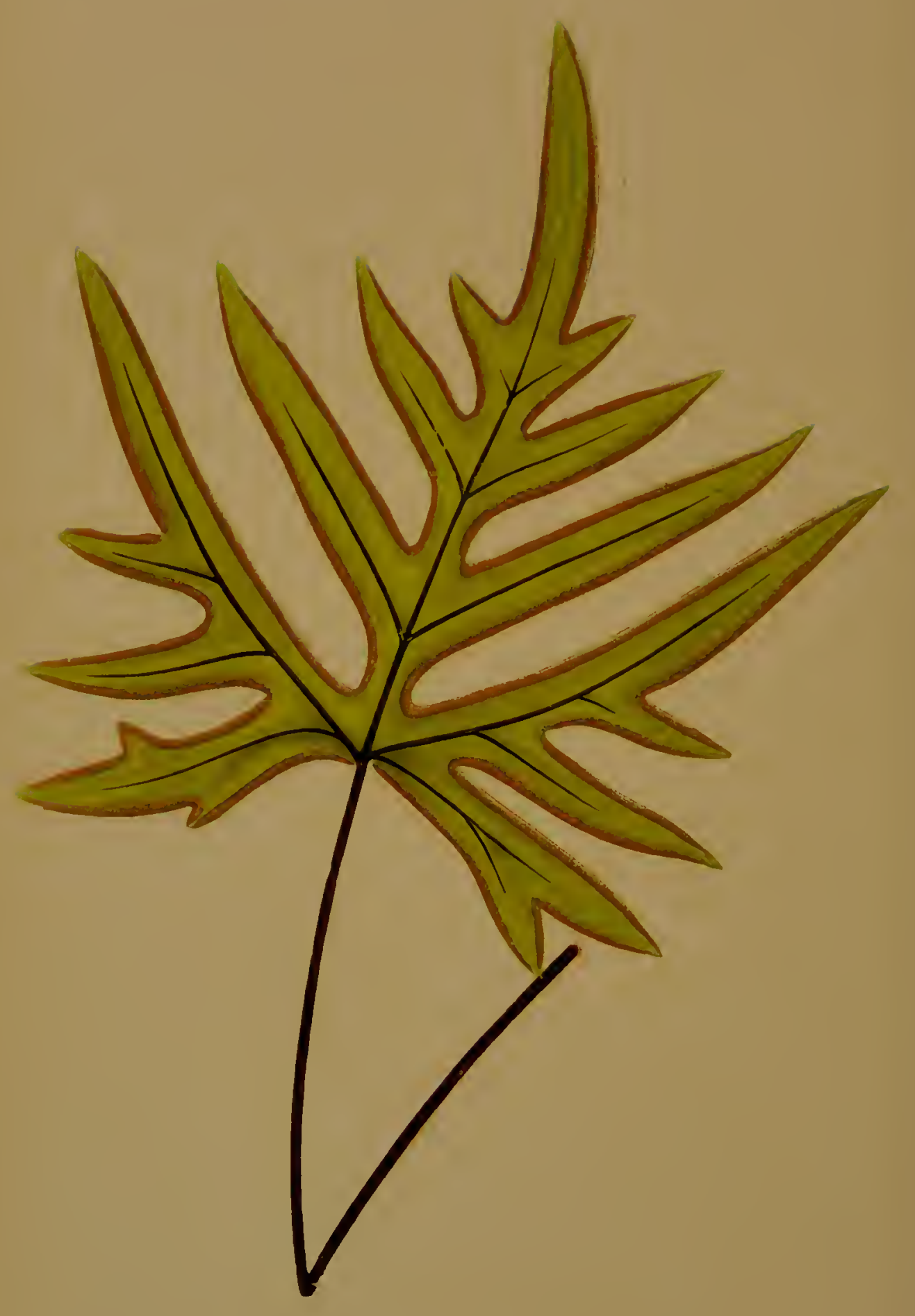




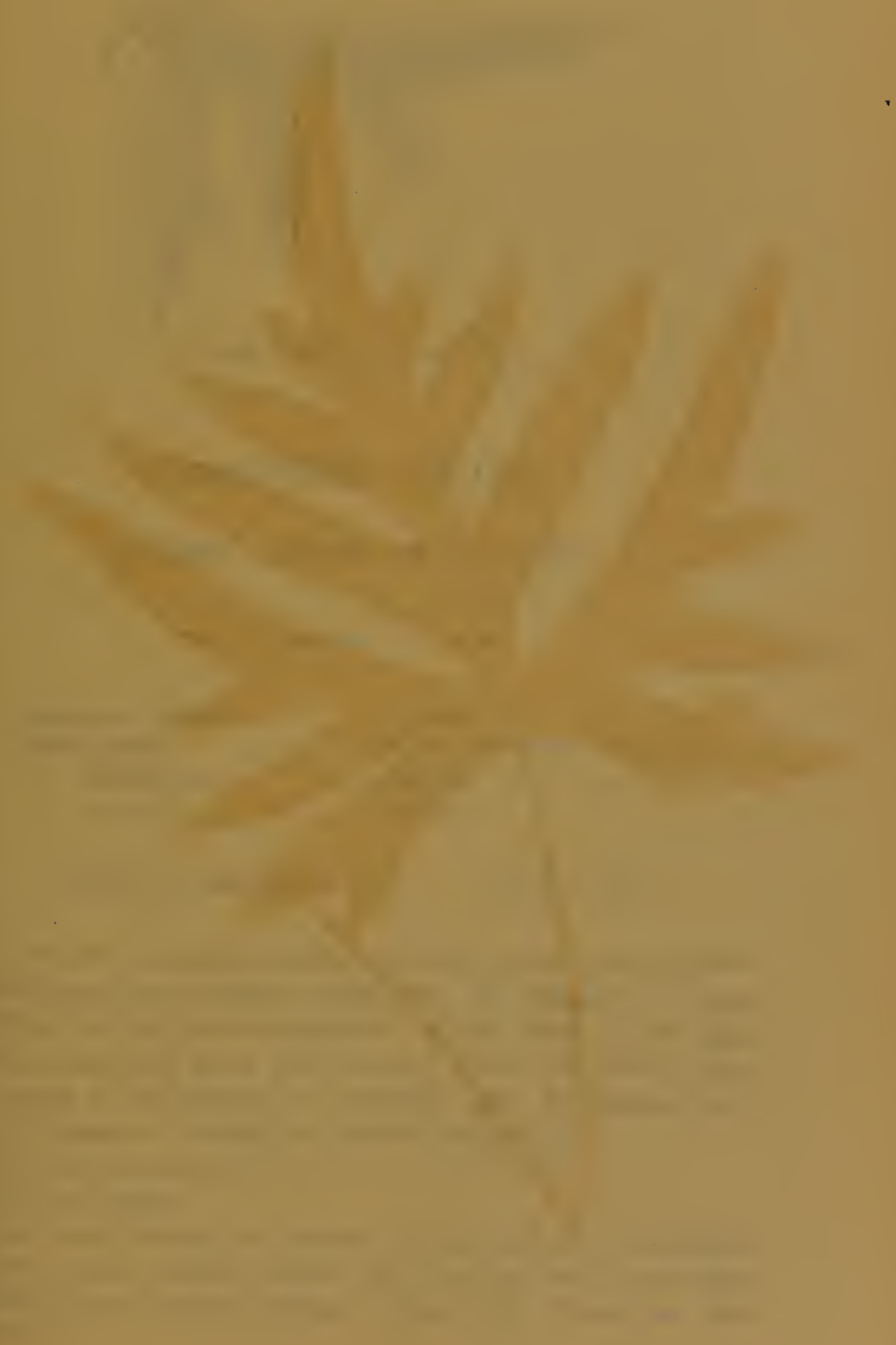




$$
\text { 事 }
$$




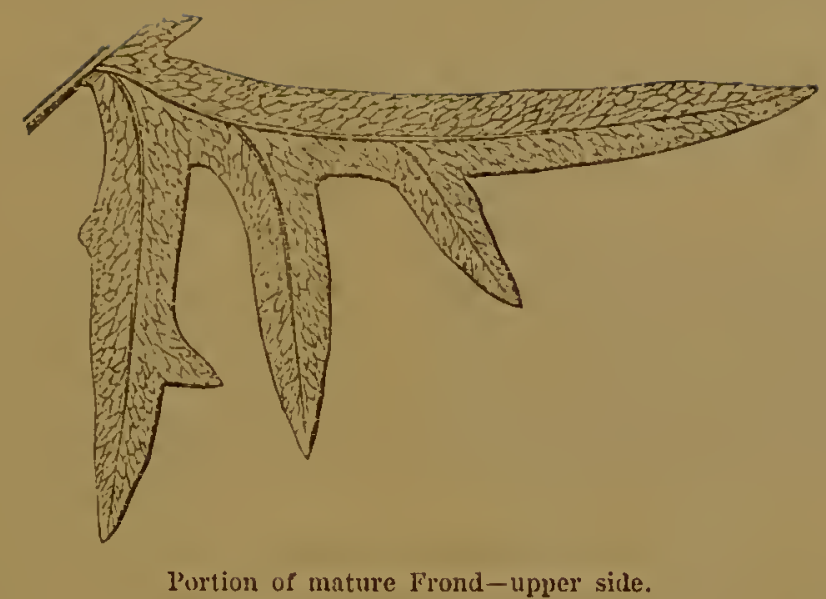

\section{DORYOPTERIS COLLINA.}

\section{J. Suith. Moore and Houlston.}

PI.ATE XXXYII. VOI. IIT.

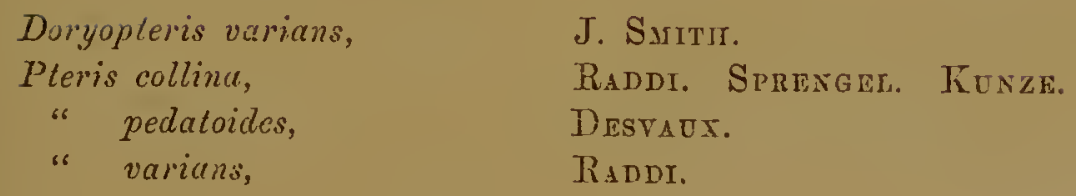

Doryopleris-Spear-leaved Fern. Collina-A hill.

A SOMEWhat similar-looking, beautiful species, but dwarfer in habit, and with smaller fronds than D. palmata; not commonly to be met with in gardens. There seems to be some confusion regarding these Ferns, as they are to be found under the names of $D$. collina, D. palmata, and $D$. pedata, as if only one species. Worthy of gencral cultivation.

An cvergreen stove Fern.

Native of Brazil.

The fronds, which are glabrous and coriaceous, are palmate in form. 'The sterile fronds are three or five lobed, with roundish obtuse blunt segments. 'The fertile fronds are five YOL. III. 
parted, having lincar-lanceolate pinnatifid scgments; the inferior elongatc.

Sori linear, continuous; indusium planc.

Length of frond from six to ten inches; colour bright green.

Fronds terminal, adhercnt to a somewhat crecping rhizoma.

For a plant of this specics I am indebted to Messis. Stansfield, of Todmorden, and for fronds to Mr. Thomas Moore, Curator of the Chelsea Botanic Gardcns, to whom I am also much indebted for valuable information regarding the Doryopteris family.

A list of Nurserymen supplying this species is onitted, as it is uncertain which Fern is meant.

The illustration is from a frond forwarded by Mr. Moore. 


\section{GENUS VI.}

\section{P'TERIS. LINxAUs.}

THE family of Ptcris has been very much cut up into groups and distinct familics, some of which are very near neighbours to Pteris. Of these Mr. Smith, in his Catalogue of the Ferns in the Royal Gardens, Kcw, has the following:-

1.-Criptogramma, a very un-Pteris looking solitary Fern.

2.-Pellea, eight species.

3.-Plutylomu, three species.

t.-Doryopteris, two species.

5.-Pteris, nineteen species.

6.-Litobrochic, nine species.

7.-Lonchitis, one specics.

Kunze, in his "Index Filicum," has the following:-

1.-Allosorus, fiftecn species, including Smith's genus, Cryptogramma, Pellcea, and Platyloma.

2.-Lonchitis, two species.

3.-Ptcris, fifty-two species, including Doryopteris and Litobrochia.

P'esl, in his "'Tantanen Ptcridographix," contains:-

1.-Pteris, an extcnsive genus.

2.-Monogonia, one species.

3.-Cumpteria, six species.

4.-Litobrochia, an cxtensive genus.

5.-Amphiblestra, two species.

(j.-Allosorus, an cxtensive genus.

T.-Lonchitis, thrce species.

Moore, in his "Genera and Species of Cultivated Ferns":-

1.-Cassebera, five species.

2.-Platyloma, eight species.

3.-Doryopteris, threc species.

4.-Litobrochia, five species.

i).-Lonchitis, one species.

6.-C'empteriu, one species.

7.-P'teris, fourteen specics. 
8.-Onychium, one species.

$\mathrm{Fec}$, in his "Genera Filicum":-

1.-Pteris, a large family.

2.-Pellaa, an cxtensive family.

3.-Phorolobus, three species, including Cryptogramma.

4.-Onychium, nine specics.

5.-Doryopteris, seven species.

6.-Litobrochica, a large family.

T.-Heterophlebium, one species.

8.-Amphiblestri, one species.

9.-Lonchitis, nine species.

In the present work Platyloma has becn scparated from Pteris, but the division Pelloe has been retained as a section of Platyloma, rather than devoting a genus to it. Doryopteris and Onychium are also treated each as a distinct genus; whilst Litobrochia, Lonchitis, and Campteria, are placed as sections of Pteris.

'There is a solitary represcntative of this cxtcnsive family in Great Britain, viz.-Pteris aquilina, and, strange to say, this species has a rery great geographic range, although bearing il different name in several countrics. Mr. Noore mentions the following as species not to be distinguished from our Pteris aquilina:-

P. lamuginosa, Bory. Ceylon, Mauritius, and Abyssinia.

P. decompositu, Presl. Sandwich Islands.

P. caudutu, Limnxus. North America and Jamaica.

$P$. recurvata, Wallich. Nepal.

P. arachnoidea, Kaulfuss. Rio de Janeiro, Brazil, 'Trinidad.

P. esculenta, Forster. New Holland.

'The name Pteris is derived from Pteron-al wing, in reference to the form of the branching of the fronds of this genus. Mr. Moore remarks that originally the fimily of Pteris cmbraced nearly two hundred species, but from subdivisions and by the recognition of the sime species nunder two or more names the number has been greatly reduecd.

Mostly the species are tall coarse-growing licrns, very casily cultivated; the length of fronds varying from one to ten fect. They are pinmate, bipimatifid, or dccompound, ghibrous or pilose. Veins forked, the renules being direct, and having the apices counceted logether by a sporangifcrous receptacle. 
Sori linear, continuous, or interrupted, generally only occupying the sides of the segments.

Indusium plane, linear, with its base often sporangiferous.

In the section Litobrochia, the veinlets, instead of being direct, are reticulated. 'They are mostly large branching Ferns, of a flaccid texture.

In the section Lonchitis, the veinlets, are also reticulated as in Litobrochia, yet they differ in the position of the sori; instead of being linear, and occupying more or less of the sides of the segments, it is situated in the sinus of the segments, and is more or less the form of a segment of a circle.

In the section Campteria the difference is in the venation, taking a midway eharaeter between the true Ptcris and Litobrochia. The veinlcts are direct except a single row of costal venules, which anastomose.

Thus in the above the transition from Pteris through Campteria and Lonchitis to Litobrochia, is so gradual, that the example of Kunze has been followed, in retaining them as sections, in preference to scparating them cntirely from Ptcris. 


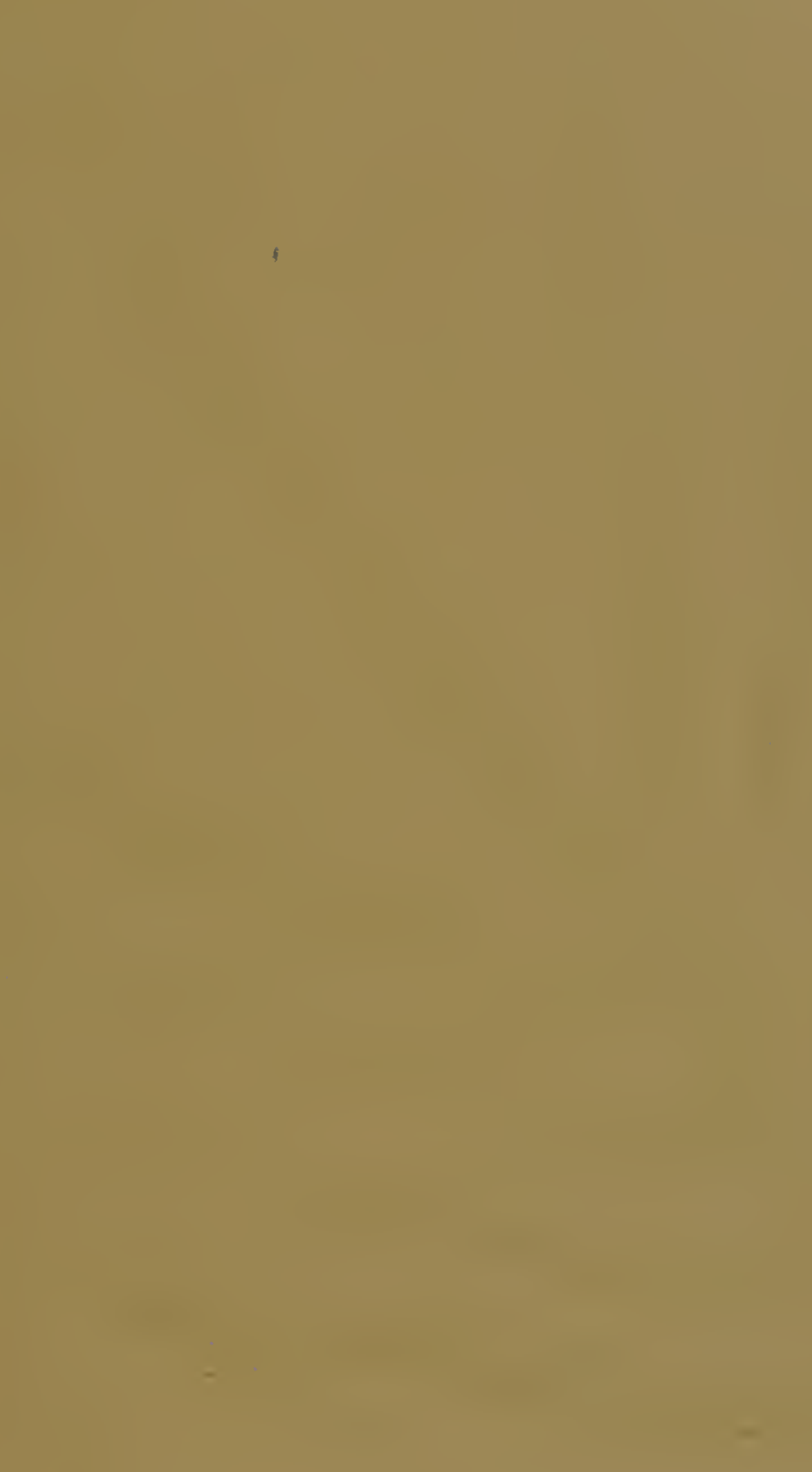

$\vdots$ 


$$
\text { Es }
$$




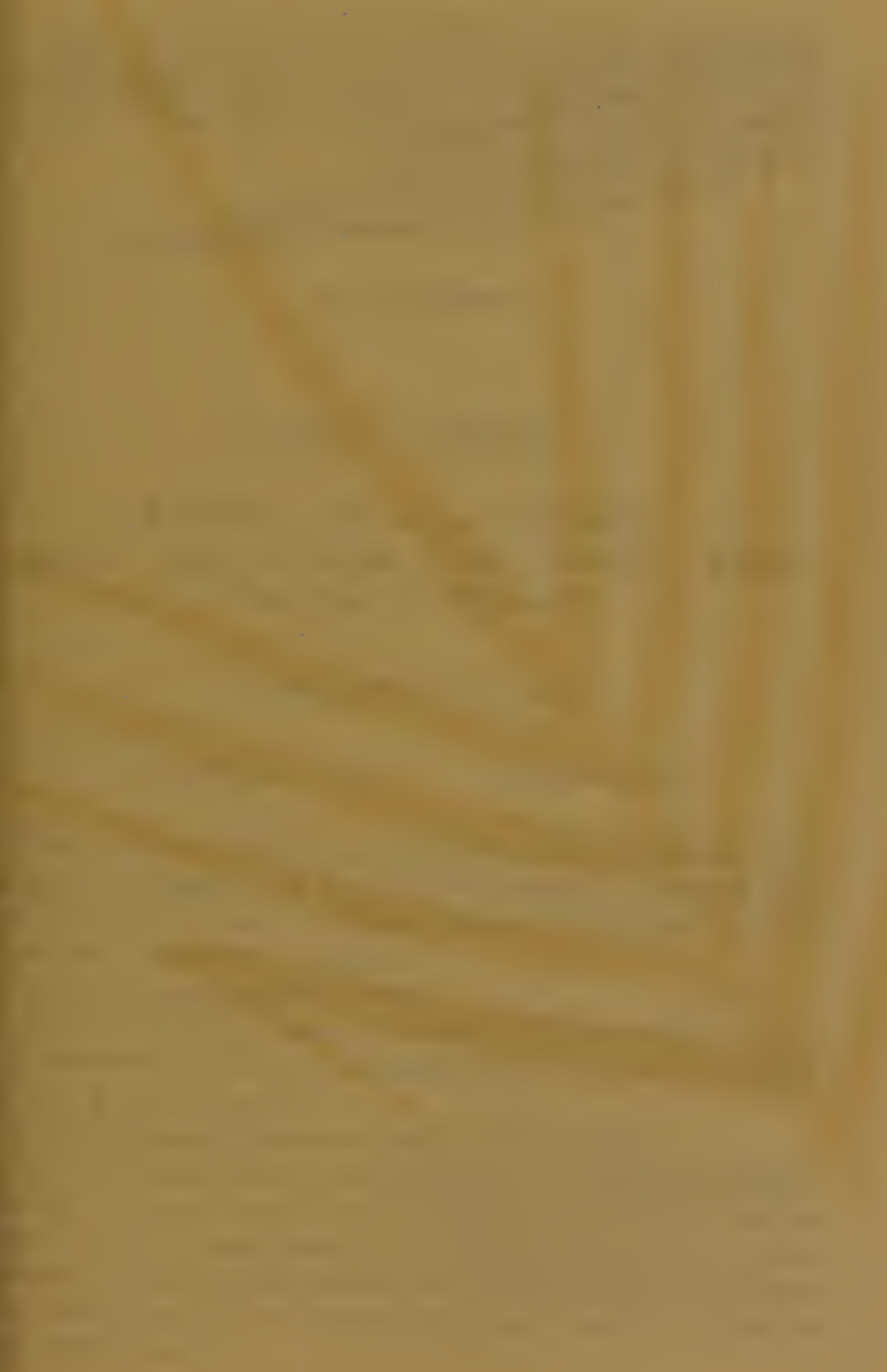





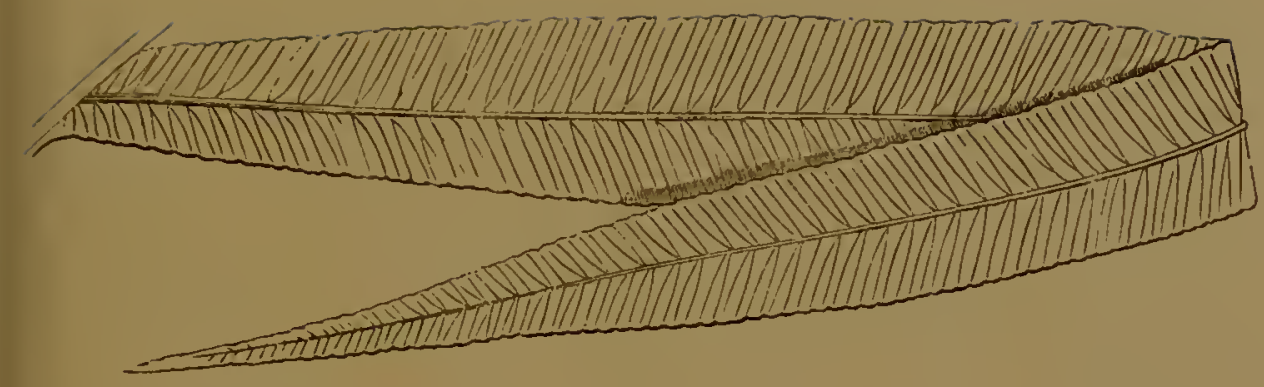

Pinna of barren Frond.

\section{PTERIS UMBROSA.}

\section{R. Brown. Moore and Houlston. \\ Sieber. Fee. J. Smith. Link. Agardh. Kunze. Presi, (not of WALLICH.)}

PLATE XXIIX. VOI. III.

$$
\text { Pteris-Brake. Umbrosa-Shady. }
$$

Fww Ferns are able to vie with the Pteris umbrosa in its elegance of growth. It is a tall, erect-growing, large species, with weeping pinnx. With abundance of pot-room it forms itself into a handsome specimen.

An evergreen greenhouse Fern.

Sative of New Holland, New South Wales, and Australia. Introduced into the Royal Gardens, Kew, in the year 1824 , by Mr. A. Cunningham.

Fronds glabrous, bipinnate below, pinnate above.

In the sterile frond the segments are linear-acuminate, having a serrated margin, and being decurrent at the inferior basc. In the fertile frond the segments are linear, narrow, serrated at the apex, and decurrent at the inferior base; often ten inches long. The barren pinne only half the width of the fertile pinna. 
Fronds lateral or terminal, adherent to a brief creeping rhizoma.

Sori continuous, extending to within an inch of the apex of the segments, and along the decurrent base; when young green, afterwards reddish brown, and reflected over the edge.

Length of frond from two to three fect; colour splendid bright green. In my plants the barren fronds are two fcet long, having a stipes one foot three inches in length; the fertile fronds three feet three inches, having a stipes two fect in length.

Stipes on the upper side flat and fluted, lower side circular, colour of under side brownish, upper side mostly green; darker and scaly near the base.

My thanks are due to Mr. Henderson, of Wentworth, for a plant of this species; and to Mr. Norman, of Hull, for fronds.

It may be procured from Messrs. Sim, of Foot's Cray; Parker, of Holloway; Rollisson, of 'Tooting; A. Henderson, of Pine-apple Place; Veitch, Jun., of Chelsea; Booth, of Hamburg; Kennedy, of Covcnt Garden; and Stansfield and Son, of 'Todmorden.

In very large species, it has been found impossible to figure a whole frond without reducing it so materially in size, that it is scarcely to be recognised; it has therefore been deemed more adrisable in these instances to figure portions only of the fronds.

The illustration is a portion of a frond from a plant in $\mathrm{my}$ own collection. 



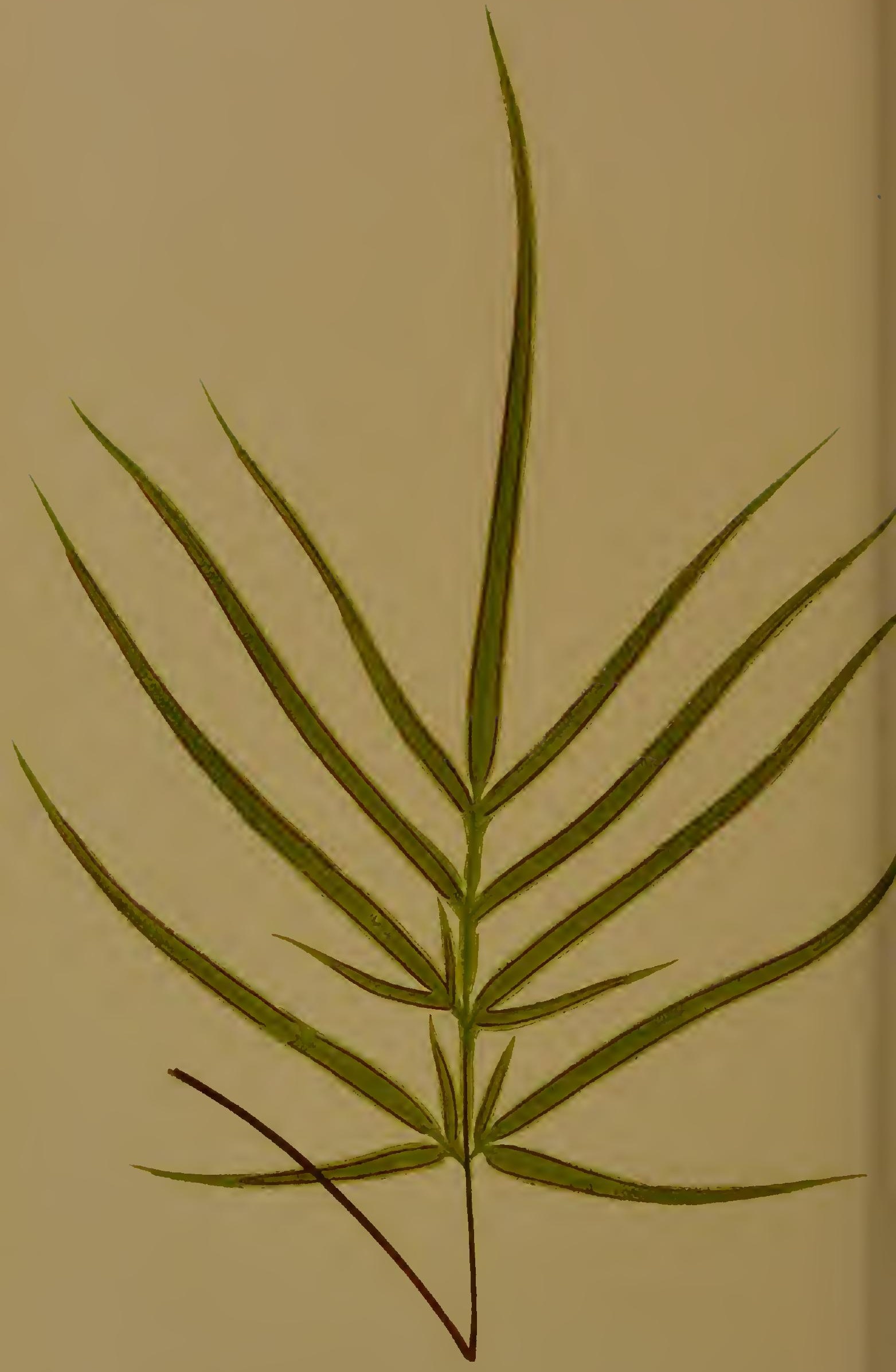





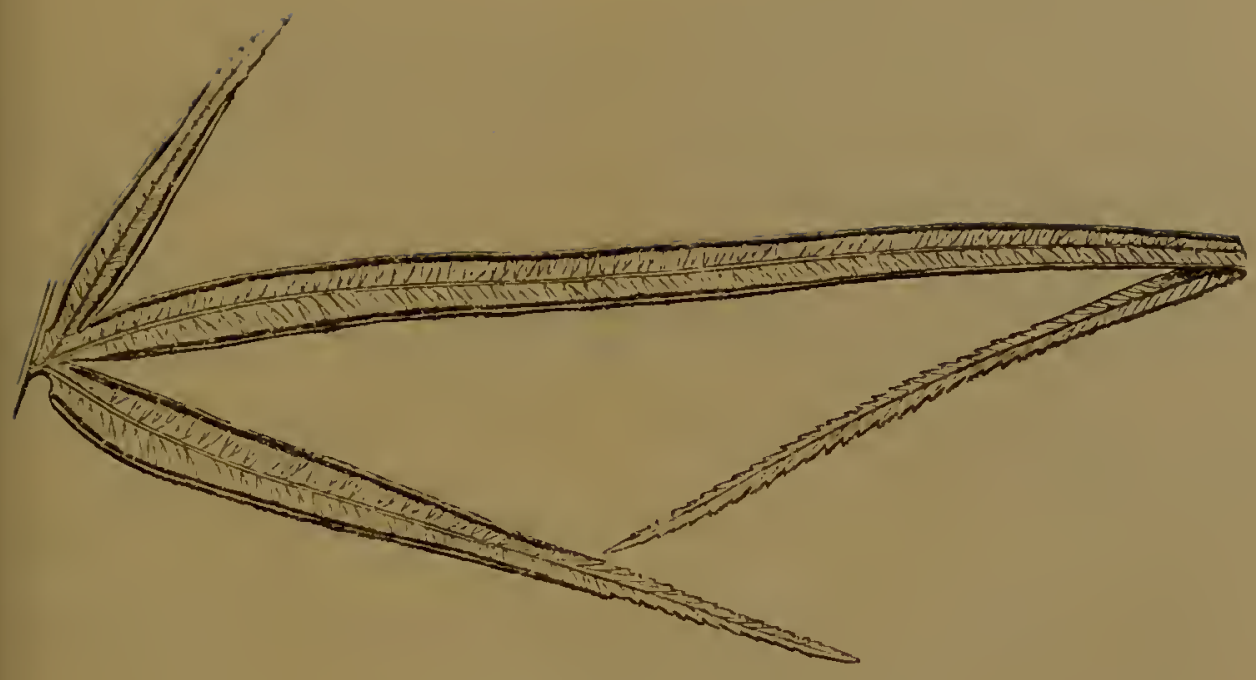

Portion of mature Frond-under slle.

\section{P'TERIS SERRULATA.}

Linnaus. Moore and Houlston. Willdenow. Fee. Schruhr. Plukenet. J. Smitil. Link. Agardi. Kunze. Presl. Schott, MS.

PIATE XI. V(OI. III.

Previs multifulu.

PoIRET.

$$
\text { Pteris-Brake. Serrulata-Saw-edged. }
$$

P'teris scrrulata nua be said to be the most eommon exotic Fern known in Fingland. It requires no eare or trouble in its managoment, and young plants from spores spring up in all the Fern-pots in the houses where it is grown, so as to constitute itself a troublesome, yet pretty exotie weed. Even in eollections of plants where Ferus are not grown, the $P$. serrulate may be found thrusting itself into the notiee of evcry onc. A very singular looking speeies, and well worthy of cultivation.

VOL. III. 
An evergreen stove Fern.

A native of the East Indies, Japan, and China.

Fronds slender, glabrous, pinnate; the pinnx being linear ratlier pendulous, and would be more so were it not that the fronds hold up one another. The lower pinnæ bipartite or bipinnatifid and petiolulate; the upper ones adnate. Deeurrent at their inferior base. The margin of the stcrile fronds scrrate; the fertile fronds have narrower linear segments. Fronds lateral or terminal, attaehed to a short ereeping rlizoma. Nearly all the fronds fertile.

Length of frond from twelve to eightecn inehes; eolour light green.

I am indebted to M. Sehott, Direetor of the Imperial Gardens, Vienna, for fronds of this speeies.

There are several varieties of this speeies, two of whieh are here notieed.

Tar. $A$. is more pendulous in labit, taking a eharaeter midway between $P$. serrulata and $P$. umbrosa.

Var. B. is mueh more dwarf, not so many-branehed, only the two lowest pinnx being branehed. The plant was reeeired from Mr. James, of Taurcrt, in Guernsey, under the name of P. falcata.

There is a variety of this speeies whieh only grows three inehes high, and having a peeuliar rugose habit. It was raised (from spores brought from the islands of the Indian Sea,) at Wentworth, by Mr. J. Henderson. It is known nnder the name of $P$. serrulata, minor.

Introdueed into England in the year $17 \% 0$.

Included in the Catalogues of Messrs. E. G. Henderson, of St. Joln's Wood; Bass and Brown, of Sudbury; Kennedy, of Covent Garden; Veitelh, of Excter; Veiteh, Jun., of Chelsea; Sim, of Foot's Cray; Cooling, of Derby; A. Henderson, of Pine-apple Plaee; Masters, of Canterbury; Rollisson, of Tooting; Parker, of IIolloway; and Stansfield and .Son, of 'Todmorden.

The illustration is from a plant in my own collection. 




\section{9}<smiles>C1CCC1</smiles>

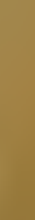

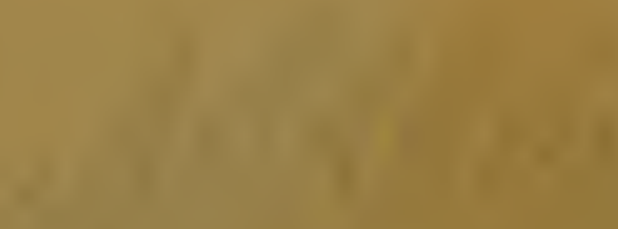

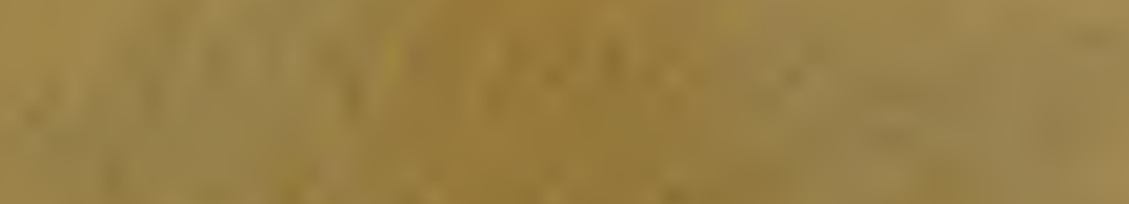

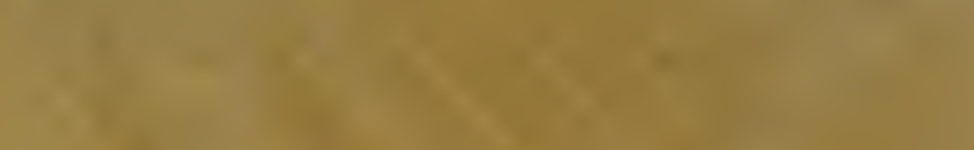

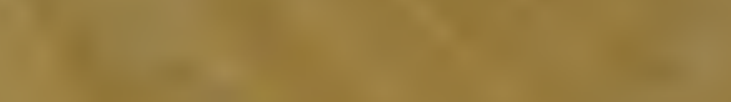
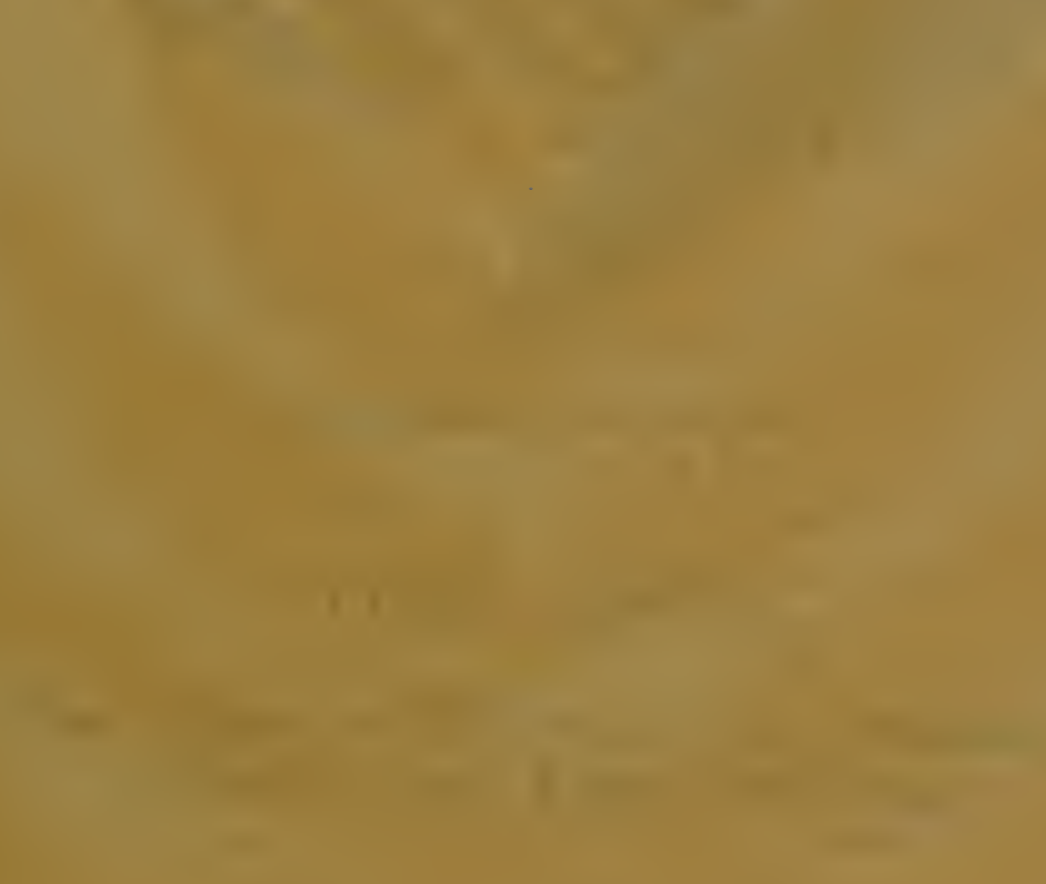

$$
-1-1-1=
$$

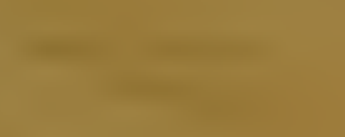

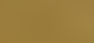

$x_{-1}=$
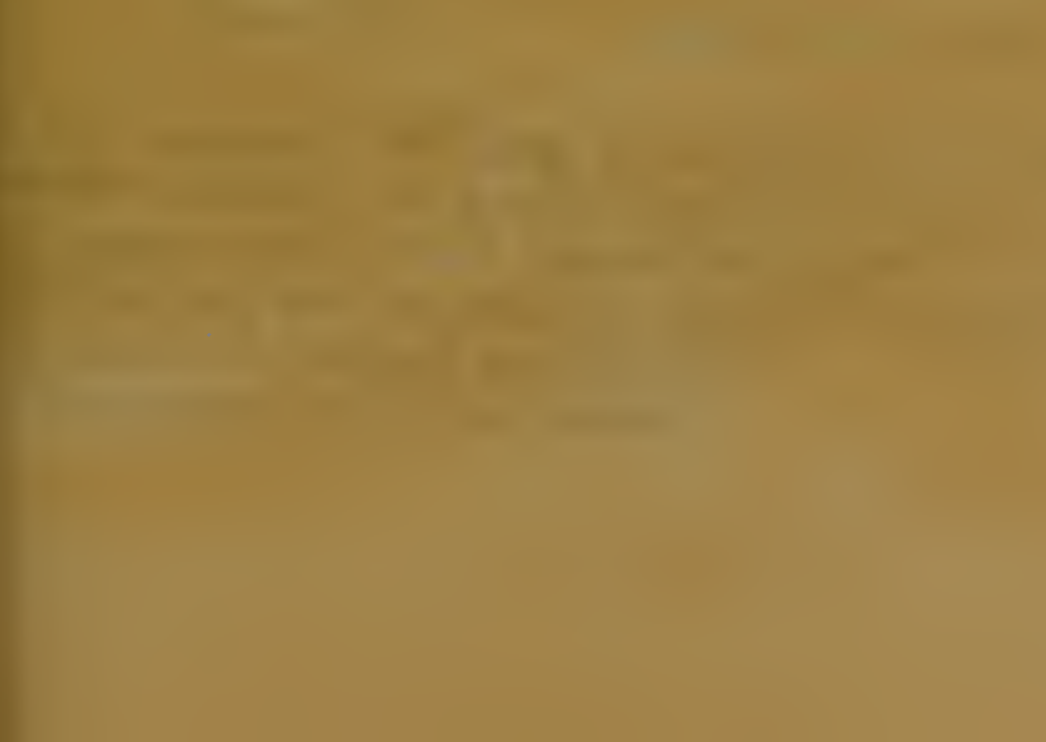

$5=$

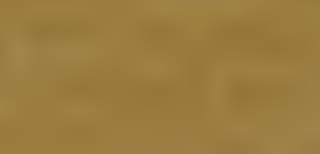




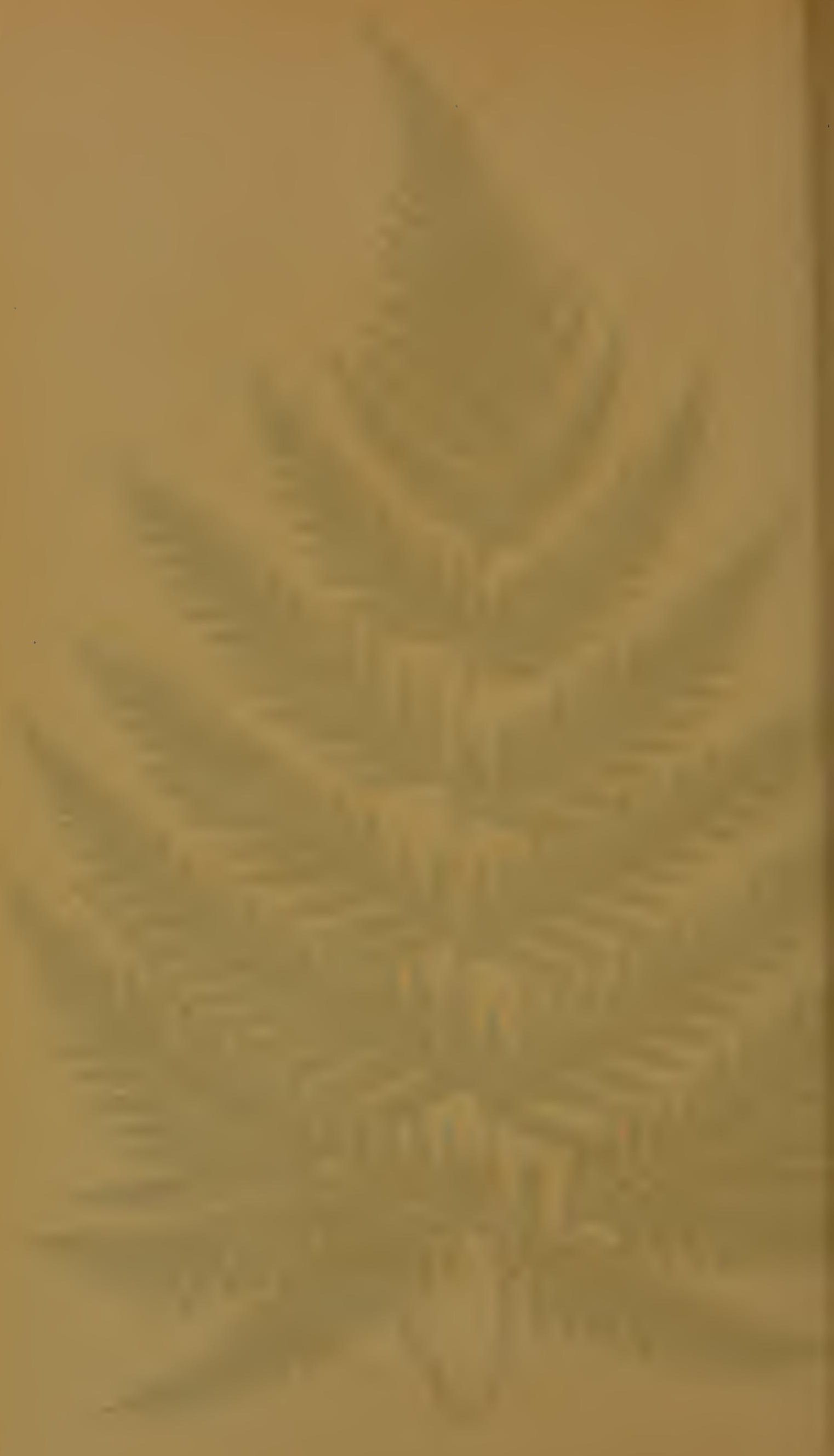




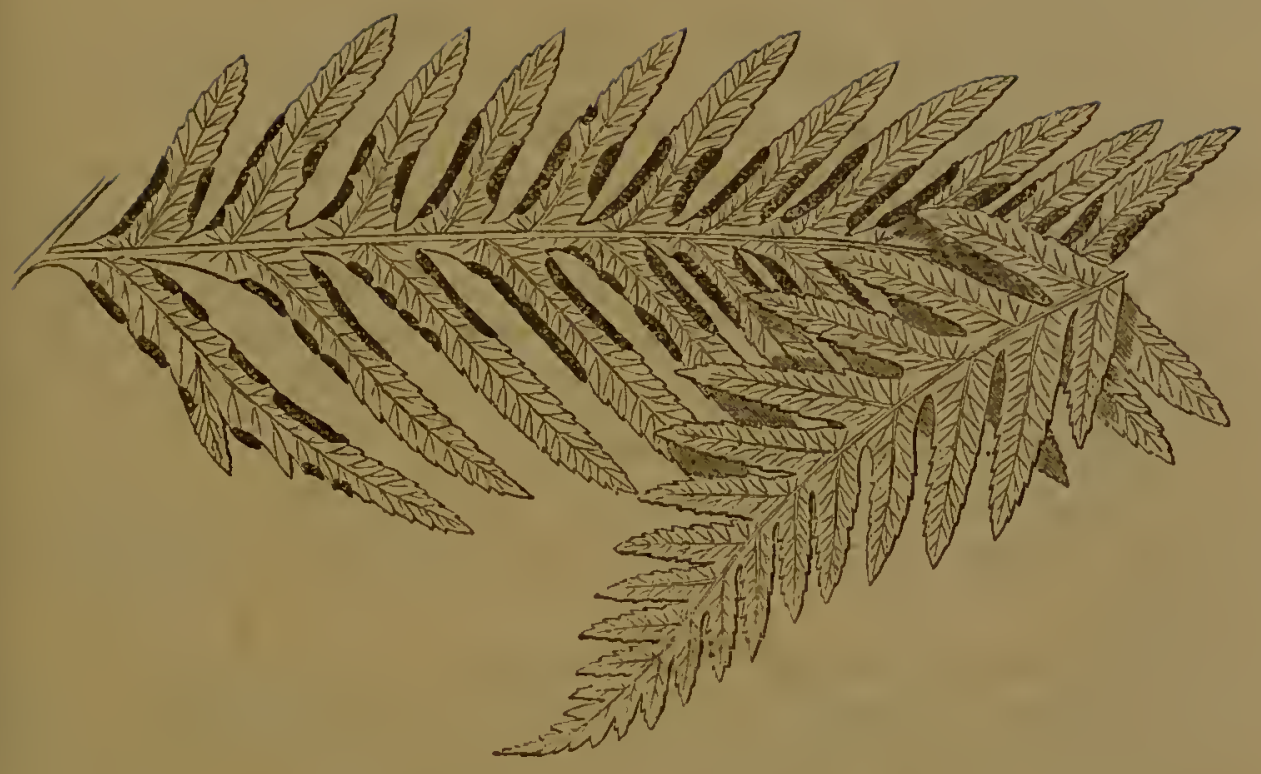

Portion of mature Frond-under sicle.

PTERIS ARGUTA.

Vahl. Moore and Houlston. Fee. Willdenow. J. Sirthr. Link. Kunze, (not Aiton.)

PISTE XLI. VOT. III.

Pteris palustris,

" incomplcta,

Pteris-Brake.
Porret. Willdenow:

Cavayitides.

Arguta-Sharp-notcled.

As interesting, tall-growing, naked-stemmed species, very readily cultivated, and specdily propagated by spores. In order to produce proper sizcd charactcristic fronds, it is neccssary that the plant have abundance of pot-room. A common spccics in most of our English grecnhouses.

An evergrecn grecnhouse species. 
From the isliuds of Madeira, St. Melena, the Canaries, Azores, and Portugal.

Introduced into the Royal Gardcns, Kicw, in the ycar $17 i 8$. The fronds are glabrous, spreading, somcwhat deltoid, chartaccous, bitripinnatc. Pinnules lincar-acuminate, with lincaroblong segments, which are obtuse, and having a dentate margin.

Stipes usually about half the length of the frond. Both stipes and rachis of a shining greenish brown colour, with two blackish narrow bands. Terminal adherent to an crect rhizoma. Stipes having few long hair-like scales. In a section the stipes is rounded beneath and fluted above.

Length of frond from three to five fect; colour pale gresn. In my spccimens, in fronds five feet in length threc fect are naked.

Sori lincar, extending from the base to nearly the apex of the pinnules, and half way down the decurrent portions. V cins well secn, being much palcr in colour than that of the frond.

My thanks arc due to Sir Oswald Mosley, Bart., of Rollestor Hall; Mr. Lamb, gardener to F. Wright, Esq., of Osmaston Manor, near Ashbourn; and to Mr. Sim, of Foot's Cray, for plants of P. arguta; and to Mr. Norman, of Hull, for fronds. It is in the Catalogues of Messrs. Sim, of Foot's Cray; Teitch, Jun., of Chelsca; Parker, of Holloway; Kinnedy, of Covent Garden; Booth, of Hamburg; and Cooling, of Derby.

The mature fronds are too large to figurc entirc: the illustration is from a young plant in my own collection. 



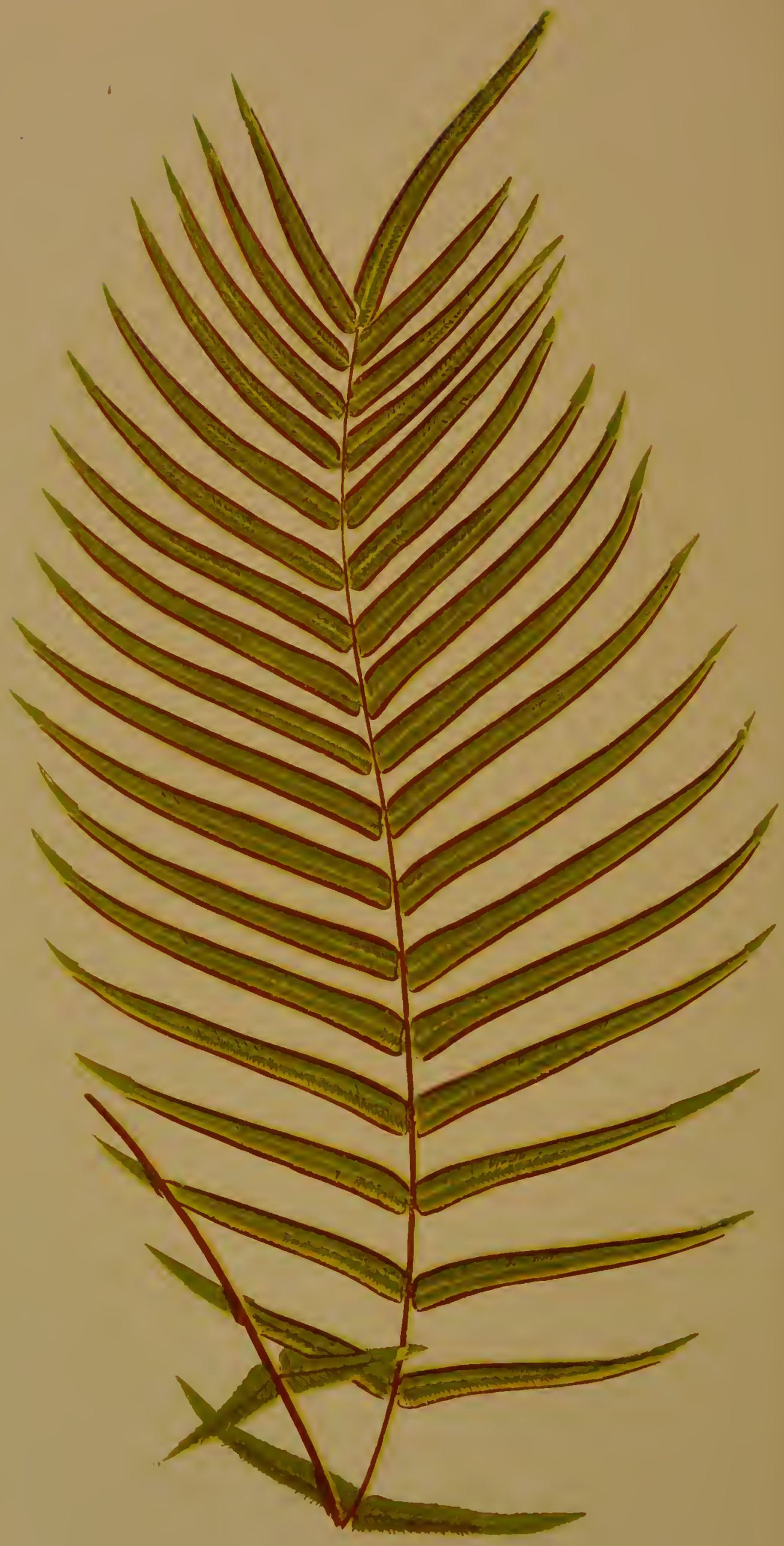




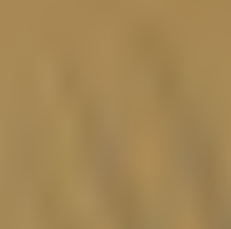

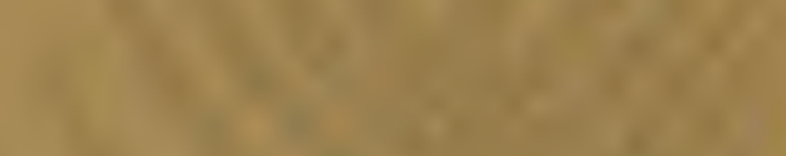

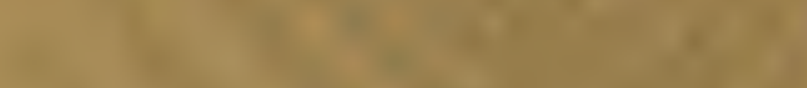

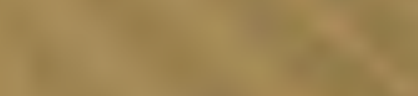

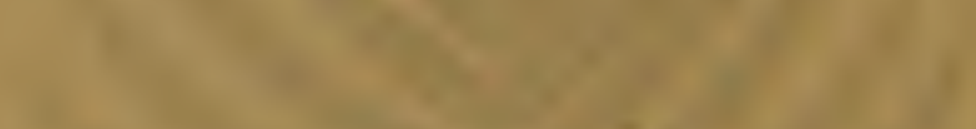

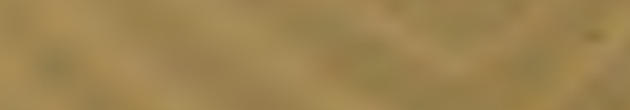

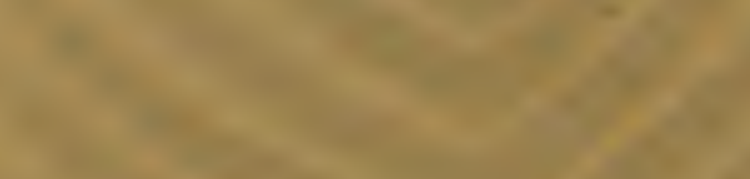

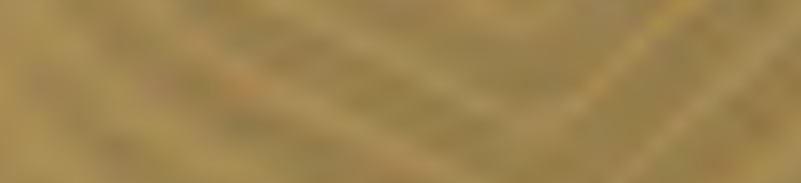

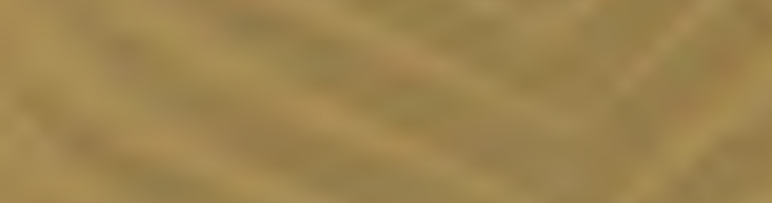
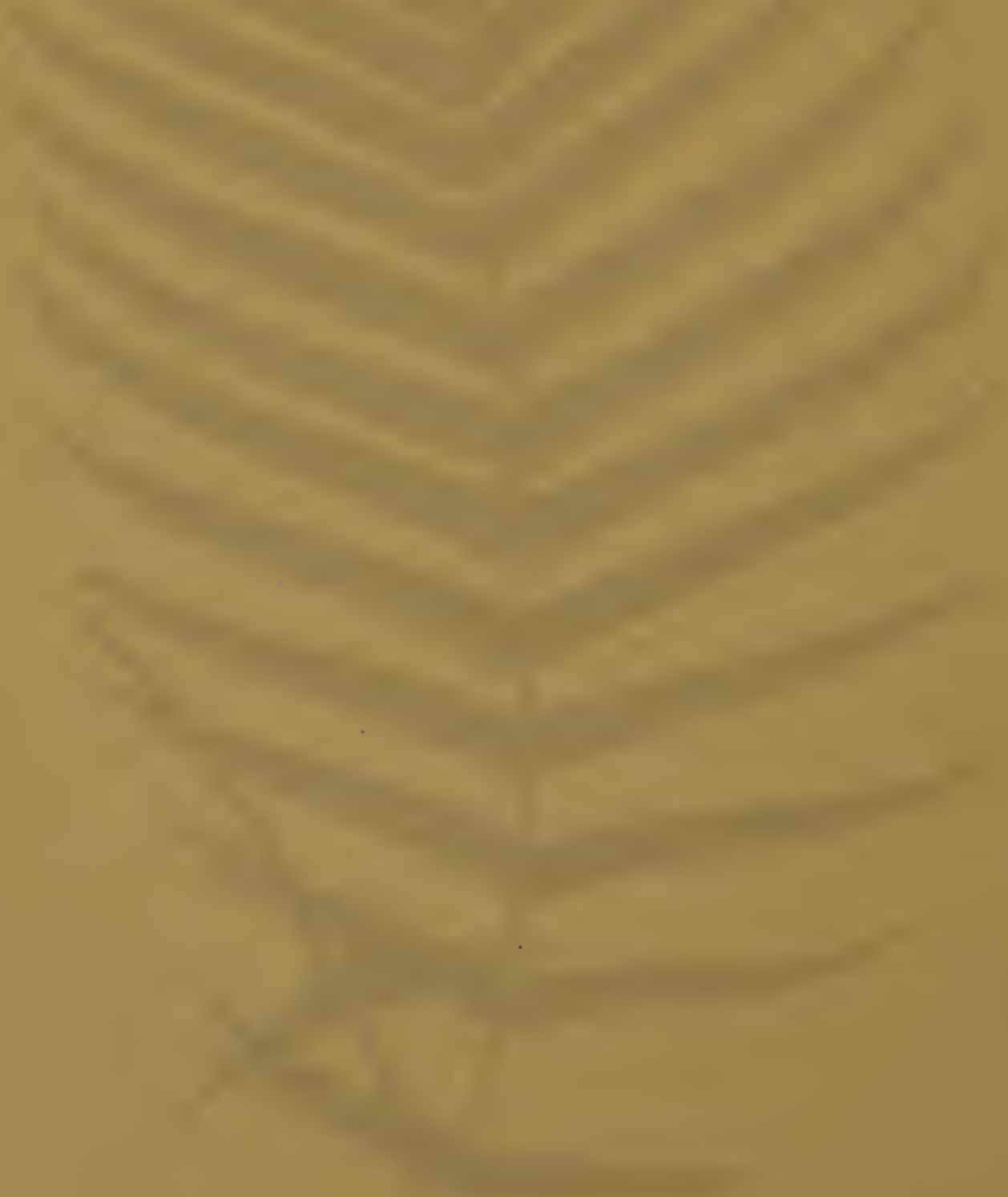
Dimnt of mature Frond-under sitle.

\section{P'TERIS LONGIFOLIA.}

\section{Linneus. Moore and Houlston. Fee. Smith. Kaulfuss. Willdenow. Link. \\ Schkuhr. Jacquin. Agardi. Kunze. Presl. ScIIOTT, MS.}

PLATE XLII. VOOL. III.

Pteris vittula,

Filix latifolia,

Pteris."ensifolia,

" costata,

Pteris-Brake.
Schkuhr, (not Bory.) Willdenow. Plumier.

Swartz.

Bort. Link.

I'He Pteris longifolia of Linnaus is a well-known specics in our gardens, easily propagated, rery distinet in its general form, and requiring but little care in its eultivation, and wherever grown a favourite. Its long pubcscence, standing out round the stipes, gives the plant a somewhat hedgehog look.

An crergreen stove Fern.

Native of Nepal, the Philippine Islands, tle W'est Indics, Janaica, and Manilla.

Introdueed into England in the year 1770 .

'I'he fronds, whieh are broadly lanecolate in form, are pinnate, the pinna being lincar, narrow, and as much as seren inches in length, petiolate, with the base amiculate. Fironds 
terminal, adherent to a creeping rhizoma. Stcrile pinna having a serrate margin.

Stipes crowded with long narrow pale-coloured scales; rachis - also with scales.

Sori continuous, and intermingled with hairs. Indusium plane.

Length of frond from two feet to two fect and a half; colour a dull heavy green.

For plants of this speeies I am indebted to $M r$. Stratton, of the Cambridge Botanie Garden; Messrs. Rollisson, of Tooting; and to Mr. Haythorn, gardener to Lord Niddleton, of Wollaton Hall; and for fronds to M. Schott, the Direetor of the Imperial Gardens, Vienna.

It is in the following Catalogues:-Messrs. Rollisson, of Tooting; Veitch, of Exeter; Veitch, Jun., of Chelsea; Sim, of Foot's Cray; A. Henderson, of Pine-apple Place; Parker, of Holloway; Booth, of Hamburg; Kennedy, of Covent Garden; Cooling, of Derby; and Stansficld and Son, of Todmorden.

The illustration is from a plant in my own collection. 


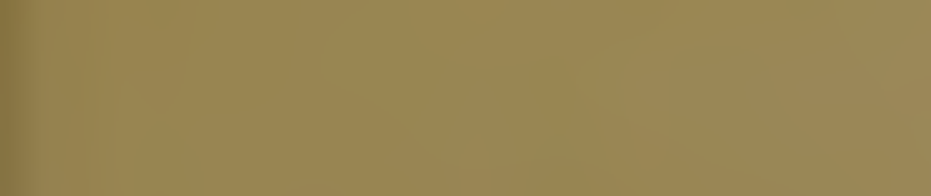

\section{.}




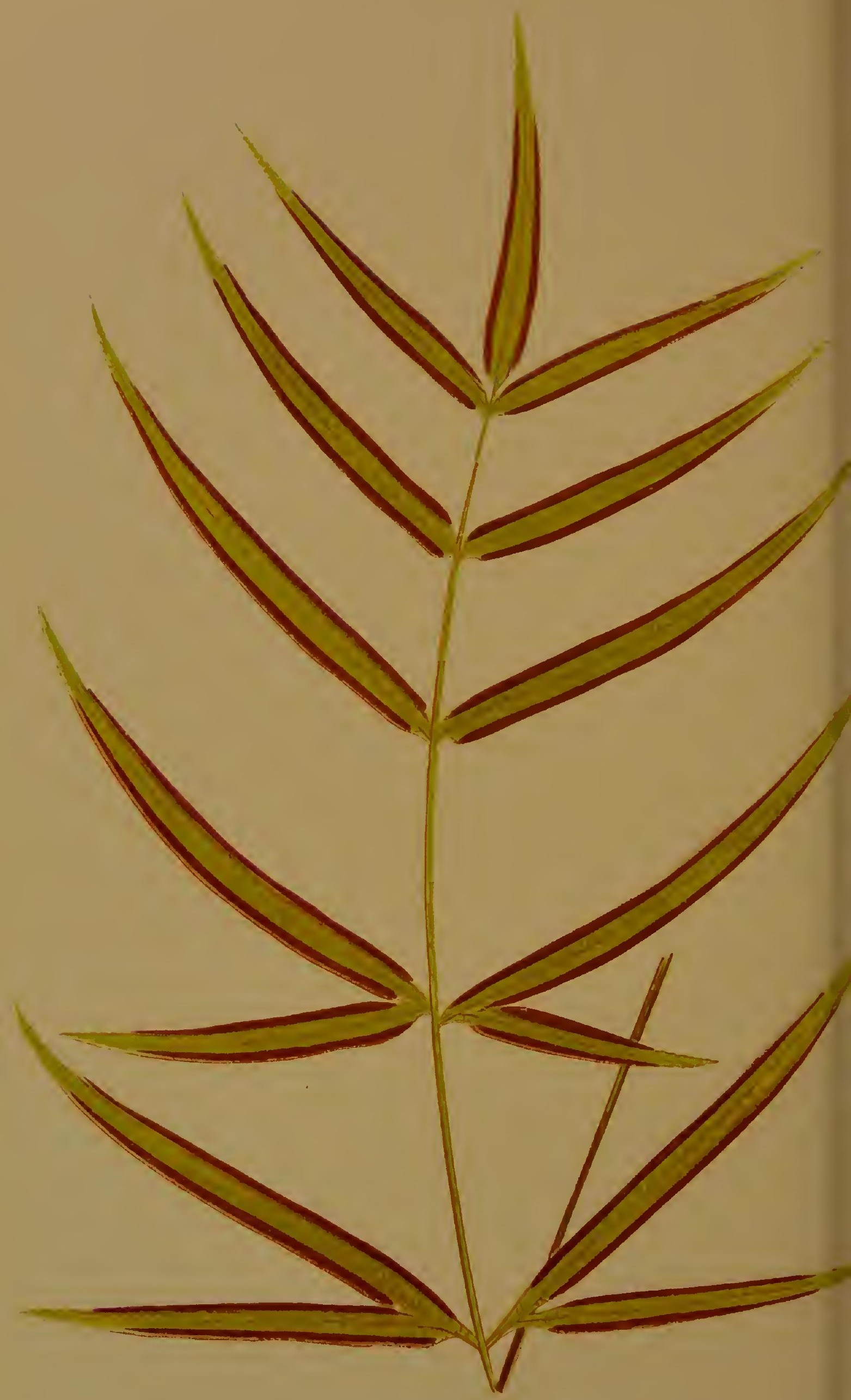




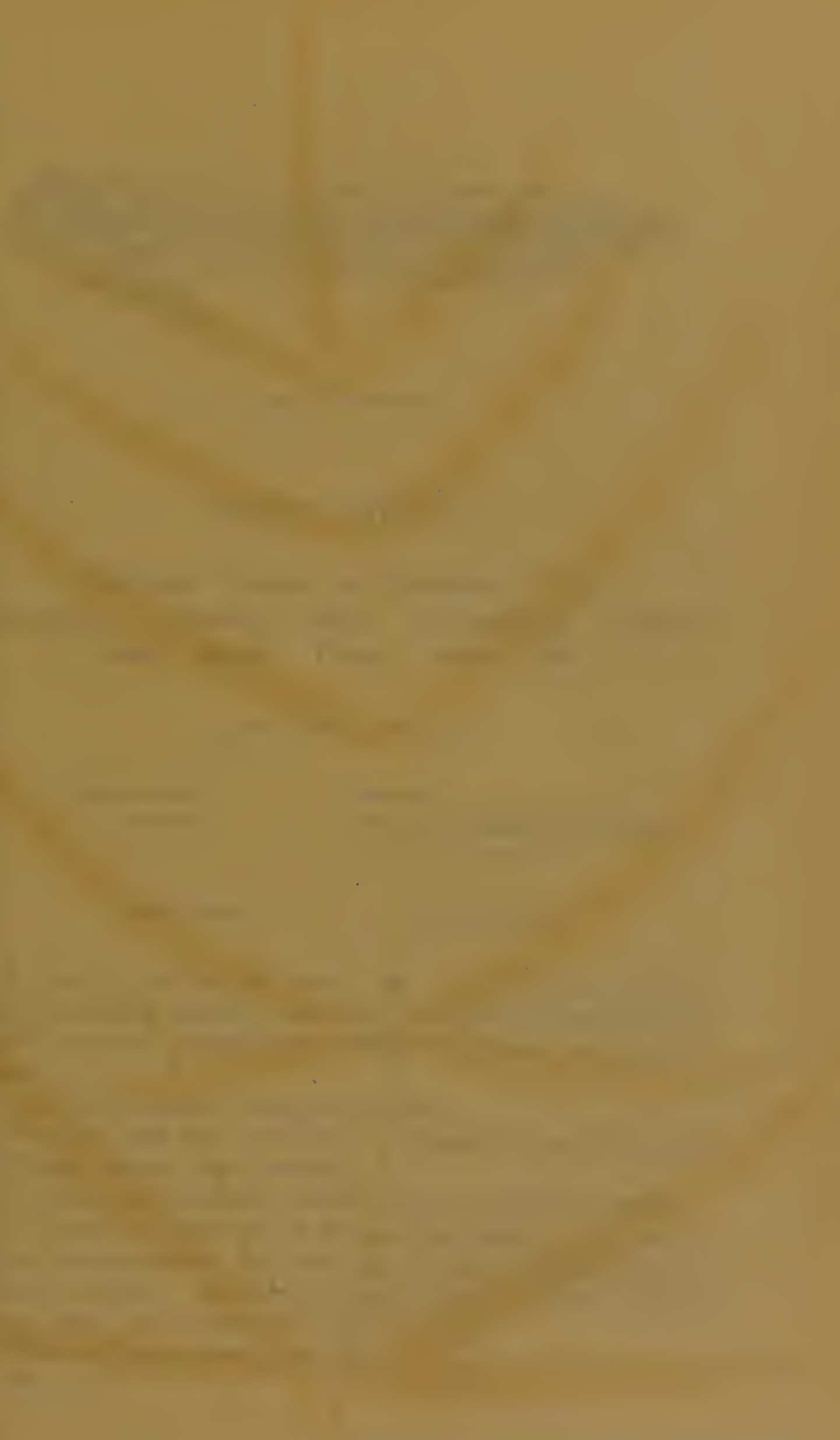





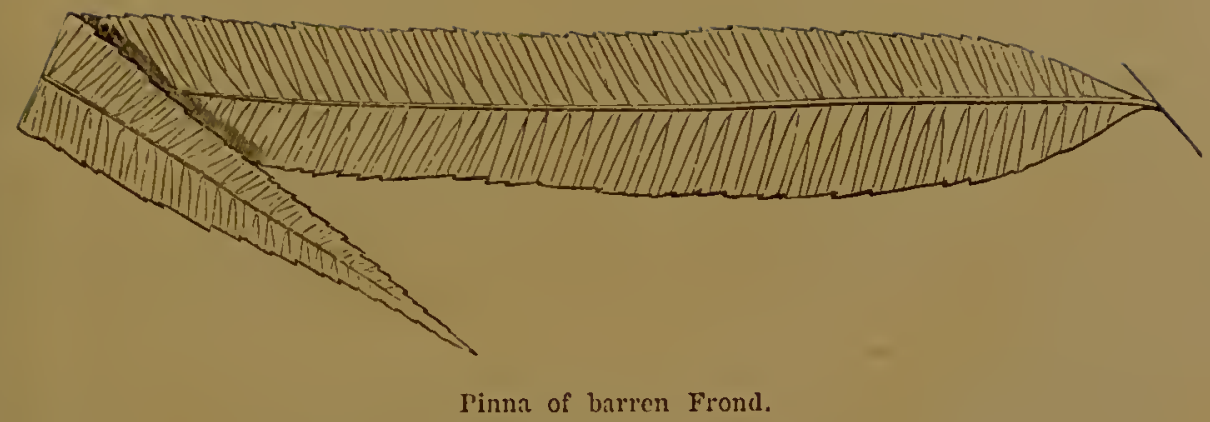

\section{PTERIS CRETICA.}

Linneus. Moore and Houlston. Fee. Tournefort. Schkuir. Sirter. Willidenow. Agardi. Link. Kunze. Presl. Schott, MS.

PI.ATE XIIII. VOI. III.

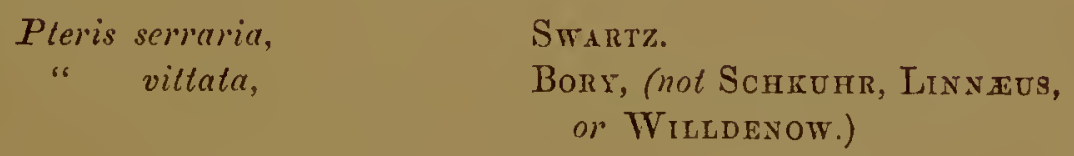

Pteris-Brake. $\quad$ Cretica-Cretan.

A pRETTY, and at the same time an uncommon, garden specics generally speaking, yet well worthy of extensive cultivation; compact in habit, and brilliant in colour; easily cultivated.

A warm grecnhouse evergrecn specics.

From the Fast and West Indies, Mexico, China, the south of Europe, Arabia, and Armenia.

Cultivated in the Royal Gardens, Kew, in the ycar 1820.

'The fronds are glabrous and pinnate, the pinnæe of the sterile fronds lincar-lanceolate, the lower pair bipartite, petiolulate, with a serrated margin. 'The fertilc segments lincar, narrow, serrated at the apex, and frequently six inches long.

Rachis and stipes straw-coloured.

VOL. III. 
Fronds lateral or terminal, adherent to a short creeping rhizoma.

Sori continuous and prominent.

Length of frond from twelve to eighteen inches; colour vivid pale green.

There is a variety from India called heterodactylon, which differs in the stipes and rachis being purplish brown in colour, the pinne being all bipartite, and the fronds arranged around a scaly crown.

My obligations are due to Mr. Sim, of Foot's Cray, for plants of Pteris cretica; and to M. Schott, Director of the Imperial Gardens, Vienna, for fronds.

It may be procured of Messrs. Sim, of Foot's Cray; Rollisson, of Tooting; A. Henderson, of Pine-apple Place; Booth, of Hamburg; Kennedy, of Covent Garden; and Stansfield and Son, Todmorden.

The illustration is from a plant in my own collection. 


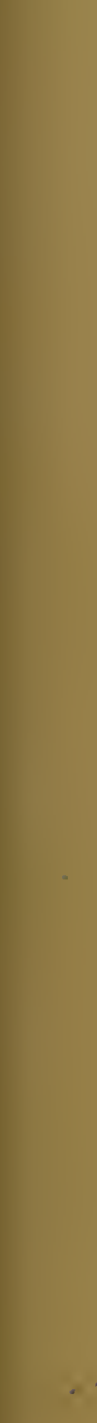




$$
\text { mingention }
$$

(i) $D$,

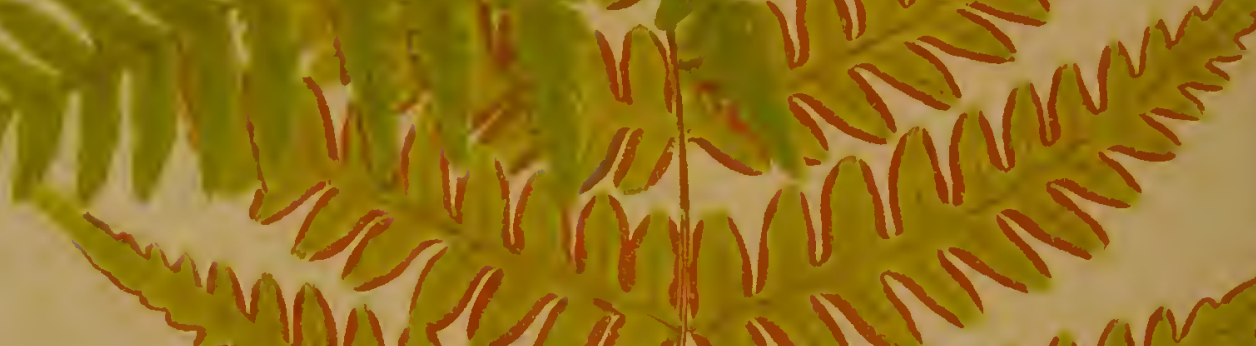
Enmir zan NNANO commonming

- mammma fuININ rivivis monnas zimpman

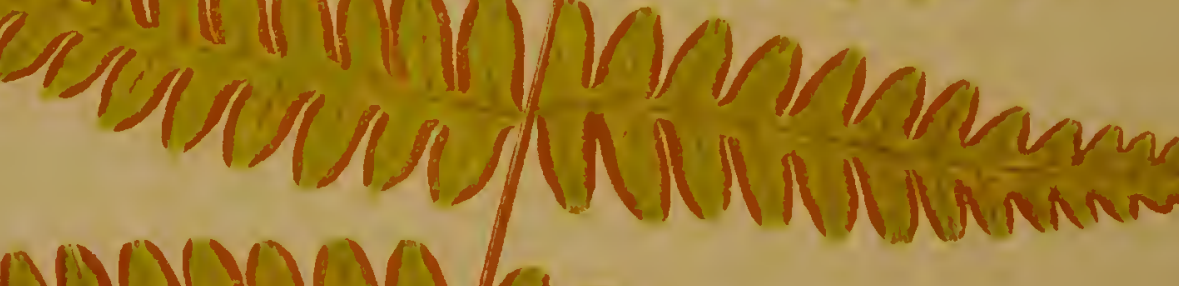

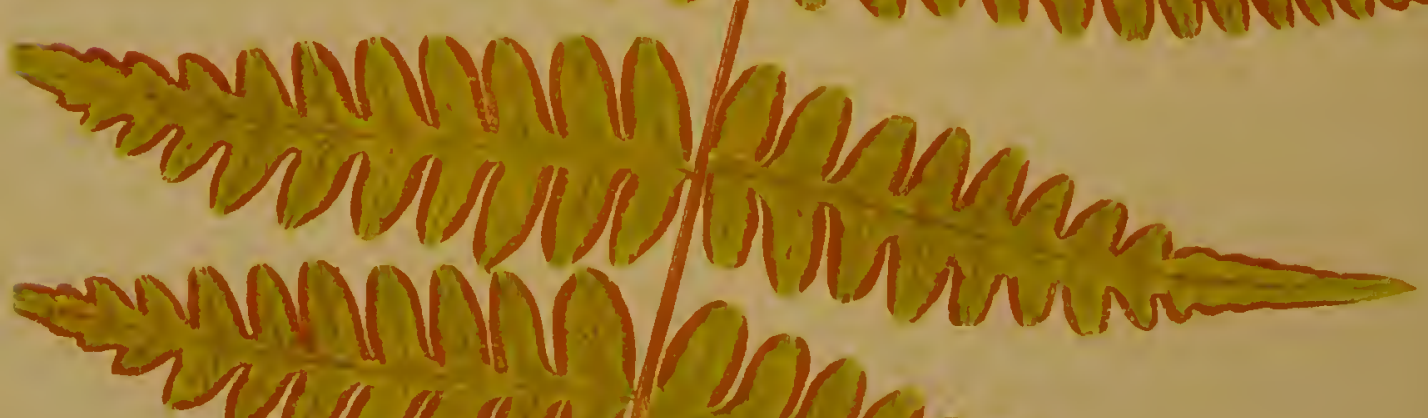
ENMMMM Gra 



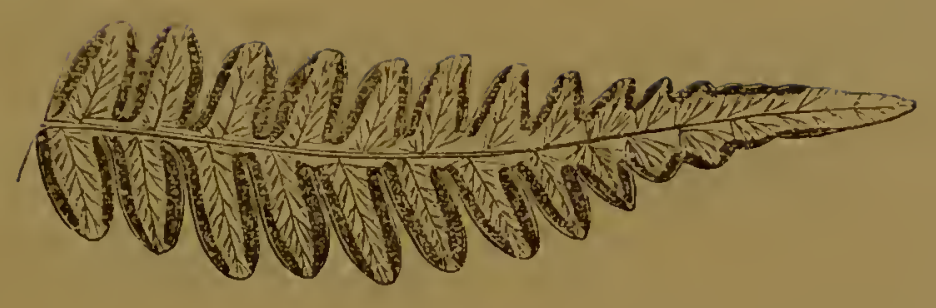

Portion of nuture rroud-under side.

\section{PTERIS VESPERTILIONIS.}

\section{Labillardiere. Kunze. Schott, MS.}

PLATE XIIV. VOL. HI.

Litobrochia vespertilionis,

6

6

Pteris-Brake.

In the Section Litobrochia of Authors.

'Tus present speeies is an exeeedingly handsome, glaueouslooking Osmunda-like Fern, which should be in every colleetion. When room is allowed for it to grow properly, it makes an attractive-looking speeimen.

An cvergreen greenlouse Fern.

Native of New Holland and New Zealand.

Raised at the Royal Gurdens, Kew, in the year 1838.

The fronds are glabrous, widest at the base and gradually narrowing to a point; tripinnate; pinnæ lanceolate, opposite; pinnules opposite, sessile, oblong-linear, acuminate, the segments bcing membranous, roundish, oblong-obtuse; deeurrent at the base.

Rachis and stipes glaucous, at first green, then purplish green; base scaly, lateral, attached to a crecping, dirk brown, sealy 
rhizoma. Scales reddish brown. Stipes nine inches in length.

Sori oblong-linear, on either side pinnules and segments, but not extending to the apex of cither; colour pale orange brown.

Length of frond from two to three fcet; colour above yellowish green, underneath glaucous.

I am indebted to Mr. J. Henderson, of Wentworth, for a plant of this speeies; and to Mr. Roper, of Brighton; Mr. Downs, of Ilfracombe; Mr. Norman, of IIull; and to M. Schott, Director of the Imperial Gardens, Yienna, for fronds.

It is in the Catalogues of Messrs. Rollisson, of 'looting; Parker, of Holloway; Masters, of Canterbury; $\Lambda$. Menderson, of Pine-apple Place; R. Sim, of Foot's Cray; Kennedy, of Covent Garden; and Stansfield and Son, of 'Jodmorden.

The illustration is a portion of a frond from a plant in my own collection.

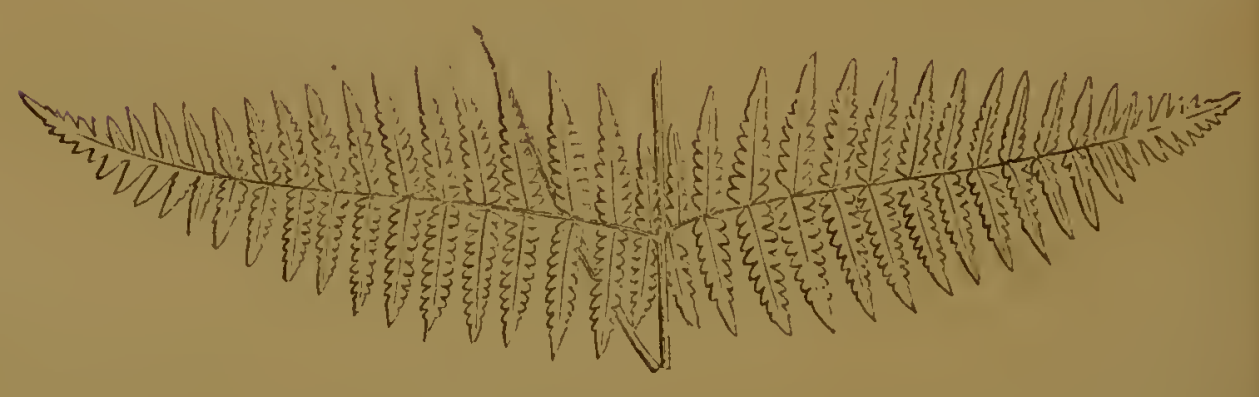





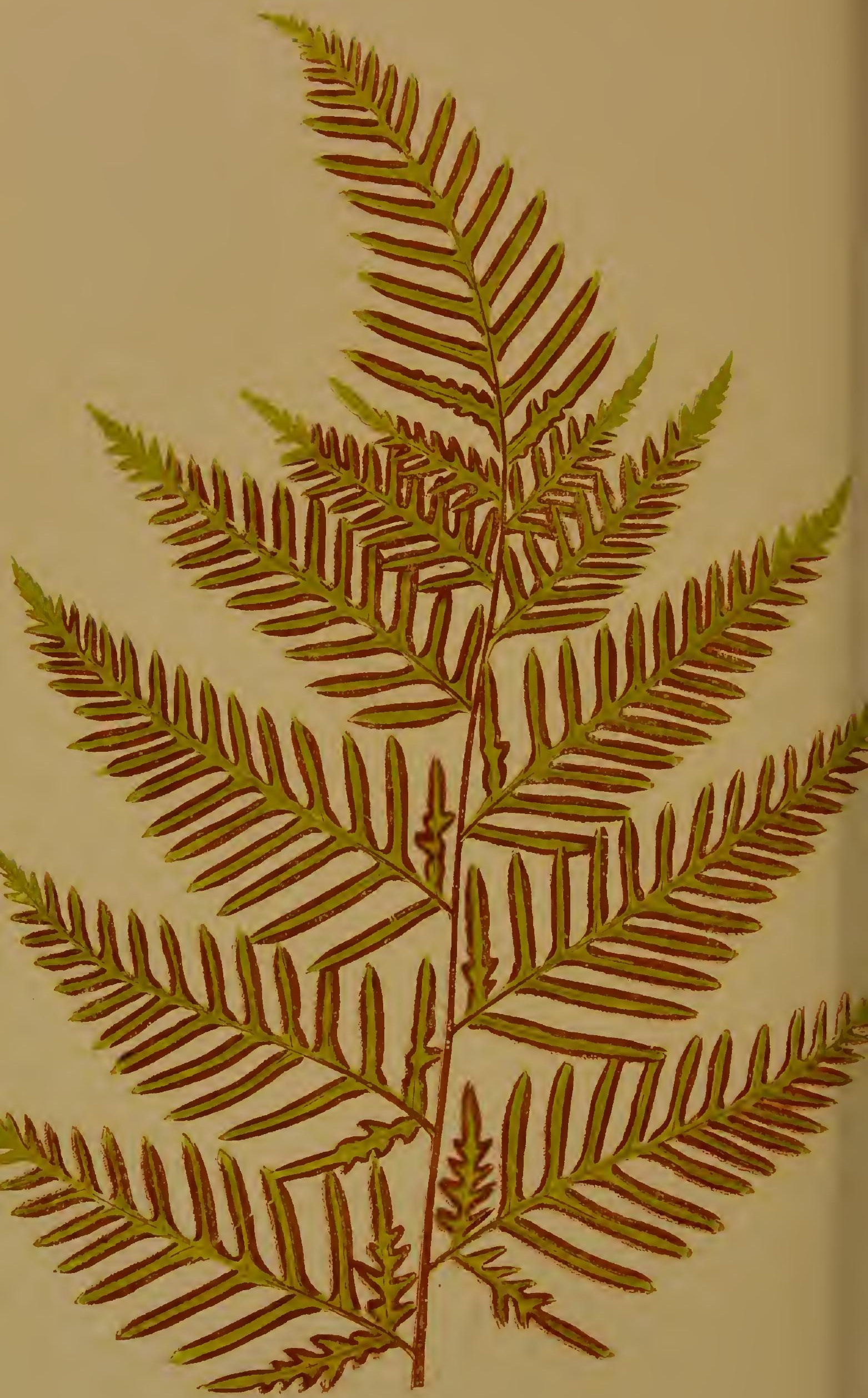





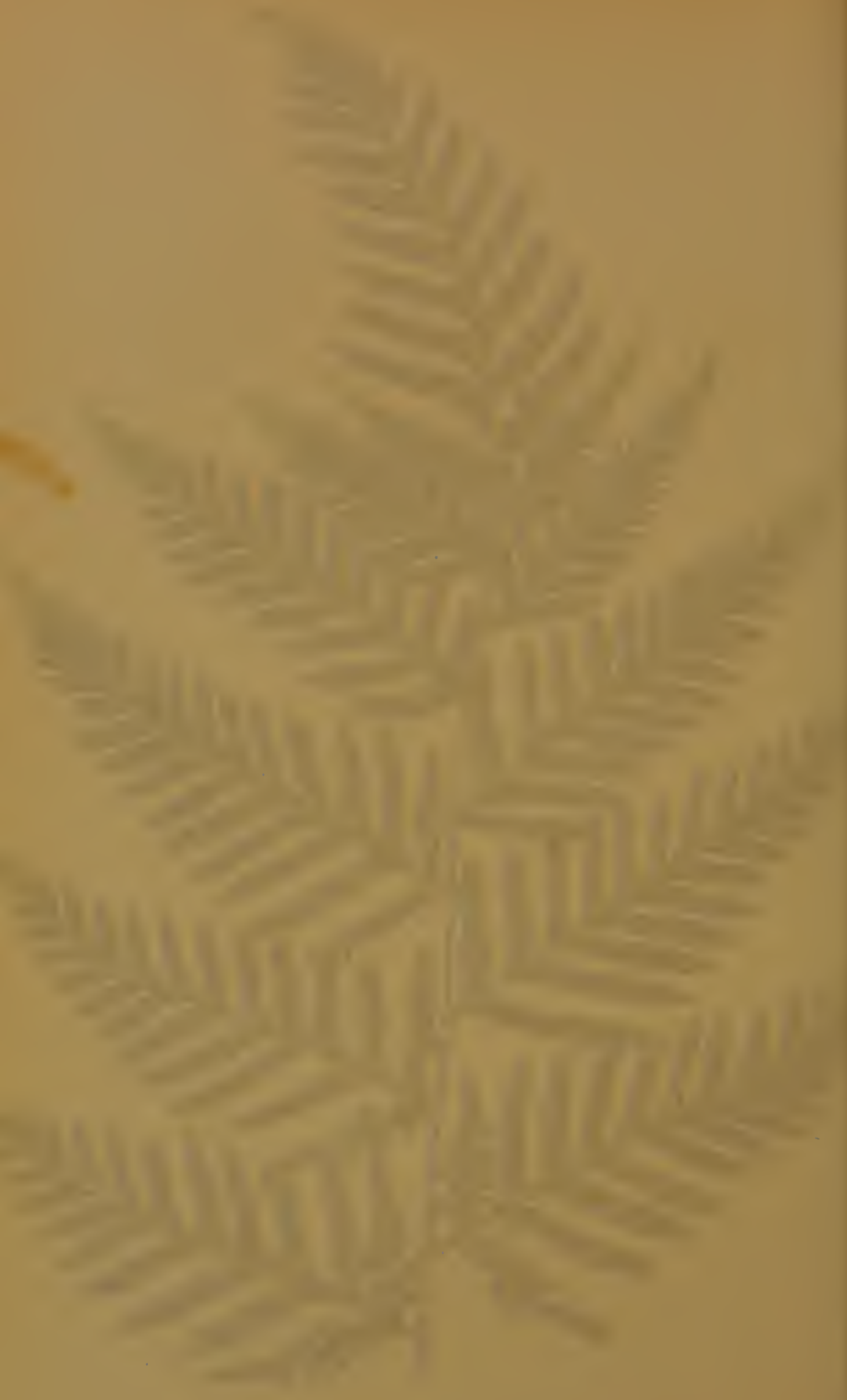




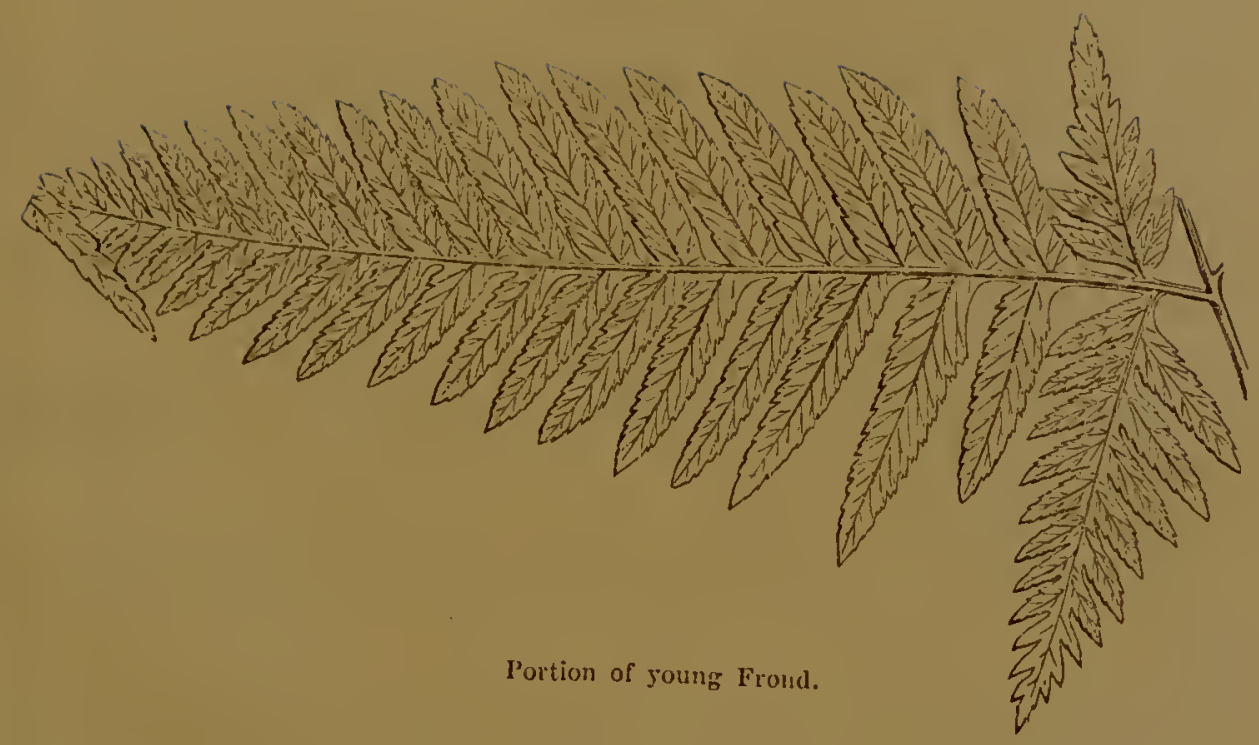

\title{
PTERIS TREMULA.
}

\section{R. Brown. Moore and Houlston. Fee. Kunze. PresL. J. SMith.}

PLATE XIV. VOL. III.

\author{
Pleris chrysocarpa, \\ Livk. Schotr, MS., \\ " "ffinis,

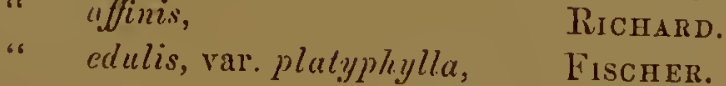 \\ (not of Hooker \& Greville.)

$$
\text { Pteris-Brake. Tromulu-Trembling. }
$$

'l'nis abundant species, handsome as it is, becomes a pest in our collections; young plants spring up in all the pots, and increase so rapidly in size, that unless they are destroyed would soon monopolize a whole house to themsclves. No ferns grow so frecly from spores as Pteris tremula, P. scrrulata, Iypolepis repens, and Nephrodium molle. In a collection of sercral 
hundred species, ninety per cent of seedling Ferns will be found to be of the above-mentioned species.

An evergreen greenliouse Fern.

Native of New South Wales, New Holland, Nepal, and New Zealand.

Fronds glabrous, slender, and deltoid; tri-quadripinnate; the pinnules linear, caudate at the apex; narrow linear-oblong segments, margin erenatc, apex blunt.

Stipes one half the length of the frond, green when young, afterwards reddish brown; terminal, adhering to a somewhat creeping rhizoma.

Length of frond three feet; colour bright green.

Veins distinctly seen, being paler in colour than that of the frolld.

Sori linear, eontinuous to the apex of the pinnules, where they frequently join; eolour reddish brown, and prominent. Oeeasionally fronds will be found with interrupted sori.

My thanks are due to Sir Oswald Musley, Bart., of Rolleston Hall; M. Sehott, Director of the Imperial Gardens, Vienna; Mr. Lamb, gardener to F. Wright, Esq., of Osinaston Manor; and to Mr. Sim, of Foot's Cray, for plants of this speeies.

It is in the Catalogues of Messrs. Rollisson, of Tooting; Parker, of Holloway; A. Henderson, of Pine-apple Place; Vcitel, Jun., of Chelsea; R. Sim, of Foot's Cray; Bootll, of Hamburg; Cooling, of Derby; Kennedy, of Covent Garden; and Stansfield and Son, of Todmorden.

The illustration is a portion of a frond from a plant in my own eollection. 



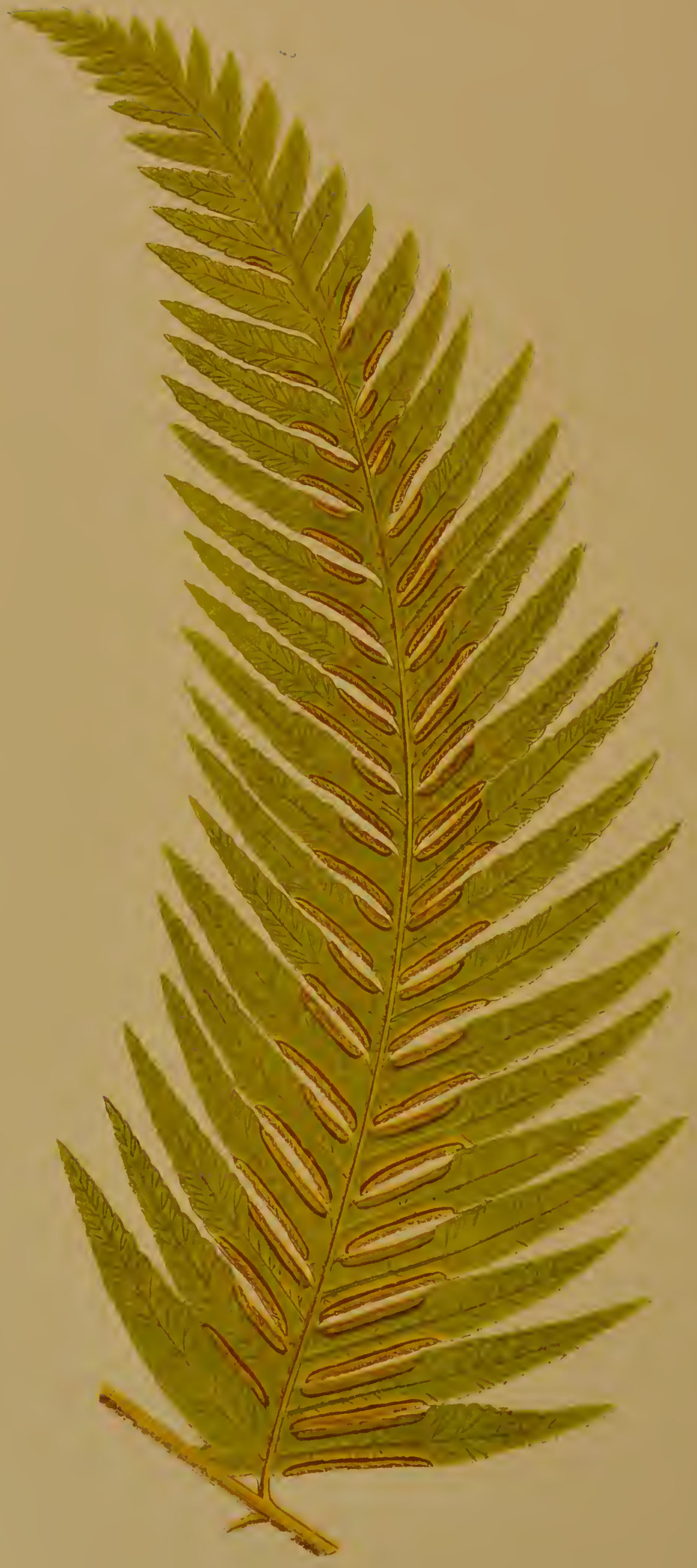





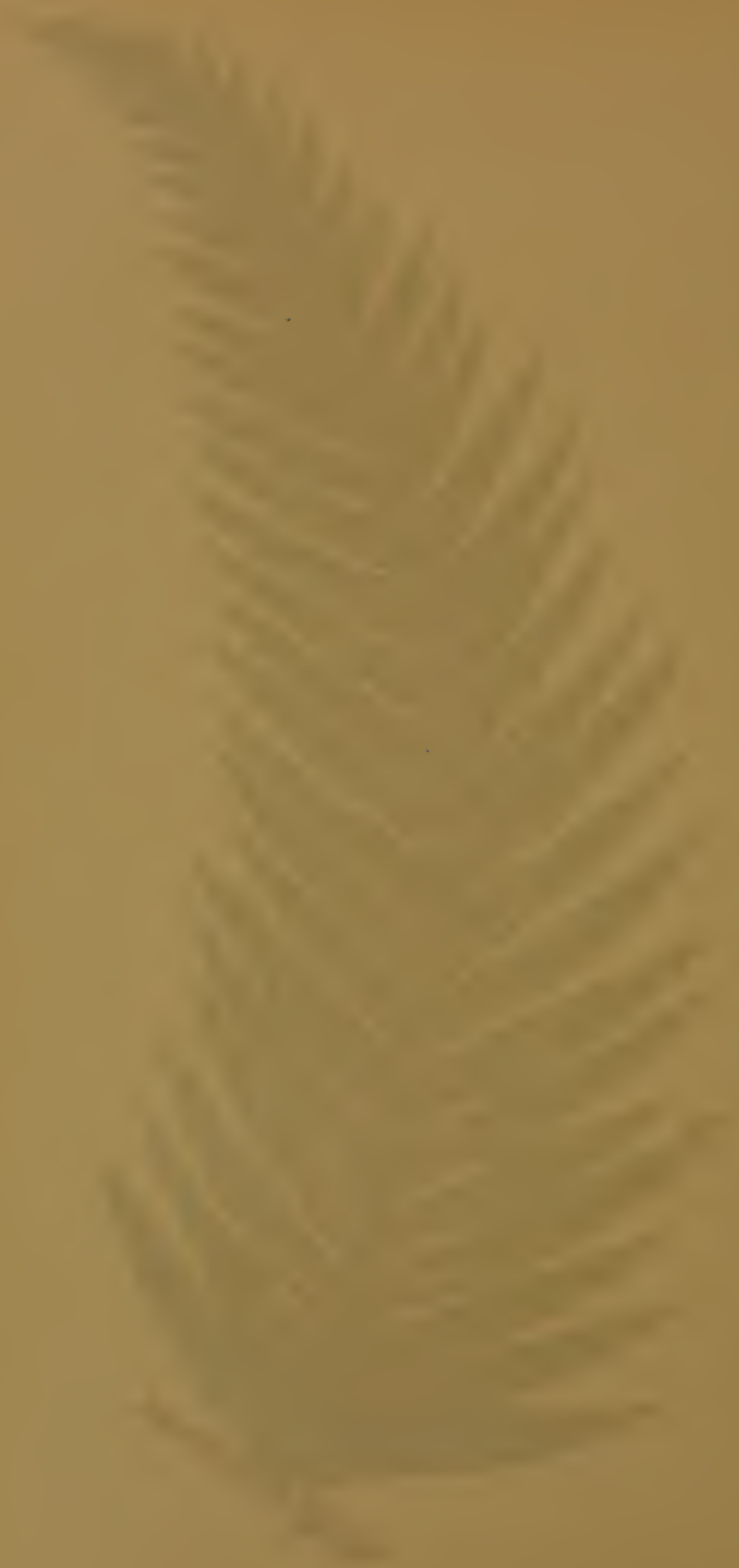




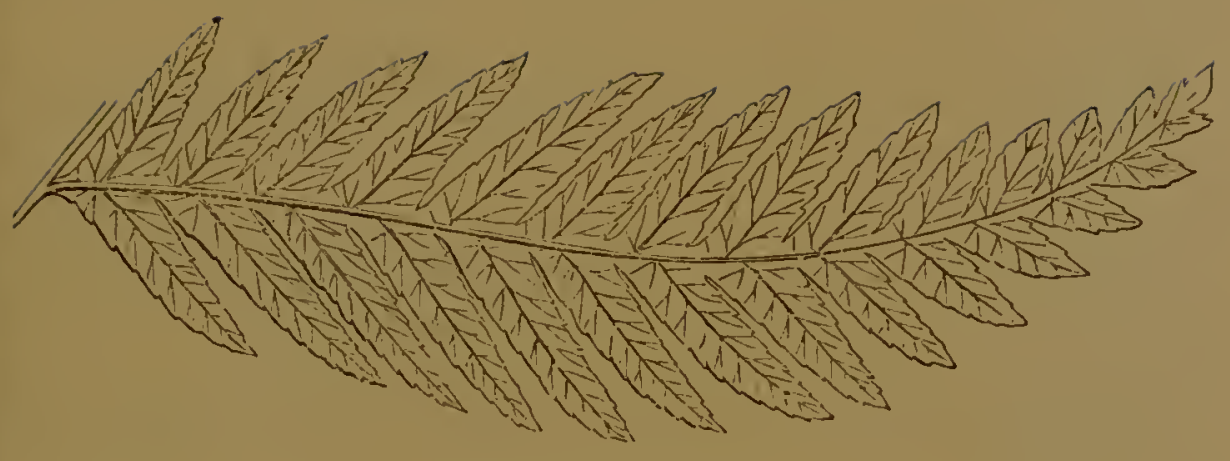

Portion of barrez Frond.

\section{PTERIS KINGIANA.}

Endicher. Moore and Houlston. Fee. Jacquin. J. Sutrit. Kunze. P'rest.

I'ITE XIVI. VOJ. III.

Pteris-Brake. Tingiana-Kingrs.

A LARGr, noblc-looking, vigorous-growing, spreading, and somcwhat pendulous-labited Fern, requiring abundance of potroom and a strong soil to support its thick fleshy-feeling fronds.

An evergreen grecnhousc spccies.

From Norfolk Island.

Introdueed into the Royal Gardens, Kew, in the ycar 1831, by Mr. Allan Cunninghain.

Fronds glabrous, sub-bipinnate; pinnx lincar-lanccolate and drooping, lowcst pair bipartite and petiolulatc, segments lincaracuminate, repand, scrrate margin, costa spinulosc on the upper sidc; latcral, or tcrminal, attached to a short erecping rhizoma. Stipes twcnty inches in length, cireular, scaly near the base; vivid grcen in colour, exeept near the base, wherc brownish.

Sori continuous, commencing at the basc, yet not extending 
much above a third of the length of the pinnules; colour brown; indusium broad.

I.ength of frond three feet; colour yellowish green.

My thanks are duc to Mr. Henderson, of Wentworth, for a plant of this Forn.

It may be procured of Messrs. Sim, of Foot's Cray; Rollisson, of 'Tooting; A. Henderson, of Pinc-apple Place; Teitch, Jun., of Chelsea; Parker, of Holloway; Stansficld and Son, of Todmorden; and Kcmuedy, of Covent Garden.

The illustration is a portion of a frond from a plant in my own collection. 



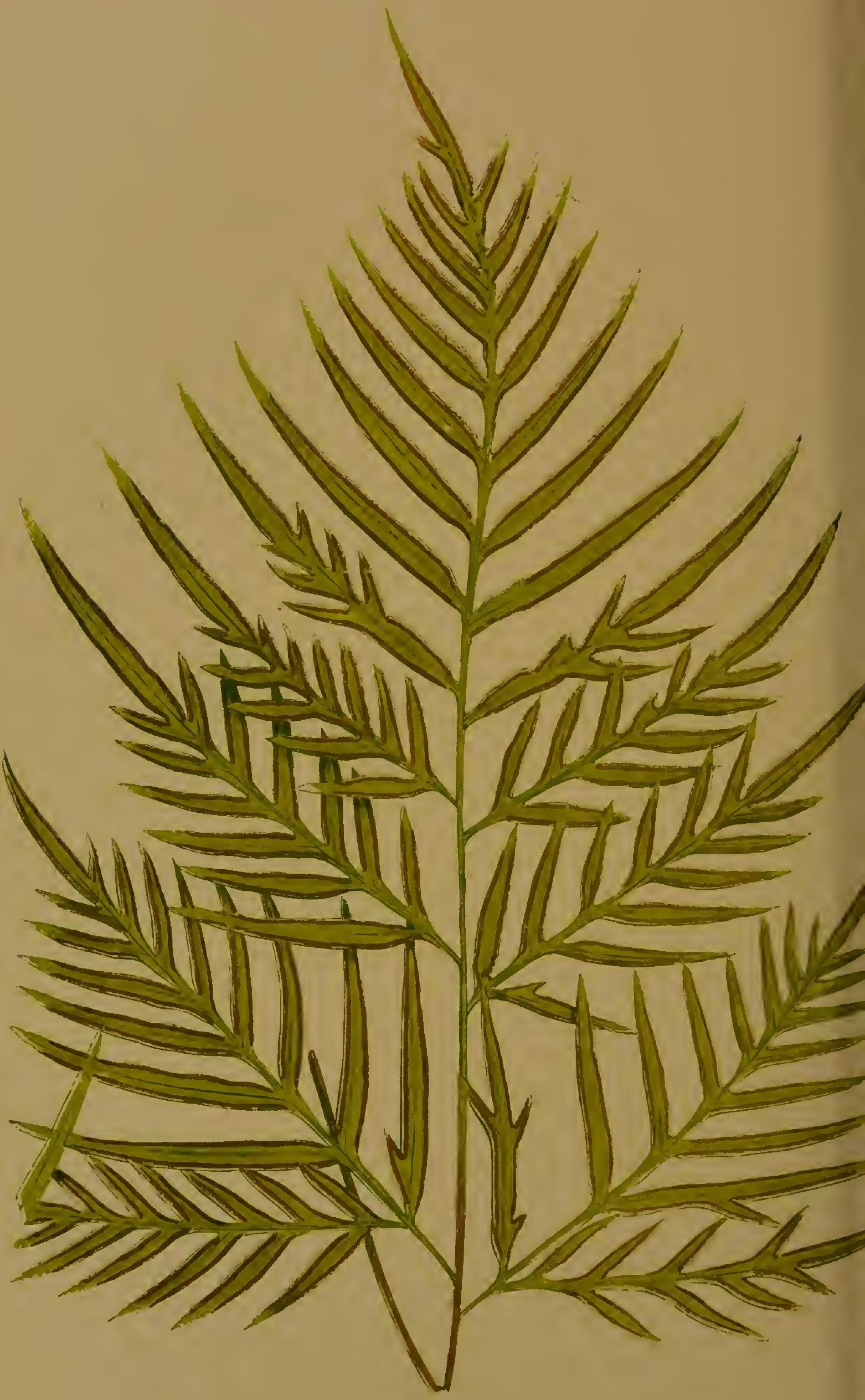




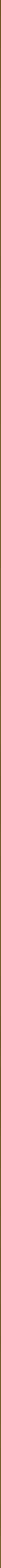




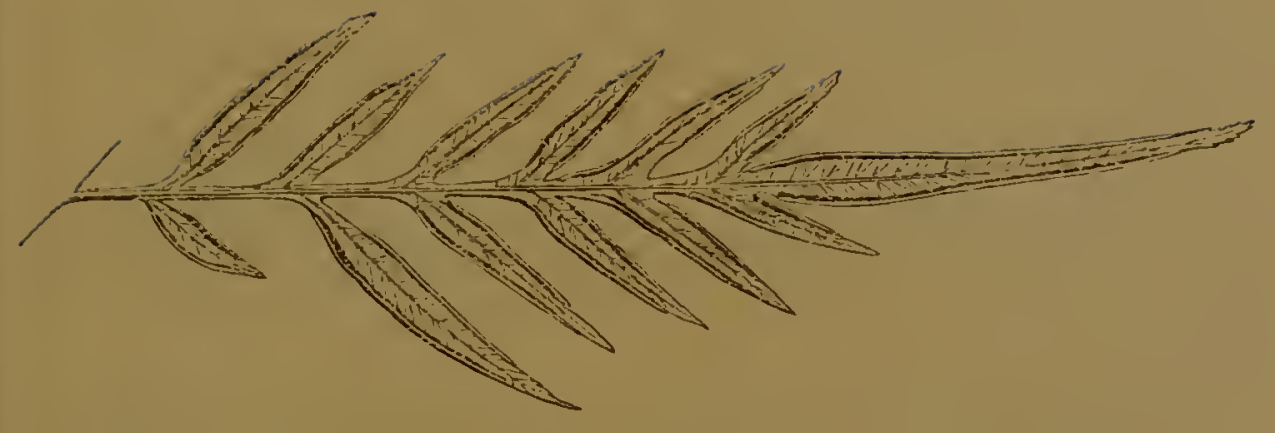

Portion of mature Frond-under side.

\section{. PTERIS LEPTOPHYLLA.}

Swartz. Kunze. Link. Agardi. Presl.

PLATE XIJII. voL. III.

Litobrochia leptophylla,

Pteris spinulosa,

" decurrens,

Cheilanthes spinulosa,

Pteris-Brake.
J. Smith. Moore and Houlston.

Fee. Swartz.

RADDI. SchotT, MS.

ARRAB, (not of LINK or RADDI.)

Lisk.

Leptophylla-Slender-leared.

In the Section Litonrochia of Authors.

A DEL.icate, pleasing, dwarf species, whose spinulose fronds induced both Link and Raddi to name it spinulosa.

$\Lambda$ stove species.

Native of Brazil.

Raised at the Royal Gardens, Kew, in the year 1834.

Fertile froads glabrous, triangular in form, bitripinnate; segments distant, acuminate, linear, and narrow. Apex serrate.

Stcrile fronds glabrous, triangular in form, bipinnatifid, and bclow tripinnatifid; pinnre linear-acuminate, decurrent at the base; margin scrrate, with long spinulose treth.

VOI. III. 
Fronds terminal, adherent to it faseiculate rhizoma.

Sori linear, eontinuous almost to the apex.

Length of sterile frond twelve inehes; length of fertile frond two feet.

In a fertile frond tifteen inehes in length the stipes was nine inches, and in a barren frond of eight inehes, the stipes was five inches. Stipes green on the under side and rounded, flat on the upper, and brownish. Few seattered seales near the base.

My thanks are duc to M. Sehott, the Direetor of the Inperial Gardens of Vienna, and to Messis. E. G. Henderson, for plants of this species.

It is in the Fern Catalogues of Messrs. A. Henderson, of Pine-apple Plaee; E. G. Henderson, of St. John's Wood; Booth, of Hamburg; Kennedy, of Covent Garden; Parker, of Holloway; and Stansfield and Son, of Todmorden.

The illustration is from a plant in my own eollection. 



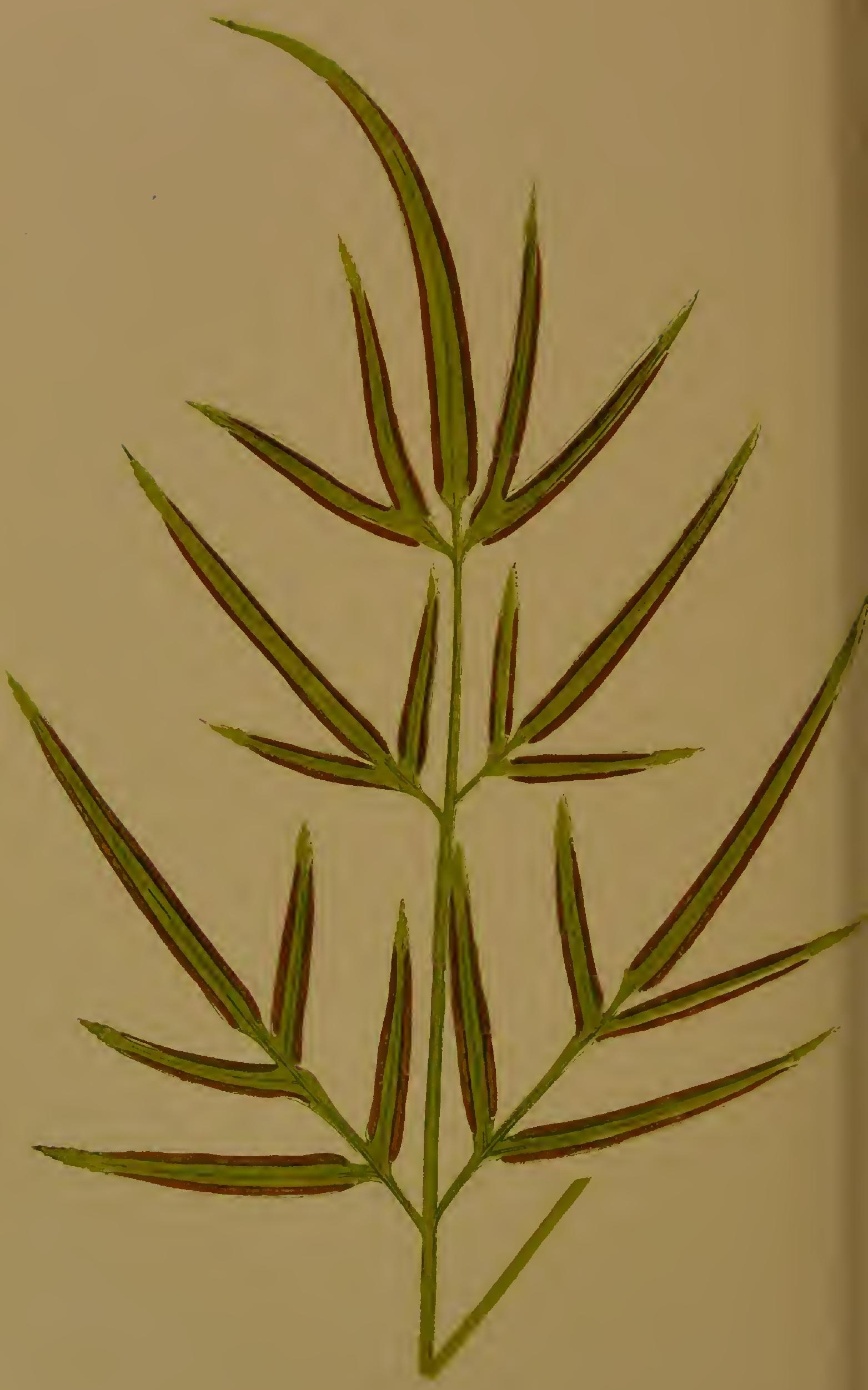




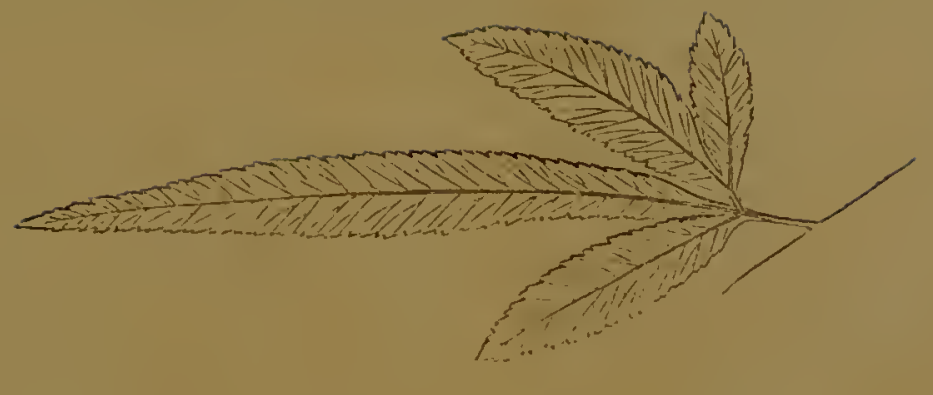

l'ortion of barren Frond.

\section{PTERIS CRENATA.}

Swartz. Moore and Houlston. J. Suitit. Fee. Burmann. Houttuys. Kunze. Schott, MS.

PIAATE XILIII. VOL. III.

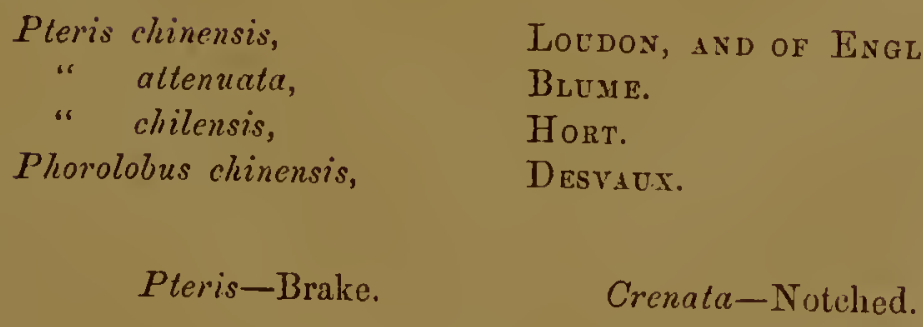

Loudon, and of English Gardens.

Pteris crenata is not a common species in our English gardens, although easily managed with the ordinary care of hothouse plants.

An evergreen stove Fern.

Native of the East Indics, China, Java, New Holland, and the Philippine Islands.

Cultivated at the Royal Gardens, Kcw, in 1822.

Fronds glabrous, bipinnatc. Sterile frond having the pinnules oblong-ovate in form, margin erenato-serrate, decurrent at the inferior base. Fertile frond crect, pinnules lincar-aeuminate, narrow, sub-pctiolate, and decurrent at the inferior base.

Fronds latcral, adherent to a short crecping rhizoma. 
Sori continuous, extending along the decurrent portions to the apex of the pinnules, and, although margined, never round the upper edges, being always on the under side. Indusium prickly.

Length of frond from twelve to eighteen inches; eolour dull grcen.

Stipes circular on the under side, and green; hollowed on the upper, and darker green. In a frond in my eollection, twenty inches in length, the stipes was nearly twelve inches.

My thanks are due to Mr. Stratton, of the Cambridge Botanic Gardens, and to Mr. Henderson, of Wentworth, for plants of this speeies; and to M. Schott, of the Imperial Gardens, Vienna, for fronds.

The following Nurserymen inelude it in their Catalogues:Messrs. Booth, of Hamburg; Sim, of Foot's Cray; Parker, of Holloway; Veitch, Jun., of Chelsea; A. Henderson, of Pineapple Place; Stansfield and Son, of Todmorden; and Kennedy, of Corent Garden.

The illustration is from a plant in my own collection. 






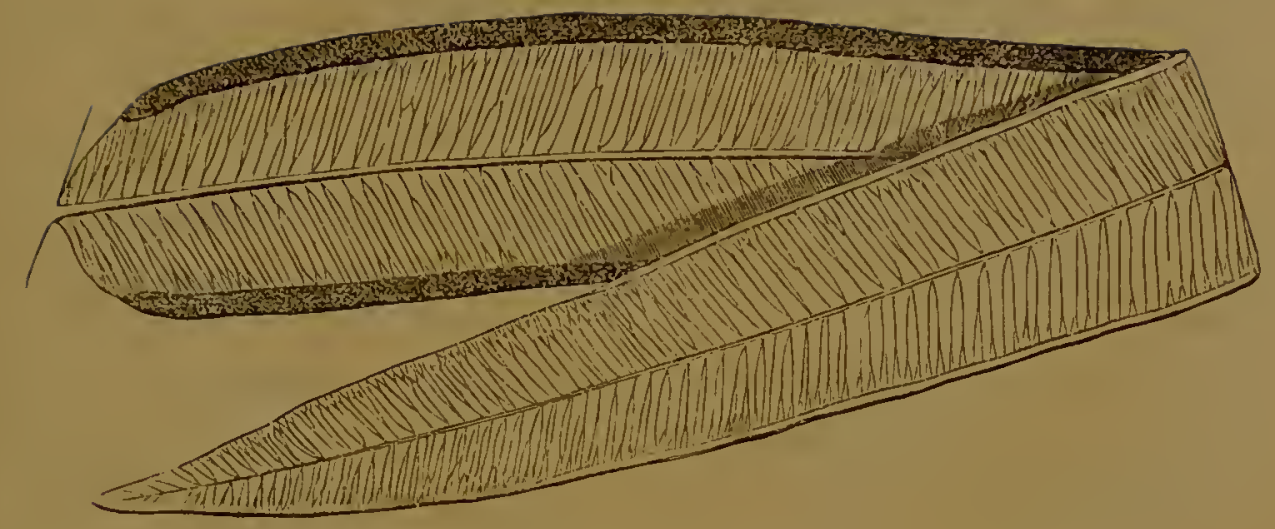

Pinna of mature Frond-under side.

\section{PTERIS GRANDIFOLIA.}

Linnaus. Plumier. Petiver. Slohane. Schinuhr. Kunze. Link. Presl, (not of Perpig, nor Scillechtendal.)

PLATE XIIX. VOL. III.

Litobrochia grandifulia, J. Smitir. Moore and Houlston. Heterophlebium grandifulium, FEE.

Pteris vittata, $\quad$ ScнкинR.

Pteris-Brake. Grandifolia-Large-leaved.

In tile Section Litobróchila of Authurs.

A LARGi, handsome species, seldom to be met with in eollections, and whose chief attraction is its boldness.

An evergreen stove Fern.

A native of the West Indies and Jamaica, St. Domingo, and Martinica.

Introduecd into England in the year 1793.

Fronds crect, pinnate; pinnic membranous, glabrous, petiolate, 
linear-aeuminate, abont one inels broad, and cighteen inclies long.

Raehis and stipes pubeseent, lateral, adherent to a erecping scaly rhizoma.

Sori linear, continuous, and very conspieuous.

Length of frond from eight to ten feet; colour pale green.

I have not yet been able to procure a plant of this species. My thanks are due to Mr. Henderson, of Wentworth, for fronds.

This rare and magnificent species is not yet to be proeured of any of our Nurserymen.

The illustration is from a frond forwarcled by Mr. Henderson, of Wentworth. 



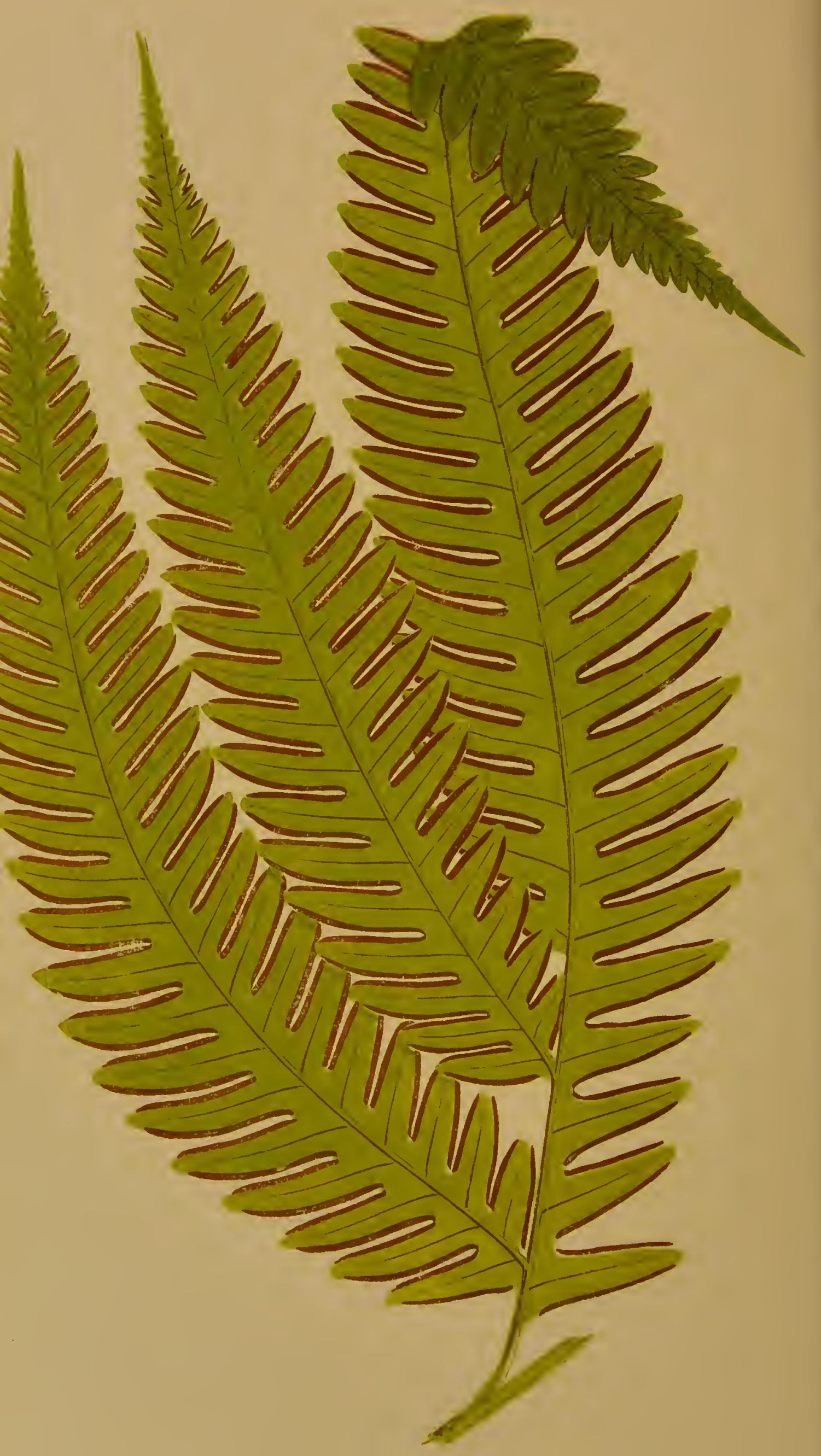





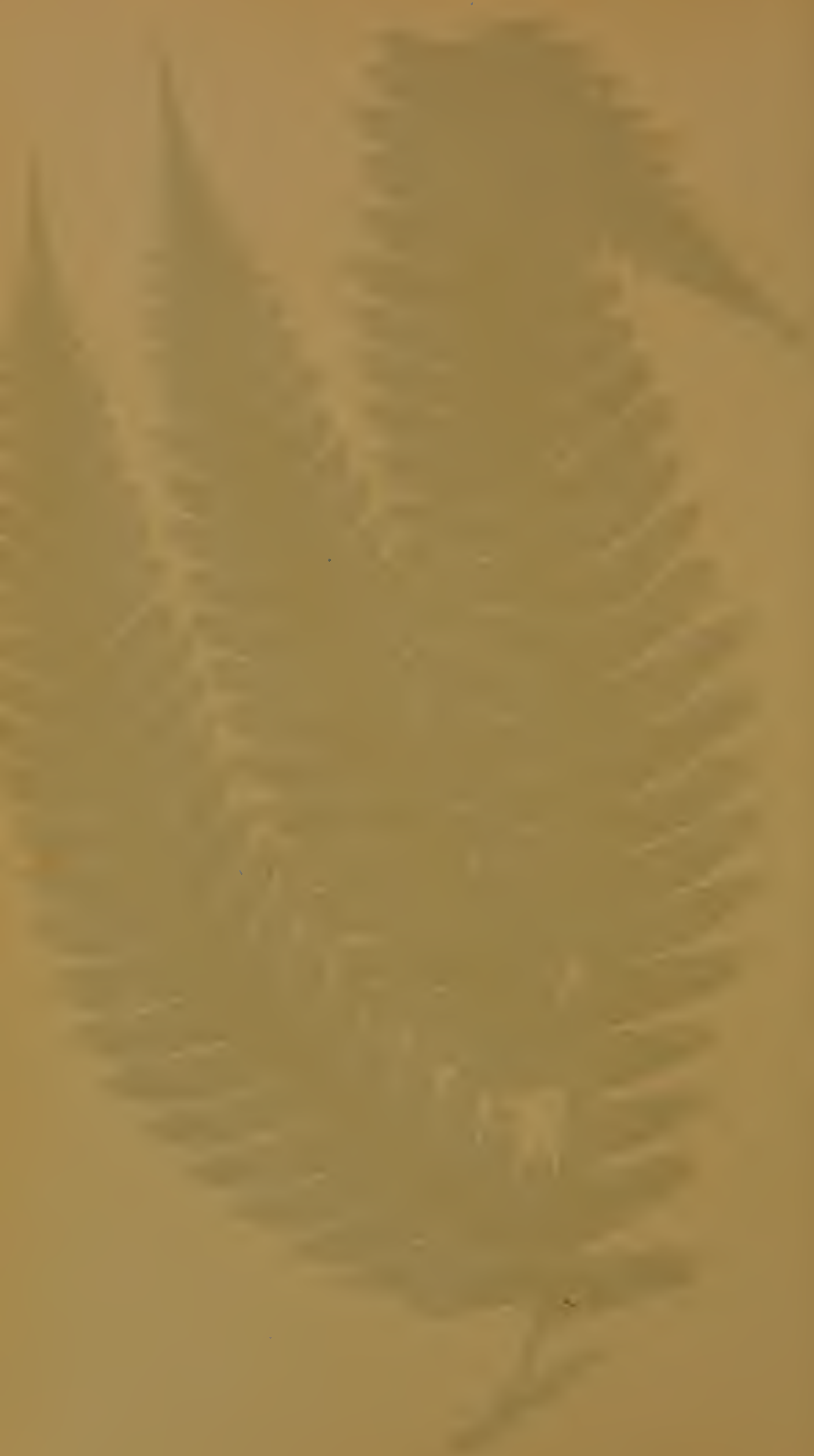




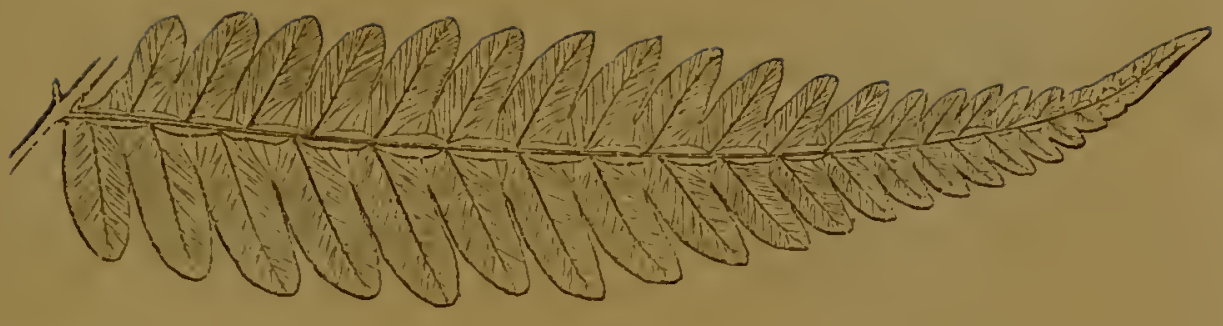

Portion of mature Fiond--upper side.

\section{PTERIS BIAURITA.}

\section{Linneus. Kunze. Plumier. Presl.}

Fee. Hooker and Bauer, (not of Sieber.)

PIATE L. VOI.. III.

Campleria biauritu, - J. Smitr. Moore and Hotlston.

Pleris nemoralis, $\quad$ Bluxis? (not of Willdenow.)

$$
\text { Pteris-Brake. Biaurita-Two-eared. }
$$

In the Section Canpteria of some Authors.

Some confusion exists as regarding what Fern is to be understood as representing the true Pteris biaurita, as it appears evident that several species bear this name. However there can be but little doubt but that the present Fern is that linown as $P$. biaurita of Linneus.

It is a handsome free-growing species, somewhat scarce in cultivation in England.

An erergreen stove species.

Native of the West Indies and Jamaica.

Introduced into the Royal Gardens, Kew, in 1842, by Mr. W. Purdie.

The fronds, which are glabrous, are triangularly elongate in 
their form, pinnate, and having lanccolate pinna, which are decply pinnatifid, petiolulate, with an entirc caudate apex. I.ower pair of pinne bipartite; segments linear, blunt, and sub-falcate.

Stipes slightly scaly near the base. Stipes half the length of the frond. 'Terminal, adherent to an crect fasciculate rhizoma.

Length of frond from threc to four feet; colour palc green.

My thanks are due to Mr. Thomas Moore, Curator of the Chelsea Botanic Gardens, for a plant of this specics; and to Miss Carr, of Qualt Rectory, for fcrtile fronds.

It appears to be only included in the Fern Catalogue of Messrs. A. Henderson, of Pine-apple Place.

The illustration is from a portion of Miss Carr's frond.

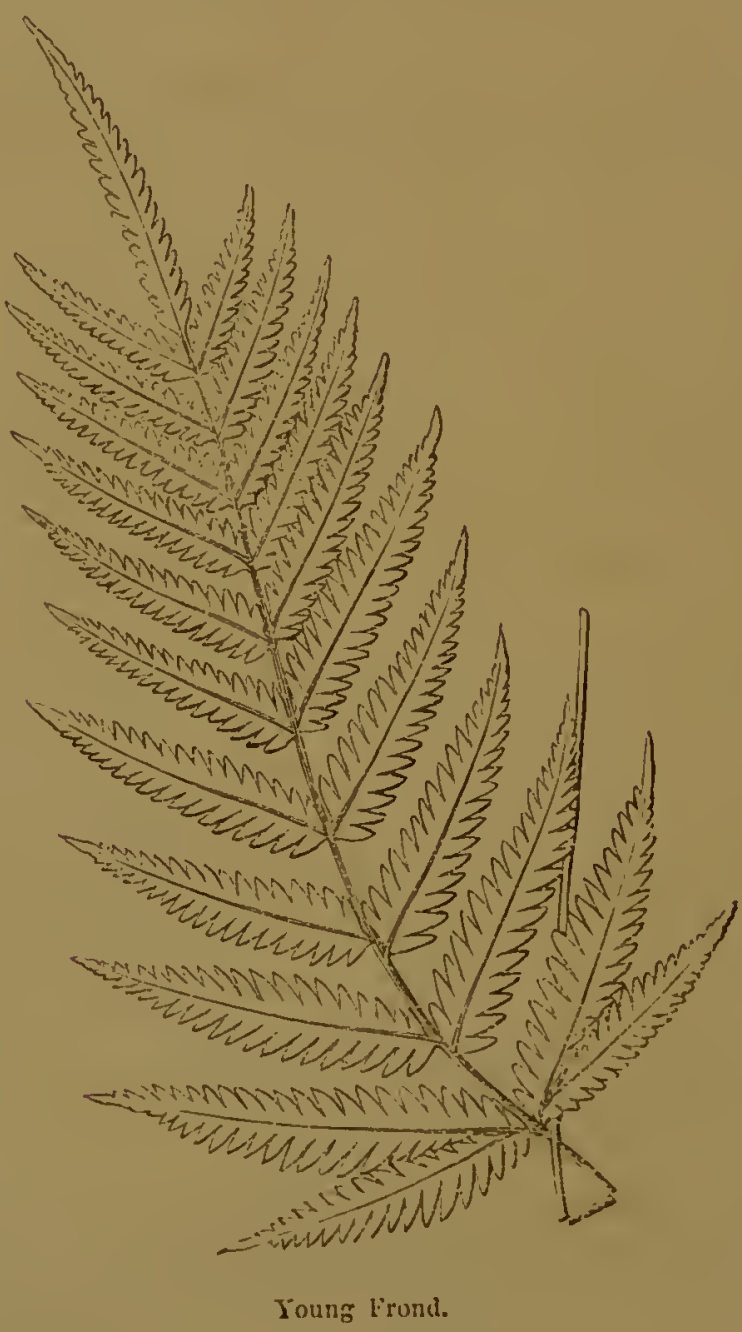




\section{GLOSSARY FOR VOL. III.}

[The present glossary contains descriptions of such terms as are not deseribed in that for Volume I. It must therefore be considered a continuation of that given at page 147 in the first Volume.]

Antrorsely. Having an upward dircetion towards the summit. Areoles. Having spaces distinctly marked out on the surface. Auricled. Eared.

Bitoled. Divided into two lobes.

Bipartite. Decply divided into two parts.

Cartilaginous. Substance tough or hard.

Chartaeeous. Thin, flexiblc, and membranous.

Continuous sori. When there is no breal from uniformity.

Cultriform. Knife-blade shaped.

Deeumbent. Reclining, but having a tendency to risc at the cxtremity. Deltoid. Somewhat triangular.

Digitate. Rescmbling fingers.

Flaecid. Weak or bending.

Glaueous. When the green colour has a peculiar whitish-blue lustrc.

Ineurved. Bending from without inwards.

Interrupted sori. Not continuous.

Murieato-scabrous. Rough, produced by short, hard, stiff pubcscence or scattered tubcrcles.

Orbicular. Circular.

Palmate. Hand-sliaped.

Pinnulets. Lcaflets.

Pilose. Hairy.

Plane. Perfectly levcl or flat.

Retieulated. Resembling net-work.

Reflected. Turncd back.

Sagittate. Arrow-shaped.

Seabrous. Rough.

Squamiferous. Covered with scales.

Subhastute. Nearly halbert-shaped.

Subterrancously. When the rhizoma crecps underground.

Sultritobate. Nearly divided into three lobes.

Trapezoid. When the sides of a four-sided leaf are uncqual.

Trilobate. Divided into threc lobes.

Trilobed. Dirided into three lobes.

VOL. III. 


\section{AUTHORITIES QUOTED IN VOL. III.}

Agardl.

Aiton.

Arnott.

Arrab.

Babington.

Bauer.

Bernlardi.

Blume.

Bolton.

Bompland.

Bory.

Bredemeyer.

Brown, R.

Burmann.

Cameron, D.

Cantor, Dr.

Cavanilles.

Chamisso.

Chapman.

Colenso.

Cumuingham, Allan.

\section{Deakin.}

Desvaux.

Don.

Edgerley, G.

Endlieher.

Fce.

Fiseher.

Forskahl.

Forster.

Franeis.

Galleotti.

Gardner, G.

Gaudiehaud.

Gmelin.

Gray, A.

Greville.

IIenderson, J.
Hoftmau.

Hooker, Dr. J. D.

Hooker, Sir W. J.

Houlston.

Hputtuyn.

IIumboldt.

Jacquin.

Kaulfuss.

Klotzsch.

Kunth.

Kunze.

Labillardiere.

Lamarck.

Langsdorff.

Le Prieur.

Leph.

Linden.

Link.

Linnæus.

L'Herminier.

L'Hermonnier.

Loddiges.

Loudon.

Lowe, E. J.

Lowe, Rev. H.

Mrekay.

Martens.

Martius.

Me'William, Dr.

Miguel.

Moore, Thomas.

Moricaud.

Newman.

Petirer.

Plunkenet.

Plumier.

Poppig.

Poiret.
Pratt.

Presl.

Purdic.

Raddi.

Raoul.

Retzius.

Rheed.

Riehard.

Rupprecht.

Salisbury.

Sehkuhr.

Sehleehtendal.

Schomburgk, Sir R. II.

Schott.

Sehrader.

Seeman.

Sieber.

Sinclair, Dr.

Skinner.

Sloane.

Smith, J.

Sowerby.

Splitzgerb.

Sprengel.

Spruee, $R$.

Stokes.

Swartz.

Tauseh.

Thunburg.

Tournefort.

Vahl.

Villars.

Wrallieh.

Webb.

Willdenow.

TVilson.

Wollaston. 
Adiantum flagelliferum . $\quad . \quad 5$

faleatum . . . 57

fontanum . . . 39

flabellulatum . . 58

formosum. R. Brown . 29

$30,31,59$

formosissima . . . 27

formosissinum . . 9

fovearum . . . 51

fragile. $\cdot$. 58

fruetuosum $\quad \cdot \quad 4.7,52,57$

fulvum. Raoul $31,49,59$

fumarioides . . $\quad 58$

galleottianum . $\quad \cdot 57$

giganteum $\cdot \quad \cdot \quad=29$

glauceseens. • . 57

glaueophyllum . . 58

hænkeanum. . . $5 \pi$

liastatum . . . 87

henslorianum . . 59

hewardia . . . 56

hirtum . . . 40

lirsutum . . . 5

hispidulum. Swartz 25, 33,

34,58

humile $\quad \cdot \quad 18,58$

incisunı . . . 5,57

intermedium. Swart 51 ,

$55,57,59$

kaulfussii . . . 56

klotzschianum . . 9,57

kunzianum . . . 45

laneca. . . $\quad 58$

laxum . . . . 57

le prieurii . . . $\quad 58$

lindsca . . . . 58

lobatum . . $\quad . \quad 57$

lobbianum . . . 59

lucidum. Irookcr 11, 35, 56

lunatum . . . . 23

lunulatum. Burmann $2: 3$,

21,57

macroeladum $\quad \cdot \quad$. 59

macrophyllum. Swair/z 18 , 56

mathensianun $\quad \cdot \quad \cdot 58$

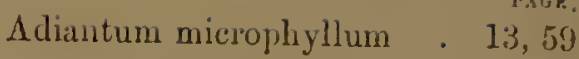

monosoratum . . 45

moritzianum $\quad \cdot \quad 39,41$

obliquum. Willdenow 35,57

obtusum . . . 57

papyraceum · . 59

paradoxus . . . 79

parvulum . . . 59

patens . . . . 58

pedatum. Linnous $\quad 1,25$,

37,58

pentadactylon $\quad \cdot \quad 9,53$

peruvianum . . . 58

pliilippense $\quad . \quad 8,56$

phyllitidis • : . 56

platyphyllum . . 56

plieatum . . . 25

poppigianum · · 11

politum . . . . 59

polyphyllum $\quad \cdot \quad \cdot 59$

prionophyllum $\quad \cdot \quad 52,57$

proximum . • • 58

pteridioides . . . 11

pubescens. Schkukv 25, 29,

33,34

pulehellum $\quad$ • $\quad 58$

pulverulentum. Linn. 45,57

pumilum • • • 57

pyramidale . • . 59

reniforme. Linncus $\quad 7,56$

repandum · • $\quad 39$

rhizophorum $\cdot \quad \cdot 57$

rhizoplytum . . . 57

rhomboideum $\quad \cdot \quad 9,57$

rigidum . . . . 45

rotundatum . $\quad$. 59

ruizianum . . . 57

seabrum . . . 58

secmanni $\cdot \cdot \quad \cdot 56$

serrulatum $\quad . \quad .5 j, 5 \pi$

sessilifolium . • . $5 s$

setulosum $\quad \cdot \quad 19,31$

shepherdi $\quad \cdot \quad \cdot \quad 57$

sinuosum $\cdot \cdot \cdot 5^{2}$

soboliferum · . $\quad .57$

speciosum $\quad . \quad 5 ?$ 
Adiantum striatum . $\quad$. $\quad 13,55$ subcordatum . . 58 sulphureum . . . 58 tenerum. Swart $\approx 3,27,28$, $29,39,59$ tetragonum . . 18, 58 tetraphyllum . . 47 trapeziforme. Linnaus 9, $10,19,53,58$ triangulatum $\quad \cdot \quad 51,52,57$ trifidum . . . 39 trigonum . . . 21 umbrosum . . . 45 uropliyllum ' . 57 varium. Hooker 47, 48, 51, 55,57

venustum . . $\quad .58$ vestitum . . . 5 villosum $46,47,48,51,55,57$ wilesianum . . . 59 wilsoni. Hooker . 43,56 Allosorus acrostichoides . . 91 adiantoides $\quad$ • 89 atropurpureus $\quad \cdot \quad$. 81 brunonianus . . 91 calomelanos . . . 73 chærophyllum . • 61 ciliatus . . . . 91 crispus. Bernlıardi 65, 91, $93,94,95$ crispidatus . . 61 falcatus $\quad . \quad \cdot \quad .83$ flexuosus . . . 71 gracilis $\quad . \quad \cdot \quad .91$ hastatus . . . 87 hirsutus . . . 91 intramarginalis $\quad \cdot \quad 85$ paradoxus . . . 79 robustum . . . 61 rotundifolius $\quad . \quad .67$ sagittatus . . $\cdot 77$ stelleri . . . . 93 subverticillatus $\quad . \quad 69$ ternifolius . . . 69 Anemia fraxinifolia $\quad \cdot \quad \cdot 97$ Canptcria biaurita . . . 133
Page.

Cassebeera hastata . . $\quad 87$ inframarginalis . . 85

Cheilantlıes gracilis . . . 91 hastata . . 87 lucida . . . 63 spinulosa . . . 127

Cryptogramma brunonianus 91 crispa . . . 93

Doryoptcris articulata . . 97 collina. J. Smith 97, 100, 105 cordifolia . . . 97 hastata . . . . 97 hastifolia, var. . . 101 palmata. J. Smith 97, 99, $100,103,105$ pedata. Fee 76, 97, 99, $\begin{array}{rr} & 103,105 \\ \text { preal ta } \quad . \quad . \quad 97\end{array}$ raddiana . . . 97 sagittæfolia. J. Smith 101 sagittifolia $\quad . \quad 97,101$ trifoliata . . . 97 varians $\cdot \quad \cdot \quad .97,105$ wallichii . . . 97

Filix latifolia . . . . 117

Hewardia wilsoni . • 43

Heterophlebium grandifolium 131

Hypolepis repens · • . 123

Leptostegia lucida $\quad$ • $\quad 63$

Litobrochia biaurita . . 133 grandifolia $\quad \cdot \quad \cdot 131$

leptophylla . . . 127 pedata $\quad \cdot \quad .97,99$ sagittæfolia . . . 101 vespertilionis $\quad \cdot \quad \cdot 121$

Lomaria carvifolium _. . 61

Nephrodium molle • . 123

Onoclea crispa $\quad \cdot \quad \cdot \quad \cdot 93$

Onychium auratum $\quad \cdot \quad \cdot \quad 61$ capense $\quad \cdot \quad \cdot 61$

carvifolium $\quad \cdot \quad \cdot 61$ chærophyllum . . 61 chinense • • . 61 japonicum . . 61, 63 lucidum. Sprengel 61,63 melanolepis $\quad$. 61 


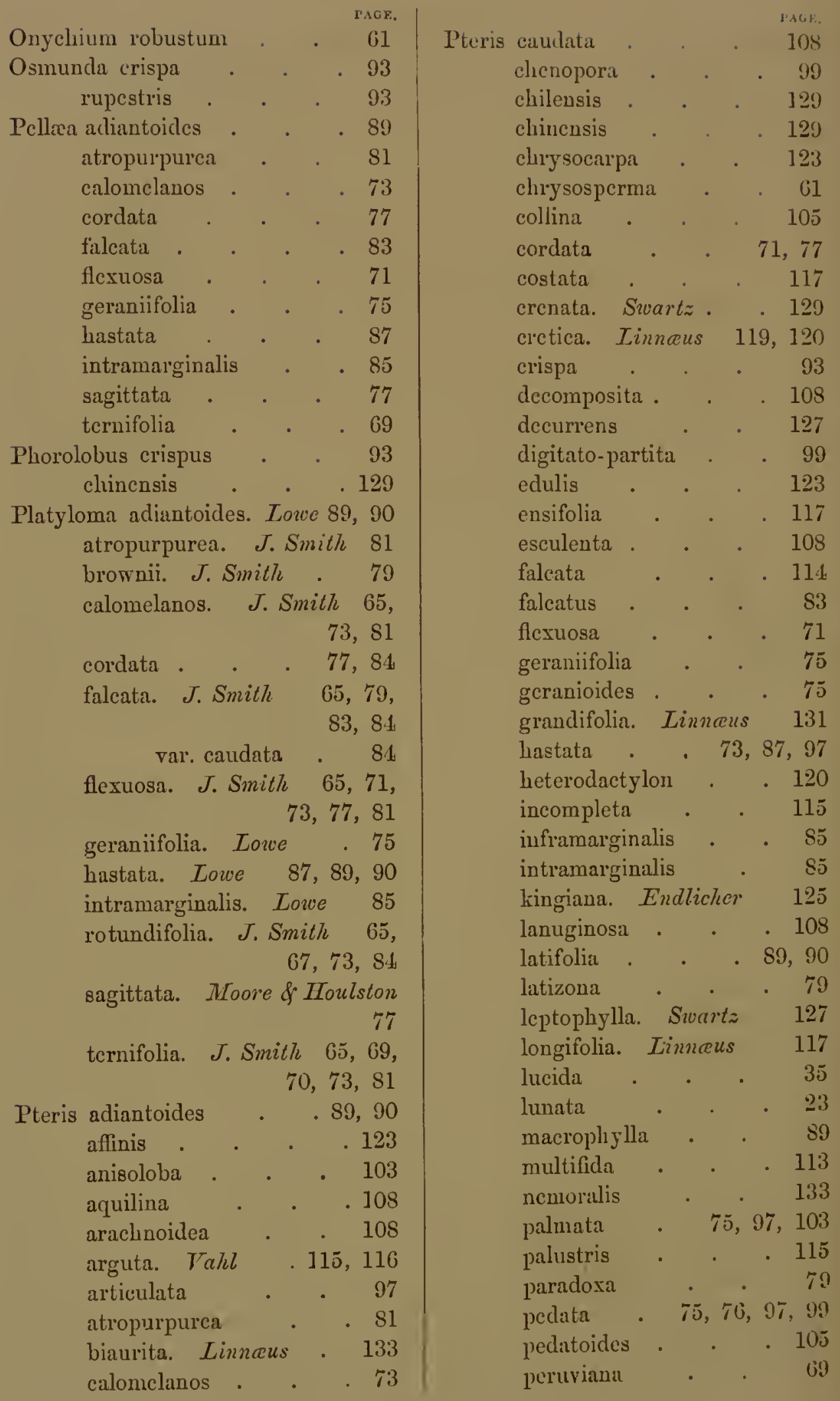


INDEX.

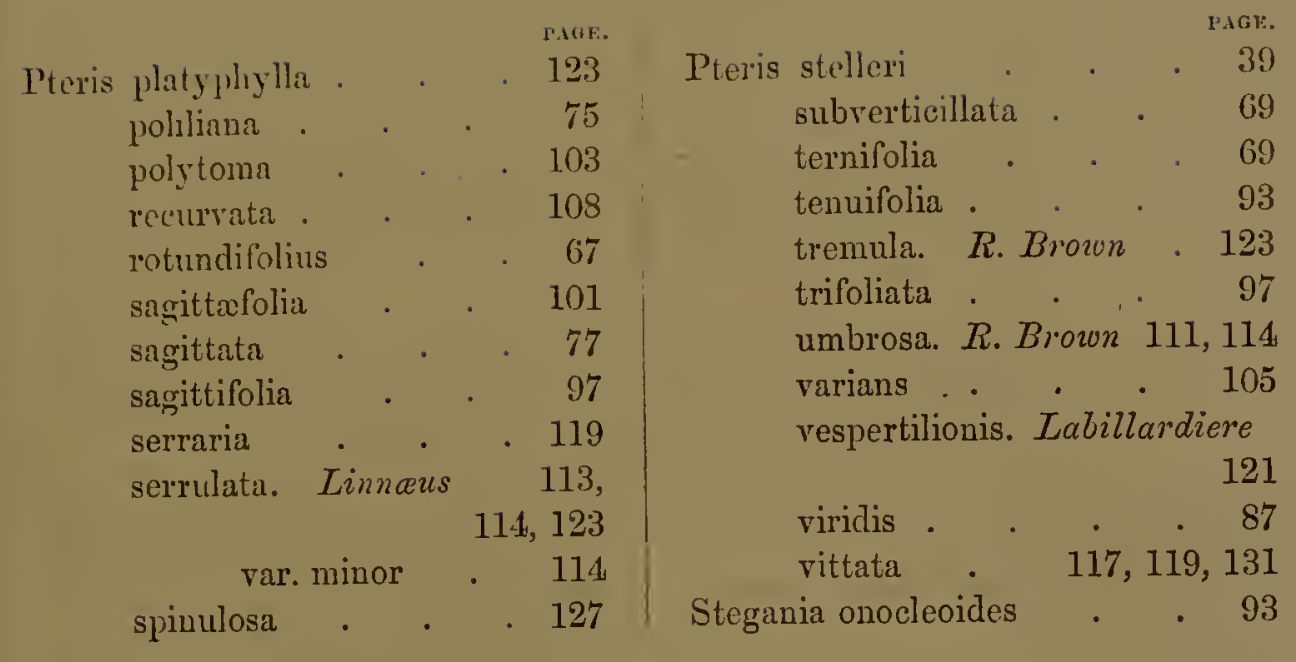




\section{CONTRIBUTORS TO 'VOL. III.}

ThE Author begs to thank the following individuals, who have kindly supplied plants and fronds for illustration:-

Mr. G. H. Alleoek, Nottingham.

Mr. Baekhouse, York.

Miss Barker, Trent Loek, Beeston, near Nottingham.

Mr. Booker, Matlock.

Messrs. Booth and Son, Nurserymen, Hamburg.

Miss Carr, Qualt Reetory, near Bridgnorth, Salop.

Mr. Clarke, Royal Botanic Gardens, Glasgow.

Mr. Robert Clark, gardener to W. Dent, Esq., Flass House, Crosby Ravensworth, Westmorland.

Mr. Downs, Hillsboro' Terraee, Tifracombe.

Mr. R. J. Grey, St. Thomas', Exeter.

Mr. Haythorn, Wollaton Hall, Notts.

Messrs. A. Henderson \& Co., Nurserymen, Pine-apple Plaee, Edgeware Road, London.

Messrs. E. G. Henderson, Wellington Nursery, St. John's Wood, London.

Mr. Joseph Henderson, Wentworth House, Yorkshire.

Dr. J. D. Hooker, F.R.S., Royal Gardens, Ker.

Mr. Ingram, Royal Gardens, Windsor.

Mr. Ingram, Belton, ncar Grantham.

Mr. Ingram, Belvoir Castle, near Grantham.

Mr. J. W. Jeans, F.R.A.S., Grantham.

Mr. Jaekson, Keddleston Gardens, near Derby.

Mr. James, Vauvert, Guernsey.

Mr. Iamb, gardener to F. Wright, Esq., Osinaston Manor, near Ashbourne.

Mr. R. T. Millett, Penzance.
Captain A. S. H. Lorre, F.R.A.S, High field House, near Nottingham.

Mr. Masters, Exotic Nursery, Canterbury.

Mr. Thomas Moore, F.L.S., Curator of the Chelsea Botanie Gardens.

Sir Oswald Mosley, Bart., Rolleston Hall, near Burton-on-Trent.

Mr. G. Norman, Hull.

Messrs. Parker, Nursery, Holloway.

Mr. Pass, gardener to T. Brocklehurst, Esq, The Fenee, near Macelesfield.

Mrs. Riley, Papplenick, near Nottiugham.

The Rev. J. Robinson, Widmerpool, Notts.

Messis. Rollisson \& Co., Nursery, Tooting, near London.

Mr. Roper, Brighton.

M. Sehott, Director of the Imperial Gardens, Schonbrünn, near Vienna.

Mr. J. Smith, Curator of the Royal Gardens, Ker.

Mr. J. Sidebotham, Manehester.

Mr. R. Sim, Foot's Cray Nursery, near Chisselhurst, Kent.

Mr. Stansfield, Vale Nursery, Todmorden.

Mr. Stewart, Sudbury Castle, Staffordshirc.

Mr. Stratton, Botanic Gardens, Cambridge.

Messis. Veitch, Exotie Nursery, Exeter.

Messrs. Veiteh, Jun., Exotic Nursery, Chelsea.

Mr. G. I3. Wollaston, Chisselhurst, Kicnt.

Mr. Wraight, Nerrlands, Kent.

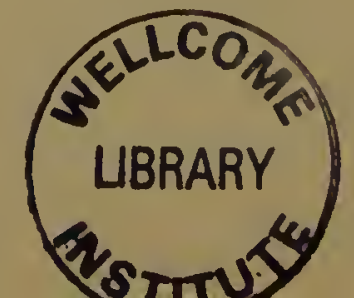






